\title{
«Operasjon asfalt»
}

Kald krig om krigsgraver 

Marianne Neerland Soleim

\section{«Operasjon asfalt»}

Kald krig om krigsgraver

Orkana Akademisk 


\section{Marianne Neerland Soleim (C) 2019 \\ "Operasjon asfalt» \\ Kald krig om krigsgraver}

This book is published as Open Access under the copyright regulations of Creative Commons License CC-BY 4.0.

Creative Commons License CC-BY 4.0 gives permission to copy and distribute the work in any medium or format, partially or fully, and to freely use the material for any purpose. Correct references to the work and authors must be applied, and include reference to the license, together with a specification of whether changes have been made. Reference to the original work can be provided in any reasonable manner, but can not suggest that the authors or the publisher endorse the third party or the third party's use of the work. Any reuse of the material in this book may not infringe upon the rights of reuse by other parties.

For a full description of the Creative Commons License CC-BY 4.0 consult the following webpage: https://creativecommons.org/licenses/by/4.o/legalcode

PDF: ISBN 978-82-8104-372-5

EPUB: ISBN 978-82-8104-373-2

HTML: ISBN 978-82-8104-374-9

XML: ISBN 978-82-8104-375-6

DOI: https://doi.org/10.33673/OOA20192

Forfatteren har mottatt støtte til sitt arbeid fra Norsk faglitterær forfatter- og oversetterforening. Boka er utgitt med støtte fra Stiftelsen Fritt Ord, HSL-fakultetet ved UiT Norges arktiske universitet, Falstadsenteret og Norsk kulturfond.

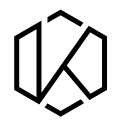

NORSK

KULTURFOND

Kulturrådet

Forside: Tyske soldater graver fram sine ofre for flytting til annen gravplass.

Foto: Arne Langvik-Hansens arkiv / Rana Museum.

Omslagsillustrasjonen er ikke omfattet av Creative Commons-lisensen.

Omslagsdesign: InDevelop

Sats: InDevelop

Opprinnelig utgave Orkana Akademisk 2016

Orkana forlag as, 8340 Stamsund

ISBN 978-82-8104-278-0

www.orkana.no

post@orkana.no 


\section{Innhold}

$\begin{array}{ll}\text { Innledning } & 7\end{array}$

1. Oppgraving og samling av krigsgraver før «Operasjon asfalt» $\quad 14$

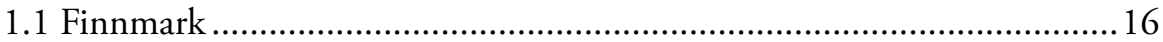

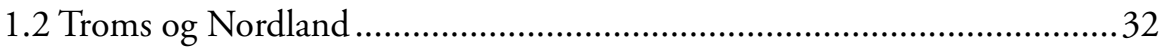

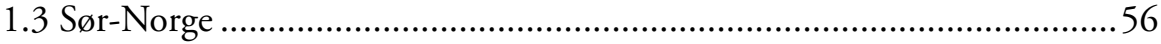

2. Diplomatisk dragkamp og norsk-sovjetisk krigsfangekommisjon 77

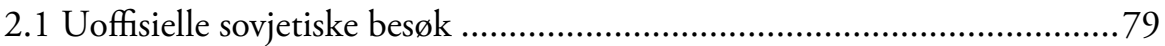

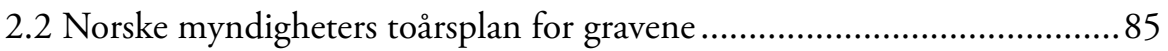

2.3 Alternativer til løsning av gravspørsmålet .............................................90

3. «Operasjon asfalt» 96

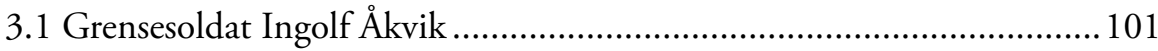

3.2 Planlegging av transport til Tjøtta krigskirkegård ..................................104

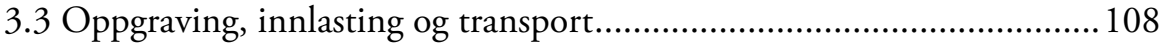

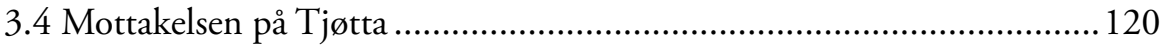

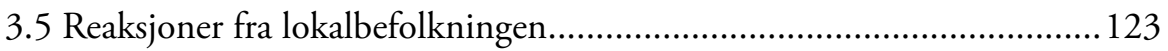

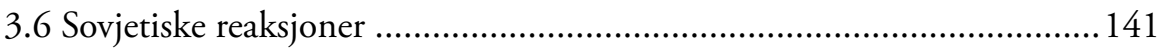

4. Den norsk-sovjetiske gravkommisjonen 149

4.1 Gravkommisjonens mandat og diskusjon om antallet minnesmerker....149

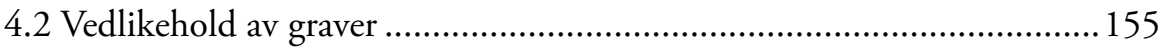

4.3 Gravkommisjonens reise til Nord-Norge ............................................. 157

4.4 Gravkommisjonen og ny flytting av graver i Sør-Norge ......................... 160

5. Likfunn etter «Operasjon asfalt» 167

6. Identifikasjon av sovjetiske ofre 173

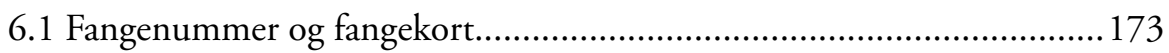

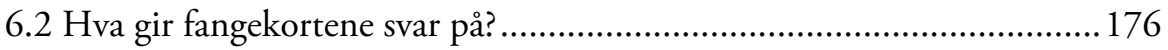

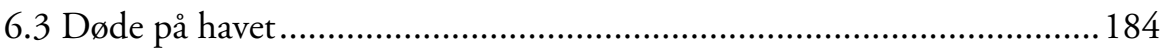

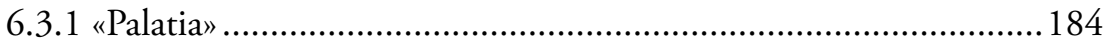

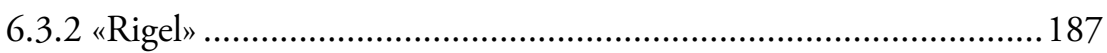




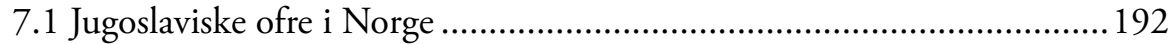

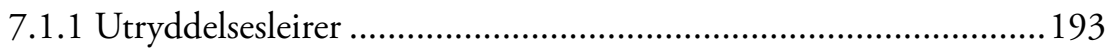

7.1.2 Norsk hjelp og fanger på flukt..................................................201

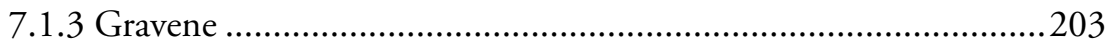

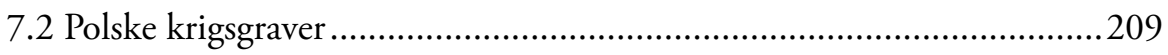

8. Minnet om de døde 211

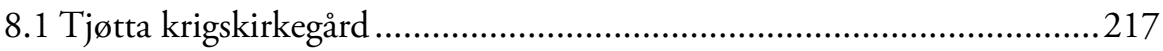

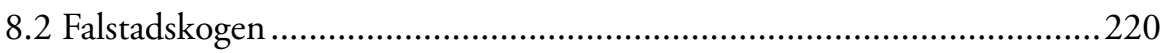

8.3 Jørstadmoen sovjetiske krigskirkegård .................................................229

8.4 Østeuropeiske ofre i dagens minnekultur i Europa .................................232

Avslutning 239

Kilder $\quad 245$ 


\section{Innledning}

Dette er historien om sovjetiske krigsfanger og soldater som mistet livet i Norge under andre verdenskrig. Den beskriver årsakene til at sovjetiske krigsfanger døde, de første samlingene av gravene kort tid etter frigjøringen, det norsk-russiske samarbeidet angående gravene, gjennomføring av «Operasjon asfalt» samt reaksjonene fra lokalsamfunn og andre tilknyttet arbeidet med operasjonen. Likfunn etter 1950-tallet og arbeidet med identifikasjonen av de sovjetiske ofrene i nyere tid er beskrevet. I bokens siste del er forvaltningen omkring jugoslaviske og polske krigsgraver i etterkrigsårene i regi av norske myndigheter, og hva som har preget minnekulturen knyttet til de østeuropeiske ofrene etter andre verdenskrig, beskrevet. Tyngdepunktet i boken er lagt på de sovjetiske ofrene for tysk brutalitet i Norge.

Dødsfall blant krigsfangene under den tyske tilbaketrekningen fra Finnmark og krigsforbrytelser knyttet til fangeleirene som ble etablert under tilbaketrekningen, ble svært vanskelig å kartlegge etter frigjøringen. Sogneprester og lensmenn over hele landet fikk en komplisert jobb med å registrere opplysninger om sovjetiske krigsgraver i 1945. De fikk også ansvaret for å foreta nødvendig flytting og samling av alle utenlandske graver i eget distrikt. Mange steder ble ofrene flyttet flere ganger i tiden mellom frigjøringen og 1951. En tysk gravekommando ble satt inn i arbeidet med oppgraving av sovjetiske ofre i Nordland i 1946, men registreringene som ble gjort i denne tidlige fasen, ga en svært dårlig oversikt over antallet gravlagte. I tillegg til dette hadde norske myndigheter svært lite informasjon om de sovjetiske krigsfangene som døde i Finnmark og Troms. Mesteparten av informasjonen var basert på uklare vitnebeskrivelser og et fåtall identifikasjonsmerker som ble funnet på ofrene. På 
de fleste stedene i disse to fylkene var det sjelden mulig å få avklart de døde krigsfangenes personopplysninger eller fangenummer.

Få år etter at de overlevende krigsfangene var sendt hjem, ble de sovjetiske ofrene for den tyske okkupasjonsmakten et sentralt tema i norsk offentlighet i 1951. Den norske regjeringen ønsket da å flytte levninger etter døde sovjetiske krigsfanger fra Finnmark, Troms og Nordland til Tjøtta krigskirkegård på Helgelandskysten utenfor Sandnessjøen. Arbeidet med flyttingen fikk trolig dekknavnet «Operasjon asfalt» fordi de oppgravde likene ble fraktet i asfaltsekker. Planleggingen av «Operasjon asfalt» startet i 1948 med sikte på å etablere et felles gravsted på Tjøtta. ${ }^{1}$

Fra sovjetisk side ble Tjøtta betraktet som et isolert og avsidesliggende sted. Men dette ble avvist av norske myndigheter, som mente at stedet var langt lettere tilgjengelig enn det store flertall av de gravene som nå ble flyttet dit. De mente det var en fordel for pårørende, tidligere medfanger fra krigsfangenskapet eller for andre sovjetborgere som ønsket å besøke gravene, at de ble samlet. Norske myndigheters oppfatning var at Tjøtta ville fungere godt som en sentral gravplass for alle de sovjetiske borgerne som mistet livet i Nord-Norge.

Totalt omfattet «Operasjon asfalt» ca. 200 gravplasser hvorav $95 \mathrm{i}$ de tre nordligste fylkene. ${ }^{2}$ Flyttingen av de sovjetiske krigsfangene ble fullført i 1951. På krigskirkegården på Tjøtta er det ifølge opplysninger fra Krigsgravtjenesten ved Eugen Syvertsen gravlagt i alt 7453 sovjetiske soldater. ${ }^{3}$ I ettertid er flere ofre blitt gravlagt på Tjøtta. I 1952 opplyste Utenriksdepartementet at det var overført 8804 døde til Tjøtta, hvorav 978 var identifisert. Det var tydeligvis vanskelig å få fastsatt et eksakt tallmateriale etter at flyttingen var gjennomført, tallmaterialet som Utenriksdepartementet oppga i 1952, stemmer ikke med det som er oppgitt på monumentet på Tjøtta. På monumentet er det oppgitt 6725 ukjente og 826 navngitte gravlagte.

«Operasjon asfalt» omfattet ikke gravene til falne sovjetiske soldater som hadde mistet livet i kamper med tyske styrker på norsk jord i operasjonen Petsamo-Kirkenes i oktober 1944. I virkeligheten dreide det seg stort sett om gravene til sovjetiske soldater som ble ført som krigsfanger til Norge i løpet av 1941-1945. I hovedsak var det bare i Sør-Varanger at sovjetiske soldater falt i kamp i Norge. Levningene etter disse falne sovjetiske soldatene ble ikke gravlagt på Tjøtta, men sendt til Sovjetunionen og gravlagt der i etterkrigsårene.

$1 \quad$ Jf. Eriksen, Knut Einar og Pharo, Helge Øystein: Kald krig og internasjonalisering 1949_ 1965. Norsk utenrikspolitikks historie. Bd. 5. Universitetsforlaget, Oslo 1997: 425.

2 RA, Krigsgravtjenesten, eske 26, sovjetiske krigsgraver 1946-1952.

3 RA, Krigsgravtjenesten/eske 28 1942-1960. «Opplysninger om den sovjetiske krigskirkegård på Tjøtta», februar 1960. Det tidligere registrerte antallet gravlagte sovjetiske borgere er i alt 8710. Det antallet som er oppgravet og overflyttet til Tjøtta, er 7826. Jf. RA, Krigsgravtjenesten eske 26-35. Rapport, «til Det kongelige forsvarsdepartement, fra Hærens overkommando/Sentralkontoret for krigsgraver», Oslo, Frognerleiren, 15.12.1951. 
Flyttingen av sovjetiske krigsgraver var nær knyttet til den kalde krigens politikk og norske myndigheters frykt for sovjetisk spionasje var et hovedmotiv for gjennomføringen av den. «Operasjon asfalt» inntraff under Koreakrigen, da det internasjonale spenningsnivået ble dramatisk forverret. Befolkningen i Nord-Norge ga uttrykk for forskrekkelse og sinne under gjennomføringen av operasjonen. Makabre detaljer om oppgravingen av sovjetiske ofre ble publisert i mange aviser, og folk demonstrerte flere steder i protest mot flyttingen av gravene. ${ }^{4}$ Planene, gjennomføringen og reaksjonene i ettertid knyttet til operasjonen gir inntrykk av at militære og statlige norske myndigheter hadde for mye hastverk og ikke hadde regnet med det store engasjementet blant befolkningen.

Et par år etter at "Operasjon asfalt» var gjennomført, ble også jugoslaviske og polske døde krigsfanger gravd opp og flyttet til egne kirkegårder her i landet, men oppgravingen og flyttingen av disse ofrene fikk ikke den samme negative oppmerksomheten i norsk offentlighet. Utformingen av minnesmerkene over de polske ofrene ble diskutert i norske medier, men denne debatten gjaldt symboler som tilhørte det kommunistiske regimet i Polen og ikke selve flyttingen av de polske gravene i Norge.

I nyere tid har "Operasjon asfalt» tidvis fătt oppmerksomhet i den bredere offentlighet. Det ble ikke noen nasjonal debatt om norske myndigheters behandling av sovjetiske krigsgraver da en radiodokumentar tok opp temaet i 1996. Operasjonen ble også beskrevet i 1999 i artikkelen «Kirkegårdskrigen i 1951» i Arbok for Rana 1999, skrevet av Thor Helge Eidsaune. ${ }^{5}$ Han ga et innblikk i den unike massemobiliseringen i protestene mot flyttingen av sovjetiske graver i Mo i Rana. I Norsk utenrikspolitisk historie blir krigsgravsaken omtalt som bisarr, og utpekes som en av flere spesifikke bilaterale kontroverser som bidro til å forsure og begrense forbindelsene mellom Norge og Sovjetunionen. ${ }^{6}$ Forholdene omkring «Operasjon asfalt» har også vært omtalt i media i nyere tid. På spørsmål om russerne ønsket å bruke gravstedene som påskudd for spionasje, uttalte historiker Torgrim Titlestad at det neppe var noe seriøst motiv for sovjetiske myndigheter å hedre soldatene tatt i betraktning hvordan de behandlet krigsfangene som returnerte til Sovjet. Men han karakteriserte samtidig oppgravingen som både makaber og morbid. Overfor Sovjet kunne en markere norsk suverenitet, men ikke overfor USA. En ga mer eller mindre blaffen i folkemeninga i nord.?

4 En rekke artikler og innlegg om demonstrasjoner og protester ble publisert i avisene Verdens Gang, Nordland Arbeiderblad, Nordlands Folkeblad og Friheten i september/ oktober 1951.

5 Eidsaune, Thor Helge: «Kirkegårdskrigen 1951», i Årbok for Rana. Mo i Rana 1999.

6 Eriksen, Knut Einar og Pharo, Helge Øystein: Kald krig og internasjonalisering 1949_ 1965. Norsk utenrikspolitikks historie. Bd. 5. Universitetsforlaget, Oslo 1997: 63.

7 Dag og Tid, 24.02.2000. 
Debatten om sovjetiske krigsgraver på nasjonalt nivå kom først i 2008, etter at myndighetene i 2002 hadde fjernet navneplatene til 826 enkeltgraver på den sovjetiske krigskirkegården på Tjøtta i Helgeland. Etter mye press fra regionale og lokale myndigheter ble navneplatene til slutt lagt tilbake på kirkegården i november 2008. Det siste bidraget som skildrer «Operasjon asfalt» basert på tidsvitners fortellinger, er Halvor Fjermeros' bok Med lik $i$ lasten. Operasjon Asfalt-de sovjetiske massegravenes skjebne i Norge (2013). ${ }^{8}$ Boken beskriver opplevelsene til noen av mannskapet om bord på skipene som fraktet de sovjetiske ofrene fra gravsteder i Nord-Norge til Tjøtta og ikke minst hvilke påkjenninger dette arbeidet medførte for dem som var med.

For etterkommerne av ofrene fra det tidligere Sovjetunionen betyr det mye å få vite hva som skjedde med slektningene deres i Norge i krigsårene. De leter etter svar på hvor en bror, far, bestefar eller onkel ligger gravlagt, og $ø$ nsker å vite om gravstedene blir tatt vare på. Det er fastlagt egne internasjonale regler i 3. Genèvekonvensjonen av 12. august 1949 artikkel 120 for å ta vare på informasjon om døde soldater og krigsfanger i krig. Konvensjonen fastsetter de enkelte lands forpliktelser til å ta vare på andre nasjoners krigsgraver etter krigsslutt. Norske myndigheters oppfatning av konvensjonen var likevel at den ikke uten videre kunne brukes i fredstid, men omfattet de stridende parter i en krig. Denne holdningen har nok svekket norske myndigheters forståelse av hvilket ansvar de har for å ta vare på sovjetiske krigsgraver i Norge. De sovjetiske krigskirkegårdene i Norge er underlagt varig vern ifølge internasjonale konvensjoner. Krigskirkegårdene er underlagt Genèvekonvensjonen av 1949 og administreres av enheten Krigsgravtjenesten i Kultur- og kirkedepartementet. Funn av graver og levninger vekker til dels sterke følelser hos de fleste, og jo nærmere slike funn er vår egen tid, desto sterkere vil følelsene være. ${ }^{9}$

Både ved nye funn av graver og spørsmål knyttet til merking og vedlikehold av krigsgraver er Norge forpliktet til å følge internasjonale regler. Norske myndigheter har innhentet informasjon fra andre land for å få avklart hvordan de skulle forholde seg til utenlandske nasjonaliteters krigsgraver. Krigsgravtjenesten har ansvar for merking og vedlikehold av krigsgraver, registrering av utenlandske falne krigsmenn i Norge og oppsporing av norske falne som er gravlagt i utlandet. Etter andre verdenskrig ble landene som hadde skrevet under Genèvekonvensjonene av 12. august 1949 pålagt å følge reglene i konvensjonene om gravlegging av utenlandske falne. Gravene skulle merkes og vedlikeholdes etter regler i konvensjonene. Gravene skulle også gjøres til-

8 Fjermeros, Halvor: Med lik i lasten. Operasjon Asfalt - de sovjetiske massegravenes skjebne $i$ Norge. Spartacus, Oslo 2013.

9 Sellevold, Berit J.: NIKU Rapport 32. «Om retningslinjer for håndtering og forvaltning av skjelett- og gravfunn fra nyere tid». Rapport til Riksantikvaren. Oslo 2009: 14-21. 
gjengelige for besøkende. Norske myndigheters oppfatning var at bestemmelsene i konvensjonene gjaldt mellom de stridende parter under en krig, og at den ikke uten videre kunne brukes under fredelige forhold mellom allierte. Hensikten med bestemmelsen var ikke å gi den ene parten rett til å foreta en samling av gravene, men heller en plikt til å gjøre dette for å gjøre det enklere for den annen part å finne igjen sine døde etter krigens slutt. ${ }^{10} \mathrm{Hvis}$ disse betraktningene var riktige, hadde Norge en plikt til å samle gravene. Fra norsk side mente man likevel at det ikke var påberopt annet enn at det måtte være hensiktsmessig for begge parter å få samlet gravene på enkelte steder.

Spørsmålet om det var knyttet noen sedvane til arbeidet med å samle krigsgraver, ble undersøkt av Utenriksdepartementet. I tillegg ble det undersøkt hvordan andre land forholdt seg til hensynet til fremmede krigsgraver. I august 1949 rettet norske myndigheter en henvendelse til finske myndigheter med spørsmål om hvordan de hadde forholdt seg til sovjetiske krigsgraver, og om det var mulig å få sovjetiske myndigheter til å gå med på at alle krigsgravene skulle flyttes til Sovjetunionen. ${ }^{11}$ Den norske legasjonen i Helsingfors hadde tidligere mottatt et brev fra chargé d'affaires Helge Leikvang om de sovjetiske krigsgravene i Finland. Han opplyste at ansvaret for krigsgravene var tidligere underlagt Forsvarsministeriet, men at det nå var overført til Innenriksministeriet. Gjennom de ulike länsstyrelsene på steder hvor det fantes graver, var det landsfiskalen (politimester) som var nærmeste myndighet. Landsfiskalen avtalte vedlikeholdet av gravene med privatpersoner, og det ble betalt av Innenriksministeriet. Størsteparten av de sovjetiske soldatene som var begravd på nåværende finsk territorium, var krigsfanger som døde av skadene sine, eller som døde i fangeleirer eller mens de arbeidet på finske gårder, skrev Leikvang. I nærheten av steder der det hadde vært store fangeleirer, ble det som oftest funnet store massegraver som inneholdt 2000-3000 døde. I tillegg fantes det spredte mindre gravsamlinger over hele landet. Dette var som regel krigsfanger som døde i privat arbeid på gårdene. Spørsmålet om å samle flere mindre graver i større enheter var blitt drøftet tidligere. I den anledning hadde det finske Utenriksministeriet kontaktet den sovjetiske legasjonen i Helsingfors med spørsmål om de hadde noe imot en samling av spredte enkeltgraver til større kirkegårder. Argumentet fra finsk side var at dette ville gjøre vedlikeholdet av gravene mer rasjonelt. Legasjonen hadde ikke hatt noe imot dette, og dermed ble gravene som inneholdt færre enn ca. 30 døde, flyttet til større kirkegårder. Alle utgifter i forbindelse med flyttingen ble dekket at finske myndigheter. Det var ikke spørsmål om å flytte de døde soldatene til Sovjetunionen. Leikvang

10 RA, Krigsgravtjenesten, eske 26-35. Notat. «De sovjetiske krigsgraver i Norge». Utenriksdepartementet, Oslo 02.02.1952.

11 RA, Krigsgravtjenesten, eske 26-35. «Russiske krigsgraver i Norge». Utenriksdepartementet. Oslo 23.09.1949. 
opplyste også at hver sovjetisk grav i Finland var markert med et hvitt gresk-katolsk trekors, og på hver kirkegård eller kirkegårdsavdeling var det oppført en rød pyramide av tre med inskripsjon på russisk som viste antallet graver. Til slutt oppga han at ca. 13000 sovjetiske soldater var gravlagt på nåværende finsk territorium. ${ }^{12}$ Tallet her er sannsynligvis for lavt. Nyere forskning i Finland har avdekket at 19085 sovjetiske krigsfanger og 4361 sivile internerte i leirer i Øst-Karelen døde i løpet av årene 1941 til $1944 .^{13}$

I tilknytning til norske myndigheters undersøkelse angående graver i andre land ble det vist til sovjetiske myndigheter i østsonen i Tyskland. De hadde ikke gitt norske myndigheter adgang til å lete etter nordmenn som var antatt å være gravlagt der. Kun i ett tilfelle hadde det på dette tidspunktet vært snakk om å få hjem levninger av norske nazister som døde i Sovjetunionen eller i østsonen i Tyskland.

I Danmark var 28 sovjetiske krigsgraver samlet på en gravplass på Bornholm, anlagt av sovjetiske militære myndigheter. Det var også gravlagt 19000 tyskere i landet, men det var ikke planlagt noen flytting av disse gravene.

$\mathrm{Av}$ andre nasjonaliteters krigsgraver i Norge hadde amerikanerne hentet hjem 35 døde. I tillegg fantes det 320 britiske krigsgraver spredt på 27 steder i landet. Det var ikke planlagt noen samling av disse gravene i 1952. Franske krigsgraver var samlet på krigskirkegården i Narvik. Etter planen skulle Sentralkontoret for krigsgraver utarbeide en oversikt over alle øvrige fremmede krigsgraver i Norge innen 1. juli 1952. ${ }^{14}$ For Norges vedkommende ble også tematikken omkring jugoslaviske og polske krigsgraver et sentralt spørsmål i årene etter flyttingen av de sovjetiske gravene.

Det tyske angrepet på Sovjetunionen den 22. juni 1941, med kodenavn "Operasjon Barbarossa», hadde skapt gruvekkende mye lidelser for sovjetiske soldater, sivile og krigsfanger. Over ti millioner sovjetiske soldater ble drept i kampene mot

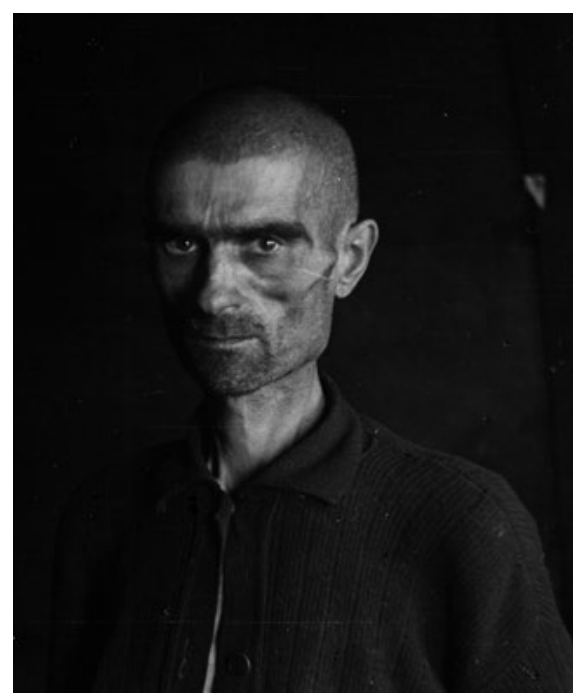

Frigjort sovjetisk krigsfange, Saltfjellet 1945. Arkiv: Riksarkivet.

12 RA, Krigsgravtjenesten, eske 26-35. «Sovjetrussiske krigsgraver i Finland». Kgl. Norsk Legasjon. Helsingfors 15.09.1949.

13 Westerlund, Lars (red.): Prisoners of War and Internees. Oy Nord Print Ab, Helsinki 2008: 8.

14 RA, Krigsgravtjenesten, eske 26-35. Notat. «De sovjetiske krigsgraver i Norge». Utenriksdepartementet, Oslo 02.02.1952. 
tyske styrker. Et tilsvarende antall sivile døde på flukt, av bomber eller av sult og sykdom. Dette var en nådeløs krig, som førte med seg et svært stort antall sovjetiske krigsfanger. Om lag 5,7 millioner sovjetiske soldater ble tatt til fange i tiden etter angrepet og frem til 1945. Av disse døde trolig 3,3 millioner i tysk fangenskap. ${ }^{15}$ Antallet døde er blitt justert litt ned, ifølge nyere forskning. Timothy Snyder oppgir i sin bok Dødsmarkene (2012) at 3,1 millioner sovjetiske krigsfanger ble drept i tyske fangeleirer. ${ }^{16} \mathrm{Om}$ lag 100000 sovjetiske krigsfanger og sivile tvangsarbeidere ble sendt til Norge som slavearbeidskraft for tyskerne for å gjennomføre Hitlers storstilte byggeplaner. Fangenes arbeidskraft ble utnyttet til utbygging av Nordlandsbanen, riksvei 50 (E6), tunnelbygg, etablering av befestninger og flyplasser. Atlanterhavsvollen (Festung Norwegen) ble bygd i form av en mengde bunkere og kanonstillinger langs norskekysten. Formålet var å hindre en eventuell alliert invasjon. Omkring 13700 sovjetiske krigsfanger mistet livet i fangenskap på norsk jord. En del av fangene ble overlevert fra Wehrmacht til SS og henrettet. Kort tid etter krigen startet norske myndigheter arbeidet med rapportering og samling av sovjetiske graver.

15 Streit, C.: Keine Kameraden. Die Wehrmacht und die sowjetischen Kriegsgefangenen 1941-1945. Verlag J.H.W Dietz Nachf., Bonn 1997: 10.

16 Snyder, Timothy: Dødsmarkene: Europa mellom Hitler og Stalin. Gyldendal, Oslo 2012: 202. 


\section{Oppgraving og samling av krigsgraver før «Operasjon asfalt»}

Planleggingen av samlingen av sovjetiske graver i Nord-Norge startet på et tidlig tidspunkt etter frigjøringen. I juni 1945 sendte Distriktskommando Nord-Norge en anmodning til alle lensmenn om innrapportering av funn av graver. Lensmennene ble bedt om å samle inn opplysninger om gravplasser og krigskirkegårder utenom de vanlige kirkegårdene innen lensmannsdistriktene. Opplysninger om beliggenhet, antall begravde, navn og nasjonalitet ble sendt inn. I tillegg til dette ble det oppgitt hvilke ordinære kirkegårder som var blitt brukt som begravelsesplass for personell tilhørende norske og allierte styrker, med angivelse av navn og nasjonalitet på dem som var identifisert. Alle kirkegårder som var blitt brukt til begravelse av tysk personell, ble også registrert. Den norske brigaden ba områdesjefene for Distriktskommando Nord-Norge om å skaffe nødvendig tysk arbeidskraft til å opprette større felles gravsteder, og til arbeidet med å samle inn tidligere begravde sovjetiske krigsfanger til disse. ${ }^{17}$

Kartleggingen av skjebnene til de døde fangene ble en prøvelse for både norske og allierte myndigheter. Gravene med sovjetiske ofre befant seg på krigskirkegårder og ordinære kirkegårder, ved militære anlegg og i utmark, blant annet i myrlendt og vanskelig tilgjengelig fjellterreng. Av politiske grunner hevdet sovjetiske myndigheter at det var ønskelig med flest mulig minnesmerker over det tyske tyranniet, noe de påsto ville legge grunnlaget for kampfelles-

17 RA, DKN, 316 krigsgraver i Nord-Norge. Notat. 1. Norske Brigade. Bodø 07.08.1945. 
skapet mellom det sovjetiske og det norske folk. ${ }^{18}$ De mente at gravene måtte beskyttes og vedlikeholdes, og at flere minnesmerker ville gi større muligheter for sovjetiske representanter til å reise rundt i landet. Sovjetiske myndigheter hadde dermed delte motiver i ønsket om flest mulig graver spredt rundt i hele landet. På den ene siden ønsket de å ta vare på minnet om de døde, og samtidig forsøkte de å få lettere adgang til militære anlegg i nærheten av gravene. Likevel ble det fremmet et forslag om å diskutere med den norske regjeringen hvorvidt de falne sovjetborgerne skulle samles i én gravplass.

Norske militære myndigheter vurderte å la den sovjetiske gravplassen ved infanterileiren ved Setermoen i Bardu bli liggende. Argumentene for dette var at den var godt vedlikeholdt, og at en sovjetisk major hadde uttrykt sin tilfredshet med gravplassen. Det var også en gravplass på Molund, som lå $\mathrm{i}$ nærheten av leiren. Det var ikke ønskelig fra norsk side å ha to krigskirkegårder liggende like ved hverandre. Dersom gravplassen ikke lå i veien for militærøvelsene, var det en mulighet å gjøre gravplassen ved infanterileiren til samlingsplass for distriktets krigsgraver og fjerne gravplassen på Molund. Den militære ledelsen ved Setermoen bestemte seg imidlertid for at gravene ved infanterileiren skulle bli flyttet til krigskirkegården ved Molund. ${ }^{19}$ På dette tidspunktet var det ingen opplysninger som tydet på at man fra norsk side var skeptiske til gravplassens nære beliggenhet til en militærleir og eventuelle besøk av sovjetiske myndigheter.

I 1945 var sovjetiske militære myndigheter opptatt av at de sovjetiske krigsfangenes gravplasser som hovedregel skulle forbli der de var. Etter anvisning fra oberstløytnant Koptjev i Oslo skulle bare gravsteder med opptil ti ofre flyttes. Kaptein Bolstad ved avsnittskommando Narvik mottok følgende instrukser angående gravplassene fra major Petrov:

1) Gravplassene må innrettes og utlegges ordentlig, inngjerdes og minnestötter oppsettes.

2) Man ber om at oppmerksomheten blir henledet på pleie av gravplassene.

3) Såvidt mulig la gjöre gode permanente gjerder og minnestötter.

4) Innen 5.10 .45 innsende til Oslo fotografier i 3 ekspl. av hver enkelt gravplass og kart i liten målestokk hvor gravplassene er påfört. ${ }^{20}$

18 AVPRF, f. 0116, op.27, p. 127, d. 11, 1. 271. Medlem av NKIDs kollegium K.V. Novikovs brev til general-løytnant G.P. Golubev om sovjetiske krigsgraver i Norge, 22.08.1945. Original oversatt av Sven G. Holtsmark, Norge og Sovjetunionen 1917-1955. Institutt for forsvarsstudier og Det russiske vitenskapsakademi, Oslo 1995: 366.

19 RA, DKN, 316 krigsgraver i Nord-Norge. Notat. «Samling av spredte krigsgraver». Molund, Bardu. 18.09.1945.

20 RA, DKN, 316 krigsgraver i Nord-Norge. Oversettelse fra russisk. Brev fra major Petrov til kaptein Bolstad. Tromsø 27.09.1945. 
Major Petrov fortalte Bolstad at dette var instrukser som han hadde fått, og det siste punktet angående fotografier gjaldt bare ham. Fra sovjetisk side forelå det planer om en detaljert kartlegging av gravene på et tidlig tidspunkt etter frigjøringen. Sovjetiske myndigheter var særlig opptatt av vedlikehold av gravene og minnesmerkene, men de var ikke opptatt av å få ofrene identifisert. Over hele landet startet et vanskelig arbeid med oppgraving og samling av sovjetiske ofre.

\subsection{Finnmark}

Den tyske tilbaketrekningen fra Finnmark medførte grusomme lidelser for krigsfangene. Allierte og norske myndigheter forsøkte etter krigen å kartlegge skjebnene til dem som mistet livet under de umenneskelige forholdene fangene ble utsatt for.

De sovjetiske ofrene som ble funnet langs riksveien i Lebesby i Finnmark i 1946, var enten skutt eller slått i hjel. I rapporten fra lensmannen ble det for samtlige ofre oppført at «kjenningsmerke kunne ikke finnes». Hvert av ofrene ble beskrevet etter klær eller uniform, tenner og andre kjenningstegn. Flere av ofrene var blitt gravlagt av norske veiarbeidere eller telegrafarbeidere i 1945. Etter oppgravingen i 1946 ble alle ofrene lagt i kister og gravlagt i en fellesgrav på Lebesby kirkegård. Fredsvennenes hjelpetjeneste, som var en hjelpeorganisasjon stiftet av kvekere, la ned kranser ved gravene. ${ }^{21}$ Rapporten fra lensmannen gir inntrykk av at identifikasjonsarbeidet var vanskelig å gjennomføre et år etter at ofrene ble drept.

I Finnmark var det vanskelig å finne dødsårsak selv om de dødes identitet var oppført på gravkorsene. Organisation Todt ${ }^{22}$ hadde vinteren 1942-43 en leir for sovjetiske krigsfanger ved Skipagurra i Polmak. På samme dag i slutten av mars døde fire krigsfanger i leiren. Nærmere omstendigheter ved disse dødsfallene var ukjent. Likene ble gravlagt om lag tre kilometer ovenfor Skipagurra. Ved graven ble det satt opp et kors med følgende tekst:

Russische Kriegsgefangene Krieg 1941-43 j.

No. 109815. Baljew Fedor - 1904-43 j.

No. 109896. Mesnjnkin Aleksei - 1905 - 43 j.

No. 109629. Saburnenko Ivan $-1900-43 \mathrm{j}$.

No. 109517. Subzow Ivan $-1912-43 \mathrm{j}^{23}$

21 RA, RAFA-2018/D/Da/L0024. «Rapport til Hr. Politimesteren i Vadsø», avgitt av lensmannen i Lebesby. Mehamn 10.10.1946.

22 Organisation Todt OT var en halvmilitær tysk organisasjon oppkalt etter ingeniør Fritz Todt. OT utførte byggearbeid for krigsformål i Wehrmachts tjeneste og benyttet seg for det meste av utenlandsk arbeidskraft.

23 RA, RAFA-2018/D/Da/L0023. «Rapport Polmak lensmannskontor», den 10.01.1946. 
I tillegg til disse fire ofrene ble det også gjennomført oppgraving av seks sovjetiske krigsfanger som var skutt eller drept på annen måte i Skipagurra under den tyske tilbaketrekningen høsten 1944. For tre av russerne forelå det opplysninger om at disse ble skutt av tyske soldater under rømningsforsøk. For de øvrige tre ofrene var det ikke mulig å skaffe noen opplysninger om hvorfor eller hvordan de døde. Et av likene hadde imidlertid tydelige merker av at hodeskallen var knust. Samtlige av de døde fangene hadde ligget gravlagt temmelig grunt i jorden og likene hadde raskt gått i oppløsning. Det var derfor svært vanskelig å finne ut noe om hvordan de hadde blitt behandlet. De døde krigsfangene ble fraktet med båt til Kirkenes sommeren 1945. ${ }^{24}$

Lensmannens rapport i Lebesby i Finnmark fra 1946 vitner om den brutale skjebnen til utmattede sovjetiske krigsfanger som ikke maktet å holde tritt med kolonnene på vei sørover. I midten av oktober 1944 jaget tyskerne store kolonner med sovjetiske krigsfanger forbi Lebesby. Fanger som ikke maktet å holde følge, fikk en dyster skjebne:

En eldre russerfange ble paa grunn av utmattelse etter kollonen. En tysker tok da fangen av veien og med seg til en bakkeskråning. Folk fulgte etter for å se hva det ble gjort med ham. Tyskerne jaget dem bort under trussel med pistolen. Da de var vel i skjul hörte de et smell fra tyskerens pistol. Da kollonen var borte, gikk folkene tilbake og undersøkte. Da fant de fangen skutt i nakken og død. De forteller at fangen graat, da tyskeren med slag og spark tok han av veien og til dødsstedet. Liket var $174 \mathrm{~cm}$, russisk kappe, tresko på föttene, tysk vaapenjakke, seilduksbukse, graae lange strömper, höy panne, graasvart skjegg, haaret borte, kjenningsmerke kunne ikke finnes, bar merke etter en kule i nakken, tennene var gode. ${ }^{25}$

Den døde fangen ble gravlagt av lokalbefolkningen ved Friarfjorden straks etter henrettelsen. I alt ble tolv sovjetiske ofre gravd opp i området langs riksveien på strekningen Ifjord-Storfjordbotn i september 1946. Lensmannen antok at alle ofrene var sovjetiske fanger, som ble tvunget sørover til fots under den tyske tilbaketrekningen fra Finnmark. Etter hvert som fangene ble syke og ikke klarte å holde tritt med transporten, ble de skutt på stedet. Både voksne og barn hadde hørt krigsfanger bli skutt, men kunne ikke bidra med opplysninger om de tyske krigsforbryterne. Ingen vitner kunne gi brukbare signalement på de tyske gjerningsmennene. Det ble sagt at det var «vakten» eller «en tysk offiser». ${ }^{26}$

24 Ibid.

25 RA, RAFA-2018/D/Da/L0024. «Rapport til Hr. Politimesteren i Vadsø», avgitt av lensmannen i Lebesby. Mehamn 10.10.1946.

26 Ibid. 
Først i september 1947 ble gravene i Vardø kommune flyttet. Sognepresten og inspektøren ved Vardø Tvangsarbeidsleir fikk i oppdrag å flytte sovjetiske døde som var gravlagt i utmark til Kiberg kirkegård. I oppgravingsarbeidet deltok også en sjåfør fra Indre Kiberg. Sjåføren hadde oppholdt seg i Russland og tjenestegjort to år i Den røde armé. I oppgravingsarbeidet deltok også tre norske fanger fra tvangsarbeidsleiren, som hadde deltatt i lignende arbeid i Sør-Varanger. Flere av de døde var antakeligvis sovjetiske flygere som var nedskutt av tyskerne. Ifølge opplysninger fra befolkningen i området hadde tyskerne tatt papirer og annet fra likene. Likene var ved oppgravingen i en slik tilstand at det ikke var mulig å lete etter identifikasjonstegn på dem. De døde hadde alle blå uniformer. På bakgrunn av uniformene mente sjåføren at det var en major og en offiser blant de gravlagte. Et av likene var gravlagt i nærheten av Komagvær. Han ble gravlagt av tyskerne tre-fire uker før de trakk seg tilbake fra Finnmark høsten 1944. Et norsk vitne opplyste at dette var liket av en ung mann på trolig 21-22 år, som hadde kommet drivende $\mathrm{i}$ en gummibåt. Han hadde en revolver i hånden og et lite hull midt $\mathrm{i}$ pannen. Det ble antatt at han hadde begått selvmord. Tyskerne hadde fjernet alle papirer fra liket. Vitnet mente at vedkommende var flyger. Da det viste seg å være flere lik i Vardø-distriktet enn man på forhånd antok, ble to lagt i samme kiste. Alle likene som ble funnet, ble gravlagt på den sovjetiske delen av Kiberg kirkegård. ${ }^{27}$ Materialet fra Vardø kan tyde på at det var vanskelig å identifisere de sovjetiske døde som var gravlagt i utmark. Når det gjaldt identifikasjonen av de sovjetiske krigsfangene som døde i Kiberg, var gravkorsene svært viktige for dette arbeidet.

I Nord-Varanger ble det funnet tre uidentifiserte lik av sovjetiske krigsfanger i 1945. I juni samme år ble likene lagt i kister og overlevert til den sovjetiske kommandanten i Kirkenes. Lensmannen i Nesseby fortalte at det hadde vært sovjetiske krigsfanger i dette distriktet under hele krigen, og han antok at mange fanger var omkommet i området. Han trodde derfor at de døde fangene var gravlagt rundt omkring uten at det var mulig å stedfeste alle gravene. En kartlegging av antall graver, navn på ofrene, fødselsdato og fødested mente lensmannen det var umulig å si noe om. Han håpet at en eventuell åpning av gravene som var funnet, ville gi noen svar på disse spørsmålene. Lensmannen i Gamvik og Lebesby fortalte at telegrafarbeidere hadde funnet seks døde sovjetiske krigsfanger sommeren 1945. Alle ofrene var skutt i nakken, og alt tydet på at de var mishandlet før henrettelsen. Ingen av ofrene hadde identifikasjonsmerke eller annen informasjon på seg som kunne gi noen opplysninger om navn eller adresse. Med de vanskelige for-

27 RA, RAFA-2018/D/Da/L0024. «Rapport om flytning av sovjetrussiske falne til Kiberg Kirkegård, Vardø prestegjeld». Vardø 12.09.1947. 


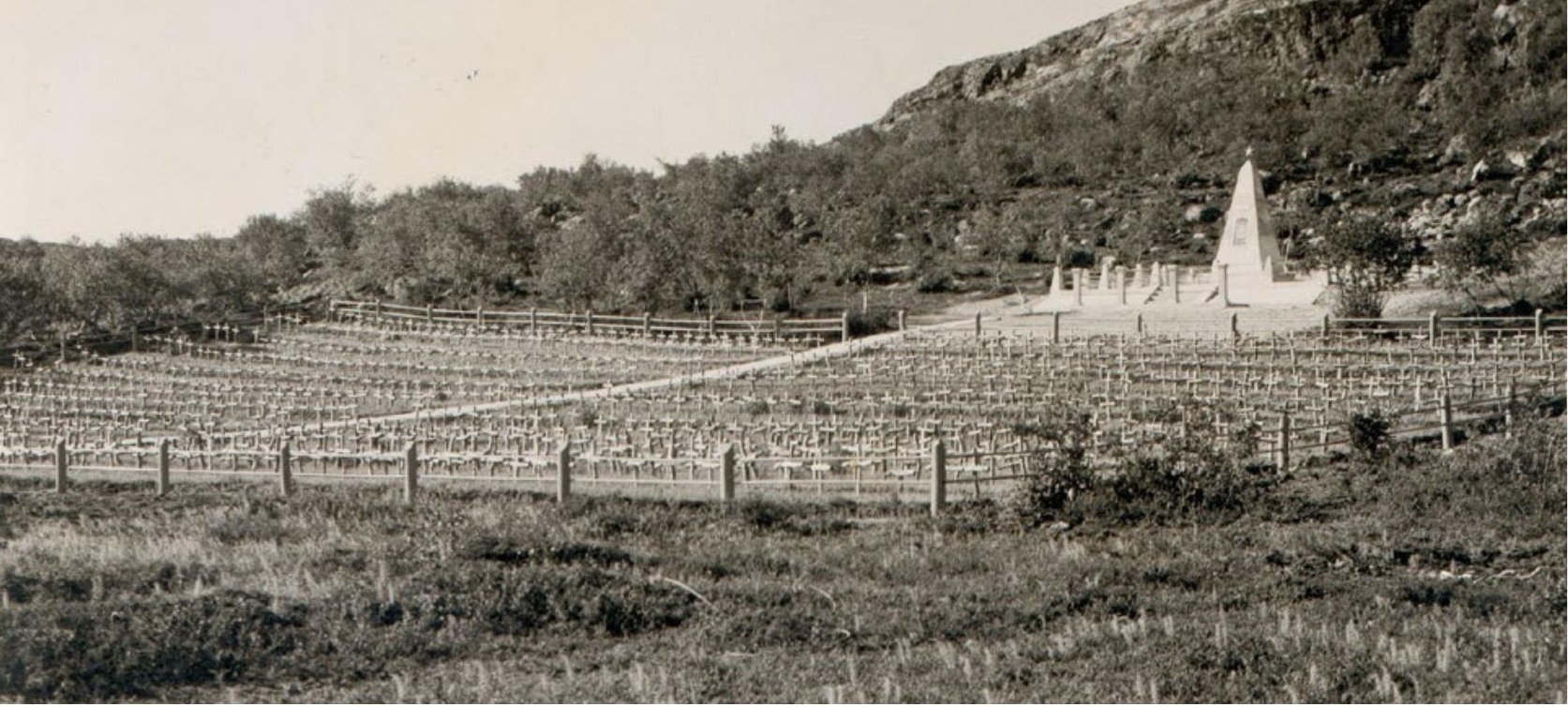

Kirkegården på Noselva, Høybuktmoen 1945. Arkiv: Morten Kasbergsen.

holdene, både før og etter den tyske kapitulasjonen, hadde man ingen annen mulighet enn å begrave likene på stedet der de ble funnet. ${ }^{28}$ Det hendte også at krigsfanger ble kastet på sjøen etter at de var drept. Lensmannen i Kistrand i Finnmark opplyste i en rapport i 1946 at sivile hadde vært vitne til at lik av sovjetiske krigsfanger ble bundet fast til steiner og kastet på sjøen i Indre Billefjord. Det var ukjent hvor mange som hadde lidd samme skjebne. ${ }^{29}$

Sør-Varanger fikk føle krigens tragedier på nært hold som ingen andre lokalmiljøer i Norge. Et betydelig antall tyske og østerrikske soldater preget lokalmiljøet i stor grad. Det samme gjorde tusener av krigsfanger, desertører, tvangsarbeidere og frivillig arbeidskraft fra inn- og utland. Sovjetiske soldater og overlevende fanger reiste et minnesmerke i 1944-45 på Noselva ved Høybuktmoen og et ved Skafferhullet i Elvenes til minne om de flere tusen sovjetiske krigsfangene som måtte bøte med livet i Sør-Varanger. Ifølge opplysninger fra Sør-Varanger historielag var 1431 døde sovjetiske krigsfanger gravlagt på krigskirkegården på Høybuktmoen. Om lag 2300 sovjetiske krigsfangegraver er registrert i kommunen. ${ }^{30}$ Et bilde av kirkegården på Noselva fra 1945 viser at stedet var dekket med mange hundre kors som markerte individuelle graver. Alle korsene ble fjernet i forbindelse med flyttingen av gravene under «Operasjon asfalt».

28 RA, RAFA-2018/Da 23 saksarkiv. Politimesteren i Vadsø. "Oppgave over sovjetrussiske borgere som under okkupasjonen er omkommet i Norge». Vadsø 01.02.1946.

29 RA, RAFA-2018/D/Da/L0023. «Oppgave over sovjetrussiske borgere som under okkupasjonen er omkommet i Norge». Kistrand lensmannskontor, Kolvik 13.05.1946.

30 Sør-Varanger historielag: Sør-Varanger under 2. verdenskrig, arena i stormaktskonflikt. Historielaget, Kirkenes 1997: 148 og 151. 
Kirkegården på Høybuktmoen var den største i Norge for sovjetiske krigsfanger, med 1431 registrerte graver. Minnesmerket, som ble laget i 1945 av medfangene til de døde, ble revet noen år etter krigen på grunn av store teleskader som medførte at betongklossene gikk i stykker. I stedet ble det plassert en standard minnestein fra Krigsgravtjenesten med inskripsjon i samme område. I forbindelse med «Operasjon asfalt» ble de fleste av de gravlagte overført til Tjøtta i Nordland. ${ }^{31}$

Et stort sykehus ble bygd i fangeleiren Stalag 322 på Elvenes for å behandle både tyske sårede fra Murmanskfronten og sovjetiske krigsfanger med dårlig helsetilstand på grunn av sykdom. Sykdommene til fangene var som regel forårsaket av generell fysisk svekkelse, og hjerte- eller sirkulasjonsproblemer og tuberkulose var blant de vanligste årsakene til dødsfallene blant fangene i leiren på Elvenes. Fangene som døde på Elvenes, ble registrert med dødsårsak og gravsted på fangekortet. Dette ble som regel registrert enten bak på fangekortet (Personalkarte I) eller nederst på forsiden.

Fangekortene fra Elvenes identifiserer egentlig ikke et eget gravsted for krigsfangene, men noen sykehus- og gravdokumenter gir en oversikt over

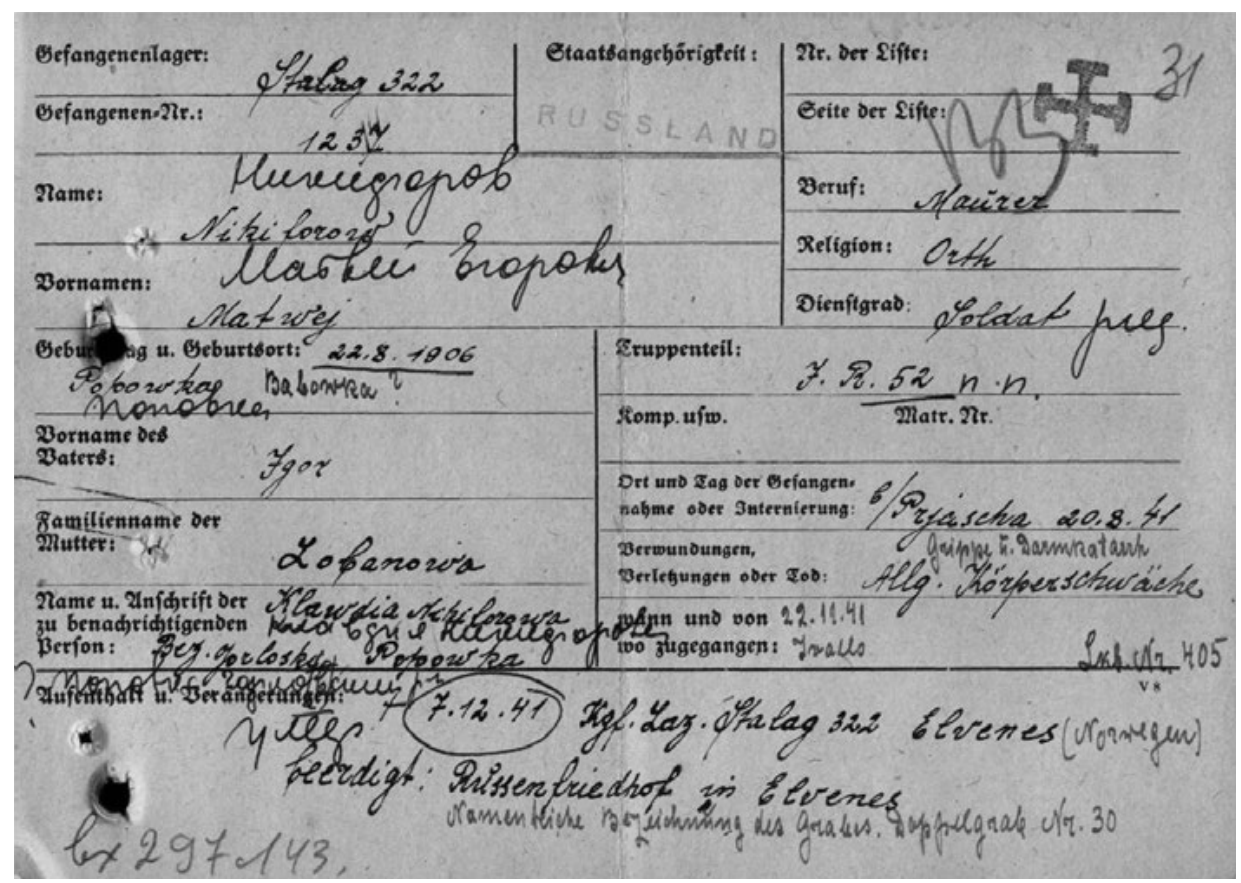

Sykehusdokument fra Elvenes som viser registrering av dødsfall. Foto: www.obd-memorial.ru.

31 Notisen er antakelig fra Sør-Varanger Arbeiderblad. Ikke angitt dato og årstall. Konservator Steinar Wikan ved Sør-Varanger Museum gir en beskrivelse av krigsminnesmerker i Sør-Varanger. Wikan oppgir her at om lag 4000 sovjetiske krigsfanger skal være gravlagt i kommunen. 
strukturen på kirkegården. I mange tilfeller registrerte den tyske administrasjonen at gravene var merket med navn, eller at de var merket med både navn og gravnummer. Det faktum at gravene var registrert med gravnummer, kan tyde på at det har eksistert en detaljert plan over kirkegården. I dag finnes dokumentasjon på at over 600 sovjetiske krigsfanger mistet livet på Elvenes. Et av de siste ofrene som ble registrert gravlagt på Elvenes, var Tichon Ewstegenej Schujkin. Han ble gravlagt den 20. september 1944.

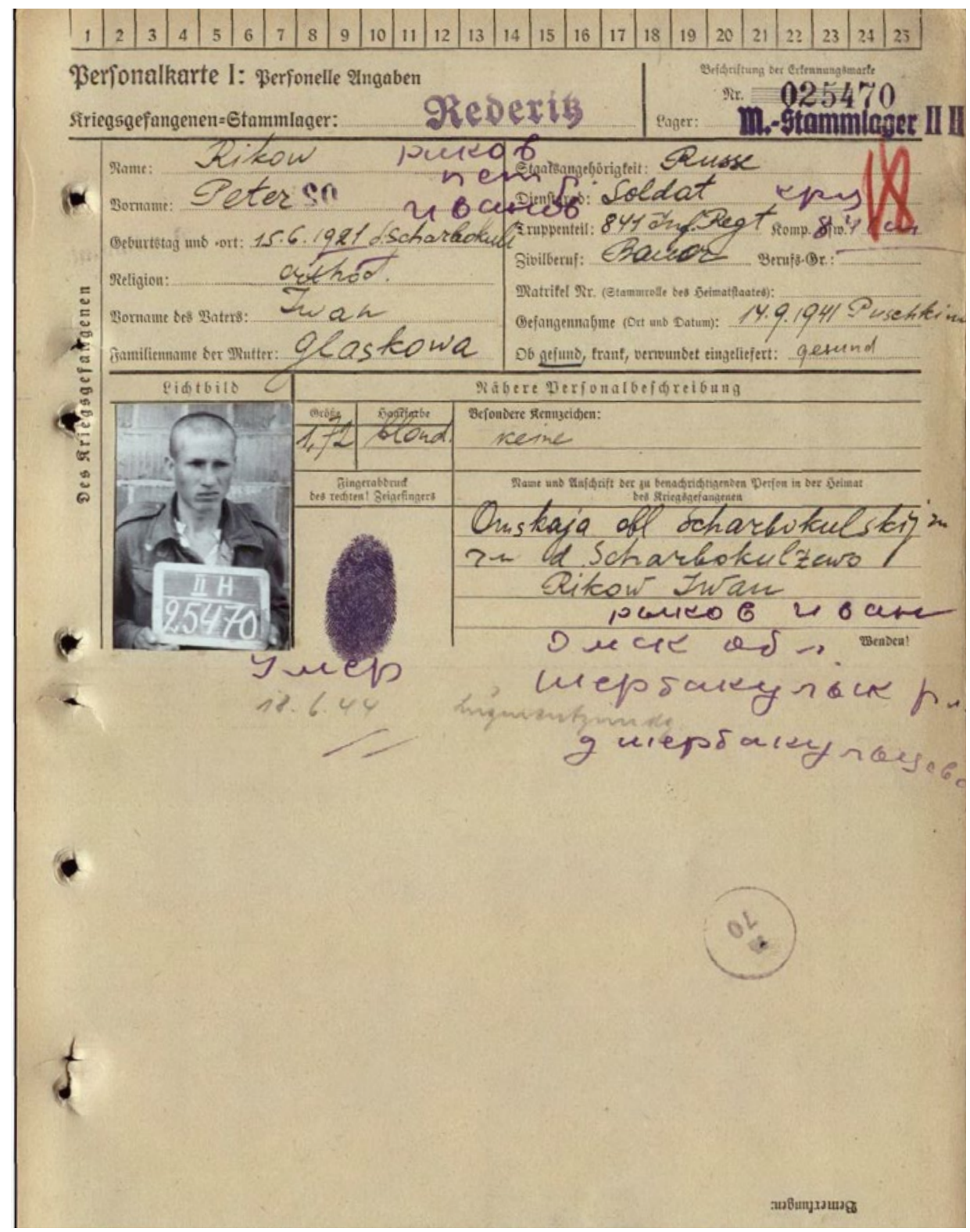

Fangekort som viser registrering av personinformasjon, Elvenes. Foto: www.obd-memorial.ru. 


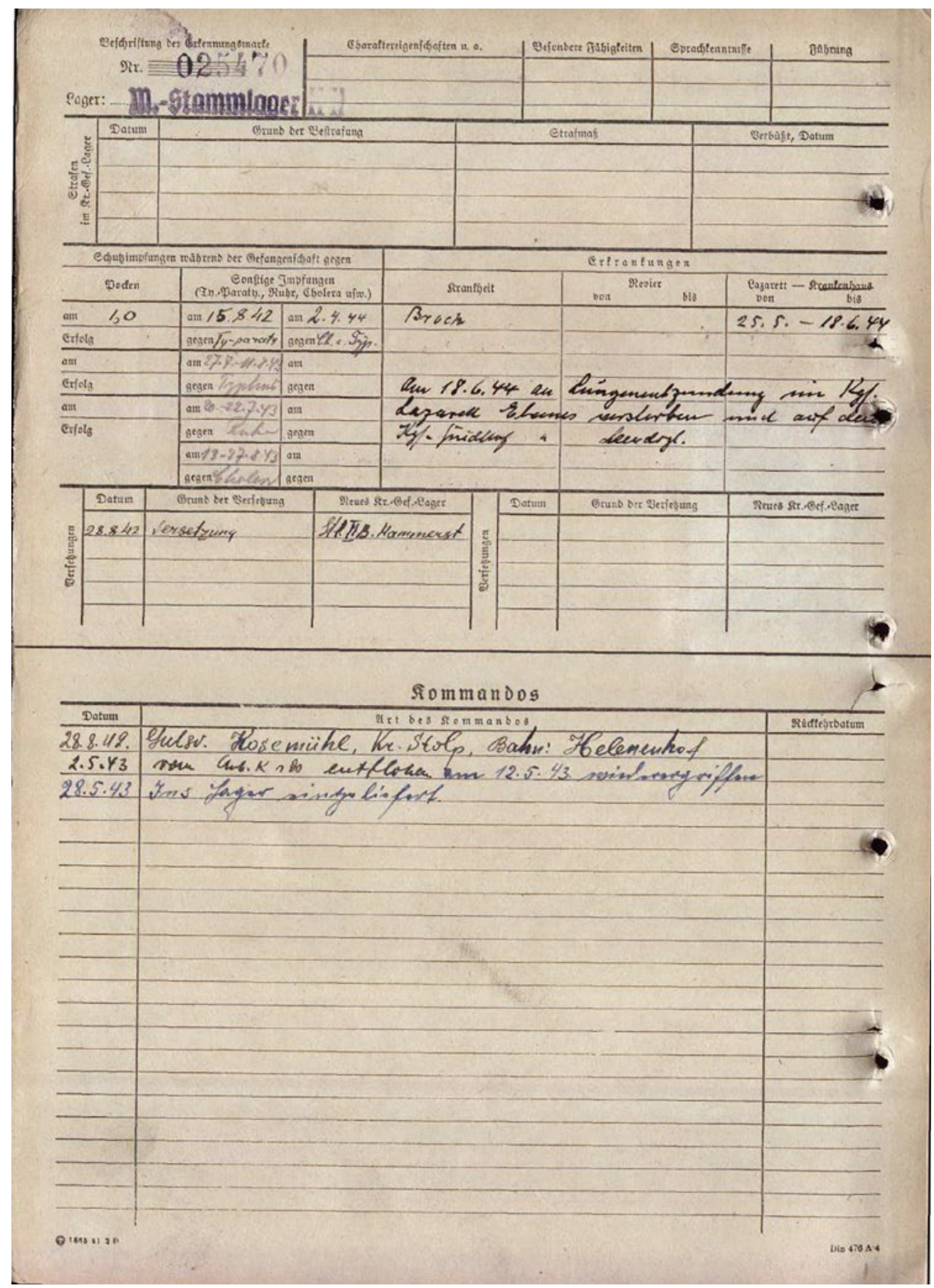

Fangekort som viser registrering av dødsårsak og gravsted, Elvenes. Foto: www.obd-memorial.ru. 


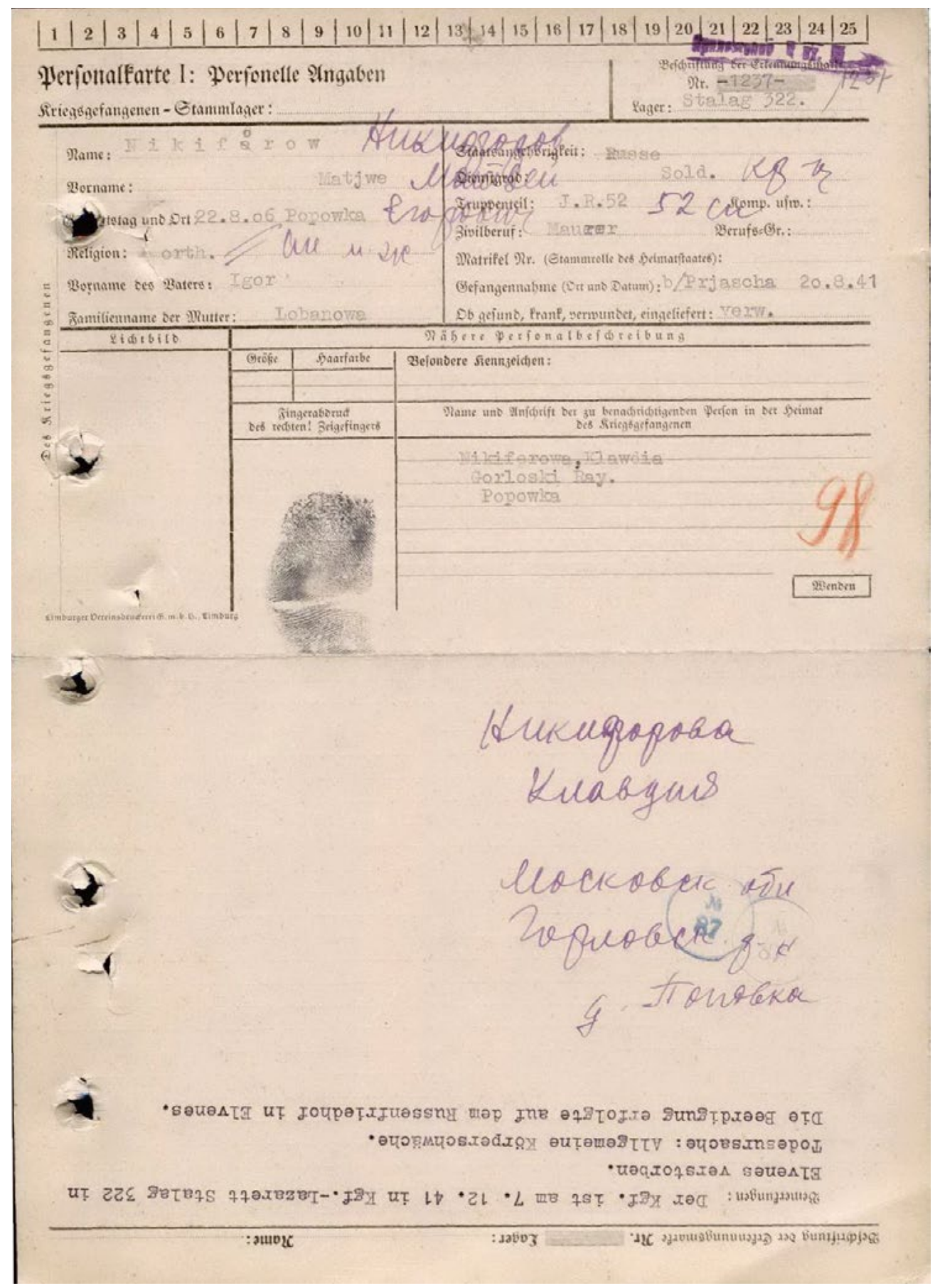

Fangekort fra Elvenes som viser registrering av dødsfall. Foto: www.obd-memorial.ru. 
Vladimir Nikolayevich Kalnin overlevde den tyske fangeleiren i Vladimir-Volynsk i Ukraina og ble senere sendt til Kirkenes. Han beskriver fangenes triste skjebne i Ukraina, men også hjelpsomme nordmenn:

Vi ble sendt til fengselet i Lutsk. Bygningen var forferdelig: en forferdelig stank, fuktig og ikke et eneste tørt sted å stå på. Det var plankesenger med to eller tre nivåer. Syke mennesker lå over alt. De var døende. I dette fengselet møtte jeg oberstløytnanten fra troppen min. Siden da holdt vi sammen. Det var kaldt ute, septemberoktober, og jeg hadde bare skjorte og ingen lue. Sommer skjorte og sommer bukser. Oberstløytnanten insisterte på at jeg måtte finne noen klær, ellers ville jeg dø av kulde og ikke av sult. Vi begynte å se hvor vi kunne ta klær. På en planke seng så vi en ung sjømann, som var døende. Så snart han var død, gikk vi til ham for å ta frakken hans. Vi klarte å ta av ham frakken, men jeg klarte ikke å ta den på meg, det var en død manns frakk. Nå kunne jeg til og med sitte ved en død mann og spise et måltid, det brydde meg ikke. Jeg tok med meg frakken og bar på den i flere dager. Til slutt ble det for kaldt og jeg tok på meg frakken. Senere ble vi sendt til en konsentrasjonsleir i Khelm. Det var flere leire der. I hver camp var det 60000 personer. Folk døde som fluer, 30-40 hver dag. Døde kropper ble tatt i en lastebil hver dag. Selv om kirkegården var like utenfor gjerdet, var det alltid flere lik å fjerne. Kirkegården var faktisk en grøft. De døde kroppene ble kastet i grøften og dekket med et tynt lag av jord. De begravde likene så ut som skjeletter, svært tynne. I Khelm kjente vi ikke hverandre, og vi så ikke hverandre. ${ }^{32}$

Dette endret seg da han ble sendt til Norge:

I Norge hjalp vi hverandre, vi delte alt ... brød ... sigarettter. Vi kom til Kirkenes og nordmenn hjalp oss mye. Takket være nordmennene døde ikke så mange krigsfanger, bare en eller to på flere dager. Vi spiste alt vi fikk tak i. Folk døde for det meste av sult, ikke av infeksjon. ${ }^{33}$

Kameratskapet mellom fangene og hjelpende nordmenn holdt motet oppe, forteller Vladimir Nikolayevich Kalnin.

Nils Henry Johansen fra Kirkenes ble vitne til krigshandlingene i Kirkenes og Bjørnevatn i oktober 1944. Han forteller at de sovjetiske soldatene kom frem til Høybuktmoen og Noselva, hvor de befridde de resterende av flere hundre sivile sovjetiske tvangsarbeidere (kvinner, barn og eldre) som tyskerne hadde fraktet til Kirkenes fra Leningrad-området i krigsårene. De sivile tvangs-

32 Falstadsenterets arkiv, intervju med Vladimir Nikolayevich Kalnin. 2010.

33 Ibid. 
arbeiderne hadde bodd i gammer ved Høybuktmoen. ${ }^{34}$ Det var kun en mindre tropp som ankom selve Kirkenes, og hovedoffensiven fortsatte vestover.

Den 23. oktober 1944 begynte den 14. armé offensiven mot Kirkenes. Skjønt en offensiv i egentlig forstand var det nok ikke. Troppeforflyttingene langs veien mot Kirkenes minnet mer om veireparasjoner enn militær fremrykking. Veien var dårlig, minelagt og blokkert, så den var vanskelig å gå på selv for en infanterist. I løpet av dagen forflyttet armékorpset seg bare to kilometer. Derfor ga sjefen for den 45. skytterdivisjon ordre om å krysse Jarfjorden nord for bygda Tårnet, angripe fienden bakfra og blokkere retrettveien i retning Kirkenes. Men på grunn av manglende proviant og ammunisjon klarte den ikke å komme frem til det fastsatte tidspunktet. Det 99. armékorps fortsatte fremrykkingen mot Kirkenes sørfra den 24. oktober. Om kvelden kom to avdelinger som tilhørte den 10. gardedivisjonen og den 65 . skytterdivisjon frem til Bjørnevatn jernbanestasjon, ti kilometer fra Kirkenes. Soldatene tilhørende skytterdivisjonen fant 3500 sivile i en av gruvegangene, i lagringsplasser og tilfluktsrom i fjellet, ifølge de militære protokollene fra operasjonen. ${ }^{35}$ Etter dette var tyskerne drevet ut av Jarfjordbotn, Elvenes og Skoltefossen ved Boris Gleb. Midt på dagen den 25. oktober var hele Kirkenes inntatt av de sovjetiske troppene. Om kvelden samme dag ble det offentliggjort en ordre fra Stalin. Ordren var å gi en belønning til de enhetene som hadde markert seg positivt. Avdelingene som hadde markert seg, fikk i tillegg til belønning også æresnavnet «Kirkenesskaja». Moskva salutterte også på Den røde plass til ære for Den karelske fronten og for Nordflåten. ${ }^{36}$

Til tross for en betydelig overlegenhet i styrker klarte ikke den sovjetiske militærledelsen å utnytte dette fullt ut og oppnå hovedmålet om å fange tyskerne i et arktisk Stalingrad. Den sovjetiske offensiven begrenset seg således i det vesentlige til å jage tyskerne vestover. En siste mulighet var å stenge av Varangerfjorden og tilintetgjøre den tyske armeen da de evakuerte via sjøveien, men denne sjansen ble også forspilt.

Før offensivens begynnelse samlet man sammen nesten 180000 mann av troppene fra den karelske frontens 14. armé og Nordflåten i retning av Murmansk. ${ }^{37}$ De fem sovjetiske infanterikorpsene bestod før Petsamo-Kirkenes-operasjonen av 96800 personer. I forbindelse med operasjonen ble de forsterket med syv artilleriregimenter, 17 divisjonsenheter, fem pansertankregimenter, 29 ingeniørbataljoner og to amfibiske bataljoner. Enhetene til Nordflåten som angrep fra Srednij-halvøyas side (på Fiskerhalvøya), bestod

34 Gorter, Anastasia A., Waling T. Gorter og Michael N. Suprun: Frigjøringen av Øst-Finnmark 1944-45. Arkhangelsk Pomor, Arkhangelsk 2005: 235.

35 Ibid.: 55-63.

36 Ibid.: 69.

37 Ibid.: 29. 
av 14500 soldater og offiserer. De ble støttet av fire artilleriregimenter og besetninger fra flåtens skip der. I løpet av operasjonen ble den 14. armé ytterligere forsterket med ferske styrker, inkludert det 133. skytterkorps og spesialstyrker. Nordflåtens flyvåpen deltok i operasjonen med 275 av sine 563 fly. I tillegg deltok 65 fly fra Luftforsvarets 122 . jegerdivisjon i operasjonen. ${ }^{38}$ Fra norsk side er det anslått at Den røde armé hadde ca. 5000 soldater stasjonert ved 35 sovjetiske militærleirer i Sør-Varanger i tiden 1944-1945. Nesten alle leirene var plassert øst for Neidenelva. Russerne ble værende i kommunen i nærmere et år. De krysset grensen til Norge den 18. oktober i tilknytning til frigjøringskampene, og først den 25. september 1945 forlot de siste sovjetiske soldatene norsk territorium. ${ }^{39}$ For å dekorere alle som deltok i kampene i Petsamo-Kirkenes-området, innstiftet den sovjetiske regjeringen medaljen «For forsvaret av sovjetisk nordområde». Sovjetiske øverstkommanderende har tre ganger i sine befalinger understreket ingeniørstyrkenes innsats og den utmerkede måten de oppfylte sin krevende plikt på. ${ }^{40}$ Den sovjetiske tilbaketrekningen i slutten av september 1945 skjedde i samsvar med norsk-sovjetisk avtale. ${ }^{41}$

Sovjetiske myndigheter har ofte fremstilt det som om frigjøringen av Øst-Finnmark gjaldt hele Finnmark, for ikke å si hele Nord-Norge, mens norske historikere har vært nøye med å understreke at det bare dreide seg om Øst-Finnmark. I omtalen av frigjøringen blir utfordringene ved det norsk-russiske samarbeidet fremhevet i flere historieverk. Knut Einar Eriksen og Terje Halvorsen har vektlagt at den sovjetiske frigjøringen av Sør-Varanger bekreftet at Norge lå i skjæringspunktet mellom øst og vest og ikke entydig kunne regnes til Vestmaktene. Regjeringen måtte være på vakt, men samtidig sørge for et godt forhold til Sovjetunionen. Norske myndigheter kunne gjøre lite med konfliktene ved samarbeidet. Dette gjaldt avissensur, treg saksbehandling på sovjetisk side og forventninger om større norsk militær innsats. ${ }^{42}$ Olav Riste påpekte at norske myndigheter stod foran en vanskelig oppgave med å bygge opp et effektivt militært og sivilt apparat så å si fra bunnen av og med svært beskjedne midler. Hjelpen vestfra var avhengig av de vestallierte og deres frykt for å trå russerne for nær. ${ }^{43}$ En del av problemene utefron-

38 Ibid.: 89 .

39 Sør-Varanger historielag: Sør-Varanger under 2. verdenskrig. Arena i stormaktskonflikt. Kirkenes 1997: 173. Oversikt utarbeidet av Johan B. Siira.

40 Wara, Kalle: Det tiende slaget. Falken Forlag A/S, Oslo 2004: 71.

41 Holtsmark, Sven G: Norge og Sovjetunionen 1917-1955. Institutt for forsvarsstudier og Det russiske vitenskapsakademi, Oslo 1995: 367.

42 Eriksen, Knut Einar og Halvorsen, Terje: Norge i krig. Frigjøring. Bd. 8. Aschehoug \& Co, Oslo 1987: 82-83.

43 Riste, Olav: «London-regjeringa» Norge i krigsalliansen 1940-1945. Bd. II. Det Norske Samlaget, Oslo 1979: 202. 
ten fikk i Finnmark, må tilskrives at Sovjetunionen ikke informerte om sine krigsplaner på Nordkalotten. Først da sovjetiske styrker stod ved den norske grensen, erklærte utenriksminister Vjatsjeslav Molotov at norske styrker var velkomne, og han lovte dem hjelp og støtte. ${ }^{44}$ Løftet ble innfridd, og russerne holdt seg til frigjøringsavtalene og blandet seg lite inn i norsk sivilt styre.

Innenfor sovjetisk historieforskning er det påpekt at sovjetiske styrkers frigjøring av Øst-Finnmark var starten på frigjøringen av Norge og avverget tvangsevakueringen av de fleste sivile innbyggere og brenning av bygdene $\mathrm{i}$ Varanger-området. ${ }^{45}$ Norske historikere hevder at for den vanlige sovjetiske soldat og de norske privatpersonene $\mathrm{i}$ området fortonte frigjøringen av Øst-Finnmark seg uten tvil som heltemodig, og som en stor suksess. De sovjetiske soldatene betraktet seg selv naturligvis som befriere. ${ }^{46}$

I sluttfasen av krigen var det ikke bare sovjetiske krigsfanger som mistet livet på norsk jord, men også sovjetiske soldater som deltok i frigjøringen av Øst-Finnmark. Etter krigens slutt var sovjetiske myndigheter opptatt av å få gravlagt de falne soldatene i hjemlandet, men dette gjaldt ikke krigsfangene som ble funnet i samme område. De sovjetiske tapene under PetsamoKirkenes-operasjonen var store. I et norsk-russisk bokprosjekt om frigjøringen av Øst-Finnmark er det oppgitt at 21233 ble registrert som drepte, sårede og savnede under operasjonen, derav 2122 på norsk jord. Sovjetunionen hadde registrert 6084 drepte og 15149 sårede under Petsamo-Kirkenes-operasjonen. I kampene i Norge fra 18. oktober 1944 mistet, i henhold til generalstabens data, som ble lagt frem for den norske regjeringen i januar 1945, 611 soldater og offiserer livet, mens 1501 personer ble såret. ${ }^{47}$ De sovjetiske soldatene som falt under Petsamo-Kirkenes-operasjonen, tok Den røde armé med seg tilbake til hjemlandet og gravla der. Dette gjaldt også de som falt ved Staanga (Stonga mellom Kirkenes og Neiden) under kampene ved Neiden. Sovjetiske falne ble gravlagt ved Akhmalahti på sovjetisk side av Pasvikelva, et sted hvor store sovjetiske styrker hadde passert grensen til Norge etter harde kamper den 22. og 23. oktober 1944. Noen ble gravlagt ved Nikel. ${ }^{48}$

I forbindelse med overføringen av de sovjetiske soldatene som falt i kampene høsten 1944, ba sovjetiske myndigheter om assistanse fra norsk side. Den sovjetiske ambassaden overleverte et notat til Utenriksdepartementet i saken:

44 Eriksen, Knut Einar og Halvorsen, Terje: Norge i krig. Frigjøring. Bd. 8. Aschehoug \& Co, Oslo 1987: 82.

45 Gorter, Anastasia A., Waling T. Gorter og Michael N. Suprun: Frigiøringen av Øst-Finnmark 1944-45. Arkhangelsk Pomor, Arkhangelsk 2005: 85.

46 Riste, Olav: «London-regjeringa» Norge i krigsalliansen 1940-1945. Bd. II. Det Norske Samlaget, Oslo 1979: 190.

47 Gorter, Anastasia A., Waling T. Gorter og Michael N. Suprun: Frigiøringen av Øst-Finnmark 1944-45. Arkhangelsk Pomor, Arkhangelsk 2005: 97.

48 Ibid.: 17. 
Paa norsk omraade ved Fossgaard og Svanvik er det blitt funnet et stort antall lik av röde armé-soldater som er falt under militäroperasjonene og som ble begravet vinterstid paa liten dybde. Sovjet-regjeringen ber den norske regjering om aa ta de skritt den kan for aa faa de gjenfundne lik lagt $i$ kister og transportert til grensen, hvor sovjet-militäre myndigheter vil ta imot disse lik med militäre äresbevisninger for aa begrave dem paa SSSR's omraade. ${ }^{49}$

I 1946 og 1947 ble det funnet 44 ukjente soldatgraver på ulike steder i Sør-Varanger. Flesteparten av gravene ble funnet i Jarford og i Neiden. Politimesteren i Sør-Varanger, Jonas Madsø, opplyste at dette antakelig var soldater som hadde falt under krigen høsten 1944. Madsø arbeidet for å få flyttet de døde til de sovjetiske gravplassene på Elvenes eller Høybuktmoen. Han var klar over at det ville bli vanskelig å skaffe arbeidsmannskap til oppgravingen og at lønnen måtte være høy, om man i det hele tatt fikk tak i noen. Med tanke på vanskelighetene med å få tak i folk, foreslo Madsø for fylkesmannen i Finnmark at Forsvarsdepartementet skulle beordre garnisonen i Sør-Varanger til å gjennomføre oppgravingen mot refusjon av utgiftene. ${ }^{50}$

Det ble en utfordrende oppgaveå kartlegge og identifisere sovjetiske soldater som falt i kamp mot tyske styrker på norsk jord. På sovjetisk side ble det nedsatt en egen kommisjon som i 1946 hadde ansvaret for hjemsendelsen av soldater som falt i kamp under det som ble beskrevet som erobringen av Sør-Varanger. Gravstedet til en sovjetisk fange, en fellesgrav ved Holmfors og liket av en sovjetisk soldat som døde av vådeskudd, ønsket kommisjonen ikke å befatte seg med. Da de siste seks likene ble avlevert ved Storskog, var kommisjonen møtt frem. Et musikkorps spilte en sørgemarsj og sivile sovjetiske kvinner la en stor krans på hver kiste. Deretter ble både den norske og sovjetiske nasjonalsangen spilt, og til slutt kjørte bilene over grensen til Sovjetunionen mens sørgemarsjen ble spilt på nytt. Den sovjetiske kommisjonen tok deretter avskjed og takket de norske soldatene for deres hjelpsomhet og samvittighetsfulle arbeid. En spesiell takk ble rettet til kompaniets befal for den store forståelsen som var vist kommisjonen og russerne i en for dem så viktig sak..$^{51}$

Oberstløytnant Prokhorow ved den sovjetiske ambassaden i Oslo besøkte Sør-Varanger i august 1948. Her møtte han ordfører, politimester og sogneprest angående de sovjetiske krigsgravene i området. Sognepresten var engasjert i saken om de sovjetiske gravene og mente det var beklagelig at Sen-

49 RA, Krigsgravtjenesten, eske 26-35. «Russiske soldaters lik funnet ved Fossgaard og Svanvik». Oslo 19.06.1946.

50 RA, Krigsgravtjenesten, eske 26-35. «Sovjetiske krigsgraver i Sør-Varanger». Kirkenes 27.08.1948.

51 RA, Krigsgravtjenesten, eske 26-35. Rapport. «Ad russiske lik-kommisjons arbeid ved hjemsendelse av russiske falne soldater i Sør-Varanger». Kirkenes 30.07.1946. 
tralkontoret for krigsgraver ikke hadde besvart hans henvendelse angående gravene. Sognepresten fortalte at samtlige var uforsvarlig gravlagt. Likene lå ikke dypt nok, og de var utsatt for vær, vind og rovdyr.

Etter en anmodning fra Distriktskommando Nord-Norge i juni 1947 hadde politiet ordnet med gravleggingen av lik i Sør-Varanger. Det ble da utført en del arbeid, men ettersom man stadig fant nye lik, ble jobben så kostbar og komplisert at den ble innstilt inntil videre. Sognepresten sendte melding til distriktskontoret for krigsgraver på Bardu om forholdene ved Tårnet og ba om at det ble laget en kirkegård der hvor likene befant seg, slik at de slapp å flytte dem. Han påpekte også at politiet ikke hadde nok folk til å ta seg av arbeidet som gjenstod med gravene. Sognepresten foreslo også at garnisonen Sør-Varanger burde utføre arbeidet og sette gravstedene ved Elvenes og Høybuktmoen i stand. Ingenting ble gjort, og sognepresten følte at de ble satt i gapestokk når de sovjetiske utsendingene kom for å inspisere gravene. Det var knyttet usikkerhet til de økonomisk spørsmålene vedrørende flyttingen, og en kunne ikke forvente at kommunale myndigheter tok initiativ til flytting og vedlikehold av gravene uten at de hadde de nødvendige direktiver og økonomiske garantier. Ordføreren i Sør-Varanger hadde sagt til Prokhorow at kommunen ikke maktet å bære den økonomiske byrden knyttet til arbeidet med gravene, men at de selvsagt ville være behjelpelig på alle måter når de nødvendige vedtak vedrørende økonomi var fattet, og når man fikk de nødvendige direktivene. Prokhorow ville legge frem saken for Utenriksdepartementet, general Dahl og fylkesmannen for å prøve å få ordnet de $ø$ konomiske forholdene. For å få fortgang i saken skrev sognepresten et brev til biskopen i Hålogaland der han tilbød sin hjelp med å kontakte de rette myndighetene og Sentralkontoret for krigsgraver, slik at man kunne komme frem til en verdig ordning med gravene. ${ }^{52}$

Prokhorow hadde også et møte med fylkesmannen i Finnmark angående krigsgravene. I møtet informerte han fylkesmannen om at det var om lag 900 lik i Alta-distriktet som var mer eller mindre mangelfullt begravd. Han mente at det var lignende forhold også andre steder i Finnmark, og hevdet at en måtte regne med at det på øde strekninger i fylket lå et betydelig antall sovjetiske falne som ingen visste om. Fylkesmannen viste til at det allerede ved frigjøringen ble satt i gang undersøkelser om de sovjetiske ofrene i fylket. Politimestre, lensmenn og sogneprester hadde sørget for samling og gravlegging av et stort antall døde sovjetiske statsborgere. En total gjennomsøkning av hele fylket med sikte på å finne lik som lå på ukjente steder, var en ugjennomførbar oppgave, tatt i betraktning at det her dreide seg om et landområde på nærmere $50000 \mathrm{~km}^{2}$. Siden befolkningen innrapporterte alle tilfeller av funn av døde,

S2 RA, Krigsgravtjenesten, eske 26-35. «De sovjetiske krigsgraver i Sør-Varanger».26.07.1948. 
mente fylkesmannen at tjenestemennene i de ulike distriktene hadde full oversikt over alt arbeidet som var gjort og hva som eventuelt måtte gjenstå. ${ }^{33}$

I 1949 ble sovjetiske krigsgraver i Sør-Varanger flyttet fra Jarfjord til den sovjetiske krigskirkegården ved Høybuktmoen. ${ }^{54}$ Det ble sagt fra sovjetisk side at det dreide seg om 300 russergraver, men det var bare funnet 76. Kaptein Arntzen fra Sentralkontoret for krigsgraver avviste at antallet graver var så høyt. Kapteinen fortalte at det totalt var 93 forskjellige gravplasser for russere i Nord-Norge, og at Sentralkontoret forsøkte å få samlet disse så langt det var økonomisk forsvarlig. ${ }^{55}$

I 1950 ga kaptein Arntzen en oversikt over antall gravlagte ved Høybuktmoen krigskirkegård. Etter at alle ofre som ble funnet i årene 1946 til 1949, var gravlagt, var antallet totalt 1509 sovjetiske ofre på Høybuktmoen, ifølge Arntzen. Angående vedlikeholdet skriver Arntzen at gjerdet var delvis ødelagt, og at de fleste av dem som var gravlagt av norske myndigheter, lå utenfor gjerdet. De fleste av gravene på Høybuktmoen hadde kors av bjørkegreiner som ikke var barket, og hadde råtnet. Kapteinen mente at de så veldig stygge ut. I tillegg var jorden overgrodd av ugress. ${ }^{56}$ Alle korsene ble fjernet da gravene ble flyttet til Tjøtta et år senere.

I oktober 1951 informerte skoleinspektør Dølvik Krigsgravtjenesten om overføringen av sovjetiske falne fra Norge til Sovjetunionen. Han bekreftet at russerne selv tok rede på sine falne under kampene i Finnmark høsten 1944. De ble først gravlagt midlertidig i Sør-Varanger og deretter gravd opp igjen og ført tilbake til sovjetisk område. Dølvik var usikker på hvorvidt dette gjaldt alle. Det var tilfeller der de falne i første omgang var dårlig gravlagt, og disse ble senere tatt opp og gravlagt dypere i jorden, men Dølvik visste ikke om alle disse ble gravd opp nok en gang og ført tilbake til Sovjetunionen. ${ }^{57}$

For sovjetiske myndigheter var det viktig å få hjemsendt de sovjetiske falne soldatene så raskt som mulig. Den sovjetiske gravkommisjonen var kun opptatt av å få hjemsendt falne soldater og ikke døde krigsfanger. En mulig forklaring på dette er at den sovjetiske kommisjonen ikke hadde fått instrukser angående krigsfangene og antok at dette var norske myndigheters ansvar.

I Karasjok opplyste lensmannen vinteren 1945 at man ikke hadde noen oversikt over hvor mange sovjetiske statsborgere som enten var skutt av tyskerne eller hadde omkommet på annet vis. I dette området var om lag 300-400 ofre gravlagt

53 RA, Krigsgravtjenesten, eske 26-35. «Russiske gravsteder i Finnmark». Notat. Fylkesmannen i Finnmark. Vadsø 31.08.1948.

54 Sør-Varanger Arbeiderblad, udatert november 1949.

55 Ibid.

56 RA, RAFA-2018/D/Da/L0031. Notat, Hærens overkommando, Sentralkontoret for krigsgraver. Tromsø 28.01.1950.

57 RA, Krigsgravtjenesten, eske 26-35. Notat. Oslo 09.10.51. 
i store fellesgraver, men siden gravene ennå ikke var åpnet, hadde man ikke kunnet fastslå ofrenes nasjonalitet. Ifølge lensmannen inneholdt gravene sannsynligvis hovedsakelig jugoslaviske ofre. Sognepresten i Karasjok fortalte at det fantes enkelte spredte graver omkring i distriktet som ikke var åpnet eller undersøkt. I forbindelse med befaringen utført av den britiske War Crime Commision i Karasjok sommeren 1945, ble det bestemt at alle krigsgravene som ble funnet utenfor Karasjok kirkegård, skulle flyttes. Våren/sommeren 1945 sørget en av lensmannsbetjentene for begravelsen av en sovjetisk krigsfange som ble funnet skutt like ved hovedveien på nordsiden av Karasjok. Den døde fangen ble funnet bak en stor stein om lag 50 meter fra en veisprenging nedenfor en bratt bakke og var ikke synlig fra veien. Den høyre armen var bøyd inn mot hodet. Etter klærne å dømme hadde han vært soldat. Liket var dekket av leire og sand fra sprengningen ved funnstedet. Ansiktet på den døde var råtnet og ugjenkjennelig. Alle klærne ble undersøkt for å finne mulige identifikasjonstegn. På innsiden av ytterfrakken var det sydd fast en tøylapp med numrene 6, $34 \mathrm{og}$ 365. Identifikasjonsbrikken var festet til en snor i ytterbuksa. På brikken stod det Stalag 309 nr. 13598. Brikken viste at fangen var registrert i samleleiren Stalag 309 Salla i Finland før han ble sendt til Norge. Betjenten skrev en detaljert rapport om funnet:

(...) Midt på brystet fantes to runde hull ved siden av hverandre, sannsynligvis etter riflekuler. Litt lenger oppe vistes noen skrammer. Ryggen ble ikke undersökt, da vi ikke orket å kle liket helt av. Soldaten hadde värt godt kledd og hadde på seg 1. tykk grönn uniformsfrakk, 1 grönn uniformströye, 1 skjorte av strie, 1 ullgenser, 1 underskjorte, 1 skjerf rundt halsen, 1 ytterbukse, 1 macobukse, 1 grå underbukse, 1 par tyske stövler, 1 par strömper, papirstrie utenpå strömpene, 1 lärbelte rundt livet. Lue manglet, likeså armbånd. En strisekk hengt utenpå frakken inneholdt 6 håndklär, 3 spiseskjeer, 1 underbukse, 1 vott, 1 B-såpe, diverse småsekker. I lommene fantes 2 nye håndklär, 1 spiseskje festet til en snor og bundet fast i frakken, 1 B-såpe, törrede grönnsaker, 1 liten tomsekk, litt skrivepapir, 1 par votter, noen barberblad, 2 bonbons. De fundne gjenstandene ble puttet i trekassen sammen med liket, som ble pakket inn i papir. ${ }^{58}$

Etter ordre fra politimesteren skulle ikke liket bli gravlagt i Karasjok, men sendes til Vadsø. Dette var ikke mulig på grunn av mangel på transportmuligheter og liket måtte gravlegges snarest på grunn av sommervarmen. Liket ble gravlagt i Karasjok, og identifikasjonsbrikken og tøylappen ble sendt til den sovjetiske kommandanten i Kirkenes. ${ }^{59}$

58 RA, RAFA-2018/Da 23 saksarkiv. Politimesteren i Vadsø. «Oppgave over sovjetrussiske borgere som under okkupasjonen er omkommet i Norge». Vadsø 01.02.1946.

Ibid. 


\subsection{Troms og Nordland}

Før den sovjetiske offensiven mot Kirkenes startet høsten 1944 ble store mengder sovjetiske krigsfanger tvunget sørover. Sovjetiske krigsfanger som etter hvert befant seg i Troms, ble sendt ut på marsjer på 30-50 kilometer om natten, og blant dem var det avdelinger som hadde vært på marsj fra Finland og Finnmark i over to måneder. Flyttingen av dårlig utstyrte og utslitte fanger foregikk om natten, fordi tyskerne ville unngå at sivilbefolkningen skulle se fangene marsjere gjennom Nordland fylke. NTBs korrespondent i Narvik rapporterte at de som ikke hadde sett disse kolonnene med halvdøde subbende mennesker, kunne ikke forestille seg det grufulle synet. Under forflyttingen til Narvik måtte krigsfangene ligge ute i bitende kulde. En morgen ankom 800 fanger Salangsdalselva, der de oppholdt seg i flere dager under åpen himmel og i bitende frost. På riksveien nord og sør for Narvik døde mange sovjetiske krigsfanger under marsj. I løpet av sommeren 1945 ble det funnet en del sovjetiske massegraver, og særlig på strekningen Lyngen-Salten var det mange utslitte fanger som mistet livet. I Troms ble det etter en transport funnet fem døde sovjetiske krigsfanger. De var blitt skutt fordi de ikke maktet å holde følge. Et vitne fortalte om 23 sovjetiske ofre som tyskerne hadde gravlagt i en grøft. ${ }^{60}$

På to steder i Øverbygd i Målselv i Troms var det gravlagt 150 sovjetiske krigsfanger, som døde i fangeleiren på Skjold. Ingen av ofrene var navngitt. På Målselv kirkegård var det gravlagt 24 sovjetiske krigsfanger og bare åtte av disse var navngitt. Fem av fangene døde etter å ha spist rottegift. ${ }^{61}$

Lensmennene i samme distrikt rapporterte om en rekke ukjente graver. På kirkegården i Takvatn i Balsfjord var det funnet ni gravlagte sovjetiske krigsfanger, 21 gravlagte på Sagelv kirkegård og en gravlagt utenfor kirkegården. Ingen av de døde var registrert med navn eller fødselsdata. Den tyske divisjonen som hadde vært stasjonert i området, var oppløst, og det var derfor tvilsomt om det var mulig å skaffe informasjon om de døde. Lensmannen i Lyngen rapporterte om den beryktede «dødsleiren» i Kitdalen, hvor mange sovjetiske krigsfanger ble drept. Han nevnte også at det var en del spredte tilfeller av mishandling, sult med døden til følge samt skyting, uten at en kunne si hvor mange som ble drept på denne måten. Det var også helt umulig å skaffe personopplysninger på de drepte krigsfangene. Lensmannen i Karlsøy oppga at en sovjetisk krigsfange var registrert død i dette området, men det ble ikke gitt noen opplysninger om navn eller dødsårsak. ${ }^{62}$

60 Helgeland, onsdag 25.07.1945.

61 RA, RAFA-2018/D/Da/L0023. «Oppgave over sovjetrussiske borgere som under okkupasjonen er omkommet i Norge». Målselv lensmannskontor 30.01.1946.

62 RA, RAFA-2018/Da 23 saksarkiv. Notat, Politimesteren i Troms. Tromsø 30.01.1946. 
Grav 4 .

jk nr. 1. Fangebrikke

43395/314. To papirlapper skrevet ps russisk, lommetorkle, tobakksdßse, pose.tau, knapp av mar ineuniform, belte halsbind, sk.je, lomnekniv, spenner, knapper, spikrer. (kieven av st

2. "Stalag II B 126 975.skje,et treskrin.Tre fortenner iove 3. II B 118 E76. Et kokekar med innrissing 1 lokket 118526

I8576, hansker, russisk sangbok, papirbit, spiseskje, en bakkelittboks, et par skinnhansker 1 \& ved $11 k e t$, en pencepung med sysaker, barberhøvel, paplr ark (muligeas brev) knapper blyant, tréd, lommekniv

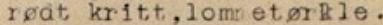

8. " 128514 II B Papir skrevet p\& russisk,kniv, toypose, speil skilue, lommetørkle, lomespeil, hyssing, sipe, knappor, blyant stubb.

5. Om halsen et snere med en knapp 1. Litt papir. Ingen andre kjennetegn.

6. Fangebrikke stalag

II $\mathrm{B} \mathrm{nr}$ : $107183 . \mathrm{En}$ lerrem rundt halsen, tro11 $\mathrm{F}$ brukt til \& dra 11 ket etter.

7. " $309 \mathrm{nr}$. 3028 . Papirbiter, sysaker, blikkeske, sigarettender, blyantstubb, teyoose med papir, barberblad, småsplker.

8. bt ecelagt kokekar. Ingen kjennetegn.

. En liten saks inntullet 1 fotkluten. Ingen ancre kjennetegn.

10. Inger kjennetegn.

1.. $ค$

12. Skje, feltflaske, lerrem, gasbind, tobakkspung, litt smor, taus tumper, belte, sigarettetui, sigarettmennstykke, lerretsduk. Bena snoret sammen med tykk st 1 tria. Ingen andre kjennetegn.

13. Ingen kjenretegn.Sti̊ltr\&a om bena.

14. To lomekniver, pipe, lomeduk, pengepung, barbersaker, papirbiter, sanghefte med noter, tr bُo.

15. Ingen kjennetegn.

16. Fangebrjkke Stalag 12635 (309). Sanghefte, skje,gaffel.Avlang blikkdåsé, pipemunnstykke, spenne, papir, lomriokniv i skoen.

17. Fangebrikke 1 lommen Stalag 30813799

oval om halsen Stalug 340 R.N. 51002 , En sk:e, lomn:etørkje merket p\& russisk, pengepung med noe papir 1 , et relgenbilde av netal lite.

18. Ingen kjennetegn

19. Fangebrikke Stalgg II B 107008 . En halv skje, to pengestykker, stoppenar , sipe. Eundet med lerrem om bens.

20. Io tobakksaiser den ene merket med russiske bokstaver, en notisbok mea skrift p\& russisk.

Liste som beskriver funnene i grav nr. 4. Kilde: Krigsgravtjenesten. RAFA, Da 23. 
De eneste opplysningene politikonstabel Sigmund Leigland i Kvesmenes i Lyngen fant på ofrene i Kitdalen, var fangebrikker med fangenummer på flesteparten av de 104 ofrene i den største graven (grav nr. 1). Han var til stede ved obduksjonen av ofrene i juni 1945 og tok vare på personlige eiendeler som fangebrikker og papirer. Så langt det var mulig, prøvde han å få tydet tegn, tatoveringer og russisk skrift ved hjelp av tolk. Arbeidet var vanskelig og i mange tilfeller var papirene så oppløst at det ikke var mulig å tyde hva som var skrevet. Leigland tok også vare på klær som han mente hadde vært innsatt med bensin, og som ble funnet i grav nr. $4{ }^{63}$

Professor Einar Sjøvall og assistentlege Magne Svendsen fikk en vanskelig jobb med å undersøke 143 sovjetiske ofre i fire graver i Kvesmenes i Lyngen kort tid etter frigjøringen. Undersøkelsen avdekket råskapen og den brutale behandlingen tyskerne utsatte de sovjetiske krigsfangene for. Engelske og amerikanske offiserer som deltok på oppdraget, innrømmet etter arbeidet var ferdig at de hadde bare hørt om slike forbrytelser, men ikke trodd at dette kunne skje her. I den første og største graven fant man likene omtrent 1 1/2 meter under bakken med hodene godt dekket av store bunter med kvister. Det var lagt store steiner og jord oppå de døde, og selve graven var dekket til med gresstorv. ${ }^{64}$

I denne første graven ble det funnet 96 ofre. 79 av disse døde av sult, og 17 var enten skutt eller slått i hjel. De fleste av ofrene som var skutt, ble drept ved ett skudd. Skuddene hadde vært rettet mot nakken, tinningen, halsen eller brystet, i ett tilfelle mot ryggen og i ett tilfelle mot magen. Skuddene var som regel nærskudd, og skadene på ofrene var som regel så store at det var rimelig å anta at skuddet hadde vært løsnet med gevær. En av dem som var skutt, ble funnet med uniformsluen trukket ned for øynene, noe som kunne tyde på at han ble henrettet. I den andre graven med tolv døde, ble det også funnet tegn til en henrettelsessituasjon hvor uniformsluen var trukket ned for øynene på offeret. Et annet av ofrene ble funnet med et skudd gjennom venstre hånd og deretter inn $\mathrm{i}$ hodet gjennom høyre kinn. Fangen hadde trolig sett at våpenet ble rettet mot ham og forsøkt å beskytte hodet med hånden. Alle ofrene i den andre graven døde som følge av ytre vold. Den varme påkledningen på ofrene tydet på at dette var krigsfanger som alle var satt til å arbeide utendørs, og videre undersøkelser avdekket at de hadde dødd ganske tidlig under oppholdet i leiren. Den tredje graven inneholdt to ofre. Legene bemerket særlig at den ene døde var nedgravd, mens den andre lå i en snødrive over jorden. Det ene offeret var fullt påkledd og var drept med et dobbelt nærskudd. Han hadde

63 RA, RAFA-2018/Da 23 saksarkiv. «Rapport til herr politimesteren i Troms avgitt av lensmannen i Lyngen v/hj. politikonstabel Sigmund Leigland». Kvesmenes 22.06.1945. PRO, WO/331/24, 88511. «Rapport til politipresidenten i Tromsø». Tromsø 07.06.1945. 
uniformsluen bak frem og trukket ned foran øynene. Klærne var trukket opp på kroppen slik at brystet var blottet. Situasjonen tilsa enda tydeligere enn tidligere tilfeller at dette var en ren henrettelse. Det andre offeret var også skutt, men uten at situasjonen tydet på en henrettelse. Han var skutt i nakken og gjennom hodet. På grunn av store skader på den døde ble det antatt at skuddet stammet fra et gevær. Fangen har trolig ikke orket å gå lenger underveis til arbeid på fjellet og ikke klart å holde følge. Dermed hadde de tyske vaktene skutt ham. De to dødsfallene skjedde ikke på samme tid, til tross for at begge var skutt og sannsynligvis hadde vært i leiren på samme tidspunkt. I den fjerde graven var det 25 døde. De døde lå fastklemt sammen i graven og var skjøvet inn under hverandre på forskjellig vis. Fra et rettsmedisinsk synspunkt fikk legene inntrykk av at ingen eller bare noen få av de døde hadde noen betydelig grad av dødsstivhet da de ble kastet i graven.

Trolig var alle de døde lagt i graven samtidig siden alle ble funnet fullt påkledd og med samme utrustning av matspann. Likene og klærne var forbrent i større eller mindre utstrekning. Forbrenningen hadde i alle tilfeller funnet sted etter at ofrene var drept. Undersøkelsene av graven viste at samtlige av ofrene var skutt. Ved to tilfeller ble det også konstatert annen mekanisk vold, muligens slag med en geværkolbe. I de fleste tilfellene var ofrene skutt på nært hold i nakken. Ett av ofrene var skutt inn i munnen. Det var av særlig betydning at det utelukkende i denne graven ble påvist skuddskader på armene eller beina på ofrene. Det har også vært tilfeller der fangene ble skutt bakfra og på avstand. Skuddene ga grove splintringsbrudd eller var dødelige på grunn av skade på store blodkar. En slik skuddskade, som ble funnet i fire tilfeller, antydet at fangene var skutt idet de forsøkte å rømme. Undersøkelsene av hele graven viste at dette var en gruppe fanger som åpenbart hadde bevart arbeidsevne, og som ble drept samtidig ved skyting og deretter kastet $\mathrm{i}$ en felles grav. Ofrene ble skutt oppe på arbeidsplassen i nærheten av graven. Etter at de var lagt ned i graven, ble det gjort forsøk på å brenne opp likene. ${ }^{65}$

Ivan Kratshewski overlevde det han beskrev som «dødsleiren i Kitdalen», som lå på fjellet ovenfor Kvesmenes. Leiren ble også kalt «Mallnitz». Han ble sendt til Norge som krigsfange i desember 1944. Den 2. mai 1945 så han en soldat skyte en sovjetisk krigsfange etter ordre fra underoffiser Kruz. Alexei Pochwalow skulle løfte opp en trestamme, men klarte ikke dette. Han ble slått og fikk en ny ordre, men klarte det fortsatt ikke. Soldaten vendte seg til Kruz og sa at Pochwalow var lat. Kruz svarte: «Skyt ham.» Soldaten skjøt på nært hold med rifle og traff like under øyet. Pochwalow falt, men døde ikke. Han skjøt nok en gang, denne gangen gjennom pannen. Soldaten som

${ }_{65}$ RA, Krigsgravtjenesten, eske 26-35. «Et makabert 20-årsminne. Noen krigsfangegraver i Nord-Norge». Av Magne Svendsen. Udatert. 
skjøt, het Hermann. Kratshewski stod like ved og så det hele. Pochwalow ble liggende til neste dag, da han ble begravd. Inntil 17. april hadde forholdene vært noenlunde greie i leiren, uten døde eller syke. Etter dette forandret alt seg. Nye fanger kom til, og kun en del av det gamle kompaniet ble igjen. Dødstallene steg kraftig, og likene ble etter hvert begravd i en stor grav som tyskerne kamuflerte med stein og torv. Det var fra dette tidspunktet at leiren fikk navnet «dødsleiren». I leiren på Kvesmenes døde 20 krigsfanger av tyfus mens Kratshewski var der. Den sovjetiske tolken, obergefreiter Jaschinski, fortalte ham at ingen ville komme ut av leiren i live. Selv ble han ikke utsatt for mishandling, men han var vitne til at de tyske vaktsoldatene Teubel, Bachenstoss, Kurz og Staib mishandlet fangene. De slo dem med hva de måtte ha for hånden. ${ }^{66}$

Et annet vitne som overlevde «dødsleiren», var Iwan Duchanin. Han ankom leiren i slutten av april 1945. Duchanin fortalte at alle fangene bar fangenummeret $\mathrm{i}$ et kjede om halsen. Når en fange døde, ble merket med fangenummeret delt $i$ to og den ene halvdelen ble værende på liket. Den andre halvdelen av fangemerket ble oppbevart av tyskerne. Han var vitne til at en syk krigsfange ble skutt fordi han ikke klarte å gå. Underveis til arbeid så han ofte lik liggende i området. En dag var han også vitne til at en oberfeldwebel slo en fange så han måtte sendes på hospitalet, hvor fangen senere døde av skadene. ${ }^{67}$

I slutten av juli 1945 tegnet løytnant Haukøy to forslag til et monument ved en sovjetisk fellesgrav i Kvesmenes. Haukøy hadde jobbet som tolk under den norsk-sovjetiske undersøkelseskommisjonens arbeid i Kvesmenes. Major Dycker ved Forsvarets distriktskommando i Tromsø kontaktet Distriktskommando Nord-Norge angående spørsmålet om monument for gravene. Han oppga at graven hadde ikke mer enn ca. 200 døde, men hvis "Civil affairs» (britisk avdeling for undersøkelser av krigsforbrytelser i Norge) fikk avsluttet sine undersøkelser og frigitt resultatet, ville graven muligens bli forholdsvis godt kjent. Dycker oppga også at den sovjetiske diplomaten Velja, som var med i kommisjonen, hadde sagt at det var ønskelig med et kors på hver av de fire fellesgravene som gravstedet i Kvesmenes bestod av. Han foreslo at tegningene over monumentet ble sendt til biskopen i Hålogaland, Wollert Krohn-Hansen. ${ }^{68}$ Ved Distriktskommando Nord-Norge (DKN) var det enighet om at det burde bli reist et minnesmerke på gravplassen i Kvesmenes, men før dette ble avklart, var det ønskelig å få full oversikt over hvor mange monumenter over gravlagte sovjetiske statsborgere det kunne bli spørsmål

66 PRO, WO/331/24, 88511. Notat, Politimesteren i Troms. Tromsø 08.06.1945.

${ }_{67}$ RA, RAFA-2018/D/Da/L0023. «Rapport fra statsadvokaten i Troms og Finnmark». Tromsø 08.06.1945.

68 RA, DKN, 316 krigsgraver i Nord-Norge. Brev fra Major Dycker til D.K.N. «Monument til Russisk fellesgrav i Kvesmenes». 25.07.1945. 
om innen DKNs område. Hvis det var staten som skulle ta kostnadene for dette, foreslo de at det ble laget en plan for en ensartet og enkel utførelse av dette arbeidet. ${ }^{69}$ Biskop i Hålogaland, Wollert Krohn-Hansen, sa seg enig i konklusjonen angående minnesmerkene. Han påpekte også at saken burde bli lagt frem for Hålogaland stiftsdireksjon når det var tatt en avgjørelse i saken. Korrespondansen om mulige minnesmerker stoppet opp, og det ble ikke laget noen monumenter basert på tegningene som var presentert. Senere, under oppgravingen av ofrene i Kvesmenes-området i 1951, ble det opplyst at både tremonument og kors var fjernet på grunn av råte. Det eksakte antallet ofre i dette området er vanskelig å fastsette. Noen år etter frigjøringen fastslo Forsvaret at det var så mange som 300 sovjetiske ofre i Kvesmenes og $120 \mathrm{i}$ Kitdalen. ${ }^{70}$

I Senja politidistrikt var det et høyt antall anonyme graver i 1945. Tre ukjente sovjetiske krigsfanger som ble skutt av tyskerne i 1942, lå gravlagt på Kvefjord kirkegård, og på Holm kirkegård var det gravlagt en ukjent sovjetisk krigsfange som var drept med et nakkeskudd. På de større gravstedene i distriktet var 70 fanger gravlagt på Straumen kirkegård i Sørreisa, fire fanger på Elvevoll i Salangen, 104 fanger i Bardu herred og 397 fanger ved Trondenes kirke. Navn og dødsårsak på disse stedene var det ikke mulig å skaffe. Antallet ofre var oppgitt av tyskerne og ifølge politiet på Senja var det bare mulig å skaffe «Erkennungsnummer» (fangenummer) på de døde. ${ }^{71}$ Nordmenn ble vitner til hvordan krigsfangene måtte bære sine døde medfanger. I januar 1945 ble 14 døde sovjetiske krigsfanger fraktet i land fra et tysk transportskip på kaia i Sørreisa i Tranøy. Lensmannen hadde fått melding om de døde, og ble fortalt at dette var krigsfanger som hadde mistet livet underveis fra Bardufoss til Sørreisa. De døde ble liggende på kaia til neste dag. Lensmannen oppholdt seg i et hus et stykke unna for å følge med på hva som ble gjort med ofrene. Etter hvert kom det flere sovjetiske krigsfanger, som begynte å slepe de døde bort fra kaia. Under bevoktning av tyske soldater måtte krigsfangene slepe sine døde kamerater til et gravsted ca. 100 meter fra kaia. Da de var kommet opp på veien, passerte lensmannen fangene. De hadde tau om beina og tre til fire sovjetiske krigsfanger dro hvert lik. Trøyene til de døde var blitt slitt delvis av under slepingen, så lensmannen kunne tydelig se de bare og magre overkroppene. De døde var fryktelig tynne. Han kunne ikke se noe tegn til skudd, men et av ofrene hadde et mindre sår over nesen. Krigsfangene som var satt til dette uhyggelige arbeidet, hadde tårer i øynene, og de så på

${ }_{69}$ RA, DKN, 316 krigsgraver i Nord-Norge. «Monument på det russiske gravsted på Kvesmenes». Tromsø 26.07. 1945.

70 SAT, Distriktskontoret for krigsgraver i Trondheim. «Flytting og sammendragning av krigsgraver i Norge». Hærens Overkommando. Oslo 19.12.1949.

71 RA, RAFA-2018/Da 23 saksarkiv. Notat, Politimesteren i Senja. Harstad 18.12.1945. 
Før tyske soldater ble hjemsendt, ble de satt til å grave opp ofrene for tyske krigsforbrytelser. I oppgravingsarbeidet i Nordland ble tyske soldater brukt som arbeidskraft, og arbeidet var ikke like enkelt alle steder. Tyskerne var uønsket av befolkningen, så det ble problematisk å få innkvartert soldatene.

Kort tid etter frigjøringen kontaktet sognepresten i Brønnøysund biskopen i Hålogaland for å få 22 sovjetiske graver flyttet så raskt som mulig. Gravene var samlet på ett sted, men på grunn av en bekk i utkanten av gravstedet antok sognepresten at samtlige ofre lå gravlagt i grunnvannet. Gravstedet måtte betegnes som en myr. Når det regnet, flommet vannet over de gravene som lå nærmest bekken. Sognepresten påpekte at det var svært viktig for en verdig flytting at den foregikk før høstregnet startet. Lokalbefolkningen opplyste at noen av de gravlagte fangene døde av mishandling. 21 av gravene hadde kors med fangenummer, og i graven uten kors lå det en sovjetisk krigsfange som var skutt under et rømningsforsøk. Etter at han var skutt, ble han liggende på retterstedet $\mathrm{i}$ en dag til skrekk og advarsel for de andre fangene. ${ }^{74}$

1. Norske Brigade hadde 21 tyske menn til disposisjon i arbeidet med flyttingen av graver. Distriktskommando Nord-Norge ga i september beskjed til avsnittskommandoen i Mosjøen at den tyske troppen kunne settes i arbeid med flytting av graver ved behov. Gravene som var aktuelle for flytting på dette tidspunktet, var gravene i Brønnøysund, seks til syv britiske graver på Hemnesberget, to serbiske på Ylvingen i Vega og syv sovjetiske graver på Selnes i Lurøy. Det ble også påpekt at flyttingen burde skje etter anvisning fra vedkommende sogneprest, og fortrinnsvis til ordinær kirkegård eller en egen krigskirkegård. ${ }^{75}$

De syv gravene på Selnes var plassert i nærheten av festningsanlegget på Grønsvik fort. Gravene lå langt fra bebyggelsen i området. På gravstedet var det satt opp en sokkel av sement og et gresk-katolsk kors med denne innskriften på russisk: «Syv russiske soldater, faldt for tysk, fascistisk-nasistisk terror». ${ }^{76}$ Hvis gravene skulle flyttes, ønsket sognepresten i Lurøy at de ble flyttet til kirkegården for distriktet, som var Haugland i Aldersund. Flyttingen av de sovjetiske ofrene i dette området var ikke en prioritert sak, og i desember 1945 rettet sognepresten en ny henvendelse til Distriktskommando NordNorge. Han påpekte at det var en voksende misnøye blant lokalbefolkningen på Mosheim i Brønnøy på grunn av at de 22 sovjetiske gravene ikke var flyttet til en innviet kirkegård. Sjefen for den norske vaktbataljonen i Brønnøysund hadde gitt lovnader om at flyttingen skulle ordnes ved hjelp av tyske mannska-

74 RA, DKN, 316 krigsgraver i Nord-Norge. «Samling av spredte krigsgraver». Brønnøysund 17.08.1945.

75 RA, DKN, 316 krigsgraver i Nord-Norge. Telegram fra Distriktskommando NordNorge til avsnittskommando Mosjøen. 24.09.1945.

76 RA, DKN, 316 krigsgraver i Nord-Norge. «7 russiske graver på Selnes i Lurøy». Lurøy 12.09.1945. 
per i november, men ingenting hadde skjedd. Gravene stinket om sommeren, og bekken var helsefarlig for husdyrene som beitet i nærheten. Hvis det var umulig for Forsvaret å ordne saken, mente sognepresten at det helt sikkert var en del unge menn som frivillig ville hjelpe til med oppgraving og transport, hvis militæret stilte transportmidler til rådighet. Sognepresten ønsket svar på om de kunne regne med å få hjelp fra Forsvaret. Det var valgt ut en egnet plass for gravene på kirkegården, og om lag $1000 \mathrm{kr}$ var samlet inn til pynting av gravene. I den forbindelse ønsket sognepresten å få vite om det fantes egne retningslinjer for utsmykning av sovjetiske graver. ${ }^{77}$ Det er ingen dokumenter som tyder på at sognepresten fikk noe svar på spørsmålet angående utsmykningen av gravene.

Før den tyske gravekommandoen kunne sendes på oppdrag, var det flere spørsmål som måtte avklares. Distriktskommando Nord-Norge ønsket svar på om hva slags transportmidler som krevdes ved oppdraget, hvor langt og hvor likene skulle transporteres og til slutt om det fantes passende innkvartering for den tyske arbeidsstyrken. ${ }^{78}$ Sognepresten i Brønnøy svarte at de hadde behov for en lastebil. I tillegg måtte man ha hest og slede for å transportere likene til veien. Nåværende gravsted lå om lag 200-300 meter fra veien, og transporten langs veien til Brønnøy kirkegård var om lag 4,5 kilometer lang. Når det gjaldt innkvartering, lå ungdomshuset beleilig til, ifølge sognepresten. ${ }^{79}$ Det viste seg imidlertid at ungdomshuset var for lite for den tyske gravekommandoen på 16 mann med utstyr. Sognepresten i Brønnøy tok kontakt med sjefen for sivilforvaltningen for å undersøke om det var mulig å låne en av brakkene i Brønnøysund til innkvartering av tyskerne. Han fikk til svar at byens formannskap ikke ville ha tyskerne i byen. Sognepresten fikk da beskjed om snarest å ordne innkvartering, eller sende tyskerne tilbake til Tromsø. Saken løste seg likevel ved at ordføreren i Brønnøysund ordnet med en brakke som var stor nok til det tyske mannskapet. ${ }^{80}$

Oppgravingsarbeidet i Brønnøy startet i april 1946. Stedets lensmann og distriktslege var varslet om arbeidet, og skulle undersøke de oppgravde ofrene for å se om de hadde merker etter skudd eller brudd. På grunn av økt vannstand på gravplassen etter snøsmelting ble arbeidet med oppgravingen utsatt etter kort tid. ${ }^{81}$ Arbeidet ble satt i gang igjen, og i slutten av april ble fire sov-

77 RA, DKN, 316 krigsgraver i Nord-Norge. «22 russiske fangers graver». Brønnøysund 11.12.1945.

78 RA, DKN, 316 krigsgraver i Nord-Norge. "Ad. Russiske fangegraver». Distriktskommando Nord-Norge. Tromsø 28.01.1946.

79 RA, DKN, 316 krigsgraver i Nord-Norge. «Sognepresten i Brønnøy». 10.02.1946.

80 RA, DKN, 316 krigsgraver i Nord-Norge. «Rapport nr. 1, tysk arbeidskommando». Brønnøysund 27.03.1946.

81 RA, DKN, 316 krigsgraver i Nord-Norge. «Rapport nr. 2, tysk arbeidskommando». Brønnøysund 06.04.1946. 
Figenschow til planene om oppgraving på Lurøy, Mo i Rana og Hemnes. Han påpekte på nytt at det var behov for mer arbeidsmannskap for å få ordnet krigsgravene før sommeren. ${ }^{84}$ Det ble ikke tildelt mer tysk mannskap til oppgravingsarbeidet på Helgeland, og samme gravekommando fortsatte med arbeidet på de andre stedene.

Etter at arbeidet i Brønnøysund var ferdig, uttrykte sognepresten sin takknemlighet for arbeidet som var utført, og han rettet en særlig takk til Distriktskommando Nord-Norge som fikk satt i gang arbeidet. De hadde imidlertid fått en regning fra kommunen angående innkvarteringen av den tyske gravekommandoen, og denne ble returnert. Sognepresten mente at dette var uforståelig siden det var Distriktskommando Nord-Norge som hadde tatt initiativet til at de sovjetiske krigsgravene skulle flyttes. Sognepresten kunne ikke se at det økonomiske ansvaret for dette arbeidet skulle legges på kommunene. Han viste til at distriktskommandoen kunne sende en søknad til Brønnøysund kommune hvor de ba om å slippe husleieutgiftene for brakken. ${ }^{85}$ Det oppgis ikke hvem som til slutt måtte dekke disse utgiftene, men det var åpenbart at Forsvaret ville unngå at arbeidet ble for kostbart.

${ }^{84}$ RA, DKN, 316 krigsgraver i Nord-Norge. «Rapport nr. 6, tysk arbeidskommando». Brønnøysund 11.05.1946.

85 RA, DKN, 316 krigsgraver i Nord-Norge. «Russergravene. Sognepresten i Brønnøy». Brønnøysund 12.06.1946. 
Gravekommandoen skulle etter planen fortsette arbeidet med oppgraving av sovjetiske, polske og serbiske ofre i Bjerka, Korgen, Korgfjellet og Vesterfjellet. Senere skulle den flyttes til Dunderlandsdalen ovenfor Mo i Rana. Distriktskommando Nord-Norge opplyste at det var mange graver i disse områdene, og at man derfor hadde behov for et betraktelig antall kister til dette arbeidet. De var opptatt av at dette kom til å bli kostbart, og for å spare penger foreslo de at ved gravplassene som lå langt fra tettbebyggelse, skulle kistene tømmes i de ferdiggravde gravene og brukes flere ganger til transport. Ifølge opplysninger fra sognepresten i Mo i Rana var dette en fremgangsmåte som var blitt brukt ved oppgraving av ofre sommeren $1945 .{ }^{86}$ Samlingen av gravene i dette området var åpenbart kostbart og tidkrevende for Forsvaret. Den tyske gravekommandoen var ferdig med arbeidet i begynnelsen av september 1946 og ble deretter sendt til Oslo.

I Lødingen engasjerte sognepresten seg i arbeidet med de sovjetiske gravene i prestegjeldet. Den tyske sersjanten som hadde ansvaret for nedgravingene, oppga at antallet døde var 37. De døde nokså raskt etter hverandre, angivelig av en epidemisk sykdom. Sognepresten mente det var grunn til å tvile på riktigheten av disse opplysningene, siden dødsfallene hadde funnet sted høsten og vinteren 1941-42 da fangeforholdene hadde vært svært dårlige. Kort tid etter kapitulasjonen hadde sognepresten kontaktet de alliertes offiser, løytnant Iversen, og foreslått at tyskerne ble satt til å planere gravplassen hvor de sovjetiske ofrene lå. Menigheten ville ta på seg ansvaret for å pynte området. Løytnanten opplyste at det ville komme en alliert kommisjon og ta seg av gravene. Sognepresten reagerte på at det fremdeles ikke var gjort noe med hensyn til de sovjetiske gravene i slutten av august 1945. Menigheten hadde samlet inn penger til pynting av gravplassen og til minnesmerker over samtlige falne og døde allierte soldater i Lødingen. Sognepresten foreslo at det ble opprettet og innviet en kirkegård for de sovjetiske ofrene, der gravene lå. Han mente også at hvert lik burde graves opp slik at dødsårsaken for hvert offer kunne bli kontrollert. På dette tidspunktet hadde alle tyskerne reist fra Lødingen, så en eventuell oppgraving måtte gjøres av tyskere fra andre forlegninger. ${ }^{87}$ Det ble ikke oppgitt hvorvidt ofrene ble gravd opp i august 1945 for å undersøke dødsårsakene.

Det var ikke alltid en fordel med den tyske arbeidshjelpen. Angånde gravplassen på Brennhei krigskirkegård ble det opplyst at tyskerne skulle foreta en samling av enkeltgraver fra ulike steder i området. Resultatet ble at de ganske

86 RA, DKN, 316 krigsgraver i Nord-Norge. «Rapport nr. 10, tysk graverkommando». Brønnøysund 02.07.1946.

87 RA, DKN, 316 krigsgraver i Nord-Norge. Lødingen prestegjeld. «Ad. savnede mannskaper og offiserer og mannskaper fra den britiske marine og samling av spredte krigsgraver». Lødingen 29.08.1945. 
enkelt gravde opp de jugoslaviske ofrene som til da var gravlagt på Brennhei, og samlet dem i en stor fellesgrav for å skaffe plass til de sovjetiske ofrene som ble funnet. Kaptein Arntzen ved Krigsgravtjenesten opplyste i 1950 at det var gravlagt 200 sovjetiske og 80 serbiske døde på Brennhei krigskirkegård. ${ }^{88} \mathrm{I}$ årene 1945-48 var det meningen å flytte krigskirkegårdene på Nabbvoll og Bolna til Brennhei, men disse ble flyttet senere i forbindelse med «Operasjon asfalt».

I tilknytning til flyttingen av gravene til nye kirkegårder oppstod det problemer med merking av gravene. Carsten Larsen fra Distriktskommando NordNorge påpekte i 1945 at det var en uopprettelig feil at man samlet de døde i en ny massegrav på en felleskirkegård og etterpå ikke visste noe mer enn antallet på dem som lå gravlagt der. Han viste til et eksempel hvor den ansvarlige områdesjefen for overflytting av graver kun visste antallet på de døde. Kun en liten kvadratisk jordvoll markerte den nye graven på kirkegården. Ofrene lå gravlagt utenfor markeringen, og det var ikke mulig å kartlegge hvor den enkelte lå. Ved et besøk av en sovjetisk major på inspeksjonsreise hadde områdesjefen fătt

88 RA, DKN, 316 krigsgraver i Nord-Norge. «Liste over serbere gravlagt på Brennhei krigskirkegård, Nord-Rana Herred, Nordland fylke». Tromsø 14.05.1950. 
inntrykk av at det skulle være slik. Majoren mente at det ikke var så nøye. Larsen mente at denne holdningen skyldtes at arbeidet med flyttingen av gravene var lagt $\mathrm{i}$ hendene på tilfeldige personer, med vilkårlige eller ingen oppfatning av sakens natur. Dette resulterte $\mathrm{i}$ at det forberedende arbeidet ikke hadde hatt noen hensikt. Larsen viste til distriktssjef Johnsons forslag og direktiver for flyttingen av gravene, som skulle være kjent for både Distriktskommando Nord-Norge og Brigaden. Overflyttingen av gravene var et krevende arbeid, og det var viktig at direktivene for arbeidet var kjent for områdesjefene. Det ble gjort noen endringer, ifølge den opprinnelige planen, ved at gravene i Aspfjord ble flyttet til Øyrvik og Sørfjordmoen ble beholdt som kirkegård. Til Botn kirkegård var det flyttet 110 sovjetiske og 75 serbiske døde. På Hestbrinken kirkegård var det gravlagt 693 sovjetiske krigsfanger. Overføringen av ofrene i dette området ble gjennomført under streng kontroll, og sognepresten hadde journalført hver enkelt grav. Felleskirkegården var velordnet, og korsene som markerte gravene, var planmessig regulert. En egen journal var laget for at man skulle kunne finne den dødes data så langt disse var kjent. ${ }^{89}$

Elleve serbiske døde ble flyttet til Hestbrinken krigskirkegård i Saltdal i 1945. Ifølge opplysninger fra 1 . Norske Brigade var de serbiske fangene skutt av sine medfanger etter frigjøringen på grunn av angiveri i krigsårene..$^{90}$ Alle gravene på Hestbrinken var i 1945 markert med hvite kors og var et verdig gravsted for ofrene. 207 av ofrene var fra leiren Bjørnelva og 133 fra leiren i Krokelva. Svært mange av gravene var opprinnelig ikke merket, og dette var særlig tilfelle ved gravplassen ved Bjørnelva leir på Saltfjellet.

Ved hjelp av fangekortene fra Bjørnelva leir, som nylig er funnet, har det vært mulig å kartlegge navnene på 94 døde krigsfanger som tidligere var ukjente. Disse fangekortene gir dessuten svært detaljerte opplysninger om både fangeleiren og gravstedet som var plassert om lag en kilometer fra leiren.

På enkelte graver var det i 1945 bare oppført et fangenummer, og på andre var det både navn og fangenummer. På noen få graver var det oppgitt navn, fødselsdag, dødsdag og fangenummer. På gravplassen ved leiren Krokelva var det oppført 80 navn på store treplater ved siden av gravplassen, og de enkelte gravene var ikke merket. På gravplassen i Rusånes lå ofrene oppå hverandre i en fellesgrav, og alle navnene var skrevet på en tavle som stod på gravplassen. På grunn av dette var det vanskelig å merke alle gravene etter at de ble flyttet til Hestbrinken krigskirkegård..$^{91}$

89 RA, DKN, 316 krigsgraver i Nord-Norge. «Rapport over arbeidet med overføringen av krigsgraver». Den Norske Brigade. Bodø 14.09.1945.

90 RA, DKN, 316 krigsgraver i Nord-Norge. «Rapport over arbeidet med overføringen av krigsgraver». Den Norske Brigade. Bodø 14.09.1945.

91 Kirkekontoret i Saltdal, «protokoll for krigskyrkjegarden på Hestbrinken ved Storjord i Saltdal». Ved sokneprest L.M. Vågdal, Saltdal, udatert 1946. 


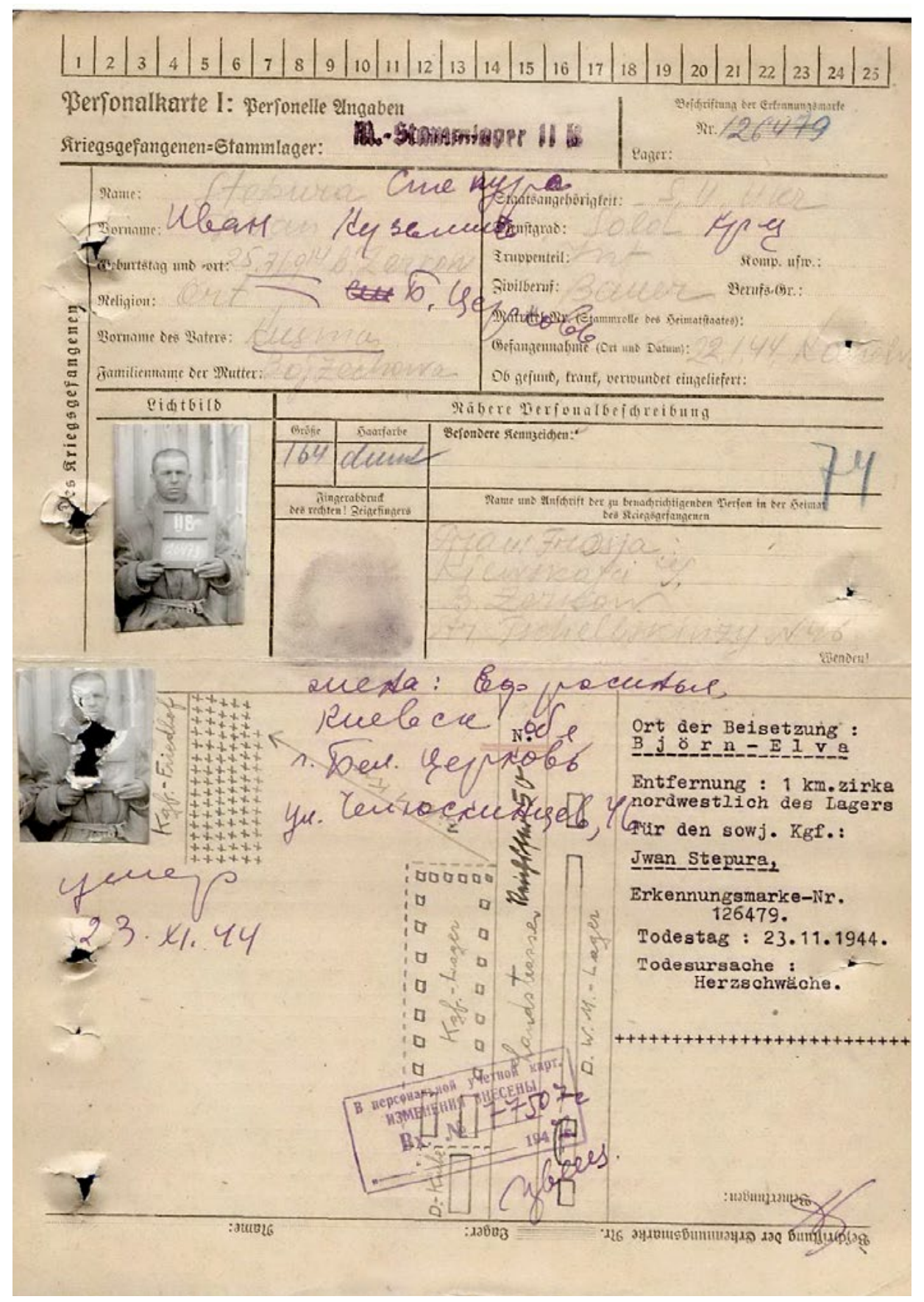

Fangekort, sovjetisk krigsfange gravlagt ved Bjørnelva leir. Bilde av fange, stedsnavn, beskrivelse av gravstedets beliggenhet i forhold til fangeleiren, fangenummer, dødstidspunkt og dødsårsak. Leir og gravsted er beskrevet med tegning på fangekortet. Foto: www.obd-memorial.ru. 
Allerede 20. mai 1945 ringte major dr. A. Johnson fra Bodø, som da var sjef for hjemmestyrkene i den sørlige delen av Nordland fylke, til sogneprest Vågdal i Saltdal. Majoren ba sognepresten etablere en nemnd sammen med distriktslegen og ordføreren, som skulle starte arbeidet med samling av alle fangegravene i dalen til en eller to store gravplasser. Det var kommet inn meldinger til majoren om at det var mange fangegraver i området, og at mange av gravene var i en slik tilstand at de var helsefarlige for både folk og dyr. I Saltdal var det i løpet av det siste krigsåret om lag 12-14 fangeleirer med om lag 15000 krigsfanger i dette distriktet. Ved omtrent hver eneste leir, fra langt inne på Saltfjellet til Setså ute ved fjorden, lå det en gravplass. Vågdal antok at var om lag 1200-1300 døde krigsfanger i dette området. Dette omfattet både sovjetiske og jugoslaviske døde krigsfanger. De jugoslaviske ofrene var stort sett gravlagt i massegraver. Det ble planlagt to store gravplasser, en ved Storjord (Hestbrinken) og en i Botn utenfor Rognan. Gravene i området fra Saltfjellet til om lag midt i bygda ved Pothus skulle samles på Storjord, og gravene fra Pothus frem til Rognan og ute fra grendene ved forden skulle samles ved gravplassen på Botn. Gravplassen som var planlagt i Botn, ble laget slik at disse massegravene kom til å ligge inne på gravplassen, med enkeltgravene til serbiske og sovjetiske ofre plassert omkring massegravene. Vågdal ledet arbeidet med hjelp av norske militære vakter. Han synes arbeidet var nifst og uhyggelig. Likevel var han glad for å få gjøre ofrene en siste tjeneste ved å føre levningene deres i kristnet jord. ${ }^{92}$

I Mosjøen-området ble gravene samlet i Knutlien (Osen), Mosjøen og Hattfjelldal. Dr. Borgen hadde ansvaret for overflyttingen av de serbiske gravene til Knutlien kirkegård. Overflyttingen av de sovjetiske gravene til Mosjøen kirkegård var gjennomført etter planen, og den sovjetiske kirkegården ved Hattfjelldal var ytterligere utbedret. Dermed var samtlige overflyttinger og endelig gravlegging i den sørlige delen av Nordland fylke gjennomført, og de tidligere gravstedene var desinfisert og slettet. ${ }^{93}$

Når det gjaldt gravene i Mosjøen, sendte sognepresten en orientering til biskopen i Hålogaland om samling av spredte graver. En representant fra Distriktskommando Nord-Norge, ordføreren, lensmannen og sognepresten hadde vært på befaring for å undersøke forholdene omkring gravene. Det ble bestemt at en fellesgrav med 18 sovjetiske ofre på Kipermoen og en grav med tre sovjetiske ofre på Trofors skulle flyttes til Mosjøen kirkegård. Arbeidet med å ordne gravplassen var startet og flyttingen kunne gjennomføres så snart som mulig, mente sognepresten. Andre graver visste han ikke om i dette distriktet,

92 RA, DKN, 316 krigsgraver Nord-Norge. «Ad samling av fangegraver i Saltdal». Saltdal 10.08.1945.

93 RA, DKN, 316 krigsgraver i Nord-Norge. «Rapport avgitt av Carsten Larsen». Rognan 30. september 1945 . 


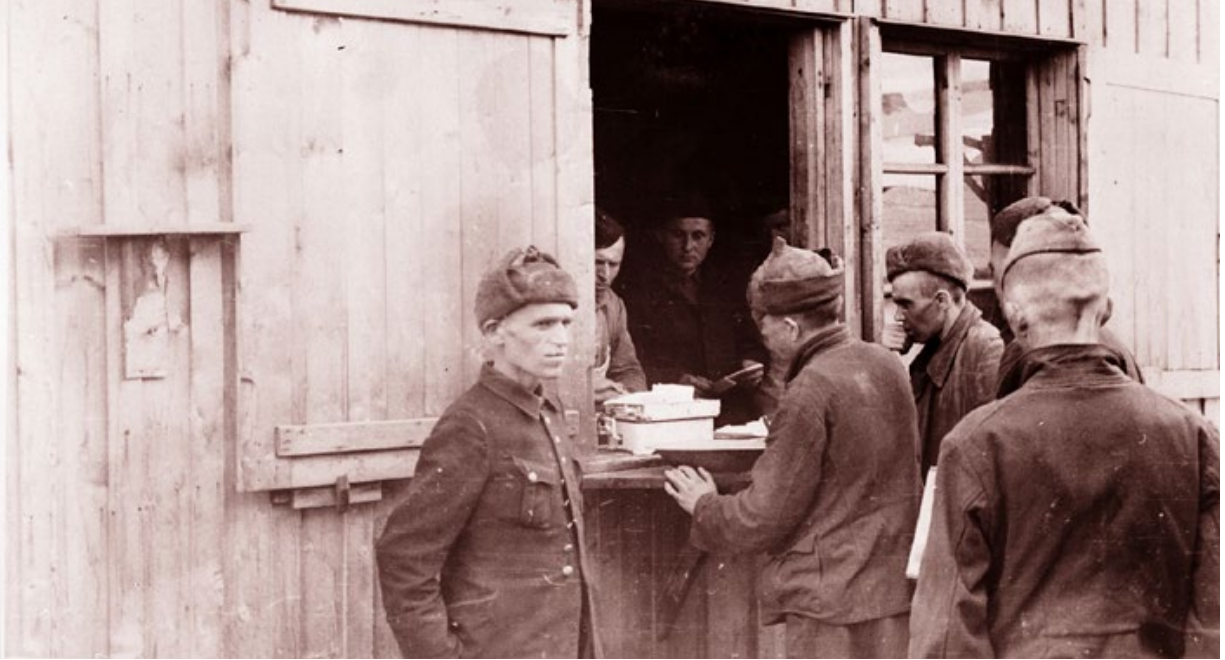

Sovjetiske krigsfanger, Saltdal 1945. Arkiv: Falstadsenteret.

bortsett fra den store sovjetiske kirkegården på Drevjamoen, hvor det antagelig var gravlagt 200 russere. Denne kirkegården mente han det ikke var nødvendig å gjøre noen endringer på, men det var et behov for å pynte den noe mer. I tilknytning til kirkegården på Drevjamoen spurte sognepresten biskopen om det forelå planer om å innvie denne ved noen anledning, men på samme tid antok han at dette kanskje var unødvendig siden det ikke skulle gravlegges flere der. Sognepresten var også opptatt av de tyske gravene på Mosjøen kirkegård. Han var skeptisk til hvordan tyskerne hadde brukt kirkegården. Tyskerne hadde drenert ut et stort område og holdt fortsatt på med gravlegging sommeren 1945. Sognepresten påpekte i notatet at tyskerne brukte stor avstand mellom hver grav og utsmykket plassen nærmest som en æresplass. ${ }^{94}$ Det er ingenting som tyder på at kirkegården på Drevjamoen ble innviet på dette tidspunktet. Gravene ble senere flyttet til Tjøtta krigskirkegård.

I Hattfjelldal rapporterte sognepresten i september 1945 om krigsgravene i området. I dette området befant det seg ikke spredte enkeltgraver, her var 27 sovjetiske krigsfanger gravlagt ved en tidligere fangeleir. Han hadde kontaktet tyske myndigheter for å få opplysninger om de gravlagte, men de kunne ikke gi noen navneliste eller oppgi dødsårsak for de sovjetiske ofrene. Ifølge opplysninger fra tyskerne døde 25 av krigsfangene i tiden 10.10.1944 til 10.5.1945. For to av ofrene var det ikke mulig å fastsette dødstidspunktet. Tyskerne oppga at gravene lå bak potetkjelleren ved leiren som hadde vært underlagt Organisation Todt i Hattfjelldal. Distriktslegen hadde undersøkt gravplassen og mente at det var fullt forsvarlig å la gravene bli liggende. Sognepresten ga tyskerne beskjed om å ordne med inngjerding av gravplassen, og kunne si seg fornøyd med arbeidet da dette var ferdig. ${ }^{95}$

94 RA, DKN, 316 krigsgraver i Nord-Norge. «Ad. rundskriv nr. 41945 fra Hålogaland biskop». Mosjøen 08.08.1945.

95 RA, DKN, 316 krigsgraver i Nord-Norge. «Krigsgraver i Hattfjelldal». Sognepresten i Hattfjelldal. Hattfjelldal 16.08.1945. 
Det virker litt merkelig at sognepresten oppga at tyskerne ikke kunne oppgi dødsårsak for de sovjetiske krigsfangene. Kort tid før han utarbeidet sitt notat om gravene, mottok sognepresten en oversikt fra den tyske løytnanten i Hattfjelldal over dødsårsaker for 25 av de 27 sovjetiske ofrene. I oversikten ble det oppgitt at 21 krigsfanger døde av utmattelse, en døde i en ulykke, en døde av tuberkulose og to var skutt. ${ }^{96}$ En mulig forklaring er at sognepresten hadde behov for en mer detaljert forklaring på dødsårsakene enn hva tyskerne kunne oppgi. I 1947 skrev han til Sentralkontoret for krigsgraver om krigskirkegården i Hattfjelldal. Han viste til at kirkegården ble innhegnet av tyskerne sommeren 1945 etter ordre fra norske militære myndigheter. Tyskerne ble også beordret til å sette opp et minnesmerke over de døde krigsfangene. Sognepresten gjentok at han ikke kunne skaffe noen opplysninger om de døde krigsfangene. ${ }^{97}$ Fremdeles står det originale minnesmerket på gravplassen i Hattfjelldal, men gravene er flyttet til Tjøtta.

Sognepresten i Folda (Sørfold) mente at det ikke var mulig å flytte alle gravlagte sovjetiske og polske ofre i Sørfold til innviede kirkegårder. Plasshensyn ville umuliggjøre dette, og det ville være unødvendig å grave opp mange av kirkegårdene med disse ofrene da gravstedene var godt vedlikeholdt. Sognepresten mente at kirkegården som lå på Kobbvatn, burde bli innviet. Gravstedet lå svært avsides til og en eventuell flytting ville bli veldig tungvint. Han fremhevet at kirkegården var meget vakkert stelt, forsvarlig inngjerdet og ikke til sjenanse for noen. På grunnlag av disse forholdene mente sognepresten at det var helt hensiktsløst å flytte kirkegården fra Kobbvatn. En løytnant fra hjemmestyrkene hadde besøkt Kobbvatn i forbindelse med en planlagt flytting av gravene i Sørfold. Han mente at alle gravene måtte samles på ett eller to steder $\mathrm{i}$

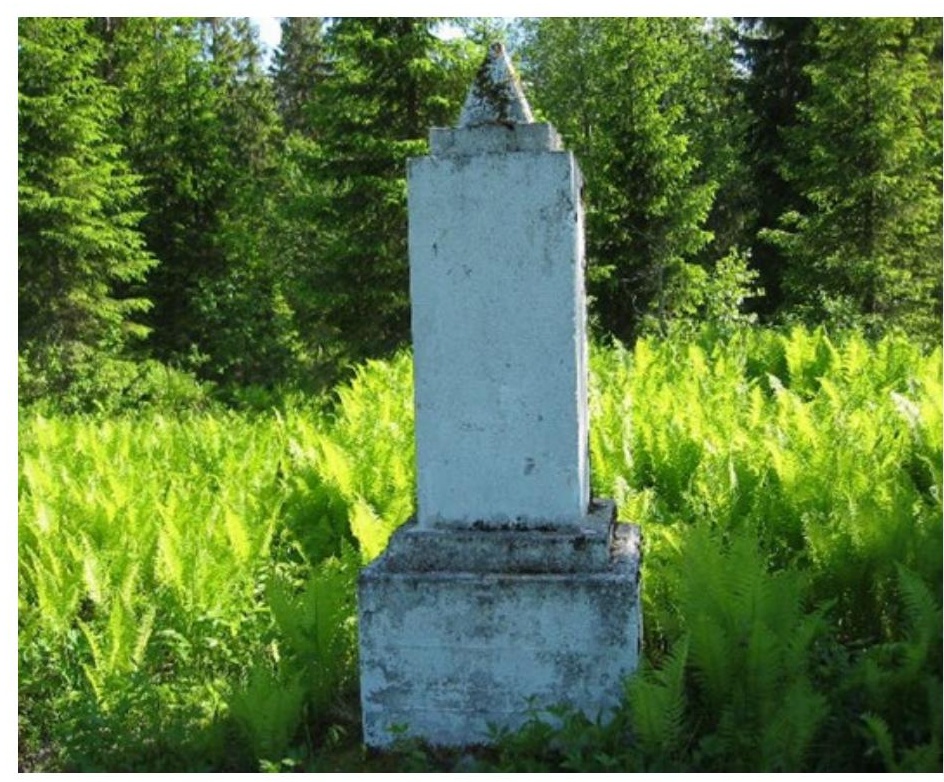

Krigsminnesmerke på Drevjamoen i dag, ikke vedlikeholdt og inskripsjonen er borte. Foto: Forsvarsmuseet Oslo.

96 RA, DKN, 316 krigsgraver i Nord-Norge. Notat. Hattfjelldal 11.08.1945.

${ }_{97}$ RA, RAFA-2018/D/Da/L0024. «Utenlandske statsborgere begravet i Norge under okkupasjonen 1940-45». Hattfjelldal den 14.01.1947. 
bygda. Etter dette besøket hadde ingenting skjedd, og sognepresten hadde tidligere bedt hjemmestyrkene om å flytte graver fra Storvik til Kroken ved tysk hjelp, men dette ble ikke gjort. Han påpekte at norske militære myndigheter måtte avklare eventuell flytting med nødvendig hjelp fra tysk side, og at det norske militæret måtte ha det nødvendige tilsynet med arbeidet. ${ }^{98}$

Ifølge Distriktskommando Nord-Norge var det neppe avgjørende at gravplassene var velstelt, og at de lå avsides til. Det ville uansett, om forholdsvis kort tid, bli vanskelig å opprettholde et tilfredsstillende vedlikehold av gravene. Sognepresten i Folda ble derfor bedt om å komme med et forslag til en samling av gravene, fortrinnsvis til ett eller to større gravfelter. Monumenter som var satt opp på gravstedene, burde kunne flyttes sammen med gravene og settes opp på det nye stedet. ${ }^{99}$ Litt senere ble det avklart at forslaget til sognepresten i Folda om flytting av spredte krigsgraver i området var godkjent av Distriktskommando Nord-Norge og 1. Norske Brigade. Forslaget tilsa at gravene i og ved Lappelv, Buvik, Megård, Gyltvik, Torkilseng, Aspfjord og Fagerbakk skulle flyttes til den norske kirkegården ved Ørvik. Gravene i og ved Storvik og Sørfjord skulle flyttes til gravplassen i Kroken, og det ble foreslått at anlegget her ble innviet til kirkegård. Ifølge forslaget skulle gravene ved Kobbvatn bli liggende og anlegget innvies til kirkegård. 1. Norske Brigade ble bedt om snarest mulig å beordre tyske befal og mannskap til å starte arbeidet med flyttingen av gravene i overensstemmelse med sogneprestens forslag. Sognepresten fikk ansvaret med å holde oppsyn med den tyske kommandoen under arbeidet med flyttingen. Monumenter og minnesmerker skulle tas med og gravene grupperes rundt vedkommende støtte, slik at de forskjellige gravplassene kunne finnes igjen som en særskilt enhet på samlekirkegården. På gravstedene hvor det var oppsatt kors, burde disse tas med og settes opp på det nye gravstedet. Ved gravene hvor det manglet kors, mente man det burde bli beordret at dette ble satt opp. ${ }^{100}$ Disse opplysningene viser at både sognepresten og militære myndigheter var svært opptatt av å unngå flytting der de anså dette for unødvendig, og at det var viktig at minnesmerker ble ivaretatt og gravene markert med kors.

Et år senere var også lensmannen i Folda opptatt av gravene ved Kobbvatn. Lensmannen var først i 1946 blitt klar over at det fantes om lag 100 sovjetiske krigsfanger som var gravlagt i Gjerdalen (Kobbvatn) på en egen kirkegård. Lokalbefolkningen fortalte at flesteparten av fangene døde av sult. Politiet i

98 RA, DKN, 316 krigsgraver i Nord-Norge. Notat, sognepresten i Folda. Røsvik i Salten 10.08.1945.

99 RA, DKN, 316 krigsgraver i Nord-Norge. "Samling av spredte krigsgraver», Folda. D.K.N. Tromsø 10.08.1945.

100 RA, DKN, 316 krigsgraver i Nord-Norge. «Ad krigsgravsteder». 1. Norske Brigade. Bodø 24.08.1945. 
Bodø hevdet at sognepresten i Folda ikke hadde hatt rede på disse gravene. Politiet antok derfor at sovjetiske myndigheter ikke visste om gravene, og at det muligens var grunn til å kontakte ambassaden i Oslo. ${ }^{101}$ På bakgrunn av sogneprestens omfattende arbeid med gravene i Kobbvatn i 1945 virker det litt merkelig at politiet i Bodø ikke var klar over gravene her. En forklaring på dette kan være at politiet ikke var informert om arbeidet med flyttingen av gravene i 1945 .

Et par år senere kontaktet Distriktskommando Nord-Norge lensmannen i Sørfold angående krigsgravene i området. De oppga en liste over 14 steder hvor det i hovedsak var gravlagt sovjetiske ofre, men listen inneholdt også informasjon om åtte polske fanger som var gravlagt ved Lappelv og en tysker som var gravlagt på Røsvik kirkegård. Sommeren 1945 ble det jobbet med en samling av disse gravene. Tyskere skulle utføre arbeidet, og norske militære skulle føre tilsyn og bidra til arbeidet med gravene. Til tross for at det ble utarbeidet detaljerte planer for dette arbeidet, ble det aldri laget noen oversikt over hva slags arbeid som faktisk ble gjennomført. Ifølge den opprinnelige planen skulle gravene bli samlet på de fire stedene Kobbvatn (100 sovjetiske), Kroken (560 sovjetiske), Ørvik kirkegård på Helland (143 sovjetiske og åtte polske) og Røsvik kirkegård i Nordfold (ukjent antall). ${ }^{102}$

Funnene ved oppgravingene i dette området viser et forholdsvis stort sprik i antallet som ble funnet og antallet som var registrert gravlagt. Årsaken til dette kan være at det var kaotiske forhold ved registreringen av sovjetiske krigsgraver kort tid etter frigjøringen. Den tyske gravekommandoen fikk neppe instrukser om å føre detaljert oversikt over ofrene, og det finnes ingen informasjon som tyder på at lokale militære myndigheter har ført nøye oversikter. Dermed ble det rapportene fra sogneprestene som ga de mest detaljerte opplysningene om de sovjetiske ofrene.

Distriktskommando Nord-Norge samarbeidet med allierte militære myndigheter for å samle gravene. Øverstkommanderende for Tromsø zone, major Daa, ga instrukser for arbeidet med gravene i de ulike områdene. Områdene var delt in i zone $\mathrm{A}, \mathrm{B}$ og $\mathrm{C}$. Han påpekte at det var for det meste sovjetiske graver i området, og i alle tilfeller der flytting av gravene var nødvendig, hadde sovjetiske diplomater gitt klarsignal til at disse kunne flyttes til spesielle gravplasser. Kommandantene i de ulike områdene fikk ansvaret for å samle inn all informasjon om antallet gravlagte, identifikasjonen av de døde og lokaliseringen av eventuelle nye graver. Alle disse opplysningene skulle

101 RA, RAFA-2018/D/Da/L0023. «Russiske graver i Folla?» Bodø politikammer. Bodø 10.10.1946.

102 RA, DKN, 316 krigsgraver i Nord-Norge. «Ang. krigsgraver i Sørfold». Røsvik i Salten 09.04.1947. 
sendes til sovjetiske myndigheter. I de tilfellene der det var mistanke om krigsforbrytelser, ble ofrene ikke gravd opp, men detaljer omkring lokalisering ble registrert. Arbeidet vedrørende disse gravene fikk egne instruksjoner av Civil affairs. Major Daa påpekte at de detaljerte undersøkelsene angående gravene, som skulle sendes til sovjetiske myndigheter, omfattet kun de sovjetiske ofrene og ikke andre nasjonaliteter. ${ }^{103}$

Den britiske avdelingen «38 Graves Registration Unit» deltok også i planleggingen og gjennomføringen av arbeidet med registrering og samling av krigsgraver. Denne enheten bestod av britisk militært personell som deltok i arbeidet med å kartlegge tyske krigsforbrytelser i Norge. Britene fikk ansvaret for oppgraving og samling av alle døde langs kysten og på øyene fra Leka på Helgeland til Kirkenes i Finnmark. Ifølge planene skulle de døde samles i sentrale kirkegårder i Narvik, Ballangen eller Tromsø. Foreløpige tall viste at dette omfattet om lag 90 døde, men britene antok at dette tallet kunne bli mye høyere når undersøkelsene startet. Etter britenes forslag skulle tyske krigsfanger brukes til arbeidet med oppgravingen. De ønsket også at lensmenn eller andre lokale myndigheter skulle få ansvaret for å betale for innkvartering av den tyske arbeidshjelpen og transporten av de døde, siden dette hadde skapt problemer

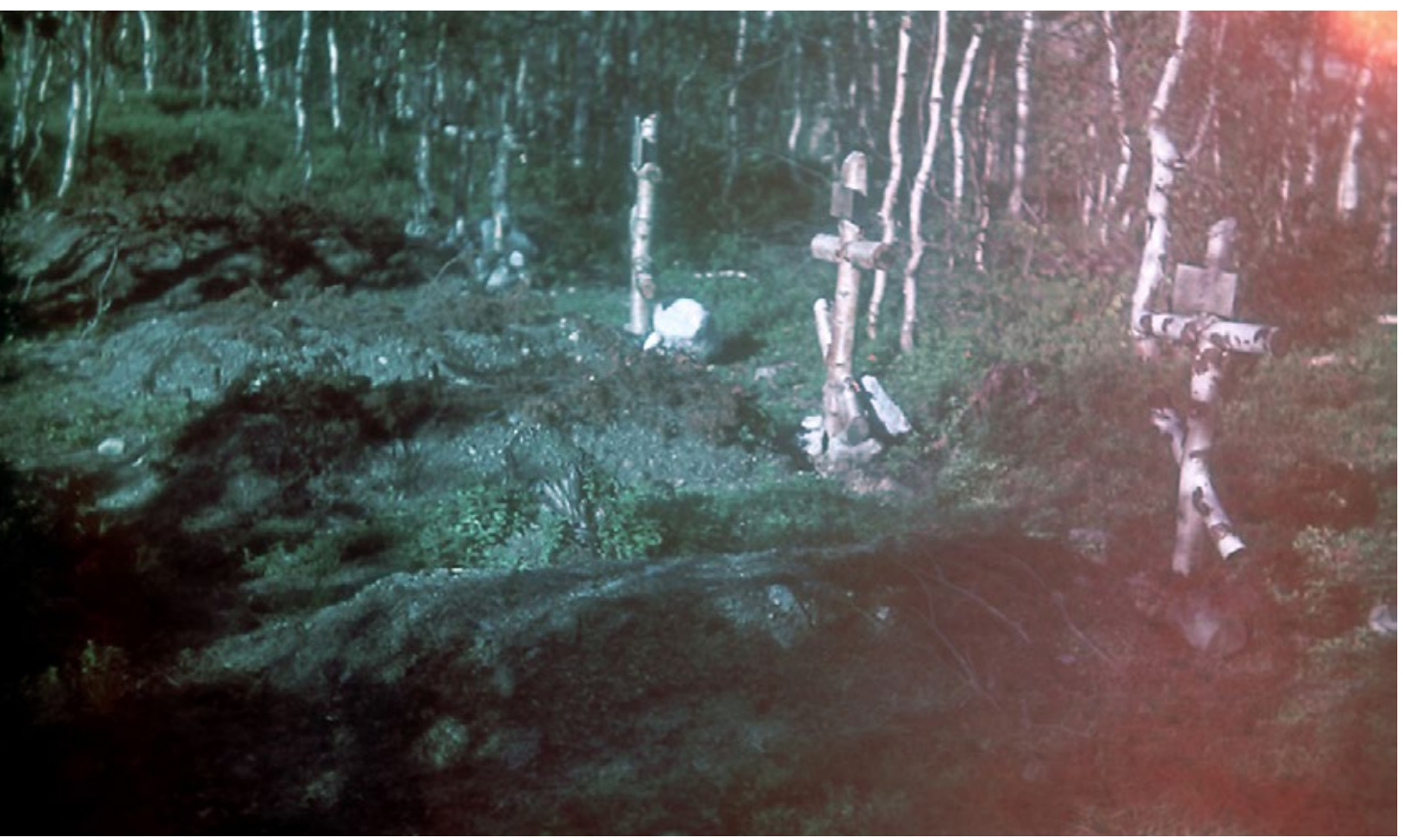

Graver i Mørsry 1944. Fotograf Johannes Martin Hennig. Foto: Nordlandsmuseets billedsamling.

103 RA, DKN, 316 krigsgraver i Nord-Norge. «War graves». HQ Tromsø zone. 12.07.1945. Ordet zone ble brukt på grunn av at det var det britiske militæret som hadde ansvaret for dette arbeidet. 
for dem ved tidligere oppdrag. Hærens overkommando fikk ansvaret for å instruere Distriktskommando Nord-Norge om å bistå den britiske enheten i dens arbeid. ${ }^{104}$

Distriktskommando Nord-Norge utarbeidet en rapport om gravlegging av døde krigsfanger i den sørlige delen av Nordland. Rapporten avdekket at det fra Ballangen sør for Narvik til Polarsirkelen på Saltfjellet var gravlagt om lag 2500 krigsfanger fordelt på 40 gravsteder. I tilknytning til arbeidet med rapporten hadde ulike tyske enheter innrømmet at dokumenter om døde sovjetiske krigsfanger ble brent sammen med andre dokumenter umiddelbart etter kapitulasjonsdagen. De ble derfor nødt til å bruke opplysninger hentet fra lokalbefolkningen eller personer i hjemmestyrkene. Store avstander og vanskelige transportforhold, særlig for området Kroken-Megården, krevde mer tid til undersøkelser. I rapporten ble det fremhevet at helhetsinntrykket ble så mye mer forstemmende fordi gravstedene i de fleste tilfellene lå pietetsløst og vilkårlig til i terrenget. I dagene etter den tyske kapitulasjonen hadde de overlevende krigsfangene utført et prisverdig arbeid for å ta vare på gravstedene. De fleste gravstedene var inngjerdet og hadde en felles gravstøtte. Enkeltgravene var markert med kors med navn på den avdøde. Men en nærmere undersøkelse viste at materialene og knapp tid hindret krigsfangene i å gi vedlikeholdet av gravene noen varig verdi. På enkelte graver var korsene allerede falt ned og mange av fellesstøttene var fundamentert for dårlig. Man antok at disse forholdene i tillegg til beliggenheten ville føre til at gravstedene ble bortgjemt og glemt. ${ }^{105}$

Målet var å samle gravene innenfor ulike områder i Nordland. I området Ballangen-Mørsry ønsket man å samle 616 døde sovjetiske krigsfanger på to kirkegårder i Engeløya og Vatsmo. Samtlige gravsteder som ble anbefalt flyttet til Vatsmo, lå nær riksvei 50. I området Kroken-Megården var 734 sovjetiske krigsfanger gravlagt, og det ble foreslått å samle disse på kirkegårder i Kroken, Øyrvik og Aspfjord.

104 RA, DKN, 316 krigsgraver i Nord-Norge. «Assistanse til Graves Registration Officers fra 38 Graves Registration Unit (38 G.R.U)». Hærens Overkommando. Oslo 25.06.1946.

105 RA, DKN, 316 krigsgraver i Nord-Norge. «Rapport avgitt av Carsten Larsen». Rognan 20.07.1945. 
I Fauske-området var det gravlagt 63 sovjetiske krigsfanger. 50 av disse var gravlagt på Fauske kirkegård, og ifølge rapporten ønsket man å flytte 13 graver fra Hjemås til Fauske kirkegård. I området Stamnes-Bjørnelva var det registrert 1202 sovjetiske ofre. Forslaget gikk ut på å flytte disse til kirkegårdene Botn og Hestbrinken. Det var allerede utarbeidet en tegning for Hestbrinken kirkegård. Gravene der navnene var kjent, skulle merkes, og det var planlagt et større felles monument på kirkegården. Arbeidet med opparbeidelsen av kirkegården var kommet godt i gang. Arbeidet ble utført av en tysk arbeidskommando under ledelse av en oppsynsmann fra jernbanen, og overføringen av ofrene kunne starte etter kort tid. Til slutt i rapporten fra Distriktskommando Nord-Norge ble det inntatt en kommentar til dødsårsaken blant de sovjetiske krigsfangene. I de fleste tilfellene hadde fangene dødd av sult, men man mente at mange var planmessig drept på mange andre måter. Mange ofre var registrert av tyskerne som skutt under flukt. Vitner kunne også i flere tilfeller fortelle om hendelser de beskrev som rene lystmord. Noen få av de tyske krigsforbryterne som var skyldig i drapene, ble arrestert av hjemmestyrkene, men de fleste greide å skjule seg, godt hjulpet av den tyske ledelsen. ${ }^{106}$

I samråd med biskopen i Hålogaland sendte Distriktskommando NordNorge en kunngjøring i forbindelse med samlingen av spredte krigsgraver i 1945. Det ble påpekt at dette kommandodistriktet hadde mange spredte graver, hvor det særlig befant seg henrettede sovjetiske ofre. Både av pietetshensyn og andre årsaker var det ønskelig at disse gravene ble flyttet til nærmeste kirkegård snarest. Enkelte steder ble det av plasshensyn nødvendig å innvie nye kirkegårder. Alt arbeid med oppgraving, anskaffelser av kister, transport og ny gravlegging skulle utføres av tyske avdelinger. Jordfestelse ville bli utført av norske prester. I denne anledning ble det anmodet om at enhver som visste at det på deres eiendom lå spredte graver, snarest mulig måtte melde ifra om dette til sognepresten med opplysninger om gravplassenes antall, beliggenhet og tilstand. Steder der det var mistanke om krigsforbrytelse, måtte rapporteres, i tillegg til andre opplysninger som kunne ha betydning for identifikasjonen av ofrene. I samarbeid med biskopen skulle det bli sørget for at de allierte Sub Zone Commanders mottok alle opplysningene om gravene slik at de kunne gi nødvendige ordrer til de tyske avdelingene i området. Sjefen for Distriktskommando Nord-Norge, oberst Munthe-Kaas, påpekte i denne forbindelse at man måtte handle raskt for å kunne benytte den tilgjengelige tyske arbeidshjelpen før tyskerne ble ført ut av landet. Biskopen fremhevet også dette poenget, og at den enkelte kommune, om dette ble gjort på et senere tidspunkt,

106 RA, DKN, 316 krigsgraver i Nord-Norge. «Rapport avgitt av Carsten Larsen». Rognan 20.07.1945. 
ville få omkostningene ved det som måtte gjøres. ${ }^{107}$ Sommeren 1947 opplyste Sentralkontoret for krigsgraver at 166 sogneprester hadde levert rapport om utenlandske statsborgere som var begravet i Norge under okkupasjonen. For kontrollens skyld ba Sentralkontoret også de øvrige sogneprestene om å sende inn rapporter selv om det ikke fantes slike krigsgraver i deres prestegjeld. På grunn av at listene over tyske krigsgraver var upålitelige, ba Sentralkontoret om at sogneprestene også samlet inn opplysninger om antallet tyske graver på steder med færre enn 15 graver. ${ }^{108}$ Det var åpenbart vanskelig å skaffe oversikt over antallet spredte graver og gravsteder hvor det var få utenlandske ofre. Foreløpig skulle det ikke foretas en samling av spredte graver hvor dette ikke var ansett som nødvendig. Unntaket var de stedene der gravene måtte flyttes av helsemessige grunner. ${ }^{109}$

Det var ikke alltid like enkelt å få samlet gravene. Sognepresten i Lyngen hadde ansvaret for tilsynet med samlingen av spredte krigsgraver i dette prestegjeldet. Han foreslo at alle lik som ble funnet i området, skulle overføres til Hatteng kirkegård. Dette lot seg ikke gjennomføre da en engelsk major i Skibotn var uvillig til å ordne dette for alle som ble funnet. Britiske militære myndigheter, ved War Crimes Investigation Branch, hadde ansvaret for alle militære spørsmål i området. Sognepresten fremhevet likevel at kirkegårdene for de sovjetiske ofrene var godt stelt og inngjerdet i Lyngen. ${ }^{110}$

I bladet Tromsø ble det kunngjort at funn av sovjetiske lik skulle meldes til sognepresten i Lyngen. Kunngjøringen ga resultater, og det ble rapportert om flere funn i Skibotn-området. På Bensjord i Skibotn var det funnet noen graver i nærheten av bebyggelsen, og folk ba om at disse ble fjernet. To personer fra Skibotn som hadde vært på reinvakttjeneste ved grensen til Finland, hadde funnet en plass hvor de antok at det kunne være mellom ti og 20 lik. Stedet lå ved Galgovatn i Skibotndalen, og en del av likene lå synlig til i terrenget. De to hadde også hørt av den samiske befolkningen i området at de hadde funnet lik et par andre steder i samme område, som også lå synlig til. De frigitte sovjetiske krigsfangene var reist fra området, men de hadde fortalt at det skulle ligge mange lik begravd i fyllingen til en vei som tyskerne hadde bygd over Falsnesåsen ved Skibotn. ${ }^{111}$

107 RA, DKN, 316 krigsgraver i Nord-Norge. «Rundskriv nr. 4 1945». Fra Hålogalands biskop til prestene i bispedømmet. Tromsø 02.08.1945. Sub Zone Commanders var kommandanter i ulike underavdelinger som tilhørte de allierte militære myndighetene i Nord-Norge.

108 RA, RAFA-2018/D/Da/L0024. "Tilleggs rundskriv fra Sentralkontoret for krigsgraver». Sentralkontoret for krigsgraver, Hærens Overkommando. Oslo 10.06.1947.

109 RA, Krigsgravtjenesten, eske 26-35. «Krigsgraver i Norge». 18.08.1947.

110 RA, DKN, 316 krigsgraver i Nord-Norge. Sognepresten i Lyngen. "Ad samling av spredte krigsgraver i Lyngen». Lyngseidet 11.09.1945.

111 RA, DKN, 316 krigsgraver i Nord-Norge. «Brev til sognepresten i Lyngen». Skibotn 26.07.1945. 
Allierte myndigheter, ved britiske militære, mottok en oversikt fra sognepresten som viste elleve steder i Lyngen der sovjetiske ofre var synlige i terrenget. Ifølge planen ville britene beordre tyske mannskaper til å flytte alle gravene som var funnet til kirkegården på Hatteng. Sognepresten hadde ansvaret for instruksene vedrørende flyttingen. Britenes plan var å skaffe nye kors til de gravene som var funnet. Man antok at det ville bli funnet minnesmerker som var laget av medfanger ved de ulike gravstedene. Etter planen skulle disse flyttes sammen med gravene og plasseres på kirkegården nær gravene fra de ulike funnstedene. ${ }^{112}$

Den sovjetiske ambassaden var opptatt av samlingen av de sovjetiske krigsgravene i Nord-Norge. Assisterende militærattaché oberstløytnant Prokhorow ankom Harstad 3. september 1948 for å drøfte spørsmålene om tilsyn med og vedlikehold av sovjetiske krigsgraver. Spørsmålet om å samle spredte graver i et overkommelig antall større krigskirkegårder eller overføring til allerede eksisterende kirkegårder ble også drøftet. Detaljerte forslag ble ikke diskutert, men Forsvaret sa seg villig til å bidra til en gjennomføring av en tilfredsstillende ordning. Prokhorow påpekte at den sovjetiske ambassaden var interessert i å få så nøyaktige rapporter som mulig over antallet sovjetiske krigsgraver. Fra norsk side ble det foreslått å sende dette fra Sentralkontoret for krigsgraver via Utenriksdepartementet. Forsvaret opplyste at de skulle komme tilbake til spørsmålet om samling av gravene. De fremhevet at det burde tas hensyn til at krigsgraver for fremmede makters falne ikke burde ligge i militært viktige områder. ${ }^{113}$ Militære hensyn skulle også vise seg å bli sentralt i Sør-Norge.

\subsection{Sør-Norge}

I Sør-Norge var den første samlingen av gravene særlig knyttet til ofrenes rett til et verdig gravsted, vedlikeholdet av gravene, arbeidet med identifikasjonen av ofrene, det tyske sikkerhetspolitiets krigsforbrytelser og delvis spørsmålet omkring gravsteder i militære områder.

Tyskerne viste liten forståelse for de sovjetiske ofrene og deres rett til et verdig gravsted. På Vigra i Ålesund mistet fire sovjetiske krigsfanger livet. I avhør året etter krigsslutt fortalte en nordmann som hadde jobbet for tyskerne, at de sovjetiske krigsfangene på Vigra ble forgiftet av kullos og døde. ${ }^{114}$ Den tyske overløytnanten Meneche ga ordre om at de døde skulle gravlegges utenfor

112 RA, DKN, 316 krigsgraver i Nord-Norge. HQ, Sub Zone C. «Concentration of war graves». Lyngen. Tromsø 20.08.1945.

113 RA, Krigsgravtjenesten, eske 26-35. «Russiske krigsgraver». Distriktskommando NordNorge. Harstad 24.09.1948.

114 RA, RAFA-2018/D/Da/L0023. Rapport. Lensmannen i Haram 18.03.1946. 
kirkegårdsmuren og ikke i innviet jord på kirkegården fordi de var hedninger. Medfangene satte opp kors på gravene og skrev navnene på de døde med vannmaling. Navnene forsvant fort på grunn av regnværet. Etter dette ble navnene risset inn i korsene med kniv. I etterkant av krigen forsøkte lensmannen etter beste evne å tyde navnene på gravkorsene da Ålesund politikammer samlet opplysninger om døde sovjetiske krigsfanger i distriktet. Lensmannen fremhevet at sivilbefolkningen på Vigra hadde hatt stor medfølelse med de sovjetiske krigsfangene i tysk fangenskap i dette området. ${ }^{15}$

I samme distrikt ble to sovjetiske krigsfanger fra leiren på Kobbevik gravlagt på kirkegården på Åram i Sande i 1942. Den norske kirketjeneren fortalte at tyskerne gravla de døde på kirkegården om natten, og at han ble nektet å være til stede under gravleggingen. Etter frigjøringen kom fire frigitte sovjetiske krigsfanger for å stelle den ene graven. En av dem hadde kommet til Kobbevik sammen med de to som var gravlagt og vært der frem til frigjøringen. Kirketjeneren spurte hva de to krigsfangene døde av og fikk til svar at den ene døde av sykdom og den andre ble slått i hjel. Fangene hadde hatt i oppdrag å bære sementsekker, og den ene fangen var svak og greide ikke det tunge arbeidet. Den tyske underoffiseren Ritzel slo ham derfor så lenge med en kjepp over ryggen at han datt sammen og ble liggende. Kameratene til fangen bar ham tilbake til fangeleiren. Et par dager senere døde han av mishandlingen. Kirketjeneren var usikker på om noen nordmenn hadde vært vitne til denne mishandlingen, men Ritzel var kjent for sin brutale behandling av de sovjetiske krigsfangene og hadde tilnavnet «redsel». Det viste seg at noen nordmenn hadde sett mishandlingen, og en mann fortalte at Ritzel hadde dratt fangen ut av køya to dager etter mishandlingen og sparket ham. Et annet vitne fortalte at Ritzel kunne finne på å banke de sovjetiske krigsfangene helt uten grunn. Men Ritzel ble særlig rasende i de tilfellene der han oppdaget at fangene tok med seg potetskrell eller torskehoder og stakk dette under jakkene. Vitnene så at han banket fangene med geværkolben eller et jernspett i flere slike tilfeller. ${ }^{116}$ Nordmennene var vitne til mishandlingen av krigsfangene, men det var ingenting de kunne gjøre for å stoppe dette.

Det kan se ut som om behovet for vedlikehold har gått foran mulighetene til å synliggjøre de sovjetiske ofrenes navn. I 1947 gjennomførte menighetsrådet i Norderhov i Buskerud et planeringsarbeid på Haug kirkegård for å gjøre gravfeltet pent og ryddig. 16 sovjetiske krigsfanger som døde av sykdom i leiren på Eggemoen, ble flyttet til kirkegården i 1945. Kistene ble ved overføringen nedsatt $\mathrm{i}$ en fellesgrav. Etter planen skulle gravfeltet markeres med fire enkle steiner. Trekorsene med navn og fangenummer som stod på

115 RA, RAFA-2018/D/Da/L0023. Rapport Haram lensmannskontor 10.11.1945.

116 RA, RAFA-2018/D/Da/L0023. Rapport. Herøy lensmannskontor. Gurskøy 21.11.1945. 
hver grav på Eggemoen, var tatt vare på, men man var i tvil om hvorvidt disse skulle plasseres på gravfeltet igjen når planeringsarbeidet var ferdig. En forklaring på usikkerheten kan være at trekorsene var i en dårlig forfatning og at man derfor ikke ønsket å sette de tilbake på gravfeltet. Sognepresten ba derfor Sentralkontoret for krigsgraver gi ham råd om dette. ${ }^{117}$ Det forekommer ingen dokumenter som viser hva Sentralkontoret svarte, men med tanke på de problemene Sentralkontoret hadde med å identifisere sovjetiske krigsfanger som døde i Norge, er det åpenbart at trekorsene var viktige i dette arbeidet.

Den sovjetiske krigsfangen Vasilij Koslow døde i fangeleiren på Å skole i Lyngdal i Vest-Agder og ble først gravlagt 20. mai 1943 like ved skolen. Samme dag ble liket av Koslow gravd opp igjen og flyttet til kirkegården. Sognepresten i Lyngdal oppga etter krigen at det ikke var kjent når Koslow døde, og at graven hans ble jordfestet den 22. mai 1943. Det var svært uvanlig at graven til en sovjetisk krigsfange ble jordfestet under krigen. Antakelig ble dette iblant utført av norske prester, men det gis ingen opplysninger om dette. Høsten 1942 gravla tyskerne en rekke sovjetiske krigsfanger like utenfor kirkegården på Austad i Lyngdal. I en grav lå det to krigsfanger og to trekors ble plassert på graven. På det ene korset var det skrevet Stalag II B. 104839 og på det andre Stalag II B. 106253. Kort tid etter ble det gravlagt flere krigsfanger ved siden av de to, men det var uvisst hvor mange dette var, siden tyskerne ikke ga noen opplysninger om de døde og gravene deres ikke ble merket med navn eller fangenummer. I 1945 ble kirkegården utvidet slik at alle disse gravene havnet innenfor kirkegårdsmurene.

Høsten 1942 rømte en sovjetisk krigsfange fra fangeleiren på Vemestad i Kvås i Vest-Agder. Han ble raskt tatt igjen og skutt av tyskerne. Fangen ble gravlagt i skogen ved Moi. Tyskerne satte opp et trekors på graven med innskriften: Pawel Botscharow, Stalag 315 No. 26867. Etter krigen ble den døde gravd opp av russere, sannsynligvis medfanger fra leiren. De gravde graven dypere og la den døde i en kiste. På graven ble det satt opp en minnestein med innskrift på russisk. Noen meter unna var det en annen grav med seks sovjetiske ofre. På minnesteinen stod det skrevet: «6 russiske krigsfanger döde i fasistisk fangenskap 22. april 1943. Har litt av sult og kulde, derefter myrdet». Medfanger av de døde ordnet minnesteinen etter krigens slutt. Folk i Kvås mintes at tyskerne kom med likene i en lastebil skjærtorsdag 22. april 1943, og det passet også med innskriften på minnesteinen. ${ }^{118}$ Alle gravene i dette området ble senere flyttet til Lyngdal

117 RA, RAFA-2018/D/Da/L0024. «Oppgave fra Norderhov sokneprestembede». Norderhov 09.02.1947.

118 RA, RAFA-2018/D/Da/L0024. Rapport. Lyngdal sogneprestembede. 25.08.1945. 
I avhør den 20. september 1945 fortalte Friedrich Wilhelm Meyer, som tjenestegjorde i sikkerhetspolitiet i Kristiansand, om hvordan han var med på å henrette sovjetiske krigsfanger på Bragdøya:

Sommeren 1944 fikk jeg 2 ganger med korte mellomrom ordre av Hauptsturmführer Kerner om aa henrette russere som paa grunn av kriminelle forhold var dømt til döden. Jeg fikk beskjed om aa hemmeligholde ordren og om aa gjennomføre den raskt. Jeg reiste saa med russerne - navnene kjenner jeg ikke - til öya. Saavidt jeg husker var Glomb, Pettersen og Weiss med. Paa öya ble russerne henrettet ved skytning. Dödsdommen ble gjort kjent for dem paa sikkerhetspolitiets dienststelle. Jeg skjöt russerne med pistolen min i bakhodet. Pettersen, Glomb og jeg maatte grave gravene, da russerne var lenket. För vi skjöt dem fjernet vi lenkene. Saa lukket vi gravene. ${ }^{121}$

Meyer ba om en mild dom fordi han ville «gjøre godt igjen det han hadde gjort», og han var villig til å påvise gravene på Bragdøya. Meyer fremhevet også til sitt forsvar at han i 1942 ble straffet med åtte ukers fengsel for «militær ulydighet» fordi han hadde søkt om avskjed fra sikkerhetspolitiet. I Kristiansand hadde han vært fengslet $\mathrm{i}$ åtte dager på Odderøya fordi han hadde frigitt fanger, opplyste han. Til sitt forsvar fremhevet Meyer i tillegg at SS-ledelsen i Norge måtte være kjent med at henrettelser av sovjetiske krigsfanger hadde vært en svært stor belastning for de tyske tjenestemennene ved sikkerhetspolitiet i Kristiansand. Han antok at han var uttatt til å utføre dette arbeidet fordi han var forflyttet til Norge som straff. De strengeste dommene ved ordrenekt ble lest opp for tjenestemennene slik at de skulle ha de strenge straffene for øye, fortalte Meyer. Forholdene ved sikkerhetspolitiet i Kristiansand var harde, og Kerner var fryktet av sine underordnede. «Det ble bestandig sagt oss at vi skulle betrakte oss som soldater og at vi stod under krigsretten. Med slike saker ble vi stadig gjort små», sa Meyer. ${ }^{122}$

Høsten 1945 ble de to tyske krigsforbryterne Paul Glomb og Friedrich W. Meyer tatt med til Bragdøya for å påvise stedene der de hadde henrettet og begravd sovjetiske krigsfanger. Glomb fortalte at han hadde vært ute på øya med 16 krigsfanger. Alle var blitt skutt av ham, og de ble lagt i tre graver. Han hadde også vært på Bragdøya sammen med Meyer to ganger. På disse turene hadde Meyer skutt fire eller fem krigsfanger, som ble gravlagt i to andre graver. Glomb påviste stedene for de tre gravene, og norsk politi gravde et stykke ned i den største graven og konstaterte at det var flere ofre der. Det ble funnet

121 SAK, F 5. «Russersaka. Meyer dok 5». Forklaring fra oberscharführer Meyer avgitt den 20.09.1945. Akershus festning.

122 SAK, F 13, «forklaring Friedrich Wilhelm Meyer». Kristiansand S, 12.12.1946. 
elleve døde fanger. Dagen etter ble fem tyske krigsfanger satt til å grave opp alle ofrene i de tre påviste gravene. Alle ofrene var navngitte. ${ }^{123}$

Glomb tjenestegjorde ved SS i Kristiansand. Han var ansvarlig for mange henrettelser av sovjetiske krigsfanger. Ved et tilfelle ble tre sovjetiske krigsfanger kjørt ut fra Kristiansand i en båt og henrettet ved hengning i masten på båten. Ofrene ble tatt ned etter en halvtime og deretter senket i forden ved hjelp av murstein og ståltråd. Glomb og de andre tjenestemennene festet mursteinene til likene og senket dem i sjøen samtidig. Glomb opplyste at han hadde forsøkt å nekte å utføre ordren, fordi han allerede hadde blitt straffet med en klage etter at en nordmann hadde rømt da han skulle arresteres. I 1945 kunne han ikke påvise hvor ofrene ble senket i fjorden, men mente at dette måtte båtføreren vite. Glomb hevdet i avhør at ingen av tjenestemennene ved sikkerhetspolitiet i Kristiansand hadde vegret seg for å delta i henrettelser av sovjetiske krigsfanger. Alle etterkom ordrene som ble gitt av lederen Rudolf Kerner. «Vi måtte føye oss under trykket, de gitte forordninger og ordrer», påpekte Glomb. ${ }^{124}$

Politiet i Kristiansand mente at Meyer på ingen måte var like villig og nøyaktig som Glomb i sin forklaring eller i påvisningen av de forskjellige tilfellene av graver. Meyer var svært usikker i å påvise stedene og de fikk inntrykk av at han ikke snakket sant. De norske politimennene måtte peke ut stedene for Meyer, og da innrømmet han at det kunne være riktig. De mente at det ikke var tvil om at Meyer forsøkte å skjule flere henrettede sovjetiske krigsfanger. De mente Meyer var redd for at det skulle komme opp for mange tilfeller av henrettelser, siden straffen ville bli større for ham jo flere tilfeller som ble avdekket. Glomb hadde også fortalt politiet at han trodde at Meyer hadde mer på samvittigheten. Meyer skulle i tillegg ha sagt til Glomb at det ble verre for dem hvis det kom opp flere tilfeller. Politiet hadde inntrykk av at Glomb la alle kortene på bordet og prøvde å hjelpe dem med oppklaringen av henrettelsene på alle måter. For Glomb var det også formildende at han hadde hjulpet nordmenn under krigen. ${ }^{125}$

Glomb ble likevel dømt til døden av Agder lagmannsrett den 14. juni 1947. I begrunnelsen for dommen ble det lagt vekt på hans handlingers brutale og grusomme karakter. Særlig skjerpende var hengningen av de tre krigsfangene på båten og henrettelsen av elleve sovjetiske krigsfanger. De sistnevnte ble tvunget til å grave sin egen grav, kle seg nakne og knele ved gravkanten hvor de ble skutt ved nakkeskudd. De to siste fangene som ble skutt, måtte gravlegge de tidligere henrettede. Kynismen gikk så langt som at Glomb og hans hjelpere tok seg røykepauser under henrettelsene. Rettens oppfatning var

123 SAK, F 8, «rapport Bragdøya». Kristiansand S 18.10.1945.

124 SAK, F 10, Kristiansand politikammer, «avhør og forklaring Paul Glomb». Udatert.

125 SAK, F 11, rapport. Alf O. Andersen 25.10.45. «Russere der er skutt og begravd på Bragdøya». Kristiansand. 
at Glombs deltakelse i både henrettelsene og i torturtilfellene hadde vært av en særlig ondartet natur. Retten viste likevel til at Glomb hadde hjulpet enkelte nordmenn som stod i fare for å bli henrettet av tyskerne, men dette fikk ikke noen avgjørende betydning i saken mot ham. Han ble kjent skyldig i totalt 30 drap og 15 mishandlinger. Ifølge retten hadde Glombs forbrytelser vært svært graverende, og de kunne ikke se at det forelå formildende omstendigheter i saken. ${ }^{126}$

Dødsdommen til Glomb ble delvis opphevet av Høyesterett den 5. november 1949, og dommen ble omgjort til 20 års fengsel. Han ble til slutt benådet i 1950. Meyer ble dømt til døden av Agder lagmannsrett, men også denne dommen ble omgjort av Høyesterett. Han ble dømt til livsvarig fengsel i 1949. Han ble senere erklært sinnssyk og utvist fra Norge i 1952. ${ }^{127}$

En norsk fengselsbetjent ble avhørt i forbindelse med «Russersaka» i Kristiansand. Han hadde vært ansatt som fengselsbetjent i Kristiansand Kretsfengsel under hele okkupasjonstiden og antok at ca. 40-50 sovjetiske krigsfanger hadde vært fengslet i disse årene. Krigsfangene kunne bli sittende i kretsfengselet fra noen dager og opp til et par måneder. Enkelte av fangene var mistenkt for å ha dannet en kommunistisk organisasjon og planlagt flukt. Fengselsbetjenten fortalte at han så at flere av fangene hadde vært utsatt for tortur når de kom tilbake fra avhør av det tyske sikkerhetspolitiet. Fangene kledde av seg og viste ham skadene. Flere var slått og sparket i skrittet, og de hadde sterke smerter etter den brutale behandlingen. Det gikk aldri frem av fangenes forklaringer at de noensinne hadde vært stilt for eller skulle bli stilt for en domstol. Rett som det var hendte det at norske fanger fikk beskjed om at de skulle for krigsrett, men det hendte aldri at betjentene i fengselet fikk ordrer om dette når det gjaldt russerne. Når russerne forlot fengselet for godt, fikk betjentene som regel beskjed om at fangene skulle til «Arkivet» for deretter å bli sendt tilbake til fangeleiren. ${ }^{128}$ Fangene som endte opp i sikkerhetspolitiets varetekt, ble som regel henrettet og ikke sendt tilbake til leiren.

Det tyske sikkerhetspolitiets sjef i Kristiansand, Rudolf Kerner, opplyste at de fikk tilsendt Wehrmachts ordrer om behandling av sovjetiske krigsfanger først sommeren eller høsten 1943. Fanger som prøvde å flykte, var oppsetsige eller hadde begått tyveri i eller utenfor leiren, skulle henrettes. I et avhør i oktober 1945 hevdet Kerner at han hadde protestert mot Wehrmachts ordrer til sikkerhetspolitiet om å henrette sovjetiske krigsfanger. Han viste til at sikkerhetspolitiet ikke hadde en fast eksekusjonspelotong, og etter hans

126 Norsk Retstidende 1945-1949. Agder lagmannsretts dom av 14.06.1947: 178-179.

127 Nøkleby, Berit: Krigsforbrytelser. Brudd på krigens lov i Norge 1940-45. Pax Forlag, Oslo 2004: 178.

128 SAK, F 49, «avhør av betjenter fra Kristiansand Kretsfengsel». 15.04.47. 
oppfatning var det ingen av funksjonærene ved tjenestestedet i Kristiansand som var villige til å påta seg slike oppdrag.

Kerners innvendinger hadde tydeligvis ikke hatt noen påvirkning på ordrene som ble gitt, og flere tilfeller av henrettelser av krigsfanger ble gjennomført av sikkerhetspolitiet. I avhøret innrømmet Kerner at han kjente til seks-åtte tilfeller av henrettelser. Alle ordrer om henrettelser ble sendt skriftlig, og for hver ordre ble det gitt en melding om at den var gjennomført. Etter henrettelsene sendte sikkerhetspolitiet halvparten av identifikasjonsmerket og en del av klærne til de avdøde til Wehrmacht. Men Wehrmacht erklærte på sin side at fangene var strøket av deres lister, og at man ikke hadde interesse av å få tilsendt hverken merket eller klærne. Kerner hevdet at han hadde ikke deltatt i avhør av sovjetiske krigsfanger eller henrettelser. Han hadde ikke gitt ordrer om henrettelser, men bare latt kommandørens skriftlige ordrer bli gitt videre til saksbehandleren. Så vidt han husket, hadde Wehrmacht heller aldri stilt noen tolk til disposisjon vedrørende saker som gjaldt henrettelser av sovjetiske krigsfanger. ${ }^{129}$

Kerner forsøkte åpenbart å fraskrive seg ethvert ansvar for henrettelser av sovjetiske krigsfanger som var utført av det tyske sikkerhetspolitiet i Kristiansand. I rettssaken mot Kerner ble det påpekt at han hadde opptrådt på en måte som ikke kunne betegnes som annet enn umenneskelig. Kerner hadde gitt ordrene om henrettelser videre uten andre direktiver enn for eksempel nakkeskudd eller hengning, og uten å gjøre noe for å sikre at dette skulle skje med minst mulig lidelse for ofrene. Lagmannsretten mente at dette ga særlig grunnlag for å anklage ham, siden han som overordnet ved sikkerhetspolitiet kunne ha gjort mye for å mildne ofrenes fysiske og spesielt psykiske lidelser. ${ }^{130}$

I sakene mot Kerner, Glomb og Meyer fant Høyesterett at det ikke var bevist at henrettelsene hadde funnet sted uten dom, og derfor ble den tidligere nevnte dommen fra Agder lagmannsrett opphevet på dette punktet. «Russersaka» i Kristiansand viser hvor vanskelig det var å finne de sovjetiske ofrene når tyske krigsforbrytere gjorde alt for å skjule sine forbrytelser.

Norske politirapporter om drap på sovjetiske krigsfanger vitner om den tyske brutaliteten og forakten for menneskeliv som krigsfangene ble utsatt for. I november 1945 skrev Farsund politikammer en rapport om de sovjetiske ofrene på Marka kirkegård. De frigitte sovjetiske krigsfangene hadde fortalt at av de 128 ofrene som lå på Marka, visste de med sikkerhet at 27 var drept med ulike metoder av pinsler og straff. De gjenlevende fangene hadde vært vitne til at syv sovjetiske krigsfanger ble skutt foran øynene på dem. Ved

129 SAK, F 9, «avhør av Rudolf Kerner, Kriminalkommissar og SS Hauptsturmfürer». Akershus fengsel, Oslo 12.10.1945.

130 Norsk Retstidende 1945-1949. Agder lagmannsretts dom av 14.06.1947: 175. 
ett tilfelle ble en krigsfange skutt da han hadde spist noen rå poteter som lå på en åker. I et annet tilfelle skjøt tyskerne en krigsfange som prøvde å bytte til seg litt brød av en gammel kone. ${ }^{131}$

I Hordaland ble det gjennomført utgravinger på åtte steder hvor man antok at tyskerne hadde drept utenlandske statsborgere. Sovjetiske graver i dette distriktet var merket med kors og i flere tilfeller var navnene påført korsene med russisk tekst. Det ble antatt at dette var utført av de avdødes medfanger. Det ble funnet 139 sovjetiske ofre og 97 av disse lyktes man å identifisere med navn. I tillegg til identifikasjon ved hjelp av gravkors ble det funnet papirer i rester av klær, som oppga den avdødes identitet. Det ble også forsøkt å identifisere ofrene ved hjelp av tennene, men dette viste seg å være nytteløst fordi kun et fåtall av ofrene hadde hatt tannlegebehandling. Undersøkelsen viste at 52 av ofrene var skutt, åtte av disse ved nakkeskudd. To av ofrene var drept ved hengning, ti døde ved ulykker og for 67 av ofrene var det ikke mulig å fastsette dødsårsaken. Alle ofrene ble senere gravlagt på nærmeste kirkegård under tilstedeværelse av politiet og det militære. Etterforskningen av saken i Hordaland ble gjennomført av det allierte War Crimes Investigation Branch Team C (underlagt allierte militære myndigheter / Allied Land Forces Norway). Alle dokumenter ble sendt til den sovjetiske ambassaden med unntak av saker vedrørende sovjetiske ofre som ble funnet i Tennebekk ved Bergen, som var under etterforskning av norsk politi. ${ }^{132}$

Fjordane politikammer rapporterte i 1946 at det var tre gravsteder for sovjetiske borgere i deres politidistrikt. I Ervik i Selje var det gravlagt 21 sovjetiske døde og alle navnene var ukjent. På Fure i Askvoll var to sovjetiske krigsfanger gravlagt og navnene var ukjent. Det tredje gravstedet var Florø kirkegård, der en sovjetisk fange var gravlagt. Han døde på Florø sykehus. Den døde var oppført i kirkeboken med følgende personalia: «Konstantin Dudnik, født 14/12 1899 Dnepropetarovsk, fange nr. 8808-346, Dorfpernju Russland». Politimesteren hadde ikke klart å skaffe identiteten til de sovjetiske fangene som døde i Selje, men henviste rikspolitisjefen til War Crimes Investigation Team C i Bergen, som muligens kunne ha mer informasjon. ${ }^{133}$ Ett år senere opplyste sognepresten i Askvoll at det var gravlagt tre sovjetiske statsborgere på Fure, og ikke to, som politiet hadde oppgitt. Under ledelse av allierte myndigheter ble disse tre ofrene gravd opp og lagt i kister i slutten av august 1945. Deretter ble ofrene gravlagt på Askvoll kirkegård. Gravene ble vedlikeholdt av lokalbefolkningen, og blomster ble nedlagt 17. mai da folke-

131 RA, RAFA-2018/D/Da/L0023. «Rapport Farsund politikammer». Farsund 16.11.1945.

132 RA, RAFA-2018/D/Da/L0023. «Rapport Hordaland politimesterembete». 14.02.1946.

133 RA, RAFA-2018/D/Da/L0023. «Ad oppgaver over sovjetrussiske borgere som under okkupasjonen er omkommet i Norge. Politimesteren i Fjordane». Florø 01.02.1946. 
toget gikk innom gravene. ${ }^{134}$ Totalt sett viser dette at flesteparten av de sovjetiske ofrene i dette området var ukjente, og kun ved hjelp av kirkeboken var det mulig å skaffe identifikasjon på en av de døde. Gravene på kirkegårdene i Selje, Askvoll og Florø ble senere flyttet til Nygård kirkegård i Laksevåg i Bergen i tilknytning til samlingen av sovjetiske krigsgraver i Sør-Norge, som ble gjennomført etter «Operasjon asfalt».

Fanger som hadde forsøkt å rømme i dette området, ble drept av tyskerne. Tatjana Nikolayevna Dvortsova fortalte i et intervju om hvordan faren Nikolay Grigoryevich Dvortsov opplevde fangeoppholdet i Laksevåg i Bergen. I leiren var det flere fanger som forsøkte å rømme før leiren ble inngjerdet med piggtråd. Flere av hans kamerater ble tatt under rømningsforsøkene. De ble brutalt drept foran de andre fangene i leiren. En annen kamerat ble drept da han kom for nær gjerdet. En tysk vakt skjøt ham rett ned foran Nikolay. Han fortalte til datteren at i det øyeblikket han ble vitne til drapet, følte han at den siste forbindelsen til hans tidligere liv ble brutt. ${ }^{135}$

I Åsane i Bergen ble det etter frigjøringen funnet 27 døde sovjetiske krigsfanger gravlagt i ei myr ved en fangeleir et stykke fra Nyborg kirkegård i Åsane. Ingen av de døde kunne identifiseres, og den 14. juli 1945 ble de gravlagt på kirkegården. Oppgravingen ble ledet av politiet, og arbeidet ble utført av norske landssvikfanger. Soknerådet hadde samlet inn midler til en minnestein som etter planen skulle føres opp i løpet av sommeren. ${ }^{136}$ Minnesteinen ble reist av befolkningen med teksten: «Kyrkjelydane i Åsane reiste denne steinen til minne om 27 russiske soldatar som miste livet i tysk krigsfangenskap på norsk jord 1941-45. I striden for sams fridom». ${ }^{137}$ I dag er det mulig å identifisere fire av de døde som ble gravlagt i Åsane. Disse fire kan identifiseres ved hjelp av tyske fangekort fra sovjetiske arkiv. Kortene viser at tre av fangene ble sendt som arbeidskraft til O.T. Wiking (Organisation Todt) i Norge den 9. april 1943. En måned senere var alle tre registrert som krigsfanger ved «Arbeidskommando - Lg. Aasane». To av krigsfangene døde den 9. mai 1943 og den tredje døde dagen etter. ${ }^{138}$ Den fjerde fangen ankom leiren i Åsane i oktober 1943 og døde etter et halvt år. I fangekortet hans er det skrevet at han er gravlagt på «krigsfange kirkegården» i Åsane.

134 RA, RAFA-2018/D/Da/L0024. «Vedk. krigsgraver i Askvoll prestegjeld». Askvoll 07.01.1947.

135 Falstadsenterets arkiv, intervju med Nikolay Grigoryevich Dvortsovs datter Tatjana Nikolayevna Dvortsova. Intervju utført av Marina Panikar. 2010.

136 RA, RAFA-2018/D/Da/L0024. «Melding frå Hamre prestegjeld om gravlagde av framand nasjonalitet under krigen». Hamre sogneprestembete den 22.04.1947.

137 Syvertsen, Eugen: «Fortegnelse over sovjetiske krigskirkegårder og krigsgraver i Norge. Samt fortegnelse over navngitte sovjetiske statsborgere gravlagt i Norge under krigen 1941-1945». Kirke- og undervisningsdepartementet, Krigsgravtjenesten. Oslo, 1979.

138 www.obd-memorial.ru. (lest 02.05.2012) 


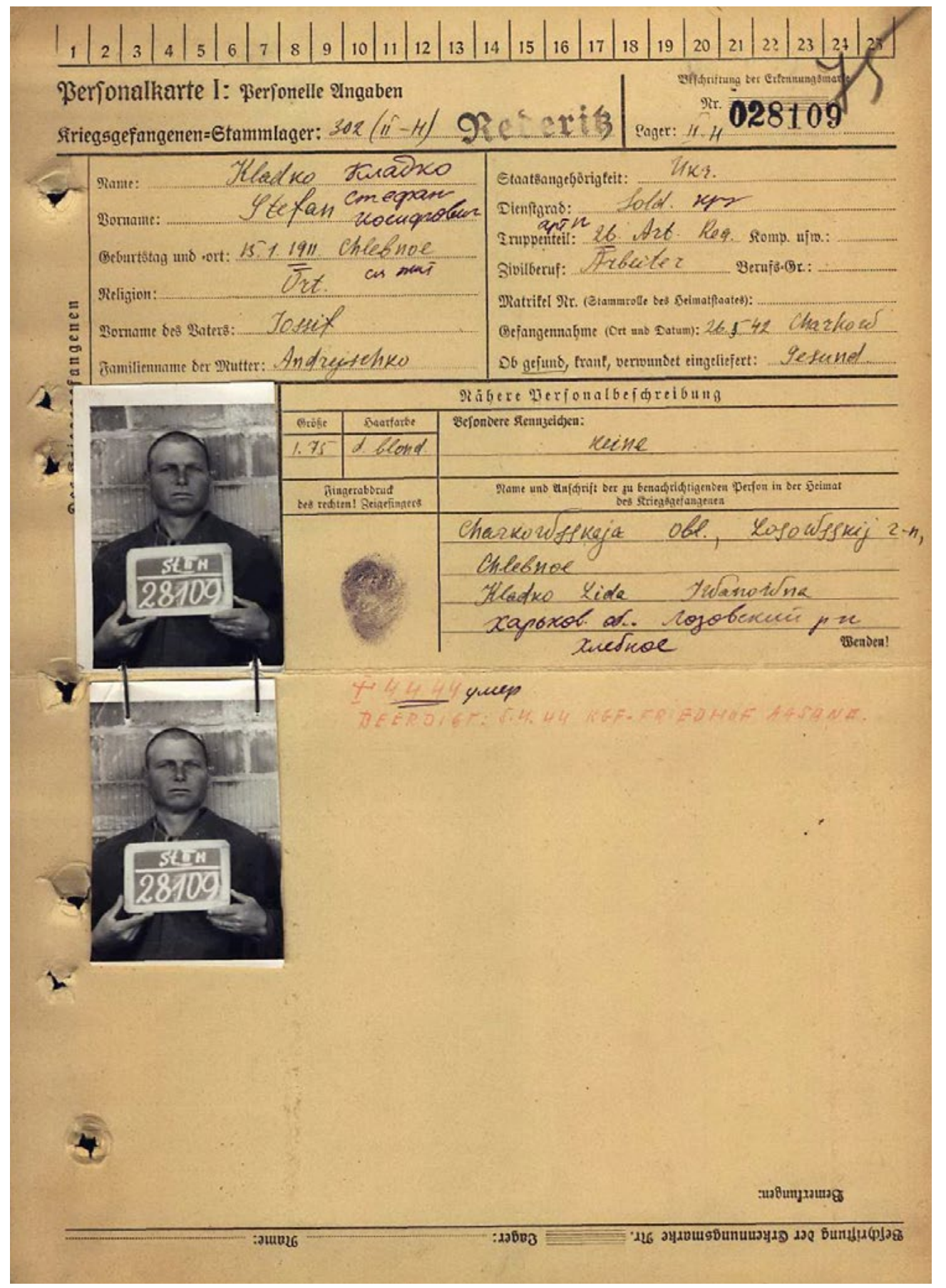

Fangekort over identifisert død fange gravlagt i Åsane. Foto: www.obd-memorial.ru. 
Sogneprestenes rapporter om utenlandske ofre på norsk jord, som ble sendt inn til Krigsgravtjenesten fra hele landet i slutten av 1940-årene, gir inntrykk av et behov for å gi de døde sovjetiske krigsfangene en verdig grav og begravelsesseremoni med prest til stede. De mange ofrene ble gravd opp fra lite tilfredsstillende og provisoriske gravplasser, som var dystre vitnesbyrd om tyske krigsforbrytelser.

Kirkevergen i Fyresdal i Telemark oppga i 1947 at tyskerne hadde gravlagt fire sovjetiske krigsfanger i skogen ved en fangeleir. I juni 1945 ble gravene åpnet, ofrene flyttet og gravene jordfestet på nye Moland kirkegård. Fire av de avdødes kamerater var til stede ved begravelsen. Bygdefolket i Fyresdal engasjerte seg i krigsfangenes skjebne, og i mai 1946 reiste de et minnesmerke på graven med navnene på de gravlagte fangene. ${ }^{139}$

Til tross for bygdefolkets engasjement er gravplassen og minnesmerket en glemt del av Fyresdals krigshistorie. Ingen i Fyresdal kan minnes at noen sovjetiske offisielle representanter har vært på kirkegården. Knut Momrak husker at de sovjetiske krigsfangene arbeidet med tømmerhogst for tyskerne. De fire fangene døde trolig av sult og tuberkulose. Medfangene gravla de døde i skogen like ved porten til Gimle skole. Bare 100 meter unna lå Moland kirkegård. "Jeg husker godt at de ble begravd like bortenfor barndomshjemmet mitt. Jeg så hvordan fangene led av sult og underernæring og hvilken glede det var da krigen var slutt og de slapp fri», forteller Knut Momrak. ${ }^{140}$ Norske nazister ble beordret til å grave opp de sovjetiske ofrene og bære dem over til kirkegården. I kirkeboken for Moland kirke står det at de fire sovjetiske krigsfangene ble gravlagt i en fellesgrav den 9. juni 1945. Siden det ikke var prest i bygda, var det soldater fra hjemmestyrkene som stod for det seremonielle. Norske motstandsfolk stod æresvakt under begravelsen av de fire russerne. Andreas Breieland og Knut Momrak stod begge æresvakt og husker godt begravelsen av de fire sovjetiske krigsfangene Ljavan Tschujitkow, Dmitrij Gorsjko, Anton Uljko og Nikita Aboloskiji. Utenfor gjerdet stod det masse folk som fulgte seremonien. Under frigjøringsdagene i 1945 var det stor interesse for hva som skjedde med de sovjetiske krigsfangene og hvilken begravelse de fikk, forteller de to. Ottar Vik, som var en av de nysgjerrige guttungene utenfor gjerdet under begravelsen, mener minnesmerket er flott og fortjener oppmerksomhet slik at denne spesielle hendelsen i Fyresdal ikke blir glemt. Den offisielle seremonien i 1946 med prest til stede er så langt den eneste og siste som har vært på gravplassen, minnes Ottar Vik. ${ }^{141}$ Det er dessverre lett å glemme slike

139 RA, RAFA-2018/D/Da/L0024. «Rapport angående utenlandske statsborgere begravet i Norge under okkupasjonen 1940-45». Fyresdal, Telemark 16.06.1947.

140 Telemarksavisa, 28.04.2006.

141 Ibid. 
gravplasser og minnesmerker hvis det ikke er etablert tradisjoner for minnemarkeringer ved offisielle myndigheter eller lokale ildsjeler.

Feltprest Guttormsen ved Krigsgravkontoret for Østlandet oppga i 1947 at det fantes 47 steder med krigsgraver i Østlands-distriktet. Fem av disse stedene var ikke innviet som kirkegård. Det var stort sett sovjetiske ofre som var gravlagt utenfor kirkegårdene. Feltpresten foreslo at kirkegårdene på Jørstadmoen og Gardermoen ble beholdt. Han viste til at major Sparr hadde satt en arbeidskommando i gang med utbedring av krigskirkegården på Jørstadmoen. På Gardermoen var det 82 sovjetiske graver og en tysk grav. Forslaget til feltpresten var at gravstedet ble beholdt som krigskirkegård, og at de sovjetiske gravene fra «vaskeri-kirkegården» (Gardermoen), Stavern, Haslemoen og Sande ble flyttet dit. Han antok at utgiftene ved gravene som skulle flyttes fra «vaskeri-kirkegården» kunne dekkes av Sosialdepartementet siden ofrene var «Ostarbeiter» (sivile sovjetiske tvangsarbeidere). Alle de øvrige gravene som lå på ordinære kirkegårder kunne bli liggende, mente feltpresten. Lokale myndigheter og menighetsforeningen hadde i stor utstrekning tatt seg av stell og vedlikehold av gravene på Østlandet uten at dette hadde medført utgifter for det offentlige. ${ }^{142}$ Mesteparten av de utenlandske krigsgravene på Østlandet lå under de kommunale myndighetenes tilsyn. Enkelte krigsgraver utenfor de ordinære kirkegårdene trengte bedre vedlikehold. Feltprestassistentene på Stavern, Trandum, Gardermoen og Terningmoen var pålagt å ha tilsyn med gravene der. I 1948 var det planlagt å flytte gravene i Stavern til Tanum kirkegård og gravene på Haslemoen til Åsnes kirkegård. På landsbasis var det på dette tidspunktet bare mulig å finne navn på 1950 av de døde. Resten hadde bare fangenummer, eller hverken navn eller fangenummer. I tillegg var det registrert en del fellesgraver med et ukjent antall døde, eller døde av ukjent nasjonalitet, som man antok kunne være sovjetiske. Hvor mange døde sovjetiske krigsfanger som kunne ligge igjen på fjellviddene eller i sjøen, var det umulig å fastslå. ${ }^{143}$

På Nordmøre og i Trøndelag var det lagt vekt på helsemessige og strategiske hensyn ved flyttingen av gravene. Utenriksdepartementet henvendte seg til Sovjetunionens ambassade i 1946 med spørsmål angående de 25-30 sovjetiske ofrene som var gravlagt på Vinjeøra i Hemne kommune på Nordmøre. Vinjeøra helseråd viste til at en vesentlig andel av disse sovjetiske ofrene døde av dysenteri, og at de var gravlagt svært grunt fra halvannen meter til nesten oppe i dagen. Nåværende gravsted var plassert i en myr, og forråtnelsesprosessen ville derfor ta lang tid. Gravplassen lå om lag ti meter fra en bekk og hele elvedraget ble brukt til drikkevann av mange i Hemne

142 RA, Krigsgravtjenesten, eske 26-35. «Krigsgraver på Østlandet». Oslo 16.06.1947.

143 RA, RAFA-2018/D/Da 31 saksarkiv. «Merknader til utskrift fra kartoteket over russergraver i Norge». 20.03.1948. 
kommune. Stedet var også en yndet rasteplass for turister, som uvitende om gravplassen hentet vann fra denne bekken. Lensmannen ga følgende uttalelse om gravene:

(...) Likene er gravlagt i myr, som regel 2 sammen innpakket i papir. Gravene ble bare löselig igjenkastet, og myrjorden er senere smuldret og mange av gravene er delvis åpne sommerstid (...) her pleier folk ofte å ta rast, særlig sommerstid og det har vært og er vanlig at de tar sitt drikkevann fra bekken (...) Det synes etter disse opplysninger å være meget önskelig at de omhandlede lik blir fjernet snarest mulig. ${ }^{144}$

Feltprest Trygve Marken i Trondheim skrev til Sentralkontoret for krigsgraver angående flytting av sovjetiske ofre. Feltpresten ønsket flytting fordi ofrene lå gravlagt i et tilsig til drikkevannet. En søknad fra Hemne kommune var innvilget slik at ofrene kunne gravlegges på den sivile kirkegården på Vinjeøra. Kommunen ville gjerne gjennomføre flyttingen så snart som mulig før det ble vanskelig å gjennomføre oppgravingen på grunn av teleløsning. ${ }^{145}$ Kontorsjefen ved distriktskontoret ga i mars 1947 sitt medhold til at gravene på Vinjeøra burde flyttes snarest mulig. ${ }^{146}$ Flytting av sovjetiske krigsgraver ble aktuelt på grunn av helsemessige forhold på et tidlig tidspunkt etter krigen, og dette var saker som hastet.

Sognepresten på Ørlandet opplyste i 1947 at 180 sovjetiske og 65 serbiske krigsfanger var gravlagt tett inntil kirkegården. Før de overlevende fangene reiste hjem sommeren 1945, reiste de en minnestøtte over sine døde kamerater. Sognepresten hadde et ønske om at gravplassen ble lagt til kirkegården og tatt vare på av myndighetene. Gravene ble senere flyttet til gravsteder i Sør-Trøndelag. Så sent som i 1953 ble det tatt opp 76 sovjetiske graver på Ørlandet, som ble overført til kirkegården på Vinjeøra. Det var Gorduskompaniet ${ }^{147}$ som hadde ansvaret for arbeidet med flyttingen av gravene på Ørlandet. Prest, kirkeverge og graver ble kontaktet for å lokalisere gravene. Det sovjetiske gravfeltet var velordnet, og flesteparten av ofrene var gravlagt i kister. ${ }^{148}$ Et sentralt spørsmål er hvorfor gravene ble flyttet så langt som til Vinjeøra fra Ørlandet, men dette ble antakelig gjort på grunn av flyplassen som var plassert ikke langt fra kirkegården på Ørlandet.

144 RA, Krigsgravtjenesten, eske 26-35. Avskrift. P.M. Oslo 07.10.1946.

145 RA, Krigsgravtjenesten, eske 26-35. «Til centralkontoret for krigsgraver». Trondheim 12.03.1947.

146 RA, Krigsgravtjenesten, eske 26-35. «Distriktskontoret for krigsgraver». 25.03.1947.

147 Gorduskompaniet var et privat firma fra Oslo med virkeområde spesialoppdrag, transport og gravning.

148 RA, Krigsgravtjenesten, eske 26-35. «Ørlandet». Oslo 1953. 
På enkelte steder virket forslaget om flytting av gravene håpløst med tanke på engasjement hos lokalbefolkningen og påkostning av minnesmerker ved gravstedene. Høsten 1949 ble Oppdal kommune gjort oppmerksom på at Forsvarsdepartementet muligens ønsket å flytte sovjetiske krigsgraver av strategiske hensyn. Krigsgravtjenestens distriktskontorer informerte derfor kommuner eller organisasjoner som arbeidet med minnesmerker. Distriktskontoret for krigsgraver i Trondheim ønsket ikke at en eventuell flytting av gravene på Oppdal skulle komme som en overraskelse på kommunen, og holdt derfor ordføreren informert om saken. ${ }^{149}$

Ordføreren i Oppdal fremhevet at saken var rystende for formannskapet i bygda. Årsaken til dette var at et anlegg med minnesmerke og gjerde nesten var ferdig, og avdukingen var planlagt den 17. mai 1950. Det var meningsløst å skulle rive hele anlegget. Anlegget var lagt i et område som ville bli godt besøkt både av bygdas folk og tilreisende. Gravplassen og minnesmerket ville bli et minne om krigsårene, og man mente det var et arbeid for trygging av freden. Dessuten hadde den sovjetiske militærattacheen i Oslo vært på stedet og uttrykt at han var meget godt fornøyd med anlegget. ${ }^{150}$

Distriktskontoret hadde forståelse for ordførerens bekymring, og sa de kunne regne med at gravene ble liggende siden arbeidet med anlegget var kommet så langt. Feltpresten ved kontoret henviste til sakens strategiske hensyn og det faktum at man fryktet for spionasje, men siden Oppdal ikke hadde militære anlegg av betydelig grad, ville dette neppe bli et avgjørende argument for flytting av gravene. Etter feltprestens oppfatning ville arbeidet med anlegget fremstå som tragikomisk om alt ble fjernet. ${ }^{151}$

Kommunikasjonen med Sentralkontoret for krigsgraver angående saken på Oppdal var ikke den beste. SentralkonMonumentet på Oppdal krigskirkegård 2010. Foto: Per-Otto Gullaksen. toret var blitt klar over avdukingen av

149 SAT, E1, Tilv. 2, Distriktskontor for krigsgraver Trondheim. Notat, Trondheim 22.10.1949.

150 SAT, E1, Tilv. 2, Distriktskontor for krigsgraver Trondheim. Notat, Oppdal 25.10.1949.

151 SAT, E1, Tilv. 2, Distriktskontor for krigsgraver Trondheim. Notat, Persaunet 02.11.1949. 
minnesmerket via dagspressen våren 1950. Kaptein Eugen Syvertsen ved Sentralkontoret ga beskjed til feltpresten i Trondheim at de ikke hadde kjennskap til avdukingen av minnesmerket på Oppdal og ba ham undersøke saken. Feltpresten viste til at dette var en sak som omsider hadde fått en løsning. Saken hadde vært langvarig og til slutt ble det enighet om avduking 17 . mai $1950 .{ }^{152}$ Sentralkontoret var heller ikke informert om at elleve sovjetiske ofre var flyttet fra Grytten kommune og til anlegget på Oppdal. Dermed var 104 sovjetiske ofre gravlagt

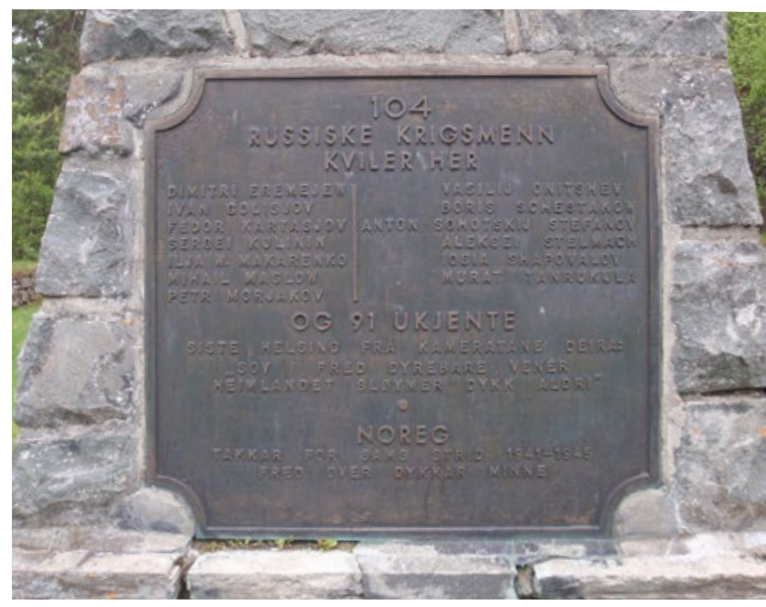

Navneliste på monumentet på Oppdal krigskirkegård 2010. Foto: Per-Otto Gullaksen. på Oppdal. I dette tilfellet var det et lokalt engasjement for de sovjetiske gravene som forhindret at de ble flyttet.

I et forsøk på å skaffe seg en oversikt over antallet krigsgraver og hvilke graver som eventuelt måtte flyttes, sendte Østoppland Infanteriregiment 5 ut en liste med flere spørsmål til alle sogneprestene angående gravene i deres distrikt. Spørsmålene var:

1. Hvor mange krigsgraver finns det i Deres distrikt? Navnlig fortegnelse önskelig.

2. Antall av de forskjellige nasjonaliteter - militære, sivile?

3. Fins det graver utafor kirkegård - innviet gravplass som må flyttes?

4. Fins det spesielle krigskirkegårder og som det blir spörsmål om å flytte?

5. Fins det graver som ikke blir skjöttet av pårörende, offentlige eller private institusjoner eller foreninger?

6. Andre ting som hr. soknepresten finner måtte være av interesse i forbinnelse med krigsgraver? ${ }^{153}$

Sognepresten i Åmot i Hedmark rapporterte at to sovjetiske krigsfanger ble skutt ved Løsset fangeleir (Rena) i løpet av krigsårene, men at den ene ikke ble funnet. Den andre ble gravlagt etter sovjetisk skikk og graven markert med trekors. Graven lå på brakkeområdet til den tidligere fangeleiren. Sovjetiske myndigheter viste ikke interesse for graven etter krigen. ${ }^{154}$ På Dovre oppga sognepresten at der var en sovjetisk krigskirkegård som ikke var innviet. Her var

152 SAT, E1, Tilv. 2, Distriktskontor for krigsgraver Trondheim. Notat, Persaunet 27.05.1950.

153 SAH, Östopland I.R.5. «Krigsgraver». Elverum 08.05.1947.

154 SAH, Östopland I.R.5. «1 russer-grav i Lösset fangeleir». Åmot 13.06.1947. 
17 sovjetiske krigsfanger gravlagt. Gravplassen lå avsides til, og sognepresten mente at det ikke var nødvendig å flytte de gravlagte. Han opplyste også at Dovre heradstyre sommeren 1945 nedsatte en nemnd til å ta seg av de allierte soldatgravene. Nemnden hadde vært i kontakt med den sovjetiske ambassaden i Oslo, og det var blitt enighet om å få satt opp kors med navn på gravene. ${ }^{155}$ Ingen av gravstedene som ble innrapportert, ble ansett for nødvendig å flytte. Andre nasjonaliteters graver som ble registrert, var i hovedsak norske sivile og militære som døde under kampene med tyskerne i 1940, eller som døde i løpet av krigsårene, samt tyske soldater som ble gravlagt i 1945 og 1946.

Feltprest Finn Guttormsen ba i september 1949 om at det ble gjort forberedelser til flytting av sovjetiske graver på Østlandet til Jørstadmoen. Det var påkrevd flytting fra Bolærne, Stavern, Sande, Haslemo, Trandum og Gardermoen. Samtlige graver var plassert utenfor kirkegård. Alle gravstedene, unntatt Sande, var plassert på eller i umiddelbar nærhet av militært område. Bakgrunnen for at Jørstadmoen ble foreslått som samlingsplass, var det høye antallet sovjetiske ofre som allerede var gravlagt der, at kirkegården var satt i stand og at den hadde et verdig utseende. I tillegg var det rimelig å leie området som var nødvendig for utvidelsen av kirkegården, og det var en enkel sak å få gjennomført utvidelsen. Guttormsen viste også til at det ikke forelå planer om å flytte kirkegården ved Jørstadmoen. ${ }^{156}$ Forslaget om flytting ble anbefalt av Eugen Syvertsen fra Sentralkontoret for krigsgraver. Gravene ble imidlertid ikke overført til Jørstadmoen, men til Vestre gravlund i Oslo.

I første omgang var Forsvarsdepartementet opptatt av å samle spredte graver til større enheter av hensyn til de fremtidige vedlikeholdsutgiftene. Departementet sendte i slutten av 1949 en fortegnelse over fremmede krigsgraver i Norge til Forsvarsstaben. Fortegnelsen inneholdt lister over alle fremmede krigsgraver som var funnet på ordinære kirkegårder, krigskirkegårder og i utmark over hele landet. De ønsket å vite om militære hensyn, som var av betydning ved bedømmelsen av hvilke gravsteder som kunne opprettholdes, og hvilke som burde flyttes. Forsvarsstaben ba derfor Hærens overkommando om å velge ut hvilke gravsteder som det av militære hensyn var ønskelig å få flyttet. Hærens overkommando sendte ut en anmodning til alle distriktskommandoene, våpeninspektørene og fagmyndighetene om å sende inn sine uttalelser så snart som mulig. ${ }^{157}$

I forbindelse med spørsmålet om flytting og samling av krigsgraver i SørNorge innhentet Sjøforsvarets overkommando uttalelser fra ulike militære

155 SAH, Östopland I.R.5. «Krigsgraver». Dovre 09.08.1947.

156 RA, Krigsgravtjenesten, eske 26-35. «Ad. Flytting av russergraver». Feltpresten Østlandet. Oslo 05.09.1949.

157 SAT, Kirkevergen i Trondheim, krigsgraver, E1. «Flytting og sammendraging av krigsgraver i Norge». Oslo 19.12.1949. 
Dombås burde flyttes fordi de lå tett inntil gjerdet til et ammunisjonslager. Når det gjaldt Jørstadmoen, mente generalinspektøren for Hærens samband at krigskirkegården lå avsides i forhold til det militære anlegget i nærheten, den la ikke beslag på noe stort område og det var gjort en stor innsats både fra militær og sivil side for å få kirkegården ordnet i god stand. Han mente derfor at den burde beholdes selv om det ikke var ønskelig å ha den så nær ekserserplassen. Hærens overkommando var enig i at militære grunner tilsa flytting av gravene på de ovennevnte stedene. Når det gjaldt Jørstadmoen, kunne den gis lavere prioritet enn de andre på grunnlag av generalinspektørens uttalelse. Representanter for Hæren på Sørlandet mente at gravene på Evjemoen burde flyttes. Det ble antatt at Luftforsvaret i dette området ville ta standpunkt til gravene på Sola og Soma. Feltpresten i området opplyste at det allerede var foretatt mindre flyttinger i distriktet, og Stavanger formannskap hadde i slutten av november 1949 avslått en søknad om flytting av tolv russergraver fra Soma til Eiganes kirkegård. På Vestlandet og i Trøndelag var det ingen krigsgraver Hæren ønsket å flytte av militære grunner. ${ }^{159}$

Når det gjaldt gravene på Haslemoen, ba Forsvarsdepartementet om en uttalelse fra Forsvarsstaben om det var nødvendig med en flytting av gravene av militære grunner. En egen komité var nedsatt for å sette i stand en del krigsgraver på Åsnes og Haslemoen med tanke på å reise bautaer, og de $\varnothing n s k e t$ å vite om gravene skulle bli flyttet. ${ }^{160}$ Distriktskommando Oppland informerte om at gravene lå utenfor feltet som var planlagt som fremtidig militært område. Regimentet kunne ikke se at gravene var til noe hinder for utbyggingen og anvendelsen av det militære området på Haslemoen. ${ }^{161}$ Forsvarsstaben skrev i sin uttalelse at de ikke fant det nødvendig å flytte gravene av militære grunner. De viste også til at det var vanskelig å foreslå at gravene ble flyttet når forberedelsene til reisingen av minnesmerket snart var klare. På bakgrunn av dette mente Forsvarsstaben at det var viktig at de fikk slike saker forelagt på et tidlig tidspunkt for å ikke føle seg bundet av arbeid som allerede var satt i gang. Deres oppfatning var at fremmede krigsgraver i størst mulig grad burde bli flyttet fra militære områder, dels av hensyn til militære øvelser og dels av sikkerhetsmessige hensyn. Krigsgravene ville lett kunne utnyttes som foranledning til opphold i etterretningsøyemed i nærheten av militære områder i form av besøk og høytideligheter ved gravene, hevdet

159 RA, RAFA-2018/D/Da/L0026. «Flytting og sammendraging av krigsgraver i Norge». Oslo 26.01.1950.

160 RA, Krigsgravtjenesten, eske 26-35. "Ad russergraver Haslemoen. Forsvarsdepartementet». Oslo 24.11.1949.

161 RA, Krigsgravtjenesten, eske 26-35. «Ad russergraver Haslemoen». DKO. Oslo 08.12.1949. 
Forsvarsstaben. ${ }^{162}$ Forsvarsstaben gikk langt i å definere hvilke graver som burde bli flyttet selv om de ikke lå på militært område.

Luftforsvaret var opptatt av å flytte gravene i Sør-Norge. Av militære hensyn var det ønskelig å flytte graver som lå vest for stasjonsområdet på Gardermoen. Gravene lå på privat grunn i Nannestad, og nord for stasjonsområdet ved Gardermoen vaskeri på statens grunn. I begge tilfellene lå gravene utenfor Gardermoen flystasjons område, og derfor var det ønskelig at plasskommandanten uttalte seg om saken. Det er ingen dokumenter som viser plasskommandantens oppfatning av saken. Når det gjaldt Rygge flystasjon, var det ikke sovjetiske graver i dette området, men sivile myndigheter opplyste at en polsk krigsfange var gravlagt på Rygge kirkegård. I Stavern var det 40 graver i luftkommandoens leir ved Fredriksvern verft som det var meget ønskelig å få flyttet. Årsaken var at gravene opptok en stor del av ekserserplassen som befalsskolen brukte til sine øvelser. Plassen var blitt mindre på grunn av bygging av et nytt hus på området, og derfor var det høyst påkrevd at gravene ble flyttet. I tillegg ble det påpekt at gravene lå like inntil befalsskolens forlegning. ${ }^{163}$ Generalinspektøren for Luftforsvaret uttalte at 39 sovjetiske og fem tyske krigsgraver på Fredriksvern verft var til hinder for tjenesten og måtte flyttes. Han mente også at pietetsmessige hensyn burde tilsi at gravene ble flyttet. ${ }^{164}$ Luftforsvarets overkommando foreslo på grunnlag av dette at gravene i Stavern, Gardermoen og Lista ble flyttet. I tillegg var det ønskelig å flytte krigsgravene som befant seg på Eggemoen. Overkommandoen mente at det ikke var nødvendig å flytte den polske graven på Rygge kirkegård. ${ }^{165}$

Ved Knaben gruver i Kvinesdal døde fem fanger den 5. mars 1943. Krigsfangene ble satt til å rydde udetonerte bomber etter et flyangrep mot gruvene. Under dette arbeidet sprengtes en bombe og de fem fangene mistet livet. Sognepresten i Fjotland fikk tillatelse fra tyskerne til å gravlegge de sovjetiske ofrene, men gravene ble kort tid etter gravd opp igjen av tyskerne. I 1945 gikk det rykter om at ofrene var gravlagt i en potetåker i Kvås. Sognepresten informerte biskopen i Agder at det var et ønske fra lokalbefolkningen at disse døde måtte få sitt siste hvilested ved Netlandsnes kapell om ikke annet var bestemt. Først i 1947 skrev feltpresten for Distriktskommando Sør om en eventuell flytting av gravene fra Kvås til Knaben. Det stemte ikke at gravene

162 RA, Krigsgravtjenesten, eske 26-35. «Ad russergraver Haslemoen». Oslo 23.12.1949.

163 RA, RAFA-2018/D/Da/L0026. "Flytting og sammendraging av krigsgraver i Norge». Fornebu 27.01.1950.

164 RA, RAFA-2018/D/Da/L0026. «Flytting og sammendraging av krigsgraver i Norge». Oslo 01.02.1950.

165 RA, RAFA-2018/D/Da/L0026. «Flytting og sammendraging av krigsgraver i Norge». Oslo 08.02.1950. 
lå i en potetåker, men det var likevel ikke et passende gravsted. Den sovjetiske representanten Rylnikov så helst at slike graver ble flyttet til et sentralt sted, og det var ønskelig at de ble flyttet til Kristiansand. Feltpresten gjorde ham oppmerksom på at en så lang flytting var det ikke mulig å gjennomføre. Han foreslo i stedet at gravene ble flyttet til Lyngdal kirkegård. Rylnikov gikk med på dette. Om gravene likevel skulle flyttes til Knaben, mente feltpresten at det var viktig å undersøke om russerne hadde noe imot dette, siden dette var et svært avsides sted. Feltpresten viste for øvrig til at det ville bli billig å ha gravene i Knaben siden en kunne gå ut fra at lokalbefolkningen ville ta seg av vedlikeholdet og passe på gravene. Feltpresten foreslo også at Knaben gruver kunne dekke utgiftene til transport av de oppgravde ofrene. ${ }^{166}$ Brevet fra feltpresten ga tydelig inntrykk av at Forsvaret ønsket minst mulig ansvar for vedlikeholdet av de sovjetiske gravene, og at de ønsket å begrense utgiftene knyttet til flytting av graver. Kort tid etter at den første samlingen av de sovjetiske gravene startet, ble både leirene og gravene sentrale temaer i de diplomatiske forbindelsene mellom Norge og Sovjetunionen.

166 RA, Krigsgravtjenesten, eske 26-35. «Ad russergravene i Kvås, Lyngdal». Kristiansand S. 12.02.1947. 


\section{Diplomatisk dragkamp og norsk- sovjetisk krigsfangekommisjon}

Etter initiativ fra sovjetisk side ble en norsk-sovjetisk krigsfangekommisjon nedsatt den 15. februar 1946. Kommisjonens mandat var å besøke de viktigste tidligere leirene og arbeidsplassene for sovjetiske krigsfanger i Norge. I utgangspunktet var kommisjonen nedsatt for å undersøke alle tidligere fangeleirer for sovjetiske krigsfanger, men fikk etter hvert også oppgaver tilknyttet vedlikehold av sovjetiske krigsgraver. Målet var å samle inn opplysninger om krigsfangenes beskjeftigelse, arbeidsforhold og opplysninger om krigsfangene som var blitt drept av tyskerne. Ifølge de første rapportene fra kommisjonens norske medlemmer viste de sovjetiske medlemmene liten interesse for krigsfangenes skjebne. De var særlig interessert i å få opplysninger om antallet arbeidstimer og verdien av det utførte arbeidet, samt andre opplysninger til bruk for beregningen av hvilke verdier sovjetiske krigsfangers arbeid måtte ha tilført Norge. Sovjetiske representanter beregnet blant annet antallet dagsverk som var utført ved Isrenna fangeleir i Tromsø, og at kostnadene på en meter grøftearbeid var 14 kroner. På spørsmål fra Utenriksdepartementet om hensikten med å innhente disse opplysningene, ble det fra sovjetisk side erklært at det ikke var meningen å fremsette noe erstatningskrav overfor Norge tilsvarende verdien av arbeidet.

Etter Utenriksdepartementets oppfatning hadde de sovjetiske medlemmene i kommisjonen opptrådt på en meget arrogant og uverdig måte, slik at det til stadighet var konflikter innad i kommisjonen mellom de norske og sovjetiske medlemmene. En vesentlig grunn til dette skyldtes meningsforskjell om forstålsen av kommisjonens mandat, og i første halvdel av 1947 
var kommisjonen ikke i virksomhet på grunn av uenigheter som særlig gjaldt hvilke leirer som skulle besøkes. I instruksen til de norske medlemmene het det at befaringer skulle foretas i de viktigste krigsfangeleirene, hvilket etter norsk oppfatning betydde leirer hvor det hadde sittet minst 100 sovjetiske krigsfanger. Det lyktes til slutt å få den sovjetiske ambassaden til å godta det norske synet på mandatet. Til tross for at kommisjonen hadde fått anledning til å besøke de viktigste stedene hvor det var kjent at det hadde vært eller fremdeles lå sovjetiske krigsfanger begravd, ble det stadig fra sovjetisk side klaget over at de ikke hadde fått alle tilgjengelige opplysninger. Fra norsk side hadde man gitt de lokale opplysningene til den sovjetiske ambassaden, men dette så ikke ut til å tilfredsstille dem. Ambassaden påpekte til stadighet at de måtte få anledning til å reise rundt og kontrollere opplysningene og eventuelt skaffe nye. Ambassaden fortsatte også å rette direkte henvendelser til de lokale myndighetene, slik at departementet ved et par anledninger måtte henstille ambassaden om å forholde seg til Utenriksdepartementet i alle spørsmål som angikk de sovjetiske krigsfangene i Norge. ${ }^{167}$

Etter planen skulle den norsk-sovjetiske kommisjonen besøke områder underlagt Distriktskommando Oppland i dagene 25.-27. august 1947. I forbindelse med besøket måtte det derfor bli avgjort om kommisjonen fikk tillatelse til å besøke militære områder. Stedene dette gjaldt var Gardermoen, Hamar, Lillehammer, Jørstadmoen, Elverum, Rena og Haslemoen. På Hamar ble det avklart at en offiser fra distriktskommandoen skulle følge kommisjonen. På Lillehammer og Jørstadmoen ble plasskommandanten bedt om å sørge for at det var en offiser til stede under besøket. Ved besøket på Heradsbygd og Rena (Løset) ble infanteriregiment 5 bedt om å stille med en offiser. På Haslemoen var det tilstrekkelig at oppsynsmannen møtte opp. Ved et eventuelt besøk på Gardermoen skulle plasskommandanten bli informert direkte. I tillegg til dette var det også ønskelig at det på hvert sted var til stede en sivilperson som kunne gi førstehånds opplysninger om hvordan de sovjetiske krigsfangene hadde det under okkupasjonen. ${ }^{168}$

I kommisjonens protokoll av 19. desember 1947 ble det oppgitt at det var registrert mer enn 10000 sovjetiske krigsfanger gravlagt i Norge. Kommisjonen fremhevet at ikke alle krigsfanger som døde, ble gravlagt og registrert, derfor antok de at antallet døde krigsfanger måtte være betydelig høyere. ${ }^{169}$

167 RA, Krigsgravtjenesten, eske 26-35. Notat. «De sovjetiske krigsgraver i Norge». Utenriksdepartementet. Oslo 02.02.1952.

168 SAH, I.R.5, jnr. 1451/47. «Tillatelse til aa besöke militäre omraader m.v. for den norsk-russiske krigsfangekommisjon». Aker gård, Hamar 14.08.1947.

169 RA, Krigsgravtjenesten, eske 26-35. «Protokoll for den blandete norsk-sovjetrussiske kommisjon for undersøkelse av leve- og arbeidsvilkårene blandt tidligere sovjetkrigsfanger som i 1941-45 var i tysk-facistisk fangenskap i Norge». 19.12.1947. 
Den norsk-sovjetiske kommisjonen publiserte et kommuniké i 1948. Her ble det påpekt at fangene ble holdt i konsentrasjonsleirer og andre spesielle leirer stort sett under umenneskelige forhold. Videre skrev kommisjonen at tyskerne satte seg ut over de alminnelige folkerettslige anerkjente reglene for behandling av krigsfanger. Det var praktisk talt fullstendig mangel på medisinsk hjelp for syke fanger. Den høye dødeligheten var en følge av sult, kulde, usanitære forhold og umenneskelig behandling. I mange tilfeller var behandlingen av de sovjetiske krigsfangene fra tysk side av en slik art at den måtte sees som et uttrykk for en bevisst utryddelsespolitikk, mente kommisjonen. ${ }^{170}$

\subsection{Uoffisielle sovjetiske besøk}

Feltpresten i Distriktskommando Trøndelag, Trygve Marken, kontaktet Sentralkontoret for krigsgraver for å fortelle om et besøk fra den sovjetiske ambassaden. M. Cherkasov hadde besøkt feltpresten sammen med kirkevergen i Trondheim. Cherkasov hadde sagt at han var interessert i at de sovjetiske gravene ble ordnet allerede samme høst. Han ønsket at gravene som lå utenfor en kirkegård, og som inneholdt flere enn ca. 30 ofre, fikk ligge, mens de med et færre antall ble flyttet inn på kirkegårdene. Dersom det stod om penger, ville ambassaden hjelpe. ${ }^{171}$ Dette viser at både Sentralkontoret og Distriktskommando Trøndelag ikke var forberedt på besøket fra ambassaden. Det at kirkevergen var involvert, kan tyde på at ambassaden kun hadde kontaktet lokale og ikke sentrale myndigheter før besøket. Kort tid etter dette ba feltprest Finn Guttormsen ved Sentralkontoret for krigsgraver om at Forsvarsdepartementet ga egne retningslinjer for forholdet til fremmede lands representanter. Årsaken til dette var at feltprestene ved distriktskommandoene i Nord-Norge, Trøndelag og Vestlandet hadde kontaktet Sentralkontoret etter besøk fra sovjetisk side. Feltprestene hadde rapportert om representanter fra den sovjetiske ambassaden som inspiserte sovjetiske krigsgraver, og hadde kommet med forslag for ordning av gravene. Guttormsen viste også til at en sovjetisk kommisjon nylig hadde besøkt krigskirkegårder på Østlandet. ${ }^{172}$

${ }^{170}$ RA, Krigsgravtjenesten, eske 26-35. «Kommuniké fra den blandete Norsk-Sovjetiske krigsfangekommisjon om dens arbeid med å undersøke leve- og arbeidsvilkårene for sovjetrussiske borgere i tysk krigsfangeskap i Norge.» 28.04.1948.

171 RA, Krigsgravtjenesten, eske 26-35. Notat, feltpresten DKT. Trondheim 26.08.1947.

172 RA, Krigsgravtjenesten, eske 26-35. Notat, Sentralkontoret for krigsgraver. Oslo 05.09.1947. 
Hverken Forsvarsdepartementet eller Utenriksdepartementet hadde kjennskap til at noen offisiell sovjetisk kommisjon hadde foretatt, eller hadde planer om å foreta, reiser i Nord-Norge for å undersøke sovjetiske krigskirkegårder. ${ }^{173}$ Utenriksdepartementet hadde tidligere foreslått at eventuelle sovjetiske besøk skulle bli henvist til Forsvarsdepartementet, men at det ikke burde legges hindringer for selve inspeksjonen av gravene. ${ }^{174}$ Samtidig rapporterte sjefen for Distriktskommando Nord-Norge, general Arne Dahl, at han hadde lest $\mathrm{i}$ avisene at sovjetiske kommisjoner reiste rundt i Norge for å se på sovjetiske krigskirkegårder. Hvis slike reiser skulle gjennomføres i Nord-Norge, foreslo han at en offiser fra Distriktskommando Nord-Norge fungerte som reisefører for å rettlede kommisjonene i deres arbeid. De hadde oversikt over i alt 90 gravsteder for sovjetiske statsborgere i Nord-Norge, og generalen mente en burde være lokalkjent for å kunne planlegge en rasjonell reise til så mange steder. ${ }^{175}$

Norske myndigheter var skeptiske da den sovjetiske ambassadens representanter gjennomførte nok et uoffisielt besøk i Nord-Norge i slutten av august 1948. Kommandørkaptein A. Sokolov reiste først innlands i Troms for å undersøke gravene. På vegne av den sovjetiske ambassaden ga han penger til vedlikehold av gravstedene på Kvesmenes, Skibotn, Bardufoss og Setermoen. Sokolov ønsket etter reisen å flytte likene som lå ved Takvann i Troms til Skjold i Øverbygd. Han var veldig misfornøyd med det han beskrev som den «ytterst slette forfatning de russiske gravsteder var i». ${ }^{176}$

Under reisen til Troms innland fikk Sokolov beskjed om at han dessverre ikke kunne foreta den planlagte turen før de formelle sidene ved besøket var avklart. General Dahl hadde erklært Troms innland som militært område under øvelsene som var i gang. Sokolov fikk derfor ikke tilgang til Bardufoss flyplass uten at det forelå tillatelser til dette fra Luftforsvarets overkommando. Etter dette hevdet han at han hadde snakket med den sovjetiske ambassadøren, som hadde informert ham om at han kunne fortsette turen. Ambassadøren skulle angivelig ha fått tillatelse fra Utenriksminister Halvard Lange til at turen til Sokolov kunne fortsette. Sokolov fikk da beskjed fra Distriktskommando Nord-Norge at han kunne reise, men ikke på militært område. Han ba om å få snakke med general Dahl. Sokolov hevdet overfor Dahl at han hadde fått beskjed om at Kvesmenes ikke var militært område,

173 RA, Krigsgravtjenesten, eske 26-35. «Russiske krigsgraver i Nord-Norge». Udatert, men journalført 05.12.1947.

174 RA, Krigsgravtjenesten, eske 26-35. «Utenlandske representanters inspeksjon av krigsgraver». Oslo 30.09.1947.

175 RA, Krigsgravtjenesten, eske 26-35. «Russiske krigsgraver i Nord-Norge». Harstad 30.09.1947.

176 RA, Krigsgravtjenesten, eske 26-35. Rapport. Tromsø 29.08.1948. 
men den norske kapteinen som var med, mente at dette var løgn, siden han ikke hadde uttalt seg om Kvesmenes i denne sammenhengen. ${ }^{177}$

Sokolov fikk likevel tillatelse av general Dahl til å reise til Kvesmenes, men han fikk ikke tillatelse til å begynne på turen i Troms innland før 27. august. Han var svært irritert over at han ble stoppet og nevnte stadig at to turister hadde reist fra Narvik via innlandet og til Tromsø mens øvelsen pågikk. Han viste også til at den amerikanske marineattacheen fikk reise fritt i Nord-Norge. På Kvesmenes deltok lensmannen på møtet med Sokolov. Lensmannen kom med en del uttalelser om kommunister som irriterte Sokolov. Under møtet med lensmannen tok han frem et håndskrevet dokument på russisk. Dokumentet beskrev de sovjetiske gravstedene. Massegraven ca. en kilometer sør for Skjold i Øverbygd var ikke nevnt i dokumentet til tross for at representanter for den sovjetiske ambassaden hadde inspisert de sovjetiske gravene der sommeren året før. Dagen etter fikk han fortsette reisen. Reisen fortsatte med besøk til gravstedene i Skibotn, Lulle, Øvergård, Sagelv, Vassmo ved Takvann og Skjold. Først hadde han planer om å reise med fly fra Bardufoss til Harstad, men ombestemte seg og reiste til Narvik og herfra med bil til Bodø. Den norske kapteinen fulgte alle bevegelsene til Sokolov og rapporterte til general Dahl. I rapporten ble det vist til at Sokolov nevnte en rekke norske offiserer under turen, og de fleste av disse betegnet han som «gode». Det var dessuten tydelig at han mislikte general Dahl. Sjøforsvaret rapporterte til slutt at han også hadde stilt flere spørsmål om Luftkommando Nord-Norge og deres sjøflyhavn. ${ }^{178}$

Sjøforsvarets kommando i Nord-Norge skrev etter besøket at de sovjetiske representantene Sokolov og Prokhorow forsøkte å gi besøket en offisiell karakter ved å avlegge visitter hos admiralen og fylkesmannen for å be om hjelp til transport og andre oppgaver. Nordmennene mente at dette virket mot sin hensikt. Sokolov fikk som tidligere omtalt tillatelse av general Dahl til å gjennomføre en inspeksjonsreise til Kvesmenes i Troms. Av sikkerhetshensyn ble han sendt inn med båt til Kvesmenes sammen med liaisonoffiser kaptein Christensen. I Harstad og Tromsø hadde de to sovjetiske representantene oppsøkt kjente kommunister, og Sjøforsvaret rapporterte etter besøket at det var holdt møter for kommunister flere steder. De norske militære representantene var åpenbart mistenksomme overfor de sovjetiske representantenes hensikt med besøket, og mente blant annet at de var veldig ivrige etter å få vite om noen utenlandske militære overvar norske militære mobiliseringsøvelser. Av

\footnotetext{
177 RA, Krigsgravtjenesten, eske 26-35. «Rapport om ledsagelse av kommandörkaptein A. Sokolov på tur i Troms innland». Tromsø 30.08.1948.

178 Ibid.
} 
hensyn til sikkerheten foreslo Sjøforsvaret at utenlandske offisielle utsendinger burde anmodes i god tid før planlagte reiser til Nord-Norge om å gi beskjed om dette til sentrale myndigheter. Forsvaret i Nord-Norge måtte få informasjon om slike innvilgede reiser i god tid på forhånd. Dette ble gjort for å unngå at en fremmed makt "laver et påskudd» av en eller annen art. Til slutt påpekte Sjøforsvaret at de sovjetiske krigsgravene lå altfor strategisk til, og at de derfor burde flyttes til et sentralt og nøytralt sted. ${ }^{179}$ Alle rapportene fra Sjøforsvaret ble sendt med et notat merket «strengt hemmelig» til Forsvarsdepartementet, Forsvarsstaben og stabssjefen ved Hærens overkommando. Notatet viser at Sjøforsvaret ønsket at de sovjetiske gravene skulle samles på ett sted for å motvirke den årvisse inspeksjonen av de spredte gravene. ${ }^{180}$

I Forsvarsdepartementet var man kritisk til at de to sovjetiske representantene hadde rettet direkte henvendelser både til sivile og militære myndigheter. Det var derfor et behov for å gi uttrykk overfor ambassaden at disse henvendelsene var «ikke helt i sin orden». Det ble påpekt at man kunne velge en forholdsvis nøytral form og bare henvise til samtalen som Sokolov hadde hatt med fylkesmannen i Tromsø, og gjøre ambassaden oppmerksom på at alle henvendelser omkring krigsgravene burde skje gjennom Utenriksdepartementet. Det måtte innskjerpes overfor de sivile og militære myndighetene at de ikke skulle foreta detaljerte forhandlinger med sovjetiske representanter. ${ }^{181}$ Utenriksdepartementet kontaktet deretter den sovjetiske ambassaden og viste til klagen fra sovjetisk side om at enkelte at gravplassene ikke ble tilfredsstillende ivaretatt. Ambassaden ble bedt om å rette alle henvendelser angående gravene til Utenriksdepartementet, som ville legge dem frem for Sentralkontoret for krigsgraver i Forsvarsdepartementet. Det var ikke nødvendig å ta direkte kontakt med lokale myndigheter siden de ikke hadde fullmakt til å ta beslutninger vedrørende gravene, var beskjeden fra Utenriksdepartementet til ambassaden. ${ }^{182}$

På bakgrunn av det uoffisielle besøket sendte forsvarsminister Jens Christian Hauge instrukser til Forsvarsstaben, Hæren, Sjøforsvaret og Luftforsvaret angående utenlandske representanters inspeksjon av krigsgraver. Her ble de lokale militære myndighetene anmodet om ikke å ta opp detaljerte forhandlinger om ordning av krigsgraver, men henvise vedkommende representant til sentralmyndighetene i Oslo ved besøk av sovjetiske og andre utenlandske representanter. Hauge viste videre til Justisdepartementets fortrolige skriv til politimestrene. Departementet hadde tidligere i et fortrolig rundskriv av 22.

179 RA, Krigsgravtjenesten, eske 26-35. «P.M. Sjøforsvarskommando Nord». Tromsø 31.08.1948.

180 RA, Krigsgravtjenesten, eske 26-35. «Uoffisielt besøk av ambassade-attacheer». Tromsø 02.09. 1948.

181 RA, Krigsgravtjenesten, eske 26-35. «Russernes inspeksjon av krigsgraver».31.08.1948.

182 RA, Krigsgravtjenesten, eske 26-35. Notat, Utenriksdepartementet. Oslo 03.09.1948. 
april 1947 bedt politiet om ikke å svare på spørsmål fra fremmede representanter og utlendinger ellers om norske forhold, registre, materiell, bygninger og anlegg. Dette ble også innskjerpet ytterligere ved at politiet ble bedt om ikke å svare på spørsmål, eller forhandle med slike personer om forhold fra okkupasjonstiden, selv om dette bare gjaldt forlegninger, eksekusjonssteder, gravplasser eller lignende. Politiet skulle ikke ta imot offisielle representanter som ikke på forhånd var behørig anmeldt gjennom sentraladministrasjonen, og de skulle ikke svare direkte på forespørsler fra representantene. Disse skulle henvises til Utenriksdepartementet eller Forsvarsdepartementet, eventuelt Justisdepartementet. Forsvarsdepartementet bestemte at de lokale militære myndighetene måtte forholde seg på samme måte som politiet. ${ }^{183}$

Norske myndigheters skepsis til den sovjetiske reisevirksomheten i landet i tilknytning til besøk av gravsteder økte stadig. Statssekretær Dag Bryn i Forsvarsdepartementet var kritisk til hvordan de to sovjetiske representantene hadde henvendt seg til ulike sivile og militære myndigheter under sin reise i Nord-Norge. Utenriksdepartementet hadde ved besøk fra sovjetisk side året før sagt klart ifra til den sovjetiske ambassaden at denne typen henvendelser måtte rettes til Utenriksdepartementet, som i sin tur ville legge det frem for Sentralkontoret for krigsgraver i Forsvarsdepartementet. I tilknytning til slike besøk av sovjetiske og andre utenlandske representanter hadde Utenriksdepartementet bedt Forsvarsdepartementet om å sørge for at de lokale militære myndighetene ikke tok opp detaljerte forhandlinger om ordning av krigsgraver, men henviste disse til sentralmyndighetene i Oslo. Bryn påpekte også at det burde gis nøyaktige innberetninger av denne typen besøk. ${ }^{184}$

Fylkesmannen i Finnmark ga i 1948 uttrykk for bekymring for sovjetiske representanters besøk overfor utenriksminister Halvard Lange. Fylkesmannen var særlig kritisk til at slike besøk gjerne var uanmeldte. Han mente det virket noe eiendommelig at den sovjetiske ambassaden sendte sine folk over hele landet uten å informere om det på forhånd. Han ønsket derfor at det ble gitt egne retningslinjer for hvordan man skulle, eller ikke skulle motta slike besøk. Fylkesmannen var av den oppfatning at den primære hensikten med slike besøk var å komme i kontakt med sine politiske meningsfeller. I hans møte med den sovjetiske representanten oberstløytnant Prokhorow kom det klart frem at han var blitt informert av kommunister i Finnmark. Han viste også til at Sokolov var sendt på en reise i Troms fylke i samme ærend. ${ }^{185}$

183 RA, Krigsgravtjenesten, eske 26-35. «Operasjon asfalt. Utenlandske representanters inspeksjon av krigsgraver». 06.11.1948.

184 RA, Krigsgravtjenesten, eske 26-35. «Utenlandske representanters inspeksjon av krigsgraver». 06.09.1948.

185 RA, Krigsgravtjenesten, eske 26-35. Notat, Fylkesmannen i Finnmark. Vadsø 08.09.1948. 
Etter reisen i Nord-Norge hadde Prokhorow møte med Dag Bryn i Forsvarsdepartementet. Bryn påpekte overfor Prokhorow at det var unødvendig og ukorrekt av de sovjetiske representantene å ta direkte kontakt med lokale myndigheter angående sovjetiske gravers vedlikehold i Norge. Etter hans syn var det både i sovjetisk og norsk interesse at de fleste gravene ble samlet på mer sentrale steder i nærheten av sivil bebyggelse. Prokhorow var enig i dette. Bryn nevnte også at det var i det norske militærets interesse å få flyttet graver som lå direkte på norsk militært område. Prokhorow mente at dette ville resultere i store praktiske vanskeligheter fordi det dreide seg om et stort antall graver. Med hensyn til den senere praktiske ordningen av vedlikehold og eventuell oppgraving og flytting av lik antok Bryn at dette for Norges del burde bli en sivil oppgave. I de tilfellene hvor dette gjaldt militært område, ville departementet sørge for en ordning mellom sivile og militære myndigheter. Til slutt beklaget Prokhorow meget sterkt at det i en norsk avis ble gitt uttrykk for kritikk av at de sovjetiske militærattacheene hadde fått overvære en mobiliseringsøvelse. Hans oppfatning var at de i virkeligheten ikke hadde fått sett noe. Bryn svarte til dette at de sovjetiske representantene her i landet fikk se langt mer enn hva deres mann fikk se i Moskva, og at det måtte være en viss gjensidighet $\mathrm{i}$ disse forholdene. I notatet fra møtet skrev Bryn til slutt at han syntes krigsgravspørsmålet burde bli drøftet i regjeringen ved neste anledning. ${ }^{186}$

Distriktskommando Sørlandet hadde i 1950 besøk av oberst Petrenko. Han var kommet for å se på forholdene ved de sovjetiske kirkegårdene i Vanse. Det var gravlagt 14 sovjetiske krigsfanger på Vanse kirkegård og 170 på en egen kirkegård på Lista om lag tre kilometer sør for Vanse i et øde strandlandskap ut mot sjøen. Den sovjetiske ambassaden i Oslo hadde betalt en mann i Kristiansand for å sørge for vedlikeholdet av kirkegården, men resultatet var ikke blitt bra. Obersten var veldig misfornøyd med arbeidet og mente at ordningen var meget uheldig. Sjefen for Distriktskommando Sørlandet, Olaf Helset, mente at den beste løsningen var å flytte de 170 sovjetiske gravlagte til Vanse kirkegård. Han påpekte at dette også ville bli en billig ordning. Vanskeligheten med å velge denne løsningen var at ambassaden hadde lagt ned mye penger i den nåværende løsningen, og Helset mente de ville bli kritisert fra sovjetisk side når de skjønte at disse pengene hadde vært bortkastet. Obersten var også innom Grepstad kirkegård under besøket. Her hadde kommunen påkostet en liten og svært velstelt utsmykning av graven til tre sovjetiske krigsfanger. Obersten ble veldig rørt over å se hvor godt kom-

186 RA, Krigsgravtjenesten, eske 26-35. Notat. «Besøk av oberstløytnant Prokhorow i anledning russiske krigsgraver i Norge». Oslo 16.09.1948. 
munen hadde ordnet med gravstedet. Helset påpekte at det hadde vært mye snakk om at sovjetiske representanter hadde foretatt unødvendige reiser til de forskjellige gravstedene hvor hensikten hadde vært en helt annen enn å se til gravene. I dette tilfellet mente han at en slik mistanke var uberettiget. Flere i det norske følget hadde samme inntrykk av Petrenko og følte at oberstens reise ble gjennomført med tanke på de sovjetiske ofrene. Helset anbefalte at flyttingen av gravene på Lista ble godtatt hvis sovjetiske myndigheter ønsket å flytte gravene. Da besøket var over, uttrykte obersten irritasjon over at han ble fulgt av overvåkingsfolk overalt. ${ }^{187}$

Noen måneder senere besøkte oberst Tarasov samme område for å undersøke forholdene ved Marka (Lista) kirkegård. Han fikk tillatelse av militære myndigheter til å reise til kirkegården. Tarasov hadde ikke med seg tolk, og dette medførte noe vanskeligheter. En representant fra Distriktskommando Sørlandet forsøkte å forklare obersten at det ikke var riktig å samarbeide med tilfeldige privatpersoner i dette arbeidet, men heller kontakte de ansvarlige myndighetene i denne typen saker. Tarasov forklarte at han hadde avtalt med graveren og lensmannen på Vanse hvordan flyttingen av gravene fra Lista til Vanse og utsmykningen av gravstedet skulle utføres. Den sovjetiske ambassaden i Oslo var innstilt på å betale alle utgiftene. I tillegg til denne flyttingen skulle gravene på Oddernes kirkegård flyttes til Kristiansand kirkegård. Inntrykket fra norsk side var at oberst Tarasov gikk energisk inn for å ordne spørsmålene omkring de sovjetiske krigsgravene. ${ }^{188}$

\subsection{Norske myndigheters toårsplan for gravene}

Spørsmålet om flytting av gravene ble første gang tatt opp under en samtale mellom norske myndigheter og Sovjetunionens ambassadør i slutten av 1948. Ambassadøren bekreftet senere i juni 1949 at sovjetiske myndigheter var enige $\mathrm{i}$ at en burde søke å samle krigsgravene på sentrale steder, men de mente at det ikke var noen grunn til å flytte alle gravene fra de lokale kirkegårdene. Dette gjaldt særlig de gravene som var velstelte. Ved samme anledning ba den sovjetiske ambassadøren om å få et forslag fra norsk side og et overslag over omkostningene ved flyttinger. Ambassaden ba også om å bli satt i kontakt med lokale myndigheter for å sikre nødvendig assistanse for de sovjetiske representantene som skulle reise rundt og ordne med vedlikeholdet. I en note

187 NHM, 278. Krigsgravtjenesten, dokumentsamling. «Distriktskommando Sørlandet». Kristiansand S. 10.07.1950.

188 NHM, 278. Krigsgravtjenesten, dokumentsamling. «Ad. Krigsgraver». Avskrift. Kristiansand S. 22.11.1950. 
av 10. juli 1951 ble den sovjetiske ambassaden informert om at den norske regjeringen hadde vedtatt en toårsplan for istandsettelsen av sovjetiske krigsgraver, med sikte på en samling av gravene på to eller tre steder. Den norske stat ville betale alle utgiftene tilknyttet flyttingen, og det ble forventet at den sovjetiske ambassaden ville besørge vedlikeholdet av gravene i fremtiden. ${ }^{189}$

Toårsplanen til den norske regjeringen for samlingen av de sovjetiske krigsgravene, datert den 26. juni 1951, var omfattende. Forsvarsdepartementet hadde utarbeidet planen med tanke på en samling av samtlige sovjetiske krigsgraver i Norge, bortsett fra gravene på Vestre gravlund i Oslo. Planen omfattet flytting av 10704 graver fra 191 gravsteder. Gravene i de fem nordligste fylkene, i alt 8651, skulle flyttes i løpet av 1951 og de resterende om lag 2050 gravene skulle samles i løpet av sommerhalvåret $1952 .{ }^{190}$ Planen ble imidlertid endret. I juli 1951 informerte sjefen for Etterretningstjenesten, Vilhelm Evang, om at samtlige sovjetiske graver i de tre nordligste fylkene skulle samles i en grav i Vefsn, fortrinnsvis et sted langs forden. På dette tidspunktet var det ikke bestemt hvor gravene skulle flyttes da det ikke hadde vært tid til å finne et sted. For Sør-Norge skulle det etableres to gravsteder. Et for området Bergen-Gardermoen og sørover i området Kongsberg-Meheia, det andre for området Bergen-Gardermoen og nordover i området VågåLom-Skjåk. ${ }^{191}$

Den norske regjeringen informerte sovjetiske myndigheter 9. mai 1951 om planene om å flytte en del av krigsgravene med særlig sikte på å konsentrere gravene på færre steder. På dette tidspunktet ble det ikke nevnt at stedet var Tjøtta, fordi det ikke var funnet et egnet gravsted ennå. ${ }^{192}$ Høsten samme år protesterte sovjetiske myndigheter mot flyttingen av gravene og omtalte gravsamlingen som en «storstilt oppgraving av levninger etter sovjetiske soldater som døde på norsk territorium under frigjøringen av Norge fra de tysk-fascistiske okkupantene». ${ }^{193}$ Sovjetiske myndigheter hadde misforstått og trodde at oppgravingen omfattet sovjetiske soldater som døde i kamp på norsk jord. Uansett protesterte russerne for sent, og arbeidet med oppgravingen av de døde krigsfangene var allerede satt i gang.

189 RA, Krigsgravtjenesten, eske 26-35. Notat. «De sovjetiske krigsgraver i Norge». Utenriksdepartementet. Oslo 02.02.1952.

190 Ibid.

191 RA, RAFA-2018/D/Da/L0026. «Konsentrasjon av russiske krigsgraver». F.st.II. Jnr. 4422/51. Oslo, 04.07.1951.

192 Jf. Thor Helge Eidsaune, «Kirkegårdskrigen», i Materialisten. 1/2-01. Ifølge Eidsaune var det først den 2. august at den norske regjering opplyste at Tjøtta var gravstedet.

193 AVPRF, f.07, op.26, p. 47, d. 141, II. 1-4. «Utenriksministeriets verbalnote til Norges ambassade i USSR om flytting av sovjetiske krigsgraver i Norge, 01.10.1951». Original oversatt av Sven G. Holtsmark, i Norge og Sovjetunionen 1917-1955. Institutt for forsvarsstudier og Det russiske vitenskapsakademi, Oslo 1995: 461. 
I et utkast av noten fra Utenriksdepartementet som ble sendt i juli, påpekte departementet at det ikke ville være hensiktsmessig at representanter for den sovjetiske ambassaden gjennomførte de planlagte reisene til forskjellige deler av landet med den oppgaven som var angitt i ambassadens note av 31. mai 1951. ${ }^{194}$ Ambassaden oppga her at de ville ta kontakt med lokale myndigheter for å sikre nødvendig assistanse for de sovjetiske representantene som skulle reise rundt og ordne med vedlikeholdet av gravene. Norske myndigheter ønsket ikke at sovjetiske representanter skulle gis anledning til å gjennomføre slike reiser eller ta kontakt med lokale myndigheter angående gravene. Ambassaden ønsket snarest å begynne arbeidet med å sette gravene i stand. Når det gjaldt graver i militære soner og forbudte områder, mente ambassaden at også disse burde bli satt i stand. Ambassaden opplyste også at de ønsket å gjennomføre vedlikeholdsarbeidet på gravene ved å bytte ut trekorsene med gravsteiner med innskrift. På gravsteder der et større antall sovjetiske ofre var gravlagt, ønsket de å sette opp minnesmerker og gjerder. Alle utgiftene for dette arbeidet ville bli betalt av ambassaden. ${ }^{195}$

Den norske regjeringen beklaget at vedlikeholdet av de sovjetiske krigsgravene ikke var så godt. Ifølge regjeringen skyldtes dette for en stor del administrative vanskeligheter, at hovedgrunnen var gravenes store antall, og at de lå spredt over hele landet og til dels var vanskelig tilgjengelig store deler av året. Utenriksdepartementet hadde festet seg ved at den sovjetiske ambassaden hadde anslått antallet sovjetiske gravlagte i Norge til 12000 . Ifølge norske rapporter oversteg antallet ikke 11 541. Departementet mente at de ulike tallstørrelsene skyldtes forskjellig vurdering av det antallet som var gravlagt i fellesgraver, hvor tallmaterialet var mangelfullt. ${ }^{196}$

Fra Utenriksdepartementets side ble det nå påpekt at saken omkring de sovjetiske gravene begynte å få en alvorlig karakter. Sovjetiske myndigheter hadde bestemt seg for å holde saken mest mulig varm og bruke den som et ankepunkt mot den norske regjeringen, ble det hevdet. Departementet påpekte at russerne ville flytte færrest mulig graver, og at de ønsket selv å betale omkostningene ved vedlikeholdet av gravene. Det var også et ønske fra sovjetisk side å sette i stand graver i militære soner og forbudte områder. Russerne ønsket selv å inngå kontraktene med lokale folk om gjennomføringen av arbeidet med gravene. Det ble også uttalt at hvis de skulle gå med på

194 RA, Krigsgravtjenesten, eske 26-35. Notat, Utenriksdepartementet. Oslo, udatert juli 1951.

195 RA, Krigsgravtjenesten, eske 26-35. Avskrift, verbalnote. SSSRs ambassade. Nr. 49/51. Oslo 31.05.1951.

196 RA, Krigsgravtjenesten, eske 26-35. Notat, Utenriksdepartementet. Oslo, udatert juli 1951. 
ønskene fra sovjetisk side, ville det bety at de la alt til rette for organiseringen og kontrollen av et vidt forgreinet spionasjenett. Selv om departementet insisterte på at alt arbeid måtte foretas gjennom norske myndigheter, ville det bli vanskelig å nekte russerne å inspisere med jevne mellomrom det arbeidet som de selv betalte for. Til slutt påpekte departementet at det eneste effektive tiltaket for å stoppe de sovjetiske planene var at det snarest ble bevilget penger til en kraftig konsentrasjon av gravene. ${ }^{197}$

I en verbalnote den 22. august 1951 fra den sovjetiske ambassaden fikk Utenriksdepartementet beskjed om at sovjetiske myndigheter hadde innvendinger mot den vedtatte planen og gravflyttingen. På dette tidspunktet var imidlertid arbeidet allerede satt i gang og det ville medføre store vanskeligheter å stoppe arbeidet og endre planene. Norske myndigheter vurderte henstillingen fra ambassaden om å stoppe arbeidet, men bestemte at arbeidet med flyttingen av gravene i de tre nordligste fylkene måtte gjennomføres etter planen. Utenriksdepartementet forsikret den sovjetiske ambassaden om at arbeidet ville bli gjennomført på en så hensynsfull og ærbødig måte som mulig. I henhold til de instruksene som var gitt på dette tidspunktet, ville minnesmerkene ikke ble berørt av flyttingen. Utenriksdepartementet informerte likevel om at en rekke minnesmerker var i en slik forfatning at de antakelig burde bli erstattet med nye. Til slutt orienterte departementet om at transporten av likene til sentralgravplassen på Tjøtta var ventet å være avsluttet i løpet av oktober måned. ${ }^{198}$

Øverstkommanderende for Nord-Norge, general Dahl, sendte den 1. oktober 1951 følgende telegram til Forsvarsdepartementet:

Ad russiske krigsgraver. $Ø \mathrm{KN}$ frarår på det bestemteste noen forandringer i de nå fastlagte planer om flytning av russiske krigsgraver og sammendragning til et felles gravsted på Tjøtta. ${ }^{199}$

Foranledningen til telegrammet var en sovjetisk henvendelse angående arbeidet med flyttingen. Senere hadde Dahl dessuten blitt oppmerksom på en protest mot flyttingen av gravene som var gjengitt i pressen. Dahl fastholdt sitt synspunkt, at den sovjetiske henvendelsen ikke måtte gi anledning til noen forandringer i regjeringens standpunkt om å samle samtlige sovjetiske krigsgraver på krigskirkegården på Tjøtta. Han viste til at vedlikeholdet av disse gravene var en skam. Mange gravplasser lå spredt over hele NordNorge, og på svært avsidesliggende steder lå gravene uten tilsyn. Gjerder og

197 RA, Krigsgravtjenesten, eske 26-35. Notat, Utenriksdepartementet. «De sovjetiske gravsteder i Norge». Udatert.

198 RA, Krigsgravtjenesten, eske 26-35. Notat, Utenriksdepartementet. Oslo 19.09.1951.

199 RA, Krigsgravtjenesten, eske 26-35. Avskrift. «Russiske krigsgraver». Harstad 04.10.1951. 
gravkors var råtne, og gress og trær dekket gravene. Selv gravplasser ved større tettbebyggelser var ikke vedlikeholdt. Beliggenheten til mange graver gjorde vedlikeholdet til en meget vanskelig og kostbar oppgave, ifølge Dahl. Han påpekte at regjeringens beslutning om å samle samtlige gravplasser til en stor krigskirkegård var en verdig måte å løse saken på. Ved valget av Tjøtta var det langt fra valgt et «avsides sted», som den sovjetiske ambassaden hadde hevdet, mente Dahl. Han gikk langt i å trekke parallellene til Russland i valget av Tjøtta. Dahl skrev at dette tvert imot var stedet for et gammelt høvdingsete som hadde vært i full blomstring i mange hundreår på den tiden da Rurik erobret de slaviske stammer og opprettet begynnelsen på det nåværende Russland. ${ }^{200}$

Den sovjetiske ambassaden protesterte mot flyttingen av gravene og ba om at arbeidet ble stanset. Til dette svarte Utenriksdepartementet at arbeidet allerede var kommet så langt at flyttingen av gravene i de nevnte fylkene måtte gjennomføres etter programmet. I en note den 1. oktober 1951 protesterte sovjetiske myndigheter igjen mot flyttingen av de sovjetiske krigsgravene. De foreslo også at det ble nedsatt en norsk-sovjetisk kommisjon med oppdrag «å treffe tiltak for å bringe de sovjetiske krigsgraver i Norge i orden». ${ }^{201}$ Den norske regjeringen fremholdt i sitt svar den 10 . oktober at den gjerne ønsket å nedsette en slik kommisjon, men etter deres oppfatning burde kommisjonens oppgave være å utforme de endelige planene for anlegget og utsmykningen av den nye kirkegården på Tjøtta. I tillegg ønsket regjeringen at en slik kommisjon skulle drøfte gjennomføringen av samlingen av de sovjetiske krigsgravene i Sør-Norge. På sovjetisk side ønsket man ikke en kommisjon med et slikt mandat og fremholdt at dens oppgave måtte være å vedlikeholde gravene. De fremhevet samtidig som et vilkår for kommisjonens arbeid at all flytting av gravene måtte bli stoppet. Norske myndigheter viste til at samlingen av gravene i de tre nordligste fylkene var nærmest avsluttet, men at de øvrige planer for samling og istandsettelse ville bli stanset for at de kunne bli drøftet av den foreslåtte kommisjonen. ${ }^{202}$

Når det gjaldt arbeidet til den blandede kommisjonen, anså norske myndigheter det som hensiktsmessig at den skulle drøfte gjennomføringen av den varslede samlingen av gravene til sovjetiske borgere i Sør-Norge. ${ }^{203}$

200 Ibid.

201 RA, Krigsgravtjenesten, eske 26-35. Notat. «De sovjetiske krigsgraver i Norge». Utenriksdepartementet. Oslo 02.02.1952.

202 Ibid.

${ }^{203}$ AVPRF, f. 0116, op. 40, p. 160, d. 4, II. 13-19. «Utenriksministeriets verbalnote til Norges ambassade i USSR om flytting av sovjetiske krigsgraver i Norge, 7. desember 1951». Original oversatt av Sven G. Holtsmark, i Norge og Sovjetunionen 1917-1955. Institutt for forsvarsstudier og Det russiske vitenskapsakademi, Oslo 1995: 466. 
Den sovjetiske regjeringen avviste blant annet et mandat for kommisjonen, og de uttalte i en verbalnote av 31. oktober 1951 at:

Den norske regjering, som er enig i den sovjetiske regjerings forslag om å danne en blandet sovjetisk-norsk kommisjon, foreslår å gi kommisjonen som oppgave å diskutere de tekniske spörsmål i forbindelse med utformingen av gravplassen på Tjötta. Den sovjetiske regjering kan ikke være enig i dette, fordi det ikke kan og ikke må inngå i kommisjonens oppgave å samarbeide med de norske myndigheter til utslettelse av sovjetiske krigsmenns graver og gravsamlinger i Norge, en utslettelse som attpå til ledsages av en hittil uhört forhånelse av de sovjetiske krigsmenns lik. Kommisjonens oppgave må være å ta de skritt til vedlikehold av disse graver og grunnbetingelsen for dens arbeid må være at den utslettelsen av de sovjetiske krigsmenns graver som den norske regjering har arrangert, straks må opphöre. ${ }^{204}$

I sitt svar nøyde den norske regjeringen seg med å henvise til sin verbalnote av 10. oktober og ga uttrykk for et håp om at en blandet kommisjon kunne starte sitt arbeid så raskt som mulig. Sovjetunionens regjering sendte en ny note den 7. desember 1951 hvor de bekreftet at kommisjonen nå kunne nedsettes i betraktning av at flyttingen av gravene var innstilt. ${ }^{205}$ Den norsk-sovjetiske kommisjonens arbeid resulterte $\mathrm{i}$ at de opprinnelige norske planene ble noe modifisert.

\subsection{Alternativer til løsning av gravspørsmålet}

Utenriksminister Halvard Lange fremla i mars 1949 tre alternativer for hva som kunne gjøres med de sovjetiske krigsgravene i Norge. Første alternativ var at gravene ble samlet på felles kirkegårder fylkesvis, eller for større distrikter. Andre alternativ var at enkeltgraver, eller mindre grupper av graver, ble flyttet til steder hvor det allerede var samlet et større antall sovjetiske graver. Tredje alternativ var at ingen graver ble flyttet, men at alle uforsvarlig gravlagte ble flyttet til nærmeste kirkegård eller krigskirkegård. Lange ønsket en uttalelse om i hvilken utstrekning Sentralkontoret for krigsgraver ville kunne dekke utgiftene i den grad disse helt eller delvis skulle dekkes av norske myndigheter. ${ }^{206}$

204 RA, Krigsgravtjenesten, eske 26-35. «Notat til statsråd Hauge». 12.12.1951.

${ }_{205}$ RA, Krigsgravtjenesten, eske 26-35. Notat. «De sovjetiske krigsgraver i Norge». Utenriksdepartementet. Oslo 02.02.1952.

${ }_{206}$ RA, Krigsgravtjenesten, eske 26-35. «Russiske krigsgraver i Norge». Oslo 08.03.1949. 
I juni 1949 var den sovjetiske ambassadøren på besøk i Utenriksdepartementet for å drøfte de sovjetiske gravene i Norge. Ambassadøren påpekte at myndighetene i Moskva var enige i at man ønsket å få samlet de sovjetiske krigsgravene på sentrale steder. Men de mente ikke at det var grunn til å flytte alle graver fra lokale kirkegårder, og særlig ikke dem som var velstelte. Ambassadøren ba om å få et forslag fra norsk side vedrørende flytting av slike graver med overslag over omkostningene. Han ønsket også at flest mulig gravsteder skulle bli satt i stand i løpet av sommeren. Ambassaden hadde bidratt med økonomiske midler til ulike lokale myndigheter til istandsettelse og vedlikehold av gravene. ${ }^{207}$

Til tross for de sterke formaningene året før om at lokale myndigheter ikke skulle ha direkte kontakt med sovjetiske representanter, var det ingenting i notatet fra Utenriksdepartementet som tydet på at de var kritiske til den kontakten som tydeligvis hadde vært mellom norske lokale myndigheter og den sovjetiske ambassaden. Etter møtet sendte ambassadøren en liste over sovjetiske borgeres gravplasser i Norge. Listen var satt opp på grunnlag av materiale fra den sovjetiske repatrieringskommisjonen og det norske Forsvarsdepartementet i tiden 1945-1947, og kunne ikke regnes for å være fullstendig. Ambassadøren ønsket mer detaljerte rapporter over antallet gravplasser, hvilken tilstand de var i, omfanget av arbeidet som var nødvendig for å sette gravplassene i god stand og hvor store omkostningene for dette arbeidet ville bli. ${ }^{208}$

Kaptein Syvertsen ved Sentralkontoret for krigsgraver presenterte i juli 1949 et forslag for flytting av sovjetiske krigsgraver i Norge. Dette var det samme forslaget som utenriksminister Halvard Lange hadde fremlagt noen måneder tidligere. Distriktskontoret for krigsgraver i Nord-Norge oppga at det første alternativet ikke var mulig å gjennomføre i distriktene siden avstandene var for store. Valgte man dette, ville det bli svært kostbart. Distriktskontoret for Østlandet mente at alle graver i deres område burde samles på Jørstadmoen, med unntak av gravene på Vestre gravlund i Oslo. I dette distriktet var det på enkelte kirkegårder reist bautaer og minnesmerker som ikke burde flyttes. På Sørlandet var det enighet om at Eiganes og Vanse kirkegårder skulle opprettholdes som samlingsplasser. For Vestlandet ble Nygård kirkegård i Bergen valgt som samlingsplass. I Møre og Romsdal ønsket man å samle sovjetiske krigsgraver på Aukra, for Nord-Trøndelag i Falstadskogen i Skogn og i Sør-Trøndelag på Ørlandet og Oppdal. Til alternativ to ble flere steder innenfor hvert enkelt distrikt foreslått som samlingsplasser for gravene. Det ble videre påpekt at når

207 RA, Krigsgravtjenesten, eske 26-35. «Russiske krigsgraver». Utenriksdepartementet. Oslo 21.06.1949.

${ }^{208}$ RA, Krigsgravtjenesten, eske 26-35. Oversettelse. Notat, De Sovjetiske Sosialistiske Republikkers Forbunds Ambassade. Oslo 28.06.1949. 
det gjaldt forsvarlig utført vedlikehold av gravene, stod Nord-Norge en del tilbake. Syvertsen mente at dette skyldtes store avstander, vanskelig kommunikasjon og den lange tiden av året hvor gravene var lite tilgjengelige. Han mente likevel at interessen for dette arbeidet var levende i landsdelen. For de øvrige landsdelenes vedkommende var arbeidet godt i gang, og gravene ble godt vedlikeholdt. Som eksempel nevnte han at det på flere sovjetiske gravsteder var reist bautaer og minnestøtter. ${ }^{209}$ Hvis alternativet var at ingen graver ble flyttet, mente utenriksministeren at det ville resultere i at det ville være sovjetiske gravplasser på en rekke steder av stor militær betydning, særlig i Nord-Norge. Konsekvensen av dette var at man antakelig måtte gi sovjetiske representanter adgang til å inspisere også disse gravstedene. ${ }^{210} \mathrm{Og}$ Forsvaret ønsket å unngå gravsteder på militære områder. Forsvarsstaben ble informert om planene, men ønsket på dette tidspunktet at alle krigsgravene i Finnmark skulle flyttes til Sørøya utenfor Hammerfest. De ønsket også å ta stilling til hver enkelt større flytting av graver i Sør-Norge når dette ble aktuelt. ${ }^{211}$ For Forsvarsstaben var flyttingen av gravene i Sør-Norge åpenbart et spørsmål av sikkerhetsmessig art, slik det også var i Nord-Norge.

For Nord-Norge foreslo Hæren at krigsgravene til sovjetiske soldater og soldater som tilhørte Østblokken i første omgang ble flyttet bort fra områder av militær interesse. Forslaget innebar at gravene i Sør-Varanger herred, Kistrand herred, Alta herred, Talvik herred, hele Troms fylke og områdene tilknyttet Bodø og Narvik ble flyttet. Det ble også påpekt at det ut fra landmilitærets synspunkt ville være ønskelig å samle alle krigsgravene på ett sted, og Kvaløy ved Hammerfest og Senja ble foreslått som passende steder. Hærens overkommando var enig i ønsket om en slik flytting, men antok at flytting av alle gravene ikke var mulig. De foreslo derfor at gravene i Mosjøen, Mo i Rana og Troms fylke unntatt Nesmoen I og II ble beholdt. ${ }^{212}$

Forsvarsdepartementet ville ikke ha så mange gravsteder. Forslaget hadde først omfattet to gravsteder i Sør-Norge, et for området Bergen-Gardermoen og sørover i området Kongsberg-Meheia og den andre i området Bergen-Gardemoen og nordover i området Vågå-Lom-Skjåk. Under planleggingen av samlingen av gravene ble det fremhevet at en ytterligere konsentrasjon var en økonomisk fordel, fordi to tredeler av de sovjetiske gravene befant seg nord for den nordligste samleplassen i Forsvarsstabens forslag. Det ville være langt billigere å transportere de 2000 asfaltsekkene fra Sør-Norge til gravplassen på Tjøtta enn å bekoste mange små transporter til to forskjellige gravplasser i Sør-

209 RA, Krigsgravtjenesten, eske 26-35. «Russiske krigsgraver i Norge». 22.07.1949.

${ }_{210}$ RA, Krigsgravtjenesten, eske 26-35. «Russiske krigsgraver i Norge». Oslo 23.08.1949.

211 RA, Krigsgravtjenesten, eske 26-35. Notat 30.06.1951.

212 RA, RAFA-2018/D/Da/L0026. «Flytting og sammendraging av krigsgraver i Norge». Oslo 26.01.1950. 
Norge, ifølge departementet. Forsvarsstaben påpekte i tillegg at man ville spare de forholdsvis høye anleggsomkostningene samt eventuelle ekspropriasjonsomkostninger som ville være forbundet med opprettelsen av de to gravplassene i Sør-Norge. Den eneste nåværende gravplassen som ville bli beholdt på eksisterende sted, var Vestre gravlund i Oslo, som man antok at den sovjetiske ambassaden ville beholde. Planen gikk ut på en samling av samtlige sovjetiske krigsgraver i Norge, bortsett fra gravene på Vestre gravlund, til én sentral krigskirkegård i Vefsn-området. ${ }^{213}$

I juni 1951 hadde kaptein Syvertsen ved Sentralkontoret for krigsgraver et møte med den sovjetiske militærattacheen oberst Tarasov. I møtet ble det opplyst at den sovjetiske ambassaden ønsket å få satt samtlige sovjetiske krigsgravsteder i verdig stand innen utgangen av 1952. Alle utgifter ville bli betalt av ambassaden. Militærattacheen ønsket i denne anledning en liste over samtlige krigsgravsteder i landet. På denne listen ønsket han at det ble avmerket hvilke steder som lå innenfor militært område. Arbeidene innenfor militært område ville bli utført etter Sentralkontorets bestemmelser og anvisninger. For de øvrige krigsgravstedene var det ønskelig at Sentralkontoret formidlet arbeidet gjennom lokale myndigheter. Syvertsen viste til bestemmelser gitt av Forsvarsdepartementet at det ikke var mulig å formidle denne typen opplysninger direkte. Sentralkontoret hadde heller ikke forutsetning for å bedømme hva som var militært område. Syvertsen anmodet til slutt om at den sovjetiske militærattacheen ble gjort kjent med Forsvarsdepartementets bestemmelser i de videre planene for ambassadens planlagte arbeid med krigsgravene. ${ }^{214}$ Samme dag hadde Tarasov også et møte med oberstløytnant Hassel ved Forsvarsstaben om samme sak. Han påpekte her at den sovjetiske ambassaden ønsket svar på noten av 2. juni snarest. Russerne ønsket lister over gravene, og de ville ta vare på gravene selv. For de gravene som de ikke fikk adgang til, ville ambassaden vite hvordan vedlikeholdet skulle ordnes. Tarasov krevde at gravene de ikke fikk tilgang til, skulle være like godt vedlikeholdt som de gravene de fikk tilgang til. Ifølge ambassadens planer ville det bli sendt ut egne forhandlingsgrupper for å forhandle med stedlige myndigheter om istandsettelse og vedlikehold av gravene. Herunder nevnte Tarasov at siden det var sovjetiske soldater det dreide seg om, måtte hans assistenter bli med i disse forhandlingsgruppene. Etter møtet ba Hassel om at Forsvarsdepartementet ga de nødvendige direktivene blant annet i forbindelse med sovjetiske representanters reiser i Norge. ${ }^{215}$

213 RA, RAFA-2018/D/Da/L0026. «Plan utarbeidet etter oppdrag fra sjefen for Forsvarsdepartementet på grunnlag av beslutning fattet i Regjeringen den 26. juni 1951. VI. Sammendragning av gravplassene til en eller flere enheter». Udatert.

${ }^{214}$ RA, Krigsgravtjenesten, eske 26-35. «Besøk av den sovjetrussiske militærattaché den 19. ds. vedrørende russiske krigsgraver i Norge». Oslo 21.06.1951.

215 RA, Krigsgravtjenesten, eske 26-35. «Russiske krigsgraver». Forsvarsstaben 29.06.1951. 
Like etter Tarasovs møter med Sentralkontoret og Forsvarsstaben besøkte den sovjetiske ambassaderåden Michailov Utenriksdepartementet. Her tok han opp de to verbalnotene av 31. mai og 5. juni 1951 samt ambassadør Afanasievs møte med utenriksminister Halvard Lange. Han påpekte at de ikke hadde mottatt noe svar på verbalnotene. Utenriksdepartementet viste til at Sentralkontoret ikke var kjent med listen over graver som burde bli satt i stand i 1951, som var levert av Utenriksdepartementet med noten av 5. juni. Den sovjetiske ambassaden var nå klar til å sende ut to forhandlingsgrupper, en til Finnmark og en til Kristiansand (Lista). Ambassaderåden påpekte at gravenes tilstand var alt annet enn tilfredsstillende, og insisterte på at man ikke måtte forsinke saken ytterligere. Representanten fra Utenriksdepartementet var ikke forberedt på å gi noe formelt svar på de to verbalnotene, men de var oppmerksom på at ambassaden ønsket en rask behandling av saken. Han mente at det burde skje en viss samling av gravene som nå var spredt på så mange forskjellige steder. Ambassaderåden spurte to ganger om de to gruppene kunne dra på sin planlagte reise, men representanten fra Utenriksdepartementet svarte at det ikke ville være hensiktsmessig, og forsikret ambassaderåden om at han skulle få et hurtig svar i saken. ${ }^{216}$ På møtenotatet fra Utenriksdepartementet var det skrevet at det gikk ikke an å slippe de «russiske team» til. ${ }^{217}$

Regjeringen hadde informert sovjetiske myndigheter om planene for flytting av graver. På samme tidspunkt meldte likevel Utenriksdepartementet til den sovjetiske ambassaden at man ikke visste om det for tiden var aktuelt å flytte bestemte graver, bortsett fra gravene på Marka krigskirkegård på Lista. De oppga at flyttingen av gravene kort tid etter krigsslutt hadde kostet uforholdsmessig mye per grav. Av økonomiske grunner ville man derfor fra norsk side bare kunne sette i verk et fătall av de flyttingene som var ønskelige ut fra et praktisk og forsvarlig vedlikehold. Det var ønskelig å flytte et stort antall enkeltgraver og mindre samlinger av graver til nærmeste krigskirkegård eller ordinære kirkegård. Departementet antok også at det fra sovjetisk side var ønskelig å flytte gravene som lå på militært område, siden fremmede makters representanter eller deres sivile hjelpere ikke ville bli gitt adgang til å inspisere eller arbeide med gravplasser på militært eller forbudt område. I mange av disse tilfellene var det også pietetsmessige hensyn som tilsa at gravene burde flyttes. Utenriksdepartementet var ikke særlig villig til å bidra økonomisk. De ville gjerne bidra til å flytte graver i den grad dette var ønskelig hvis man fra sovjetisk side var villig til å dekke alle eller en vesentlig del av utgiftene som

216 RA, Krigsgravtjenesten, eske 26-35. Notat. Utenriksdepartementet. Oslo 22.06.1951.

217 RA, Krigsgravtjenesten, eske 26-35. «Sovjetrussiske krigsgraver i Norge». Utenriksdepartementet. Oslo 27.06. 1951. 
var forbundet med flyttingene. Det var hentet inn et foreløpig kostnadsoverslag der man antok at det ville koste ca. $75000 \mathrm{kr}$ å sette gravene i god stand, og ytterligere årlige vedlikeholdsutgifter ble fastsatt til ca. $50000 \mathrm{kr}$. Ifølge departementet ville vedlikeholdsutgiftene bli noe redusert når gravene ble samlet på færre kirkegårder. ${ }^{218}$

Korrespondansen mellom Forsvarsdepartementet og Kirkedepartementet viser tydelig hastverket i saken. Den 13. juli 1951 sendte Forsvarsdepartementet en fortegnelse til Kirkedepartementet over sovjetiske krigsgraver som lå på ordinære kirkegårder, og som det var aktuelt å flytte til sentralkirkegården på Tjøtta. Det ble opplyst at kaptein Arntzen ville besøke de enkelte gravstedene i løpet av juli, august og september for å samrå seg med de lokale myndighetene angående krigsgravene. Kirkedepartementet ble bedt om å sende et rundskriv for å informere helsemyndighetene tilknyttet de gravstedene hvor det var aktuelt med flytting. Forsvarsdepartementet ba om at saken ble behandlet omgående og fortrolig. ${ }^{219}$

I forbindelse med planene for oppgravingen av sovjetiske ofre i NordNorge var Kirkedepartementet opptatt av de strenge retningslinjene for flytting av lik. Etter lov om kirker og kirkegårder av 3. august 1897 måtte flytting av begravde bare foregå med samtykke fra Kirkedepartementet etter at det var innhentet uttalelse fra Helserådet. Det var en alminnelig regel at lik ikke måtte graves opp i månedene mai til september. I dette tilfellet var det klart at Forsvarsdepartementet hadde kontaktet Helsedirektoratet for å få lempet på disse bestemmelsene. Kirkedepartementet gikk i juli 1951 ut fra at det ikke var aktuelt med en øyeblikkelig likflytting, og at det derfor ikke var nødvendig å sende ut et rundskriv om dette. Kirkedepartementet fremhevet uansett behovet for informasjon fra Helsedirektoratets side om mulighetene til å lempe på de alminnelige bestemmelsene om likflytting. ${ }^{220}$ Kirkedepartementet fulgte lovverket og kunne ikke ta en rask avgjørelse i saken uten å ha vært i kontakt med Helsedirektoratet. De viste også til tidligere eksempler på flytting av andre nasjonaliteters krigsgraver. I merknadsfeltet på dokumentet fra Kirkedepartementet blir det oppgitt at de etter konferanse med Helsedirektoratet hadde samtykket i flytting av amerikanske krigsgraver i tiden mai til september i 1946.

218 RA, Krigsgravtjenesten, eske 26-35. Vedlegg. Utenriksdepartementet. Oslo 09.05.1951.

219 RA, Krigsgravtjenesten, eske 26-35. «Sammendragning av krigsgraver». Oslo, 13.07.1951.

220 RA, Krigsgravtjenesten, eske 26-35. «Sammendragning av krigsgraver». 18.07.1951. 


\section{3. «Operasjon asfalt»}

For norske myndigheter var det vanskelig å skaffe en eksakt oversikt over antallet sovjetiske statsborgere som hadde mistet livet i krigsårene. Den 9. mai 1951 sendte Utenriksdepartementet en liste til den sovjetiske ambassaden over de sovjetiske ofrene som det hadde vært mulig å identifisere. Departementet fremhevet at listen ikke kunne betegnes som fullstendig da man manglet en del opplysninger fra Vestlandet. Når det gjaldt vedlikeholdet av gravene, beklaget man fra departementets side at dette ikke var tilfredsstillende utført ved gravene i Nord-Norge. Årsaken til dette skyldtes store avstander, vanskelige kommunikasjonsforbindelser og at gravene store deler av året var vanskelig tilgjengelig. Interessen for arbeidet med gravene var stor, og man mente at dette arbeidet ville bli vesentlig lettere hvis gravene ble samlet på færre kirkegårder. For de øvrige landsdelenes vedkommende var arbeidet med vedlikeholdet godt i gang, og gravene var stort sett i god stand. På flere gravsteder var det også blitt reist nye minnesmerker. Flere flyttinger av graver var dessuten gjennomført over hele landet. Etter anmodning fra Norsk-Sovjetrussisk Samband i Stavanger var 90 sovjetiske krigsgraver flyttet fra Skadberg til Eiganes kommunale kirkegård i Stavanger, hvor sambandet lenge hadde ønsket å reise et minnesmerke. Året før, på høsten i 1949 ble 240 sovjetiske krigsgraver flyttet fra Tårnet i Sør-Varanger til Høybuktmoen vest for Kirkenes. Flyttingen her ble gjennomført fordi den tidligere assisterende militærattaché ved den sovjetiske ambassaden, oberstløytnant V.S. Prokhorow, overfor de lokale myndighetene hadde gitt uttrykk for at disse ofrene ikke var forsvarlig gravlagt. Samtidig ble 17 sovjetiske krigsgraver, som lå spredt rundt i Kistrand herred i Finnmark, 
flyttet til den store Klubben kirkegård i Billefjord ved Porsangerfjord. ${ }^{221}$ Under flyttingen ble tre av likene identifisert. De tre hadde mistet livet i Nedrevatn i Porsangmoen. Navnene på de tre var:

Kgf. Shunwelj N-II.D. 87694

Kgf. Saporoshez 87972

Karatschenko N-II.D. 87195

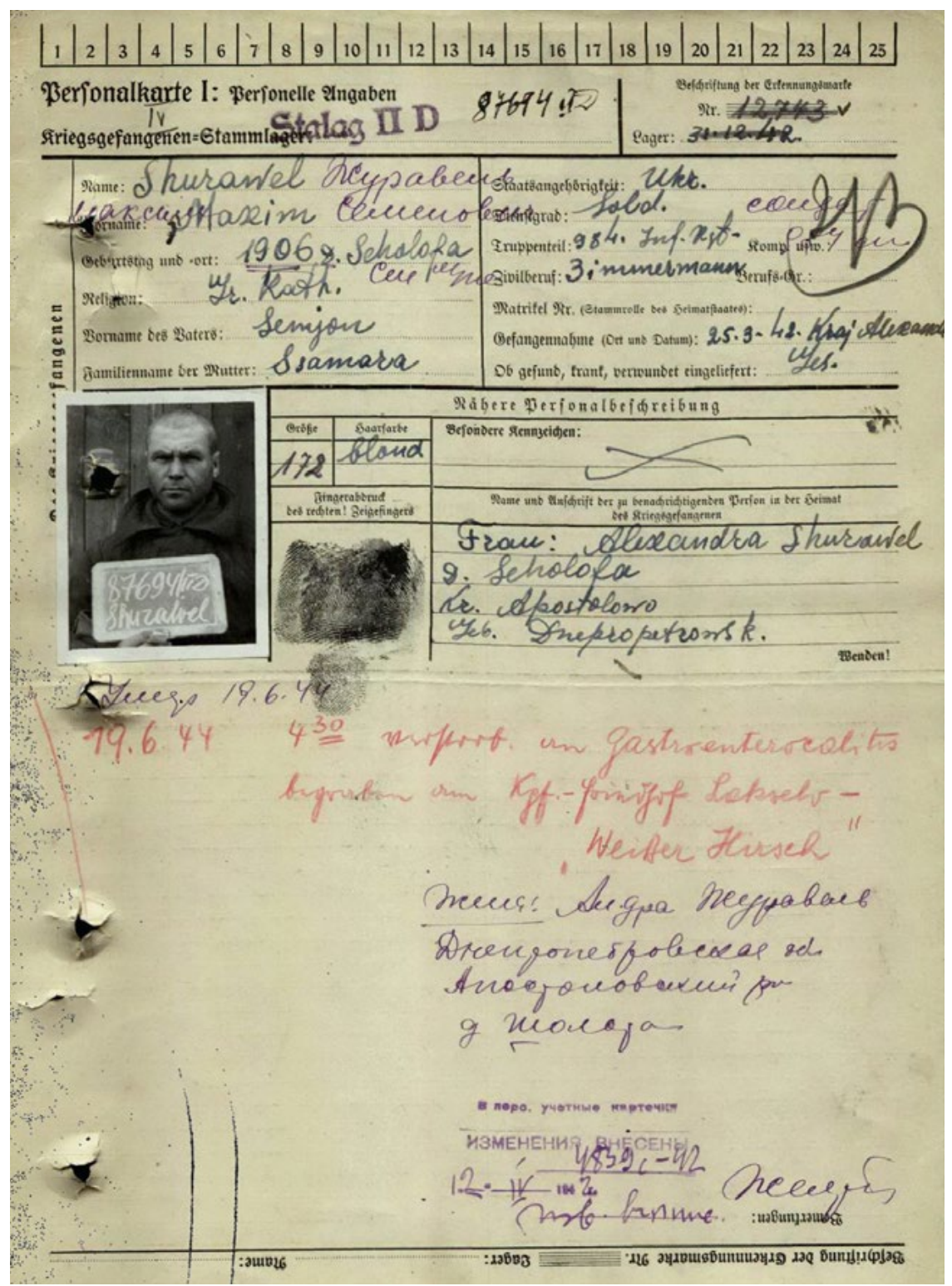

Fangekort fra Porsangmoen. Krigsfange Shunwelj N-II.D. 87694. Foto: www.obd-memorial.ru.

221 RA, Krigsgravtjenesten, eske 26-35. Vedlegg. Utenriksdepartementet. Oslo 09.05.1951. 


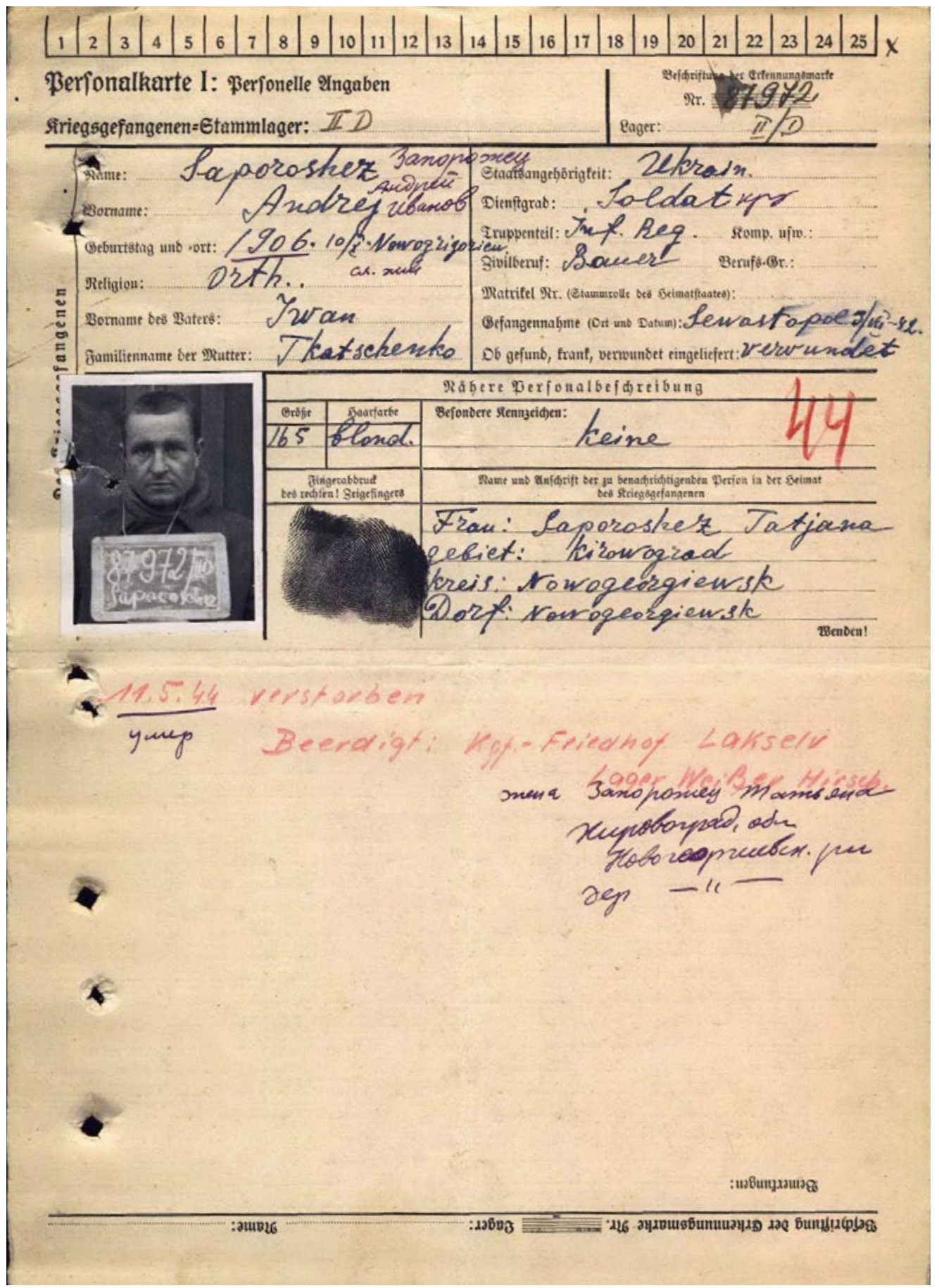

Fangekort fra Porsangmoen. Krigsfange Saporoshez 87972. Foto: www.obd-memorial.ru. 


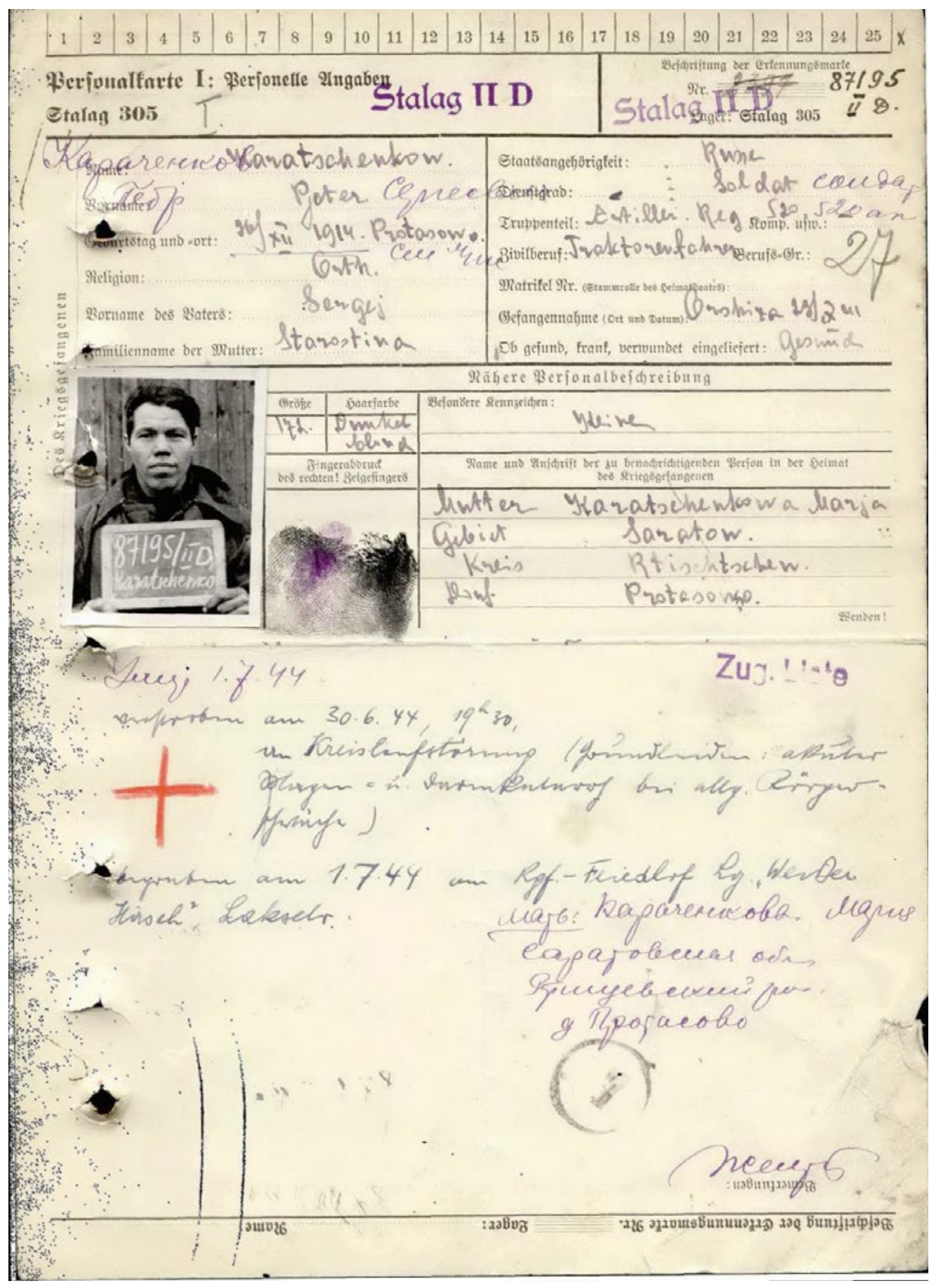

Fangekort fra Porsangmoen. Krigsfange Karatschenko N-II.D. 87195. Foto: www.obd-memorial.ru. 
Byråsjef Kornelius Halsne ved Sentralkontoret for krigsgraver fikk den 6. juli 1951 i oppdrag å gjennomføre «Operasjon asfalt» innen utgangen av oktober 1951. På dette tidspunktet forelå det ikke mer opplysninger om valg av sted til krigskirkegård enn at Forsvarsstaben hadde oppgitt at kirkegården i Nord-Norge burde ligge i Vefsn-området. Kirkedepartementet hadde påpekt at det fantes muligheter for å skaffe eiendom til formålet i Hemnes kommune, men opplyste også at man burde undersøke mulighetene for å finne grunn på privat eiendom. Dette alternativet var ikke aktuelt siden det ikke var tid nok til å forhandle om frivillig salg eller gjennomføre ekspropriasjonssak. Halsne mente derfor at det var heldig at en grunn som tilfredsstilte kravene til kirkegård var skaffet på statens eiendom ved statens sauealsgård i Tjøtta. Stedet ble også godkjent av Forsvarsstaben, Utenriksdepartementet, Landbruksdepartementet og Forsvarsdepartementet. ${ }^{222}$

Kirkedepartementet ville ikke godkjenne stedet som var valgt før de hadde skaffet nærmere opplysninger og uttalelser fra prestegårdstilsyn, bygningsråd og kommunale myndigheter. Departementet påpekte at det forelå reguleringsplaner for bymessig bebyggelse ved prestegårdene både i Vefsn og Hemnes. Det ble også vist til at et større industrianlegg var under planlegging for Vefsn prestegård. En slik utbygging ville medføre at store deler av Vefsn prestegårds arealer måtte disponeres til byggetomter. De foreslo derfor å undersøke hvorvidt det var brukbare utmarksarealer tilhørende Saltdal prestegård som kunne brukes til kirkegård. ${ }^{223}$ Innvendingene fra Kirkedepartementet ble ikke avgjørende, og Tjøtta ble likevel valgt som sted for kirkegården.

Under gjennomføringen av «Operasjon asfalt» hadde Forsvarsdepartementet ansvaret for å be Kirkedepartementet og Sosialdepartementet om å informere lokale kirke- og helsemyndigheter om arbeidet som skulle gjennomføres. Kirkedepartementet sendte ikke denne informasjonen videre til lokale kirkemyndigheter før 6. september. Forsvarsdepartementet hadde imidlertid satt sine tjenestemenn i gang med arbeidet allerede i begynnelsen av august, i troen på at de lokale myndighetene var informert om arbeidet. Denne svikten skapte en rekke misforståelser under flyttingen. For at gjennomføringen av flyttingen skulle vekke minst mulig oppsikt, hadde tjenestemennene pålegg om ikke å omtale det planlagte arbeidet på forhånd. Erfaringene viste likevel senere at det ville vært bedre om man på forhånd hadde satt seg i direkte forbindelse med lokale myndigheter, som prester og lensmenn, og i en viss utstrekning kommunale myndigheter. For å lette på det senere arbeidet ble det sendt ut et direktiv om dette fra Forsvarsdepartementet. 224

222 RA, Krigsgravtjenesten, eske 26-35. Notat. «Ervervelse av tomt til krigskirkegård på Tjötta». 06.10.1951.

223 RA, Krigsgravtjenesten, eske 26-35. «Sammendragning av krigsgraver». Oslo, 12.07.1951.

${ }^{224}$ RA, Krigsgravtjenesten, eske 26-35. Notat. «Forsvarsdepartementets forberedelse og ledelse av gjennomføringen av operasjon asfalt». Oslo 22.10.1951. 


\subsection{Grensesoldat Ingolf Åkvik}

Ingolf Åkvik fra Smøla avtjente militærtjeneste i 1950 ved russergrensen ved Høybuktmoen i Finnmark. En dag ble han og medsoldatene spurt om å gjøre en svært uvanlig jobb, og jobben bestod i å grave opp sovjetiske lik. De fikk vite at ofrene var sovjetiske krigsfanger som hadde deltatt i byggingen av flyplassen på Høybuktmoen. Åkvik husker at det var mye skriverier i avisene om oppgravingen. Folk mente at likene ble gravd opp med gravemaskin, men han forteller at dette var ikke tilfelle. Gravemaskinen ble brukt på det øverste laget og deretter ble soldatene satt til å grave seg ned til ofrene. Det ble veldig fint gjort, forteller han. Det var et fint gravsted, og ingen fra lokalbefolkningen protesterte mot oppgravingen. Gravstedet lå langt fra bebyggelsen i området. Eksperter kom og la ofrene i gummierte sekker og forsøkte å identifisere ofrene. Journalister hadde ikke adgang under arbeidet med oppgravingen.

De som ønsket å trekke seg, fikk beskjed om at de hadde anledning til dette. Det var veldig mange som ikke ønsket å delta i oppgravingen og trakk seg med en gang. «Vi slapp å ta i ofrene, men det var litt ekkelt mens vi holdt

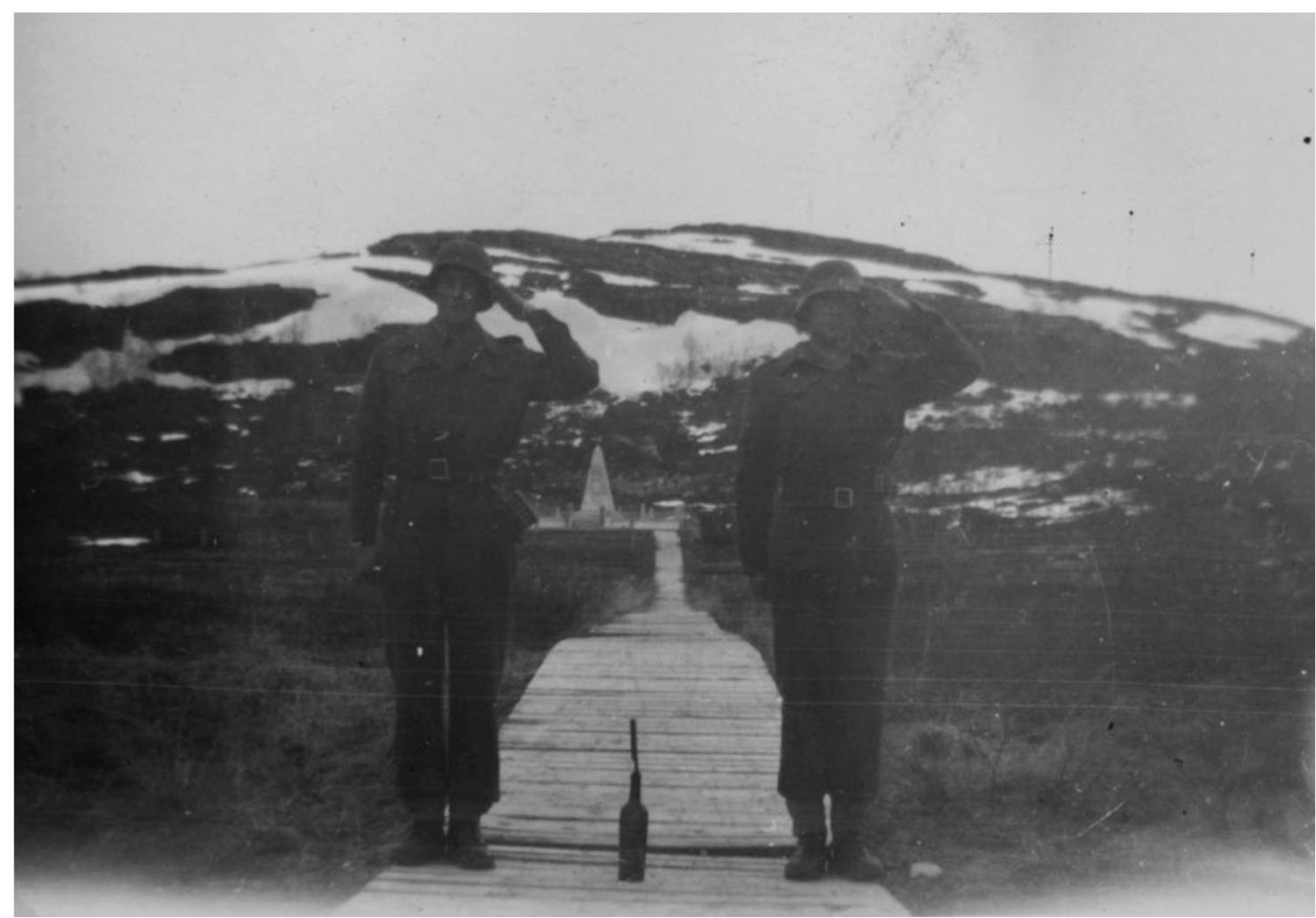

To norske soldater fra GSV 8 ved monumentet på Høybuktmoen 1950. Foto: Ingolf Åkvik. 
Det opprinnelige monumentet ved Høybuktmoen 1950. Foto: Ingolf Åkvik.

på med oppgravingen. Jeg trodde det skulle være mer lukt, men det gikk greit», forteller Ingolf Åkvik. Ofrene var lagt i rekker, og noen var bare stuet rett ned og lå i en haug. Ved oppgravingen kunne de se at noen av ofrene var blitt skutt på kanten av graven. Det ble funnet trekister ved oppgravingen som ofrene var lagt i. Ofrene var ikke gravlagt så dypt, de lå omtrent en meter fra der soldatene startet å grave. Åkvik forteller at de brukte en dag på å grave opp de sovjetiske ofrene på Høybuktmoen. Han husker ikke hvem som ledet arbeidet, men det var en feltprest til stede for dem som hadde behov for det. Det var folk som kom dit som hadde ansvaret for oppgravingen, men som ikke var militære. «Vi fikk ikke noe betaling for jobben fordi vi var i militæret», forteller Ingolf Åkvik. «Det var om lag 12-15 mann som fikk utdelt spade og ble med og grov opp ofrene.» ${ }^{225}$ Til tross for at oppdraget var en påkjenning for soldatene på grensevakt, følte Ingolf Åkvik at arbeidet var viktig, og at de var med på å sørge for at de sovjetiske ofrene fikk et ordentlig gravsted.

Sentralkontoret for krigsgraver, som var underlagt Hærens overkommando, mente at det ikke var hensiktsmessig å engasjere noe større lag av arbeidere som kunne reise rundt i Nord-Norge i forbindelse med oppgravingen. De var likevel nødt til å engasjere et større lag av arbeidere på de store krigskirkegårdene, som Skafferhullet og Høybuktmoen i Kirkenes. På Høybuktmoen ble derfor soldatene satt til dette arbeidet. Ved enkeltgraver og mindre ansamlin-

225 Intervju med Ingolf Åkvik i juli 2010. 
ger av graver skulle arbeidet utelukkende foregå med manuelle hjelpemidler. Ved større gravsteder kunne det bli aktuelt å benytte maskinelle hjelpemidler som for eksempel bulldoser. Men dette skulle kun foregå på de stedene hvor man visste at likene lå $\mathrm{i}$ en dybde som tilsa at de ikke ville bli skadet om bulldoser ble brukt til å fjerne det øverste jordlaget. Kremering av likene var ikke aktuelt, ifølge Sentralkontoret for krigsgraver. For å gjennomføre dette måtte det skaffes til veie transportable destruksjonsovner. Dette alternativet ble betraktet som svært vanskelig å gjennomføre i Nord-Norge. Ofrene hadde ligget gravlagt mellom seks og ti år før oppgravingen startet. Jordsmonnet der de var gravlagt, var svært varierende med steinjord, myr og leirjord. Tidsaspektet og jordsmonnet var avgjørende for likenes tilstand, og disse varierte i stor grad. Ved oppgravingen skulle likene bli lagt i sekslags papirposer hvor det innerste og ytterste laget ville være impregnert. Lignende poser var blitt brukt av amerikanerne under siste krig, og den norske kommisjonen for hjemføring av falne rapporterte at disse posene var i en meget god forfatning. På grunnlag av dette antok Sentralkontoret for krigsgraver at papirposene var den mest rasjonelle løsningen på emballasjeproblemet. Bruk av kasser eller kister til emballasje ville både fordyre og vanskeliggjøre arbeidet, og man mente det ville oppstå problemer med både anskaffelse og transport. Ved ordning av nytt gravfelt skulle likene legges i fellesgraver i dobbelt rekke med hodene mot hverandre. Arbeidet med klargjøring av fellesgravene måtte skje på samme tidspunkt som transporten av ofrene, og bulldoser skulle brukes til igjenfylling av gravene. Sentralkontoret for krigsgraver påpekte også at russerne tidligere hadde gitt uttrykk for at de ikke var interessert i merking av hver enkelt grav. Skulle dette likevel bli aktuelt, var det mulig å opprette rekker av steiner med fire plater med inngravert informasjon på hver side av steinene. ${ }^{226}$

Russerne reagerte kraftig på at det ble brukt gravemaskin under arbeidet med flyttingen av likene ved Høybuktmoen. Det sovjetiske telegrambyrået Tass meldte i oktober 1951 at alle sovjetiske krigsgraver i Kirkenes, Vardø og Vadsø ble i all hast ødelagt allerede i begynnelsen av august dette året. Tass rapporterte at de store massegravene på Høybuktmoen, Skafferhullet, Kiberg og Tana ble ødelagt samtidig. I mange tilfeller hadde man satt inn gravemaskiner for å påskynde ødeleggelsen av gravene. For å holde oppgravingen hemmelig for befolkningen ble arbeidet utført om natten. Monumentet på Høybuktmoen ble sprengt i stykker. Norsk lokalbefolkning og norsk presse hadde uttrykt sterk misnøye med myndighetenes fremgangsmåte, mente russerne. $^{227}$

226 RA, Krigsgravtjenesten, eske 26-35. «Arbeidets organisering». Hærens overkommando, Sentralkontoret for krigsgraver. Oslo. Udatert.

227 Friheten, 15.10.1951. 


\subsection{Planlegging av transport til Tjøtta krigs- kirkegård}

I tilknytning til transporten til Tjøtta ble sjøtransport, biltransport eller jernbanetransport diskutert. Krigsgravtjenesten diskuterte eventuell jernbanetransport av ofrene fra Sør-Norge til Tjøtta. På grunn av særlige takster for transport av lik ville fraktkostnadene bli svært høye. Trafikkdirektør Olav Holtmon i NSB hadde derfor gått med på å bruke de vanlige militærtakstene for frakt. Fra NSBs side ble det påpekt at transporten kom til å stride mot jernbanens vanlige regler for transport av lik. Forutsetningen for at NSB skulle gjennomføre oppdraget, var at helsemyndighetene ga sitt samtykke. NSB var opptatt av at det ikke var mulig å få en erklæring om at dødsårsaken ikke skyldtes smittsom sykdom, og det var heller ikke mulig å oppfylle kravet om at likene skulle legges i kister som tilfredsstilte bestemte krav. ${ }^{228}$ Overlege Jon Bjørnsson i Helsedirektoratet opplyste at de ikke ville ha noen innvendinger angående transporten av lik $i$ asfaltsekker med jernbane, bil eller fartøy på grunn av de særegne omstendighetene. Helsedirektoratet forberedte seg på å varsle samtlige helseråd $\mathrm{i}$ landet ved rundskriv konfidensielt til formennene for at lokale vanskeligheter ikke skulle oppstå. ${ }^{229} \mathrm{H}$ æren ble kontaktet i juli 1951 i forbindelse med transportspørsmålet. Oberst Knut Sverre Langslet opplyste derimot at de ikke kunne regne med at Hærens forsyningstropper kunne delta i flyttingen. Forsyningstroppene hadde altfor mange oppdrag og måtte først og fremst ta hensyn til de utdannelsesmessige kravene. ${ }^{230}$

I forbindelse med sjøtransporten ble kommandørkaptein Ole Siem konsultert. Det ble gjennomført en del undersøkelser, og det skulle vise seg at under alle omstendigheter ville sjøtransport være den mest økonomiske transportmåten i Nord-Norge. Det forelå flere alternativer for sjøtransport. Et av alternativene var å leie et rutefartøy. Skipet skulle sendes fra Kirkenes og sørover og samle opp asfaltsekkene på utvalgte samlesteder. Det ble fremhevet at et rutefartøy ville egne seg bra fordi det hadde flere dekk, slik at det ikke ville oppstå vanskeligheter med innlastingen av det «særegne gods». Et annet alternativ var å leie $\mathrm{D} / \mathrm{S}$ «Raftsund» av Vesteraalens Dampskibsselskap. For Nord-Norges vedkommende ville sjøtransport over de lange avstandene gi de laveste kostnadene. ${ }^{231}$

${ }^{228}$ RA, Krigsgravtjenesten, eske 26-35. Notat. «Jernbanetransport av russiske lik». Oslo 05.07.1951.

229 RA, Krigsgravtjenesten, eske 26-35. Notat. «Telefonsamtale med Helsedirektoratet». 05.07.1951.

230 RA, Krigsgravtjenesten, eske 26-35. Notat. «Telefonsamtale med sjefen for Hærens forsyningstropper». 05.07.1951.

231 RA, RAFA-2018/D/Da/L0026. «Forsvarsdepartementets plan for istandsetting og vedlikehold av de russiske krigsgraver». Oslo 26.06.1951. 
Kommandørkaptein Siem stilte spørsmål til hvorvidt skipsselskapene ville leie bort fartøyer til dette formålet. Han mente det var flere grunner til at selskapene ikke ønsket at skipene skulle brukes til denne oppgaven. Blant annet fryktet man at den nordnorske befolkningen ville reagere på at skipsrom som egentlig ble brukt til frakt av matvarer, skulle benyttes til en så uhyggelig last. Besetning som ikke var forhyrt for denne typen transport, kunne nekte å være med skipet, og derfor måtte man undersøke muligheten til å bruke andre skip. Lasten måtte behandles med varsomhet og ærbødighet, så derfor ville det neppe være mulig å bruke en alminnelig lastebåt, mente Siem. Det var nødvendig med et skip med flere dekk som lasten kunne stables på. Siem påpekte også at det kunne oppstå vanskeligheter ved innlastingen, idet transportarbeiderne ved kaiene hadde rett til å laste skipene. Det måtte da bli forklart hva slags transport dette var. Men ettersom dette måtte foregå så hemmelig som mulig, ville en forklaring til transportarbeiderne medføre en offentliggjøring. Innlastingen burde derfor ikke foregå ved offentlig kai, men helst fra en båt ute på sjøen. Samlet kostnadsoverslag for leie av D/S «Raftsund» til oppdraget og kostnader til samleskøyter og ekstra biler ble satt til $82000 \mathrm{kr}^{232}$ Det viste seg etter hvert at for Nord-Norge var sjøtransport med større skip det mest økonomiske transportalternativet. D/S «Raftsund» lå på dette tidspunktet i opplag, og det var en fordel at man kunne disponere skipet uavhengig av avtalt befraktningstid. ${ }^{233}$

Siem kontaktet direktøren for Vesteraalens Dampskibsselskap, Chr. Stockinger jr., og beskrev oppdraget. Han var særlig opptatt av regjeringens ønske om at transporten av likene skulle bli utført på en verdig og ordentlig måte. Siem påpekte at saken hadde adskillige vanskelige sider som krevde stor nøyaktighet, og saken måtte behandles med den største diskresjon i alle ledd, og i all hemmelighet. Den norske regjeringen ønsket gjennom Forsvarsdepartementet å skaffe et tilbud på transport av 8060 lik som lå begravd spredt over hele Nord-Norge. For enkelthets skyld ønsket regjeringen bare å ha med transporten å gjøre og ikke oppgravingen og transport til samlestedene, og de mente det var naturlig at et dampskipsselskap fikk ansvaret for hovedtransporten. Sentralkontoret for krigsgraver hadde ansvaret for de oppgavene regjeringen ikke ønsket å påta seg. Saken ble nøye diskutert sentralt og mange muligheter ble antydet og undersøkt. Blant annet diskuterte man brenning og transport av asken. Til slutt var det enighet om transport av likene i vanntette sekker. Sekkene var impregnert med et asfaltstoff som antakelig ville sette lukt i skipet. Det måtte derfor regnes med en grundig rengjøring av skipet etter endt oppdrag.

232 RA, RAFA-2018/D/Da/L0026. Notat. 05.07.1951.

233 RA, RAFA-2018/D/Da/L0026. «Forsvarsdepartementets plan for istandsetting og vedlikehold av de russiske krigsgraver». Oslo 26.06.1951. 
Etter å ha diskutert mulighetene for transport av likene med godsskip i ordinær rute var det enighet om å leie $\mathrm{D} / \mathrm{S}$ «Raftsund» til oppdraget. Egne skøyter skulle brukes for å hente likene slik at de kunne omlastes på egnet sted. Siem var også opptatt av at lasting og lossing burde foregå med eget mannskap om bord i skipet. Innlastingen skulle foregå på reden, fra båt, for å unngå publisitet om saken. Han opplyste at hvert lik veide ca. $35 \mathrm{~kg}$ og foreløpig hadde han bare informasjon om at lasten skulle losses i Vefsn. Det var viktig at likene ble sortert slik at de navngitte ble plassert for seg, og alle måtte merkes nøyaktig. Æresbevisninger og høytideligheter ved den siste delen av transporten skulle ordnes av russerne, og eventuelt av vedkommende kommune. Forsvarsdepartementet måtte til enhver tid vite skipets posisjon under transporten. Saken hastet, og Siem ønsket snarest et svar på om selskapet tok på seg oppdraget. ${ }^{234}$ Selskapet påtok seg oppdraget, og to av skipene deres ble satt inn i transporten.

Det andre skipet som ble satt inn i transporten til Tjøtta, var D/S «Tanahorn». Både «Raftsund» og "Tanahorn» var befraktet gjennom Vesteraalens Dampskibsselskap på Stokmarknes. Kapteinen på «Tanahorn» fikk strenge instrukser før reisen. På grunn av transportens spesielle art og særegne forhold knyttet til den var det nødvendig at den ble gjennomført uten uhell. Kapteinen ble bedt om å være ytterst påpasselig på reisen nordover og særlig etter at det var tatt inn last om bord. Det måtte ikke tas noe unødig risiko. Etter at lasten var på plass, skulle skipet kun seile i godvær. I tilfelle av dårlig vær eller dårlig sikt ble kapteinen bedt om å ta det med ro, siden tiden for transporten spilte mindre rolle enn at lasten kom trygt frem. ${ }^{235}$

Forsvarsdepartementet var åpenbart nervøse for gjennomføringen av transporten, og ga skipsførerne svært strenge instrukser. Reisen skulle utføres etter en seilingsliste som var godkjent av departementet. Ved innlasting og utlossing skulle det vises den ytterste forsiktighet så vel med skip som med last. Ved anløpsstedene skulle mannskapet være særlig forsiktige med fortøyning og ankring. Hvis innlastingsstedet lå utsatt til og det var dårlig vær, måtte skipet flyttes til en sikker ankerplass i nærheten og innlastingen utsettes inntil den kunne fortsette uten risiko for skip eller last. Skipet måtte ikke forlate en sikker ankerplass uten at værforholdene var så gode at reisen kunne foregå uten risiko. Under hele reisen måtte det utvises den ytterste forsiktighet med ild eller lys, for å unngå all fare for brann. Alle som var om bord i skipene, skulle opptre rolig og sømmelig, og det måtte ikke forekomme hendelser av noen art som kunne påkalle uheldig offentlig oppmerksomhet.

234 RA, Krigsgravtjenesten, eske 26-35. Gjenpart av korrespondanse. Oslo 05.07.1951.

235 RA, Krigsgravtjenesten, eske 26-35. «Herr kapteinen d/s 'Tanahorn'», Vardø. 04.10.1951. 
Skjenning, munnhuggeri, fyll, slagsmål, høyrøstet snakk og latter var ikke tillatt. Besetningen fikk heller ikke landlov under reisen. Ifølge instruksen skulle skipets kaptein under hele reisen rådføre seg med Forsvarsdepartementets representanter om bord. ${ }^{236}$

Forsvarsdepartementet mente det ville være en betryggelse om et marinefartøy ledsaget de to skipene under reisen fra Kirkenes til utlastingsstedet Søvik på Alstenøy i Nordland. Dermed ble det bestemt at KNM «Andenes» skulle fungere som følgebåt under oppdraget. Departementet påpekte at gjennomføringen av konvoien burde skje i mest mulig diskré former. Sjefen om bord på marinefartøyet kunne orientere offiserene om oppdraget, men måtte sørge for at det ble snakket minst mulig om saken. KNM «Andenes» skulle gi inntrykk av at de var på tråleroppsyn og skulle ikke gå inn til de stedene hvor de gravlagte ble hentet, men holde seg diskré i nærheten. Kaptein Syvertsen var pålagt å kontakte Forsvarsdepartementet daglig for å innmelde skipenes posisjon og gi informasjon om eventuelle vanskeligheter. ${ }^{237}$ På samme tid ga Sjøforsvarets overkommando ordre om at kommandoen i Nord-Norge skulle drive sin oppsynstjeneste i nærheten av transportskipene, slik at nødvendig assistanse i havn eller på sjøen kunne bli gitt med minst mulig tidstap. Det ble fremhevet fra overkommandoens side at marinefartøyets operasjoner burde foregå mest mulig ubemerket. ${ }^{238}$ Sjøforsvarets kommando i NordNorge sendte operasjonsordren til KNM «Andenes» i begynnelsen av oktober 1951. Sjefen på marinefartøyet skulle etter ordren avtale med kapteinen på $\mathrm{D} / \mathrm{S}$ «Tanahorn» om samband og frekvenser. Hvis de to fartøyene hadde behov for assistanse fra marinefartøyet, skulle det rekvireres ved meldingen "her er trålere». Assistanse skulle kun gis etter anmodning fra og i samarbeid med politiet. Hvis det ble nødvendig å bruke skytevåpen, skulle det først skytes skremmeskudd i luften. Det er tydelig at Forsvarsdepartementet og Sjøforsvaret ønsket å unngå oppmerksomhet rundt oppdraget og forberedte seg på at det kunne oppstå vanskeligheter underveis. ${ }^{239}$ Tillatelsen til å bruke skytevåpen om nødvendig viser at militære myndigheter antok at det kunne oppstå alvorlige problemer under transporten til Tjøtta.

236 RA, Krigsgravtjenesten, eske 26-35. «Instruks. Til föreren av D/S 'Raftsund', gjeldende for reise Kirkenes-Tjötta inneværende höst under flytting av de russiske graver». 20.09.1951, Jnr. 1051/51.

${ }_{237}$ RA, Krigsgravtjenesten, eske 26-35. Notat, Det kongelige Forsvarsdepartement. Oslo 04.10.1951.

${ }^{238}$ RA, Krigsgravtjenesten, eske 26-35. «Transport av russiske lik». Sjøforsvarets overkommando. 04.10.1951.

239 RA, Krigsgravtjenesten, eske 26-35. «Operasjonsordre for 'Asfalt'». Sjøforsvarskommando Nord-Norge. Til K.N.M «Andenes». 08.10.1951. 


\subsection{Oppgraving, innlasting og transport}

Kaptein Arntzen ved Sentralkontoret for krigsgraver hadde ansvaret for oppgraving og transport av asfaltsekkene til de avtalte oppsamlingsstedene. Han hadde også ansvaret for å leie inn all nødvendig arbeidshjelp på gravstedene, og han hadde fullmakt til å gi all arbeidshjelp den betalingen som var nødvendig og tilstrekkelig. Arntzen hadde ansvaret for å føre protokoll over oppgraving og pakking og merking av sekkene. Herunder skulle det særlig tas hensyn til at navngitte ofre måtte holdes for seg. Arbeidet skulle gjennomføres på en verdig måte, og unødig oppsikt måtte unngås. Kapteinen skulle som nevnt starte i Kirkenes og derfra besøke samtlige gravsteder i Nord-Norge og laste på de avtalte oppsamlingsstedene. I instruksene ble det også påpekt at monumenter som arbeidet tillot å bli stående, ikke skulle røres. Etter oppgravingen skulle gravene gjenkastes og settes i rimelig ryddig stand. ${ }^{240}$ Denne instruksen omfattet krigskirkegårder. På ordinære kirkegårder var det de stedlige kirkegårdsmyndighetenes krav som gjaldt angående istandsettelse av gravplassen. For å unngå problemer av økonomisk art som kunne stoppe arbeidet med «Operasjon asfalt», ble det gitt egne direktiver. Avdeling II i Forsvarsstaben hadde ansvaret for de økonomiske spørsmålene i gjennomføringen av operasjonen, og måtte til enhver tid vite hvordan de kunne komme i kontakt med kaptein Arntzen. ${ }^{241}$

Forsvarsdepartementet ga i tilknytning til «Operasjon asfalt» klarsignal om å fjerne gravmonumenter hvis disse var til hinder for at levningene kunne flyttes. Det ble overlatt til den enkelte feltledelsen å ta denne avgjørelsen. Fra kaptein Arntzens side ble det generelt argumentert med at dynamitt var nødvendig hvis monumentene enten var i veien for gravingen eller i dårlig forfatning. ${ }^{242}$ Kaptein Syvertsen fra Krigsgravtjenesten var med D/S «Tanahorn» og deltok i arbeidet med oppgravingen i Lebesby i Finnmark. I en telefonsamtale med statssekretæren den 10. oktober 1951 fortalte Syvertsen at en gravplass med 26 gravlagte i Lebesby ikke var tatt opp. Et to meter høyt monument som hvilte på et betongfundament, dekket gravplassen, og det var ikke mulig å foreta oppgravingen uten å fjerne monumentet. Kapteinen hadde en arbeidsstyrke klar til å fjerne monumentet, men ba om forholdsordre. Årsaken til dette var at befolkningen var uvillig innstilt til en oppgraving. På grunn av rapporten fra Syvertsen sendte statssekretæren telegram via overvåkingspolitiet til Syvertsen og politimesteren i Sør-Varanger. Meldingen var at arbeidet i

240 RA, Krigsgravtjenesten, eske 26-35. «Sammendragning av de russiske krigsgraver. Operasjon Asfalt. Instruks for kontaktmann i Nord-Norge». Oslo 23.07.1951.

241 RA, Krigsgravtjenesten, eske 26-35. Notat, Forsvarsstaben avdeling II. Oslo 11.09.1951.

242 Eidsaune, Thor Helge: «Kirkegårdskrigen», i Årbok for Rana. Mo i Rana 1999: 14. 
Lebesby foreløpig måtte utsettes. ${ }^{243}$ Dagen etter mottok Syvertsen et telegram fra statssekretæren merket strengt hemmelig. I telegrammet ble det oppgitt at «Operasjon asfalt» skulle gjennomføres om mulig i Lebesby. Kapteinen ble oppfordret til å gi streng instruks om at monumentet skulle flyttes og oppbevares om nødvendig. Offentlige tjenestemenn, helst lensmenn, skulle overvåke oppgravingen. Dersom oppgravingen ble gjennomført, måtte kapteinen forsikre seg om at de oppgravde ofrene ble sendt med skipet D/S «Tanahorn». ${ }^{244}$ Som vi skal se senere, ble ødeleggelsene av monumentene en sentral del av lokalbefolkningens reaksjon på oppgravingene. Ifølge skipsdagboken ble det ikke rapportert om problemer ved innlastingen i Lebesby, men skipet ble liggende i ett døgn ekstra før avreise til Kjøllefjord. ${ }^{245}$

Etterretningsoffiseren ved Sjøforsvarskommando Nord-Norge ankom Kirkenes i begynnelsen av oktober 1951 for å delta på transporten sørover. Politimesteren i Sør-Varanger stilte med politistyrker i beredskap i tilfelle demonstrasjoner og uroligheter, og det ble satt ut vakt på kaia. Med politimesterens bistand fikk de også kontakt med direktør Hans Adler Torgersrud ved A/S Sydvaranger, som velvillig stilte med kai innenfor selskapets porter til disposisjon under innlastingen. Etterretningsavdelingen ved Sjøforsvarskommando Nord-Norge opplyste at Kirkenes var et av de stedene man måtte vente opptøyer under innlastingen. D/S «Tanahorn» ankom Kirkenes og innlasting av likene ble gjennomført av soldater ved garnison Sør-Varanger. Ved innlastingen av D/S «Tanahorn» i Kirkenes opplyste politiet at man merket en viss aktivitet fra kommunistene i form av små grupper som stod sammen og diskuterte. Politiet registrerte også at kommunistene var svært opptatt av å få vite tidspunktet for innlastingen av levningene og hvem de ansvarlige var. Det eneste man hadde lagt merke til, var to kjente kommunister i kaiområdet, som sannsynligvis kontrollerte tidspunktet for innlastingen. Det var ingen tegn til ansamlinger eller demonstrasjoner i byen, og politiet regnet med at eventuelle demonstrasjoner måtte improviseres. Innlastingen ble startet $\mathrm{kl}$. 15.00, og en halv time senere kom seks kommunister til kaia for å se på. Like før lastingen var ferdig, tok en av kommunistene et bilde av det som foregikk. Dette medførte en krangel med kaptein Arntzen. Kommunisten nektet å legitimere seg overfor kapteinen, som da var sivil, men legitimerte seg overfor politiet. Politiet ønsket ikke å gjøre mer med saken. Alt forløp stille og rolig. Senere hadde en av kommunistene fortalt at de hadde hatt til hensikt å lage

${ }^{243}$ RA, Krigsgravtjenesten, eske 26-35. Notat. "Operasjon Asfalt». Telefonsamtale med kaptein Syvertsen 10.10.1951. Statssekretæren.

${ }^{244}$ RA, Krigsgravtjenesten, eske 26-35. Telegram fra statssekretæren til kaptein Syvertsen. Oslo 11.10.1951.

245 RA, Krigsgravtjenesten, eske 26-35. Utdrag av D/S «Tanahorn»s dagbok. Oslo 24.11.1951. 
en tilstelning med blomsterportal og en kort tale som avskjedshilsen til de sovjetiske soldatene som falt i Sør-Varanger, men dette hadde ikke lyktes siden de ikke kjente tidspunktet for innlastingen. ${ }^{246}$

På neste innlastingssted, som var Vadsø, hadde ingen uvedkommende vært til stede under innlastingen av likene fra Kiberg og Vadsø. Neste lasteplass var Berlevåg. Likene var ikke gravd opp, men arbeidet ble gjennomført ved hjelp av lensmannen samme dag skipet ankom Berlevåg. Skipet ble deretter liggende i Lebesby fordi det var søndag - man mente det var usømmelig å begynne oppgravingen på en søndag. Dagen etter ble likene i Lebesby gravd opp, og i Sjøforsvarets rapport er det skrevet at hele dagen gikk med fordi likene måtte brennes før de ble brakt om bord. Dette ble senere avkreftet av Forsvarsdepartementet. Lensmannen i Alta opplyste at oppgravingen av de sovjetiske ofrene var gjennomført allerede i august 1951. Arbeidet hadde foregått uten demonstrasjoner, og han mente at det neppe ville bli noe bråk eller demonstrasjoner ved innlastingen. Ifølge lensmannen hadde trolig noen av stedets kommunister deltatt $i$ arbeidet med oppgravingen, og han mente at det ikke ville være nødvendig med assistanse fra Utrykningspolitiet ved innlastingen. I Alta ble innlastingen gjennomført om kvelden, og skipet ankret opp om natten for å unngå at noen øvde hærverk mot skipet. Lensmannen var om bord, og det dukket opp et par kommunister på kaia uten at noe skjedde. Etter ankomst Tromsø fortsatte D/S «Tanahorn» sørover, og etterretningsoffiseren kom om bord på D/S «Raftsund». Da skipet ankom Narvik, var ikke arbeidet med oppgravingen ferdig. Etterretningsoffiseren frarådet at skipet skulle vente i Narvik. Mannskapet på skipet var så "opprevne» at de ikke tålte å bli liggende og vente. Han påpekte at dersom det hadde kommet noen på kaia og slengt ukvemsord og hån til mannskapet, hadde de forsvunnet, alle sammen. Dessuten ville flere dagers ventetid ha kostet staten anslagsvis $10000 \mathrm{kr}$, og derfor fortsatte skipet videre til Røsvik. Innlastingen på de neste stedene gikk rolig for seg. I Mosjøen hadde kirketjeneren ansvaret for lasten på land. Han var meget nervøs og redd for ubehageligheter fra uvedkommende. Han ville ha lasten om bord med en gang skipet ankom Mosjøen, så innlastingen ble gjennomført om natten. Ingen uvedkommende dukket opp på kaia under innlastingen. ${ }^{247}$

I Kistrand hadde lensmannen fått overlevert egne instrukser for en diskré overvåking, og han fikk beskjed om å holde Krigsgravtjenesten informert om situasjonen fremover. Gravstedene innen dette distriktet var på Hatterfellet, Klubben ved Indre Billefjord og Luostejohka. Det ble imidlertid ikke funnet noen sovjetiske ofre på Hatterfellet under korsene som var oppsatt her. Det

246 RA, Krigsgravtjenesten, eske 26-35. «Notat fra politiet». Kirkenes 11.10.1951.

247 RA, Krigsgravtjenesten, eske 26-35. Rapport. «Operasjon asfalt». Tromsø 24.11.1951. 
ble antatt at årsaken til dette var at tyskerne hadde kastet likene i et vann like i nærheten. Lensmannen i Kistrand rapporterte i midten av oktober 1951 at innlastingen av likene ble gjennomført i Indre Billefjord, og at det hadde gått stille for seg. ${ }^{248}$

I løpet av sommeren 1951 var likene av tolv sovjetiske ofre gravd opp på kirkegården i Kiberg. Papirsekkene med ofrene ble lagret i en kullhaug på en brygge i Kiberg, hvor de ble liggende i flere måneder. Det gikk stadig folk ut på brygga - voksne og barn - enten av ren nysgjerrighet eller for å hente kull. Folk i Kiberg hadde særlig lagt merke til at arbeidet med oppgravingen ble gjennomført om natten. De syntes det var underlig at folk som var ute i lovlig ærend, ikke kunne arbeide om dagen. ${ }^{249}$ Papirsekker med sovjetiske ofre fra Tana ble også lagret på brygga i Kiberg. En større andel av de sovjetiske krigsfangene i Kiberg døde av skjørbuk i november og desember 1942. Sognepresten oppga navnene på seks av de døde. Navnene var hentet fra innskriftene på gravkorsene. Han hadde fått opplyst at andre døde som ble funnet i utmarken, skulle bli flyttet til en kirkegård ved hjelp av tyske krigsfanger kort tid etter frigjøringen. Politiet skulle sørge for at dette ble utført, men ingenting ble gjort. Sognepresten ba derfor Sentralkontoret for krigsgraver om bistand for å få gravd opp de døde i utmarken og flytte disse til kirkegården i Kiberg. På grunn av at han ventet på bistand, hadde han ikke fått besørget noen jordfestelse av de andre sovjetiske gravene i Kiberg. ${ }^{250}$

Befolkningen i Vadsø var ikke fornøyd med fremgangsmåten ved oppgraving og lagring av de sovjetiske ofrene i byen. Den 6. oktober 1951 trykte avisen Finnmarken artikkelen «Uansvarlig behandling av de russiske krigsofre i Finnmark». I artikkelen ble det hevdet at arbeidet med å samle de sovjetiske falne under krigen i en felleskirkegård ikke alltid foregikk sømmelig eller sunnhetsmessig forsvarlig. I lengre tid hadde oppgravde lik ligget i papirsekker i en dampskipsekspedisjon. Bårene ble ikke sendt videre med en gang, men flyttet til en transporthall ved et kjølelager. Her hadde levningene etter de sovjetiske ofrene blitt liggende i et par måneder, uten at de ansvarlige for oppgravingene i Finnmark hadde sørget for å sende bårene videre til felleskirkegården. I avisen ble det fremhevet at arbeidet med å flytte de sovjetiske gravene til en felles kirkegård ble gjennomført for at det skulle bli lettere å stelle gravene. Det hadde ingenting med skjending å gjøre, slik kommunis-

248 RA, Krigsgravtjenesten, eske 26-35. Notat. «Ad telegram 6/10-51 russergraver». Hammerfest 16.10.51.

249 Nordland Arbeiderblad, 02.10.1951.

250 RA, RAFA-2018/D/Da/L0024. "Utenlandske statsborgere, begravet i Norge under okkupasjonen 1940-45». Vardø 06.03.1947. 
tene hevdet i sin agitasjon. ${ }^{251}$ Folk i Vadsø var sinte over fremgangsmåten og arbeidet med flyttingen av ofrene. Forfatteren av artikkelen i avisen mente at de ansvarlige burde få en kraftig korreks og bli fratatt videre arbeid med oppgravingene.

Det var svært vanskelig å holde oversikt over antallet graver på de ulike stedene, og enkelte steder var ikke oppført på listen over krigsgraver. Lensmannen i Skjervøy opplyste at det ikke var foretatt oppgravinger i hans distrikt. Han fortalte at det var to graver i Skjervøy og 40 graver i Nordreisa. Gravene i Nordreisa var ikke registrert på listen over graver. Lensmannen ble bedt om å sørge for oppgravingen av ofrene i Nordreisa, men han lyktes ikke med å skaffe folk som ville påta seg dette arbeidet. Han var også bekymret for demonstrasjoner i Nordreisa dersom oppgravingen ble påbegynt der. ${ }^{252}$

Noen uker senere ble oppgravingen i Nordreisa likevel gjennomført, men det er ikke oppgitt hvem som påtok seg oppdraget. Mot slutten av oktober 1951 rapporterte kaptein Ove Bang Overdale til Forsvarsdepartementet fra oppgravingen i Finnmark og Troms i tilknytning til transport med D/S «Tanahorn». Oppgravinger i Karasjok var ikke gjennomført da det ikke var påvist sovjetiske graver der. I Troms var arbeidet avsluttet i Hatteng, Galgovatn, Kitdalen, Vang, Abaja, Lulle, Skibotn, Skjervøy, Nordreisa og Målselv. Likene var lastet om bord i D/S «Tanahorn». Under arbeidet i Nordreisa hadde en kvinne møtt opp på gravstedet og skjelt ut arbeiderne under oppgravingen. Neste morgen var planker med navneplater som stod på gravene, revet ned. Ved Storsteinnes, Takvatn, Breivikeidet, Skjold og Øvergård var arbeidet avsluttet og likene lastet om bord i D/S «Raftsund». Ved gravstedene på Nordstrøm, Bardufoss, Bardu og Setermoen var arbeidet ferdig og likene klar for lasting i Sjøvegan. Det samme gjaldt likene i Harstad, Trondenes, Kvæfjorden og Buvik, som ville bli lastet fra Harstad. Oppgravingen i Tromsø og Tromsdalen ville bli gjennomført så snart arbeiderne var klare. Oppgravingen i Holm i Dyrøy og Tranøy ble ledet av kaptein Arntzen. Årsaken til dette var at arbeideren som opprinnelig hadde ansvaret for oppgravingen på disse to stedene, var blitt kritisert i avisen Nordland Arbeiderblad. Han nektet å fortsette med oppgravingen og vurderte å anlegge sak mot avisen. Arntzen skulle treffe arbeideren på Setermoen i et forsøk på å få roet ham ned og fortsette arbeidet med oppgravingen. ${ }^{253}$

251 RA, Krigsgravtjenesten, eske 26-35. «Henvisning til bladet Finnmarken». 06.10.1951.

252 RA, Krigsgravtjenesten, eske 26-35. «Skriv mottatt fra Tromsö den 09.10.1951».

${ }^{253}$ RA, Krigsgravtjenesten, eske 26-35. «Skriv mottatt fra Tromsö den 22. 10.1951». 
Løytnant Snefjellå var med om bord på D/S «Tanahorn» på turen fra Finnmark. Underveis hadde han fått opplyst at det var blitt brent likrester, og at røyk fra brenningen var blitt observert av befolkningen. Brenningen hadde skjedd på gravsteder i Øst-Finnmark. Det ser ikke ut til at det kom noen reaksjoner fra Forsvaret angående brenningen. Fra Troms politidistrikt ble det opplyst at alt var rolig på gravstedene og stedene hvor det skulle gjennomføres utskipning av de døde. Men dette gjaldt ikke alle steder. Lensmannen i Skjervøy hadde problemer med oppgravingen der. En ting var den manglende arbeidshjelpen, men det var også problematisk at gravene nærmest lå i et myrhull. Hverken i Skjervøy eller Nordreisa var gravene tatt opp på dette tidspunktet. Lensmannen i Målselv hadde meldt at befolkningen hadde gitt uttrykk for at gravene på kirkegården burde ha fått ligge i fred. I Senja opplyste politiet at oppgravingen hadde foregått i sømmelige former. Det var ikke registrert noen form for reaksjoner på flyttingen av gravene blant befolkningen, og det var ikke demonstrasjoner mot arbeidet med oppgravingen. Forsvaret viste til at de eneste protestene mot oppgravingsarbeidet på Senja hadde kommet fra kommunistpressen. Senja politikammer rapporterte også at sovjetiske journalister hadde vært på besøk på Trondenes, men de hadde ikke noe å bemerke angående gravene. Lensmannen i Balsfjord rapporterte at det ikke var gjennomført oppgraving flere steder i hans distrikt. Dette gjaldt gravene i Sagelv, Takvatn og Øverbygd. ${ }^{254}$ I en intern melding til statssekretæren fra 4. kontor i Forsvarsdepartementet ble det avkreftet at det skulle ha blitt gjennomført brenning av lik. Kaptein Syvertsen hadde fulgt med på oppgravingsarbeidet og kunne fortelle at det var halvråtne kister og klesfiller som ble brent, og ikke likene. ${ }^{255}$

Kort tid etter rapporterte Overdale til Forsvarsdepartementet om situasjonen ved oppgravingene i Nordland. I Beisfjord var oppgravingen ferdig, og likene var sendt til Bjerkvik. I det som ble kalt Beisfjord II, var det tatt opp 20 lik som lå på kirkegården, og 13 lik var gravd opp i Narvik og plassert i kapellet. Arbeidet i Lødingen var ferdig, og sekkene var klare for utskipning. I Engeløy (Engelsøyvåg) var ca. 250 lik gravd opp og foreløpig plassert på kirkegården. Dette var antakelig gjort på grunn av at lensmannen ikke kunne skaffe folk til å fortsette oppgravingen. Kaptein Arntzen planla derfor å reise til Engeløy for å få arbeidet fullført, og han tok sikte på å være ferdig til D/S «Raftsund» kunne anløpe i slutten av oktober. Arbeidet var ellers ferdig i Kroken, Vassmo, Kobbvatn, Bodin, Bodø, Rognan og Fauske. Ofrene fra disse stedene var samlet og klar for innlasting i Røsvik i Sørfold. Det samme

254 RA, Krigsgravtjenesten, eske 26-35. «Skriv mottatt fra Tromsö den 11.10.1951».

255 RA, Krigsgravtjenesten, eske 26-35. Intern melding til statssekretærenes kontor fra 4. kontor, Forsvarsdepartementet. «Asfalt». 10.12.1951. 
gjaldt en del av gravene ved Hestbrinken kirkegård i Saltdal. Oppgravingen var ikke påbegynt i Laukvik i Nordfold, Borge, Kjerringøy, Vold i Buksnes, Sør-Arnøy, Meløy, resten av Hestbrinken, Korgen, Sørvollen i Hattfjelldal, Vega og Brønnøysund. Ifølge planen ville Arntzen sette i gang og fullføre oppgravingene på disse stedene. Overdale mente at det var best ikke å bruke $\mathrm{D} / \mathrm{S}$ «Raftsund» på disse stedene, men heller leie ei skøyte. Arntzen antok at dette arbeidet kunne være ferdig i slutten av november. Ved gravstedene i Bolna, Botn, Brennhei, Nabbvollen og Mosjøen var arbeidet ferdig, og ofrene skulle etter planen lastes inn på skipet i Mosjøen. På dette tidspunktet ble det oppgitt at gravene i Mo i Rana ikke var gravd opp. ${ }^{256}$ Ved oppgravingen ble det opplyst i lastelistene at det var funnet færre graver enn det som var oppført i Krigsgravtjenestens register. I Kobbvatn ble det funnet 70 sovjetiske gravlagte, 362 i Kroken og på Ørvik kirkegård i Helland ble det funnet 125.257

Oppgravingen ble drøftet med de kommunale myndighetene i november 1951 i Mo i Rana, og det ble besluttet å gjennomføre arbeidet på samme måte som i Narvik. Etter planen skulle ordføreren, presten og en politifullmektig være til stede. Kaptein Overdale rapporterte at de kommunale myndighetene var kjent med verbalnoten fra sovjetisk side som var kommet samme morgen. De var likevel ivrige etter å få gjennomført oppgravingen etter planen. Overdale antok at det ville bli en del små demonstrasjoner, men ikke noe alvorlig. Etter planen skulle arbeidet med oppgravingen være ferdig 1. november kl. 14.00, og kistene ville bli fraktet fra Mo i Rana med båt. Samme dag sendte Overdale et telegram til Forsvarsdepartementet med beskjed om at oppgravingen ville bli gjennomført med mindre han fikk ordre om noe annet. Etter at forsvarsminister Jens Christian Hauge hadde drøftet hendelsene angående protestene mot flyttingen av gravene i Mo i Rana med statsminister Einar Gerhardsen og statssekretær Boyesen, forklarte han kaptein Overdale at Forsvarsdepartementet ikke ville gi kontraordrer. Årsaken var at arbeidet var kommet langt, og de kommunale myndighetene var innstilt på å gjennomføre operasjonen. Hauge la vekt på at oppgravingen ble gjennomført så raskt og pietetsfullt som mulig. Han understreket at Forsvarsdepartementet regnet med at det hele var ferdig innen et par dager. ${ }^{258}$ Kaptein Overdale fikk imidlertid større problemer enn antatt i Mo i Rana. Årsaken til at gravene i Mo i Rana ikke var blitt flyttet, er beskrevet senere i tilknytning til protestene mot operasjonen i Nord-Norge.

256 RA, Krigsgravtjenesten, eske 26-35. «Skriv mottatt fra Tromsö den 24.10.1951».

257 RA, RAFA-2018/D/Da/L0026. Lastelister. «Operasjon asfalt». Udatert.

258 RA, Krigsgravtjenesten, eske 26-35. «Gravsakens stilling torsdag 1. november 1951». Oslo 01.11.1951. 
Tor Steffensen var om bord på et tredje skip som ble brukt til transport under «Operasjon asfalt». Dette var skipet D/S «Hestmanden», som ble satt inn i arbeidet med frakt av likrester fra Finnmark til Tjøtta. Han forteller at han var med på å grave opp og frakte lik langs norskekysten:

Vi stappet likdeler opp i sekkene og det stakk bein, knokler og ribbbein opp over alt. Kroppsdelene tilhørte ofte ikke samme person, og det var tilfeldig hva som endte opp i de forskjellige sekkene. Likene var fulle av mark og stanken var helt jævlig. ${ }^{259}$

Steffensen forteller at han aldri glemte synet som møtte ham da han hjalp til med å grave opp de sovjetiske ofrene. Han ville aldri ha sagt ja hvis han hadde visst hva arbeidet gikk ut på. Mannskapet på $\mathrm{D} / \mathrm{S}$ «Hestmanden» fikk betalt to kroner per sekk, men etter at mannskapet gjorde opprør og nektet å jobbe, ble beløpet hevet til fem kroner. Det var mye penger den gangen, minnes Steffensen. Mannskapet skrev aldri destinasjoner eller posisjoner i maskindagboken, noe de ellers alltid gjorde. I tillegg fikk de aldri landlov underveis, og det var ikke lov til å le eller krangle om bord, forteller Steffensen.

For flere av sjømennene som deltok i transporten av likene til Tjøtta, ble tiden etterpå svært tung. Steffensen husker at en fra mannskapet fikk flere sekker med likdeler over seg da de revnet under lossing. Det var et forferdelig syn, og like etter mønstret han av. Han ble aldri den samme etter denne uhyggelige opplevelsen, erindrer Steffensen. ${ }^{260}$

Mannskapet på D/S «Raftsund» krevde et tillegg på $20 \mathrm{kr}$ per dag for ubehagelig arbeid. De ønsket at dette tillegget skulle gjelde fra innlastingen og til fartøyet var utlosset og utrøyket. Mannskapet ønsket også at krigsforsikringsreglene skulle gjøres gjeldende. Forsvarsminister Jens Christian Hauge forsikret mannskapet om at de ville få utbetalt tillegget, men at det ikke var aktuelt å bruke krigsforsikringsloven. Mannskapet ønsket krigsforsikring dersom noen skulle bli syke som følge av smitte. Dette ble avvist, men de ble forsikret om at Forsvarsdepartementet ville opptre rimelig og forståelsesfullt dersom noen skulle bli syke som følge av smitte. ${ }^{261}$

Ved Storsteinnes i Troms begynte innlastingen av oppgravde levninger etter sovjetiske fanger om ettermiddagen 18. oktober. Lasten lå klar i et skur på kaia. Lastingen ble utsatt fordi det lå en mistenkelig båt ved kaia, og arbeidet startet ikke før den hadde forlatt området. Levningene var pakket i enkle papirsekker som til dels var oppbløtt og noe skadet. To mann fra land arbeidet i lasterommet, og mannskapet arbeidet på dekket under innlastingen. Flagget

259 Dagbladet, 24.05.2010.

260 Ibid.

261 RA, Krigsgravtjenesten, eske 26-35. Notat. «Gravsakens stilling». Oslo 01.11.1951. 
var på halv stang på skipet mens arbeidet pågikk. Skipet seilte deretter fra Storsteinnes til Tromsø. På grunn av været ble skipet liggende i Tromsø et par dager. Dette resulterte i helsefarlige forhold om bord da det ble oppdaget at proviantrommet hadde en åpen forbindelse til rommet der likene var lagret. Skipsdagboken viser også hemmeligholdelsen av oppdraget og mannskapets krav om ekstra betaling:

1. og 2. styrmann sammen med stuerten undersøkte proviantrommet som ble funnet å ha åpen forbindelse med rom no. 2 hva gass angikk. Likeså ble aktre matros og fyrbøterlugarer undersøkt og disse har åpne spylgatt til rommet. Disse spylgatt ble sementert igjen. All proviant ble fjernet fra proviantrommet, unntatt hermetikken. I tunellen var det en merkbar liklukt som trengte inn fra rommet gjennom åpninger i tunellen. Lukene ble åpnet for lufting. Vaktene dreier. Vakt på broen. Skipet skal stå i radioforbindelse med marinefartøiet «Andenes» under dekknavn. Mannskapet har stillet krav om ekstrabetaling og krevd svar innen 25. d.m. ${ }^{262}$

Det som i dagboken beskrives som spylgatt, er spygatt, som er en åpning i skutesiden til avløp for vann på dekk. Disse ble altså sementert igjen for å unngå liklukt i skipets lugarer og proviantrom.

Da skipet lå i Tromsø, ble det igjen stilt krav fra mannskapet om mer betaling. I Harstad hadde kapteinen fătt svar fra rederiet om at mannskapet skulle få $20 \mathrm{kr}$ de dagene det ble losset eller lastet, og at offiserene skulle få dobbel hyre under samme forhold. Men mannskapet var etter hvert blitt så nervøse på grunn av den uhyggelige lasten, og var lite mottakelige for fornuft, ifølge kapteinen. Mannskapet hevdet overfor tillitsmannen fra Sjømannsforbundet at de var lurt til å være med på liktransporten, og derfor stolte de ikke på departementets løfte før det ble bekreftet fra en av deres egne. ${ }^{263}$ Løytnant Snefjellå i Sjøforsvarskommando Nord-Norge bekreftet med en erklæring den 2. november 1951 at Forsvarsdepartementet hadde mottatt kravet om tillegget. Mannskapet på D/S «Raftsund» skulle i den tiden de var i fart med sovjetiske lik fra steder i Nord-Norge til Søvik i Alstadhaug, ha $20 \mathrm{kr}$ per person per dag fra staten i tillegg til sin ordinære hyre. Tillegget gjaldt fra den dagen likene ble tatt om bord på første lasteplass til de var utlosset på bestemmelsesstedet. ${ }^{264}$

Skipsdagboken til D/S «Raftsund» vitner om fortsatt uenighet angående betalingen til mannskapene på grunn av det krevende oppdraget. Skipet fort-

${ }^{262}$ RA, Krigsgravtjenesten, eske 26-35. Dagbokutdrag for D/S Raftsund. 12.10-03.11.1951.

263 RA, Krigsgravtjenesten, eske 26-35. «Rapport om Operasjon 'Asfalt'». Tromsø

24.11.1951.

264 RA, Krigsgravtjenesten, eske 26-35. «Erklæring». Sandnessjøen 02.11.1951. 
satte sørover, og i Sjøvegan i Salangen ble det lastet 111 sekker med likrester om bord. Sekkene var for det meste åpne. Ved innlasting i Trondenes i Harstad ble 194 sekker lastet om bord. Også her var det mange sekker som var åpne. Det samme gjaldt sekkene som ble innlastet i Narvik. Mannskapet krevde ekstrabetaling av kapteinen og varslet den 26. oktober at alle mann ville forlate skipet i Bjerkvik i Narvik om deres krav ikke ble imøtekommet. Etter at kapteinen hadde fått roet ned mannskapet og var ferdig med meglingen om ekstrabetaling, sa en båtsmann opp. Fyrbøteren hadde sagt opp tidligere på dagen. Dagen etter ankom en tillitsmann fra Narvik og avgjorde diverse tvister. Mannskapet ble enige om det fremsatte forslaget til ekstrabetaling. Etter at det var oppnådd enighet om betalingen, ankom den første bilen med likrester, og innlastingen begynte straks. Til sammen 170 sekker ble lastet inn, og sekkene var til dels åpne. Ved Røsvik i Sørfold ble 299 sekker med knokler lastet om bord om kvelden søndag 28. oktober. En del av sekkene var vanlige papirsekker hvor noen var oppbløtt innenfra og ødelagt. Et par dager senere var skipet i Mosjøen. Mannskapet startet innlastingen av 244 sekker ved midnatt tirsdag 30. oktober og var ferdig etter tre timer. Litt senere fortsatte skipet videre til losseplassen på Søvik i Sandnessjøen. Fem mann på land deltok i lossingen av sekkene på Søvik. Under lossingen ble de ødelagte sekkene lagt i nye sekker. ${ }^{265}$

Oppgravingen av de sovjetiske ofrene i Narvik var gjennomført den 29. oktober og ble avsluttet med militær honnør og offisiell seremoni. Arbeidet med oppgravingen var gjennomført i samråd med ordfører, politimester, fungerende sogneprest, bygartner og Forsvaret i Narvik. Arbeidet i Beisfjord ble gjennomført de neste to dagene, og ble avsluttet med en enkel offisiell seremoni. Kistene fra Narvik og Beisfjord ble tatt om bord i marinefartøyet KNM «Ramsund» på grunn av vanskeligheter med mannskapet på D/S «Raftsund». Overdale kontaktet Norsk Sjømannsforbund i Narvik og garanterte mannskapene på D/S «Raftsund» 20 kroner per dag i tillegg til hyre også for dager hvor det ikke var arbeid med innlasting. ${ }^{266} \mathrm{KNM}$ «Ramsund» ble også brukt til å frakte to sovjetiske ofre fra kirkegården i Borge og et fra kirkegården på Vold i Buksnes i Lofoten. Oppgravingen på disse to stedene ble gjennomført den 2. november 1951. I forbindelse med oppgravingen her er det notert i merknadsfeltet til innlastingslistene at lensmennene på begge stedene protesterte mot oppgravingen. ${ }^{267}$

265 RA, Krigsgravtjenesten, eske 26-35. Dagbokutdrag for D/S «Raftsund». 12.1003.11.1951.

266 NHM, 278. Krigsgravtjenesten, dokumentsamling. «Rapport fra kaptein O. B. Overdale». Oslo 08.11.1951.

267 RA, Krigsgravtjenesten, eske 26-35. Innlastingslister. Operasjon «Asfalt». Udatert. 
Rengjøringen av rommene om bord der likene hadde vært lastet, var ikke helt ufarlig for mannskapet. Mannskapet kunne bare arbeide i kort tid på grunn av gassdannelse. Flere ble kvalme og hadde besvimelsesanfall. I Sandnessjøen ble distriktslegen kontaktet, og han forlangte stadig utlufting og spyling av rommene for å fjerne gassen. Likene hadde vært lastet i lasterommet bak på skipet. For å desinfisere rommene ble de satt under damp i et døgn og deretter spylt med klor, kaustisk soda og Fenol. På grunn av den sterke gassansamlingen tok det tre dager å få rommene grundig nok rengjort. Den 2. november 1951 var skipet utlosset og rengjøringen fullført. Samme dag ble skipet levert tilbake fra Forsvarsdepartementet til rederiet Vesteraalens Dampskibsselskap. Løytnant Snefjellå ved Forsvarsdepartementet tok ved overleveringen forbehold om eventuelle skader på skipet som følge av det særegne oppdraget det hadde vært brukt til. ${ }^{268}$ Skipsdagboken viser i aller høyeste grad det ubehagelige arbeidet som mannskapet og arbeidshjelpen på land ble utsatt for under både innlasting og utlossing av sekkene med levninger etter sovjetiske ofre.

Utdrag fra skipsdagboken til D/S «Tanahorn» i tiden 8.-29. oktober 1951 gir inntrykk av det spesielle oppdraget:

Avgikk fra Vadsø kl. 0600 og ankom til Kirkenes kl. 0845, fortøyet ved D/s kaia. KL. 1430 gikk man til A/S Sydvarangers kai og fortøyet. Kl. 1500 kom 3 biler med last. På grunn av lastens spesielle art blev den innlastet med stor varsomhet og alvor. Flagget blev senket på halv mast. Lasten blev innlastet under oppsyn av skipets kaptein, tilstede ellers var Kaptein Syvertsen, Kaptein Arntsen, Marineløytnant Snefjellå alle tre var utsendt fra Forsvarsdepartementet. Var ferdig kl. 1630. Skipet blir liggende ved kaia. Vakter gåes. Politivakt på kaia. ${ }^{269}$

Utdraget fra skipsdagboken var stemplet «hemmelig» og sendt fra Sjøforsvarets overkommando til Forsvarsdepartementet. Det ser også ut til at de fleste avgangene etter innlasting skjedde om natten. Dette ble sannsynligvis gjort for ikke å vekke oppmerksomhet blant befolkningen. I skipsdagboken ble det ikke rapportert om noen særlige problemer ved de ulike innlastingsstedene. Det eneste tilfellet som ble rapportert, var at skipet ble liggende og vente en dag i Berlevåg på grunn av at lasten ikke var klar. Om ettermiddagen ankom imidlertid en ekspedisjonsbåt med lasten, og turen kunne fortsette. I skipsdagboken til D/S «Tanahorn» er det generelt sett oppgitt svært få detaljer om

268 RA, Krigsgravtjenesten, eske 26-35. Dagbokutdrag for D/S «Raftsund». 12.1003.11.1951.

269 RA, Krigsgravtjenesten, eske 26-35. Utdrag av D/S «Tanahorn»s dagbok. Oslo 24.11.1951. 
skipets oppdrag under «Operasjon asfalt». Ved de ulike innlastingsstedene fra Vardø til Bodø skrev kapteinen som regel «fikk om bord sekkene» eller «fikk om bord de saker vi var for å hente» i skipsdagboken. Det ble heller ikke oppgitt hvor mange sekker som ble lastet på de ulike innlastingsstedene. Da skipet ankom Søvik i Sandnessjøen, ble lossingen gjennomført ved hjelp av folk på land. Lossingen tok to dager, og det ble satt opp vakt ved skipet. ${ }^{270}$ Med vakthold både om bord og på kaia var det tydelig at norske myndigheter ikke tok noen sjanser angående eventuelle reaksjoner eller negativ oppmerksomhet i forbindelse med transporten av de sovjetiske ofrene.

I slutten av november 1951 foreslo sjefen for Sjøforsvaret i Nord-Norge, kontreadmiral Bruun, en annen fremgangsmåte ved lignende operasjoner på et senere tidspunkt. Årsaken til dette var en rapport om «Operasjon asfalt» skrevet av etterretningsoffiser Snefjellå, der det ble vist til frykten for innblanding fra uvedkommende. Hvis lignende operasjoner skulle settes i gang senere, burde det overveies om ikke disse burde foretas i full offentlighet, mente Bruun. Arbeidet burde utføres om dagen, og når oppgravingen var fullført, foreslo han at en mindre militæravdeling burde delta i en seremoni som ble ledet av en prest, slik at de flyttede likene kunne ytes militær honnør. Hvis det var bebyggelse i gravplassenes nabolag, burde alle som hadde flaggstang, anmodes om å flagge på halv stang under seremonien og et eget program for en slik seremoni burde fastsettes. Bruun viste også til at det hadde vært skrevet mye i avisene i Nord-Norge om likflyttingen. Han mente det hadde kun blitt gitt uttrykk for meninger om ikke å flytte likene og om forstyrrelse av gravfreden. ${ }^{271}$

Forsvarsdepartementet innrømmet under gjennomføringen av «Operasjon asfalt» at det var vanskelig å finne egnede lagringssteder for de oppgravde ofrene. Gravkapeller som kunne brukes, fantes bare på de færreste stedene. Som lagerrom ble det brukt bunkerser, militære lagerrom, skipsbuer og annet. Dessverre kunne det ikke sies at alle disse stedene hadde vært tilfredsstillende. Det var også uheldig at lagringen strekte seg over mange uker for at man skulle kunne gjennomføre transporten i en vending. ${ }^{272}$

${ }^{270}$ RA, Krigsgravtjenesten, eske 26-35. Utdrag av D/S «Tanahorn»s dagbok. Oslo 24.11.1951.

271 RA, Krigsgravtjenesten, eske 26-35. «Rapport om Operasjon 'Asfalt'». Tromsø 28.11.1951.

272 RA, Krigsgravtjenesten, eske 26-35. Notat. «Forsvarsdepartementets forberedelse og ledelse av gjennomføringen av operasjon asfalt». 22.10.1951. 


\subsection{Mottakelsen på Tjøtta}

Forberedelsene for mottakelsen av liksekkene på Tjøtta startet i begynnelsen av oktober 1951. Ved mottakelsen var det viktig at det var tilstrekkelig med lastemannskap tilgjengelig, og at det var bulldosere klare til gjengravingen på det nye gravstedet. Kaptein Syvertsen hadde ansvaret for arbeidet med gravleggingen, og Vegvesenet fikk oppdraget med å stille med mannskap til arbeidet med både lossing og gravlegging. Byråsjef Kornelius Halsne ved Sentralkontoret for krigsgraver var opptatt av vaktholdet ved ankomsten, og mente at dette ikke ville bli problematisk siden befolkningens innstilling til krigskirkegården på Tjøtta var meget positiv. ${ }^{273} \mathrm{Halsne}$ hadde også bedt feltprest Finn Guttormsen sjekke at de lokale myndighetene på Tjøtta hadde gitt de nødvendige tillatelsene til å etablere kirkegården. Ordføreren, formannen i helserådet, distriktslegen og presten på Tjøtta ble kontaktet for å få klarert dette. ${ }^{274}$ Dette ble gjort så sent som 8 . oktober 1951, og det tyder på at norske myndigheter har hatt det svært travelt og var usikre på om krigskirkegården kunne bli lagt til Tjøtta eller ikke.

For Sentralkontoret var det viktig at transporten fra losseplassen på Søvik og til gravplassen på Tjøtta ble gjennomført så raskt som mulig. Byråsjef Halsne la vekt på at nødvendige avtaler angående transporten bare ble gjort med én mann. Han foreslo at kaptein Syvertsen skulle kontakte Vegvesenets oppsynsmann eller en annen for å forsikre seg om at et nødvendig antall biler ble stilt til disposisjon for transporten. Det var dessuten viktig å få tak i vaktmannskap til lastebilene og vakter både på kaia og kirkegården. Halsne var opptatt av at publikum måtte holdes borte fra brygga under lossingen, og at hele området omkring gravplassen måtte sperres av for tilskuere mens gravleggingen foregikk. For å unngå for mye publikum ved utlastingen var det viktig at tidspunktet for skipets ankomst ikke ble kunngjort, men bare meddelt til dem som måtte være til stede. Sjefen for IR 14 (infanteriregiment nr. 14), oberst Hauglie, skulle kontaktes om det nødvendige vaktholdet. Det var opp til Vegvesenets mann å skaffe tilstrekkelig mannskap til gravleggingen. Angående overvåking på lossestedet for skipet på Søvik var det skrevet til Justisdepartementet. Etter planen skulle militær og politimessig overvåking samordnes. ${ }^{275}$ Med tanke på hvor omfattende operasjonen var, virker det som om både Sentralkontoret og de involverte departementene var dårlig forberedt på gjennomføringen av gravleggingen på Tjøtta.

I slutten av oktober ankom D/S «Raftsund» Søvik i Sandnessjøen, og etterretningsoffiseren forlot skipet. Ansvaret for lossingen på kaia på Søvik

273 RA, Krigsgravtjenesten, eske 26-35. Notat, Krigsgravtjenesten. Oslo 06.10.1951.

274 RA, Krigsgravtjenesten, eske 26-35. Notat, Krigsgravtjenesten. Oslo 08.10.1951.

275 Ibid. 
ble overlatt til Forsvarsdepartementets representant kaptein Finn Guttormsen. Før etterretningsoffiseren og Sjøforsvarets representanter forlot skipet på Søvik, ba mannskapets tillitsmann om å få skriftlig dokumentasjon på at de skulle ha $20 \mathrm{kr}$ per dag fra første lasteplass til likene var utlosset. ${ }^{276}$

Jan Brovold og Rolf Jægtvik deltok i lossingen fra skipet på havna på Søvik og transporten av liksekkene til Tjøtta krigskirkegård. «Det var et dystert arbeid. Tusenvis av mennesker som var blitt drept og som skulle komme hit», sier Brovold. Han kan huske at de som var møtt frem på kaia på Søvik, ble møtt med følgende hilsen fra kapteinen om bord på D/S «Raftsund»: «Ta det rolig folkens, her er bare døde folk om bord!» Brovold minnes at lasterommene var fullstappet av sekker med likrester. «Det var helt fullt, helt opp til romluka. De lå som murstein, både for og akter.» ${ }^{277}$

Brovold var med i lossegjengen på fem mann fra Vegvesenet som hadde fătt oppdraget. Han stod på kaia og tok imot nettet fylt med sekker som ble løftet fra skipene og over i en lastebil. Selv slapp han den mest ubehagelige jobben, nede under dekk blant alle sekkene i lasterommet. Likevel var det en bedrøvelig jobb også på kaia. Noen av sekkene var åpne, og de kunne se likene i en og annen sekk. Han kan ikke huske at det var så mye lukt på kaia, men det var det nede i lasterommet. Der måtte de lufte. Brovold og de andre arbeidskarene brukte sine egne klær, som de brente etter utført oppdrag. De fikk tilbud om å låne klær om bord, men takket nei. Han husker at mannskapet om bord hadde store forklær og gummihansker, som de ble tilbudt. Klærne lå framme i skipet og var brukt av mannskapet da de tok sekkene om bord. «Hodejegerne har brukt dem», sa båtsmannen. Brovold og arbeidsmennene på kaia foretrakk sine egne klær. ${ }^{278}$

Tre-fire lastebiler fra Søvik ble satt inn i transporten av sekkene fra kaia til krigskirkegården. Rolf Jægtvik forteller at om lag 70 liksekker fikk plass på lasteplanet når disse ble stablet tett. På Tjøtta var Jægtvik med i farens lastebil som ble brukt til oppdraget. Lastebilen kjørte ned i den store gropa som hadde blitt gravd ut på ei vid slette på Tjøtta. Deretter ble sekkene løftet av lasteplanet. Det var to mann oppå bilen og minst fire nede i gropa som la sekkene der de skulle ligge, minnes Jægtvik. Alle ble lagt ut på samme måte på krigskirkegården, både de navngitte på felt $\mathrm{A}$ og de ukjente på felt $\mathrm{B}$. Når de la ut sekkene med de døde, fulgte de et kart som viste hvor sekkene skulle ligge. De måtte være pinlig nøyaktige for at plasseringen av de ofrene som var navngitte, skulle bli riktig. Arbeidet tok sin tid, og Jægtvik forteller at de holdt på i en uke. Brovold, Jægtvik og de andre arbeidsmennene fikk jobbe i fred for lokalbefolkningen.

276 RA, Krigsgravtjenesten, eske 26-35. Rapport. «Operasjon asfalt». Tromsø 24.11.1951.

277 Helgelands Blad, 29.04.2011.

278 Ibid. 
De kan ikke huske at det var noe vakthold, men folk holdt seg likevel borte. Arbeidsmennene fra Vegvesenet ville egentlig ikke ha lossejobben. «Vi nektet. Vi skulle ikke være med på det. Men så var det noen som lovte at vi skulle få så god betaling», forteller Brovold. To-tre mann sa likevel nei og ble ikke med. De syntes det var et makabert arbeid. Brovold forteller at de ikke ble truet til å delta i arbeidet, men de fikk et hint om at de kunne bli innkalt til militæret, og da kunne de bli kommandert til å delta. Disse opplysningene kom fra tilsynsmannen i Vegvesenet på Søvik. Svigerfaren til Brovold ble beordret til å delta i arbeidet siden at han jobbet i administrasjonen ved Vegvesenet. Arbeidsmennene ble forbannet da de oppdaget at de ikke ville fă den lønnen de var lovet, på 20 kroner i timen. Etter at de truet med streik, endte de opp med en lønn på 17 kroner i timen. Brovold og Jægtvik fikk ikke beskjed om ikke å snakke om det de hadde vært med på. Men tilsynsmannen fra Vegvesenet ga dem klare formaninger om å være stille mens de jobbet. «Han sa at vi ikke måtte skråle for dette var alvorlige greier, og det hadde han jo rett i», forteller Brovold. ${ }^{279}$ En del navnelapper hadde løsnet fra liksekkene da de ble fraktet på land. Brovold plukket opp mange navnelapper som lå på kaia og andre steder. På Tjøtta skulle de navngitte døde gravlegges under en navneplate, men både Brovold og Jægtvik føler seg sikre på at mange ikke havnet der de skulle. ${ }^{280}$

Kort tid etter at mesteparten av «Operasjon asfalt» var gjennomført, ble oppdraget drøftet av sentrale myndigheter, som ga oversikt over arbeidet og innrømmelsene om feil ved gjennomføringen av arbeidet fra Forsvarets side. I forbindelse med oppgravingen og transporten til Tjøtta var man svært opptatt av å ikke skape misnøye blant befolkningen. Men det skulle vise seg at det var andre hendelser som skapte sterke protester. Dette gjaldt norske myndigheters behandling av monumenter og minnesmerker over de sovjetiske ofrene. Som vi har sett tidligere, var monumentene et problem i forbindelse med oppgravingen. Fra Forsvarets side ble det innrømmet at kritikken rettet mot hvordan operasjonen ble gjennomført, delvis var berettiget. Løytnant Snefjellå i Sjøforsvarskommando Nord-Norge ga sine merknader til gjennomføringen av «Operasjon asfalt». Han påpekte at de lokale myndighetene i mange tilfeller ikke var blitt tilstrekkelig informert på forhånd om myndighetenes planer for flyttingen av gravene. Selve oppgravingsarbeidet var ikke alltid blitt gjennomført under tilstrekkelig ansvarlig kontroll. Lagringen av de oppgravde ofrene kunne med rette i mange tilfeller kritiseres sterkt. Løytnanten fremhevet at i enkelte tilfeller var gravsteiner fjernet eller ødelagt uten at dette i og for seg hadde vært absolutt nødvendig. Hans hovedinntrykk var at selve gjennomføringen av operasjonen hadde såpass mange feil at man på

279 Helgelands Blad, 29.04.2011.

280 Ibid. 
norsk side og fra offisielt hold måtte være meget forsiktige med å innlate seg i en prosedyre om de enkelte tilfellene. Til slutt viste han til at det kunne slås fast at de instruksene som var gitt om gjennomføringen av operasjonen, var ment for at arbeidet skulle bli utført på en pietetsfull måte. ${ }^{281}$ På grunnlag av disse innrømmelsene fra Forsvarets side er det åpenbart at instruksene for gjennomføringen av operasjonen flere steder ikke ble fulgt.

\subsection{Reaksjoner fra lokalbefolkningen}

Både under og etter at flyttingen var gjennomført, ga den norske lokalbefolkningen uttrykk for sin kritikk av arbeidet. De negative reaksjonene var som regel knyttet til ødeleggelsen av monumentene over de sovjetiske ofrene. Det ble tatt lite hensyn til lokalbefolkningens mening, men lokale myndigheter lyktes til en viss grad å ta vare på monumenter som ikke ble ødelagt eller flyttet. På grunn av de mange misvisende avisartiklene så Utenriksdepartementet seg nødt til å redegjøre for de faktiske forholdene i en pressemelding i september 1951. Her viste departementet til de utilfredsstillende forholdene omkring gravene og ønsket om å få reist varige og verdige anlegg til minne om de sovjetiske ofrene som døde i Norge under krigen. I pressemeldingen ble det også vist til at regjeringens toårsplan sommeren 1951 avvek fra tidligere planer, men man mente at en sterk konsentrasjon av gravene ville gi de mest tilfredsstillende anleggene. ${ }^{282}$

Engasjementet mot flyttingen av de sovjetiske krigsgravene i Nord-Norge var stort. Vitnebeskrivelser, avisartikler og leserinnlegg viste at folk var opprørt over det som skjedde. Flere tiår etter flyttingen var minnene fremdeles sterke for noen. I radiodokumentaren Kirkegårdskrigen på NRK flere tiår etter flyttingen av gravene, forteller en mann om inntrykkene fra oppgravingen av de sovjetiske ofrene i Nordland i 1951:

Alle som bivånet det der på nært hold, var rystet. De hadde noen plastsekker som disse beinrestene skulle puttes i, men som regel var det bare kraniet de fikk med seg, for det øvrige lå jo igjen. Det lå strødd rester etter disse gravrøverne, som jeg vil kalle det. Det var jo lite verdig en nasjon som oss. Du får unnskylde uttrykkene, men jeg blir veldig opprørt når jeg snakker om det. ${ }^{283}$

281 RA, Krigsgravtjenesten, eske 26-35. Udatert rapport. «Sammendragning av russiske krigsgraver i Nord-Norge».

${ }^{282}$ RA, Krigsgravtjenesten, eske 26-35. Pressemelding. Utenriksdepartementet Oslo 19.01.1951.

283 NRK P2, Kirkegårdskrigen. 08.09.1996. 
En gruppe arbeidere i Oslo henvendte seg til Stortinget og regjeringen, og uttalte at det var en æressak og plikt å verne om de sovjetiske krigskirkegårdene. Nordland Arbeiderblad skrev om arbeidernes protester «mot den forferdelige gravskjending som har foregått i Nord-Norge». ${ }^{284}$ Arbeiderne krevde at de som hadde mistet livet i kampen for Norges frigjøring, måtte få hvile i fred. Minnesmerkene som var ødelagt, måtte erstattes med nye og settes på plass. Det var en æressak og en plikt, krevde arbeiderne. ${ }^{285}$ Samme avis publiserte også en liten notis fra den sovjetiske forfatteren A. Surkov, som skrev: «Soldatene fra Stalingrad krever ingen takk. Men de har rett til å kreve at en ikke spytter på dem. Det blir mørkt i hjertet når vi leser om det som nå foregår i Norge. ${ }^{286}$ En anleggsarbeider opplevde høsten 1950 at et gravmonument ved Bjørnelva ble sprengt i stykker. Kollegaene til arbeideren hadde stelt og pyntet på gravstedet. De hadde også satt opp et lite gjerde rundt monumentet. Anleggsarbeideren fortalte til Nordland Arbeiderblad at det en dag dukket opp en mann som sprengte gravmonumentet i lufta. Da røyken drev bort etter eksplosjonen, lå monumentet strødd i biter på bakken og gjerdet var revet bort. På monumentets forside hadde det vært en plate hvor de drepte krigsfangenes navn var påført. De var pint til døde, og det var nokså mange navn, fortalte anleggsarbeideren. Da han hadde kommet seg etter opplevelsen, løp han ut på veien og hyttet med neven mot «gravskjenderens» bil. Da kom mannen ut av bilen og var veldig morsk. Dette var etter all sannsynlighet kaptein Arntzen fra Krigsgravtjenesten. Arbeideren uttalte at han var for sint til å bli redd. På spørsmål om hvorfor monumentet over disse stakkars menneskene ble ødelagt, fikk han til svar at «det er så uhyggelig for turistene å se disse russiske gravmonumentene stå slik omkring». ${ }^{287}$

Minnesmerket som ble reist av de gjenlevende krigsfangene på Tømmernes i Hamarøy, ble også sprengt i stykker. Avdukingen av minnesmerket hadde vært en stor begivenhet for alle som bodde på Tømmernes, og krigsfanger av flere allierte nasjoner i tillegg til de sovjetiske hadde deltatt. Folk som hadde bodd like ved fangeleiren, hadde vært vitne til mange blodige tragedier, og de følte at kirkegårdens fred var ødelagt på en provoserende og brutal måte. Kirkegården var blitt et fredet sted, og minnene lot seg hverken utslette eller sprenges bort, var folkets holdning. Om lag 30 meter fra den sovjetiske krigskirkegården lå det en tysk kirkegård, og her var minnesmerket og gravene urørt. Dette var uforståelig, og folk følte at morderne ble æret ved å fjerne de

${ }^{284}$ Nordland Arbeiderblad, 09.10.1951.

285 Ibid.

286 Ibid.

287 Nordland Arbeiderblad, 14.06.1951. 


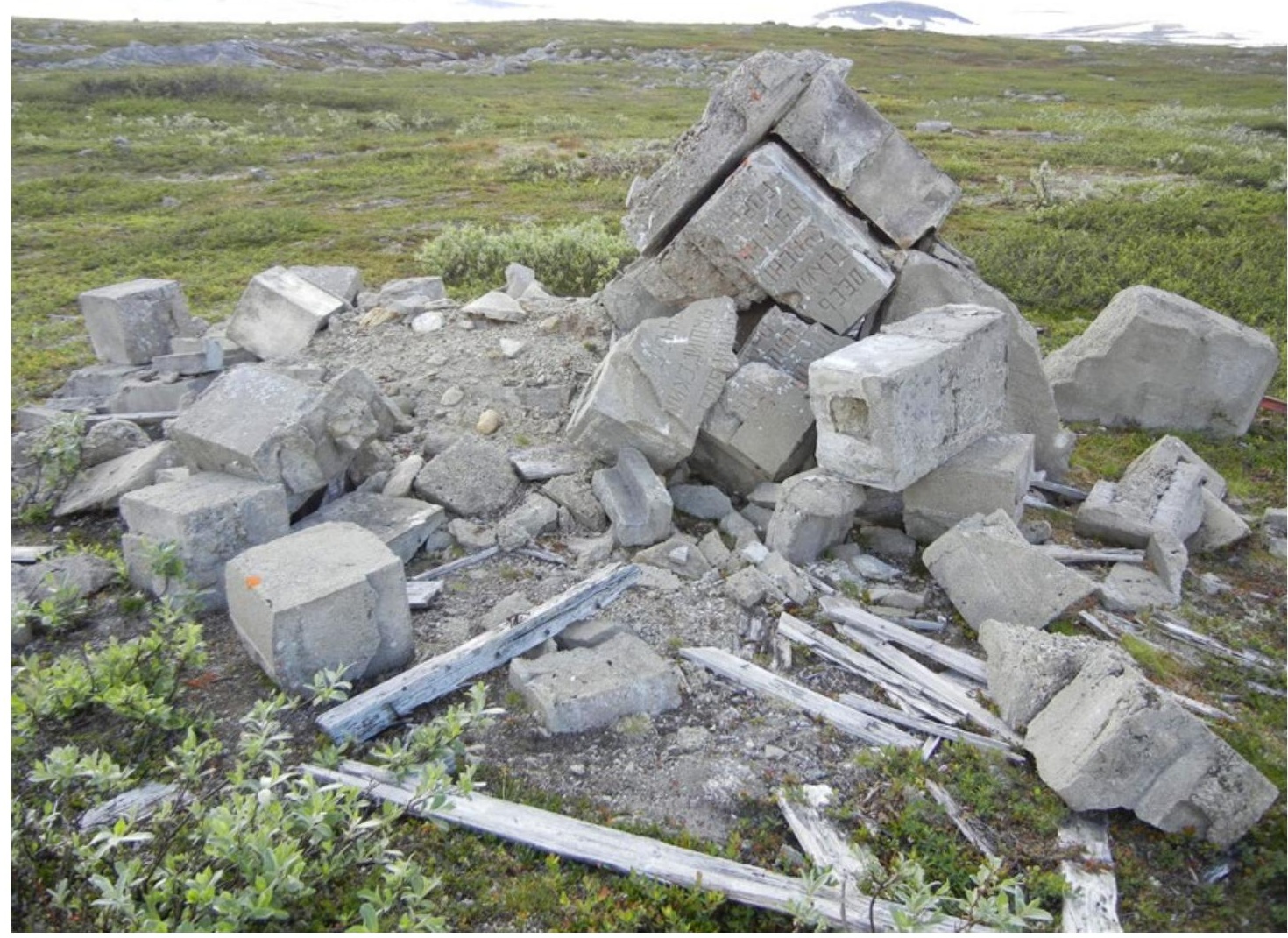

$\varnothing$ delagt monument, Bjørnelva 2012. Foto: Charles Utvik.

myrdede. ${ }^{288}$ Denne oppfatningen om ofrene og drapsmennene var basert på hvordan NKPs hovedorgan Friheten oppfattet befolkningens vurdering.

Flyttingen av gravene skapte ingen negative reaksjoner nasjonalt, men lokalt ble det protestert flere steder. Lokalsamfunn i Narvik og Beisfjord, Harstad, Mo i Rana og Tromsø forsøkte å stoppe oppgravingen, men de lyktes bare i Mo i Rana. I Nordland Arbeiderblad kunne man lese at de sovjetiske ofrene på krigskirkegårdene i Narvik og Beisfjord ble gravd opp uten at de kommunale myndigheter var informert. Oppgravingen var startet i august 1951 og syv lik var gravd opp og lagt i papirsekker i et skur som var satt opp i forbindelse med oppgravingene. Rådmannen i Narvik hadde ikke kjennskap til hva som foregikk på krigskirkegården, og uttalte at det ikke forelå noen korrespondanse mellom den sovjetiske ambassaden og Narvik kommune om flytting av gravene. Rådmannen viste til at det tvert om forelå skriv om restaurering av kirkegården. På et tidligere bystyremøte hadde kommunen tatt opp en plan for restaurering av to krigskirkegårder. Etter kontakt med den sovjetiske ambassaden var planen godtatt med noen tilføyelser fra deres side. Rådmannen mente at det var merkelig at oppgravingen, ledet av en militærkaptein fra departementet, ble gjennomført uten at kommunale

288 Friheten, 20.10.1951. 
myndigheter var informert. På krigskirkegården var arbeidet med oppgravingen kommet godt i gang uten at Ankenes kommune i Beisfjord hadde fătt noe skriv fra ambassaden om flytting av gravene. På samme vis som Narvik hadde Ankenes kommune planer for restaurering av krigskirkegården. En av arbeiderne ved oppgravingen i Narvik hadde fortalt at de hadde fătt ordre om at gravstøtten og det øvrige arbeidet som de sovjetiske overlevende krigsfangene hadde nedlagt på kirkegården, skulle fjernes, samtidig som alle likene skulle graves opp og flyttes sørover. ${ }^{289}$ I Narvik tok to sovjetiske journalister kontakt med kommunister i byen for å få informasjon om stemningen blant folk angående oppgravingen og flyttingen av de sovjetiske ofrene. Fra norsk side ble det antatt at journalistene ville ta bilder av gravplassene. ${ }^{290}$ Disse eksemplene fra de ulike stedene viser at norske myndigheter ønsket å forhindre at det ble tatt bilder ved oppgravingene. Dette hadde åpenbart årsak i at «Operasjon asfalt» var å betrakte som en hemmelig aksjon.

Avisen Nordland Arbeiderblad trykte i september 1951 en artikkel med overskriften "gravskjending som politisk kampmiddel». I artikkelen ble det uttrykt forbauselse over at de sovjetiske gravene ble ødelagt samtidig som de tyske gravene ble pusset opp. Arbeiderne i oppgravingsarbeidet i Narvik og Beisfjord ble beskrevet som «frie likrøvere». ${ }^{291}$ Det ble også påpekt at det samme gjentok seg ved oppgravingsarbeidet i Sørfold:

Ved rikelig tildelte brennevinsrasjoner har man erkjent hva slags folk det er som er skamløse nok til å påta seg denne skitne jobb. Det fortelles også at disse kadavrene skal få utbetalt $40 \mathrm{kr}$. pr. dag pluss 5 kroner for hver hodeskalle ved siden av brennevinsrasjonen. ${ }^{292}$

I Beisfjord var det mange som engasjerte seg i protestene, og 200 personer møtte opp til en minnestund på krigskirkegården. Oppgravingen ble betraktet som gravskjending, og det ble forlangt at monumentet skulle bli stående. Lokfører Kristian Edvardsen holdt en følelsesladet tale på minnestunden:

Om vi kunne se de menneskeskjebner som ble begravd sammen med de som ble mishandlet her på stedet ville vi at hver eneste en av dem hadde en mor eller en far som elsket dem høyt. (...) Og kanskje den dag i dag, går det en sørgende far og mor langt borte i det fremmede land og tenker på gutten sin, som de var så glad i og som de ventet seg så mye av. ${ }^{293}$

289 Nordland Arbeiderblad, 28.08.1951.

290 RA, Krigsgravtjenesten, eske 26-35. Avskrift. Utenriksdepartementet, udatert.

291 Nordland Arbeiderblad, 15.09.1951.

292 Ibid.

293 Nordland Arbeiderblad, 29.09.1951. 
Edvardsen sa også at folk ble sjokkert da de hørte ryktet om at gravene ble skjendet og jevnet med jorden. Nå hadde myndighetene selv gitt ordre om at gravfreden skulle brytes. Ingen ville ha protestert dersom oppgravingen var et ønske fra de etterlatte eller fra landet hvor ofrene hadde sitt hjemsted. Men her dreide det seg om en brutal ordre fra militæret. Det var åpenbart at sympatien for de døde sovjetiske krigsfangene var stor i Beisfjord. Befolkningen hadde gjort hva de kunne for å lindre fangenes lidelser, påpekte Edvardsen, men ble hjelpeløse vitner til tyskernes bestialske oppførsel mot ofrene. ${ }^{294}$

Dagen etter minnemøtet i Beisfjord ble det hevdet i avisen Nordland Arbeiderblad at Dagbladet forsøkte å gjøre tragedien med krigskirkegårdene til en skitten løssalgsaffære. I Dagbladet var det et stort oppslag om at «Sovjetunionens ambassade søkte å forkludre den norske regjerings vedtak ved å sende 2000 kroner for å vedlikeholde gravene etter at den norske regjering hadde besluttet å tilintetgjøre dem». I Nordland Arbeiderblad viste man til at graverne Dagbladet hadde snakket med, hadde lagt ned arbeidet og nektet å utføre oppdraget før regjeringen hadde avklart saken med den sovjetiske ambassaden. For å poengtere enigheten i saken ble det fremhevet at Narvik formannskap skulle gi departementet beskjed om at de ønsket å sette i stand kirkegården for falne sovjetiske soldater. Planen for dette var ferdig og godkjent av den sovjetiske ambassaden, som også skulle betale anlegget og vedlikeholdet. Til slutt i artikkelen ble det gjort oppmerksom på at: «(...) dersom noen skulle tenke på å fortsette gravskjendingen etter alle disse hendelser, har de ingen unnskyldning. Og deres navn vil bli offentliggjort. ${ }^{295}$ I samme avis viste man også til hva som ble gjort med de franske gravene i Narvik. Da de franske gravene hadde blitt flyttet, skjedde det i samråd med og etter initiativ fra franske myndigheter. Også selve oppgravingen av de franske gravene foregikk forskriftsmessig, ifølge ordføreren i Narvik. I tillegg ble det gjennomført en oppussing og restaurering av den tyske krigskirkegården. Blant annet var korsene tatt ned og sendt til oppmaling. Det dreide seg om 100 kors som var tatt ned for å bli gjort fine og presentable for turistene. ${ }^{296}$

I Harstad var man særlig opptatt av at monumentet på Trondenes kirkegård ikke skulle bli flyttet. Forsvarsdepartementet påpekte overfor Harstad kommune at monumenter og minnesmerker vanligvis ikke ble fjernet under flyttingen av de sovjetiske gravene i Nord-Norge. Det var heller ikke hensikten å overføre noen minnesmerker til den nye sentralkirkegården på Tjøtta. Departementet fremhevet også at dette var tatt med i instruksen til kaptein Arntzen. Monumentet på Trondenes kirkegård i Harstad var ikke plassert

294 Ibid.

295 Nordland Arbeiderblad, 27.09.1951.

296 Nordland Arbeiderblad, 15.09.1951. 
direkte over noen graver slik at flytting eller demontering av monumentet var nødvendig, ifølge departementet. Harstad kommune fikk tillatelse til å la monumentet bli stående eller eventuelt bli flyttet til et annet sted på kirkegården. ${ }^{297}$ Med tanke på det store antallet monumenter og minnesmerker som ble ødelagt under flyttingen av gravene, er det åpenbart at kaptein Arntzen ikke har fulgt instruksen som ble gitt av Forsvarsdepartementet.

Oppgravingen av de sovjetiske ofrene i Harstad ble beskrevet som gravskjending i avisen Nordland Arbeiderblad. Prost Ole Steinholt var av en annen oppfatning, og påpekte at dette ikke kunne omtales som gravskjending. Journalisten var ikke overbevist og trykte et bilde av den russiske krigskirkegården i Harstad. Bildet viste at hodeskaller og andre skjelettdeler var samlet i haugevis, dekket av presenninger, mellom gravene. Korsene var enten blitt liggende igjen eller reist vilkårlig mot gjerdet. Journalisten påpekte at en slik oppgraving ikke var ærbødig, og at den ikke sørget for at kroppsdelene ble samlet på korrekt måte. Han mente dette var i strid med alle lover og bestemmelser som gjaldt for slikt arbeid. Prost Steinholt ble også kritisert for å ha satt i gang oppgravingen uten å avvente stiftsdireksjonens melding om saken. Dette resulterte i at biskop Krohn-Hansen ikke kjente til saken da Steinholt anskaffet folk til arbeidet med oppgravingen. Journalisten mente at denne saken sikkert ville åpne øynene på mange i prostens sognekrets og avsløre hans sanne natur. Skoleinspektør Dahl var av den oppfatning at kommunistlaget skulle ha påtatt seg vedlikeholdet av krigskirkegården på Trondenes, men ifølge ordfører Simensen måtte dette bero på en misforståelse. Han oppga at kommunistlaget allerede for to år siden hadde skrevet til Harstad kommune at de ikke kunne påta seg ansvaret for vedlikeholdet siden dette var en kommunal oppgave. Kaptein Syvertsen, som var regjeringens representant, uttalte i avisen at oppgravingen i Harstad foregikk etter regler og forskrifter og så sømmelig som mulig. ${ }^{298}$

Harstad formannskap protesterte mot det de kalte hærverk på de sovjetiske kirkegårdene. Formannskapet ville be om at oppgravingen på krigskirkegården på Trondenes ble stoppet inntil det forelå nærmere opplysninger fra Hålogaland stiftsdireksjon. Det ble bestemt at de skulle søke sentrale myndigheter om å få beholde den sovjetiske krigskirkegården på Trondenes. ${ }^{299}$ Flyttingen av gravene ble utsatt i noen dager på grunn av protestene i Harstad. For folk flest var det uforståelig at det var nødvendig å flytte levningene etter sovjetborgerne helt til Tjøtta. Særlig reagerte de på at de som var gravlagt på

297 RA, Krigsgravtjenesten, eske 26-35. «Den russiske krigskirkegård på Trondenes». Oslo 01.10.1951.

298 Nordland Arbeiderblad, 29.09.1951.

299 Nordland Arbeiderblad, 15.09.1951. 
kirkegårder, måtte flyttes. ${ }^{300}$ Ved oppgravingen på Trondenes ble det funnet 403 lik. Antallet gravlagte som var oppgitt i tidligere lister, var på 800 døde. Sognepresten og graveren i Trondenes mente at antallet som var funnet ved oppgravingen stemte med de faktiske forholdene. Oppgaven over døde som tyskerne etterlot seg, oppga fangenummer på om lag 400 sovjetiske krigsfanger. På monumentet som ble reist av russerne i 1945 på Trondenes kirkegård, står det på inskripsjonen at antallet gravlagte var 800 krigsfanger. På bakgrunn av antallet døde som ble funnet under oppgravingen i 1951, antok man at det var antallet sovjetiske krigsfanger som oppholdt seg i Trondenes under krigen som var blitt oppgitt som gravlagte på inskripsjonen til monumentet. ${ }^{301}$

Kommunistenes avis Friheten siterte i november 1951 et øyenvitne til oppgravingen på Fauske kirkegård. Vitnet fortalte om makabre hendelser som han beskrev som det reneste sirkus på kirkegården. Arbeidet hadde foregått under rop og skrik, og noen av hodeskallene var blitt kastet opp i lufta og trillet seks-syv meter før de ble samlet i sekker og kjørt bort. En kontroll av gravene ville vise hvor lite pietet graverne hadde vist på denne gravplassen, fortalte vitnet. Gravmannskapet hadde også veltet minnesmerket og gravd det ned. Kirkegårdsgraveren, som hadde nektet å delta i gravearbeidet, hadde bekreftet dette. De sovjetiske gravene i Fauske lå like ved den tyske gravplassen, der korsene over gravene stod i snorrette rekker. Det var tydelig at denne gravplassen var godt vedlikeholdt. Journalisten fremhevet at det ga et underlig inntrykk å se de tyske korsene og vite at på den nakne sletta like ved hadde kroppene til døde allierte ligget inntil for kort tid siden. ${ }^{302} \varnothing$ yenvitnets historie om oppførselen til gravmannskapet er ikke bekreftet fra andre kilder.

Under oppgravingene i Fauske samlet folk seg ved kirken for å demonstrere, uten at det fremkom noen trusler mot arbeiderne. Arbeiderne ble imidlertid nektet hus og mat av kommunistene i Fauske. Under arbeidernes midlertidige fravær hadde en ukjent person, som ble antatt å være kommunist, tatt en knokkel fra et av likene. Denne hadde han plassert på et gjerde og hengt en ny oljetrøye ved siden av. Lederen for arbeidet på Fauske kirkegård mente at dette var gjort for å gi inntrykk av at oppgravingen ble gjennomført på en hensynsløs måte. I notatene angående oppgravingen påpekes det stadig at det var antatte kommunister som stod bak protestene på de ulike stedene. Det ble ofte oppgitt at de som stod bak protestene, var registrerte kommunister. I Kroken i Salten hadde en kommunist fortalt at han hadde kontakt med den sovjetiske ambassaden, som hadde gitt ham penger for å

\footnotetext{
300 Leserinnlegg i avisen Helgeland, 09.10.1951.

301 RA, Krigsgravtjenesten, eske 26-35. Operasjon «Asfalt». Troms fylke. Liste over gravsteder. Udatert.

302 Friheten, 07.11.1951.
} 
passe og stelle russergravene. Lederen for oppgravingen oppfattet mannens protester mot oppgravingen som en reaksjon på at han nå mistet denne godtgjørelsen. ${ }^{303}$ Gravmonumentet i Kroken ble fjernet i 1951. Gravplassen er i dag markert med en standard minnestøtte nedsatt av Krigsgravtjenesten.

Adkomst til minnestedet i Kroken er merket, men lite er blitt gjort for å ta vare på området ved minnesmerket, som er svært gjengrodd.

I Salangen ble arbeidet med oppgravingen beskrevet som plyndring i avisen Nordland Arbeiderblad. Mandag den 1. oktober hadde en stor militær lastebil stoppet ved porten til Nordstrøm kirkegård. Fem menn fra Salangen i alderen 20 til 50 år kom ut av lastebilen og startet oppgravingen av de sovjetiske ofrene. Det var uforståelig at mannfolk fra bygda kunne utføre dette "gravplyndringsarbeid» selv om de tjente opp til 250 kroner per mann per dag for jobben. For innskriveren var det uforståelig hvorfor de jordfestede sovjetiske likene skulle flyttes til sekker fra en innviet kirkegård. Da han stod på kanten av den oppgravde fellesgraven på kirkegården, hadde han en klar følelse av at gravfreden var ødelagt. ${ }^{304}$

I Forsvarsstabens notater angående arbeidet med oppgravingen ble det vist til en artikkel i Nordland Arbeiderblad den 9. oktober 1951. Avisen betraktet oppgravingen som gravskjending og fremhevet at folket ikke lot seg føre bak lyset. Etter at folk var blitt oppmerksomme på de nærmere omstendighetene ved flyttingen av gravene i Hattfelldalen, var ingen villige til å stille opp for å utføre det som ble omtalt som et skjendig oppgravingsarbeid. Det ble i denne sammenhengen antatt at det bare hadde vært mulig å skaffe arbeidere til oppgravingsarbeidet i distriktene ved å gi inntrykk av at oppgravingen skjedde i forstålse med sovjetiske myndigheter og etter de pårørendes egne ønsker. I artikkelen ble det uttrykt at det ikke fantes en eneste hederlig arbeider som ville ha noe med oppgravingen å gjøre. ${ }^{305}$

303 RA, Krigsgravtjenesten, eske 26-35. Notat. «Ad telegram 06.10.1951 russergraver». Udatert.

304 Nordland Arbeiderblad, 09.10.1951.

305 RA, Krigsgravtjenesten, eske 26-35. «Skriv mottatt fra Tromsö den 10.10.1951. Til sjefen for F.st. II for videreforsendelse til statssekretæren. Asfalt». Forsvarsstaben, Oslo 10.10.1951. 
På gravplassen i Dunderland utenfor Mo i Rana avdekket det norske brigadepolitiet i juni 1945 dødsårsakene til 27 sovjetiske ofre. 13 av fangene døde av sult og fem av disse døde i maidagene etter at krigen var slutt. Tre av krigsfangene døde under sprengningsarbeid på jernbaneanlegget i Dunderland. Flere krigsfanger ble skutt av tyske underoffiserer fra Organisation Todt $^{306}$ og SS. En av disse fangene ble skutt fordi han ikke ville ta imot en sigarettstump av en tysker. To av fangene ble skutt av det tyske grensepolitiet på grensen til Sverige under et rømningsforsøk i midten av juli 1943. Fem fanger ble skutt i fangeleiren på Messingslett i Dunderland. Feltwebel (sersjant) Göbl skjøt en av fangene «da denne ikke var kamerat». ${ }^{307} \mathrm{De}$ sovjetiske ofrene mistet livet på grunn av bagateller etter å ha falt $\mathrm{i}$ unåde hos de tyske tjenestemennene.

I 1951 var oppgravingen av ofrene i Dunderlandsdalen fullført, men det lå fremdeles sekker med lik slengt i en haug på Brennheia gravsted. Monumentene som var blitt satt opp i 1945, var helt eller delvis forfalt. Folk i området var skamfulle, forbausede og forargede over at gravstedene ikke var blitt vedlikeholdt. L.M. Hansen fra Storforshei var med og besøkte gravstedene i Dunderlandsdalen. Han fortalte at det var en utbredt oppfatning blant folk at de døde russerne burde få ligge i fred. Det var den minste ære Norge kunne vise dem. ${ }^{308}$ Graveren i Mosjøen fortalte til avisen Nordlands Folkeblad at han hadde fått ordre om å brenne likene som ble gravd opp. Journalistene rapporterte at det ble politiets oppgave å etterforske denne nifse saken. Etter deres oppfatning hadde de aldri sett en så total mangel på respekt for menneskeverd på en fredelig norsk kirkegård. I en skriftveksling mellom Utenriksdepartementet og den sovjetiske ambassaden ble det opplyst at flyttingen ble gjennomført av praktiske grunner, uten at det ble sagt hva dette var. Ambassaden

306 Organisation Todt var en halvmilitær tysk organisasjon oppkalt etter ingeniør Fritz Todt. Han ble høyt verdsatt av Hitler på grunnlag av arbeidet med Tysklands «Westwall», befestningsanlegget ved grensen mot Frankrike, som ble bygd i samarbeid med Wehrmacht.

307 RA, RAFA-1939. Forsvaret, major Leiv Kreybergs arkiv. «Anmeldelse, fortegnelse over mannskaper som er gravlagt paa gravplassen i Dunderland». Dunderland 06.06.1945.

308 Nordland Arbeiderblad, 09.10.1951. 
hadde ikke funnet noen praktiske grunner her, og hadde tilbudt seg å holde gravene i orden for egen regning. Men statssekretæren hadde avvist dette og sagt at arbeidet ville bli gjennomført. ${ }^{309}$

Mobiliseringen mot flyttingen av gravene i Mo i Rana er blitt beskrevet som en unik hendelse, som hadde sine forutsetninger i lokale forhold. Disse forholdene var solidariteten mellom befolkningen og de sovjetiske krigsfangene, samt kommunistenes evne til å mobilisere befolkningen i Mo i Rana. ${ }^{310}$ Befolkningen i Mo i Rana hadde i 1951 fremdeles sterke minner om de sovjetiske krigsfangene og ønsket at deres gravsted og minnesmerke skulle få stå i fred. Byens befolkning hadde hjulpet mange av de sovjetiske krigsfangene som satt i tyske leirer i byen og området rundt. De forpinte fangenes lidelser av sult og nød hadde rystet byens befolkning dypt, og til tross for stor personlig risiko hadde særlig mange kvinner hjulpet fangene med mat. Folk hadde gitt uttrykk for at de var tilfreds med at disse allierte, som helt frem til døden tok lidelsene med en ufattelig sinnsro og tapperhet, var stedt til hvile under verdige forhold i byen. Gravene ville alltid minne dem om «evig

309 Nordlands Folkeblad, 28.09.1951.

310 Eidsaune, Thor Helge: «Kirkegårdskrigen», i Årbok for Rana. Mo i Rana 1999: 29-30. 
vennskap over landegrensene». Det var årsaken til at flyttingen ble betraktet som gravskjending. På tross av protester fra de avdødes pårørende gjennom den sovjetiske ambassaden i Norge ble de døde forsøkt ført vekk fra Mo kirkegård til en avsidesliggende gravplass ut i øygarden og minnesmerket skulle fjernes. Befolkningen var opprørt over planene og protesterte kraftig mot det de betraktet som et brudd på norsk pietetsfølelse. ${ }^{311}$

Kommunistene hadde tidlig markert sin motstand mot flyttingen av gravene og hadde hele tiden fingeren på pulsen når det gjaldt befolkningen. På svært kort varsel kunne kommunistene sette hele sin tyngde inn på å stoppe flyttingen. Kommunistene i Mo i Rana organiserte demonstrasjoner. Svært mange møtte frem på kirkegården og stilte seg opp ved inngangsporten, mellom gravene og rundt den sovjetiske gravstøtten. Det ble dessuten slått opp plakater med overskriften «Gravskjending». Plakatene ytret at gravskjending skulle gjennomføres på Mo kirkegård på tross av befolkningens protester. Oppgravingen skulle utføres i all hast som overrumpling for at ikke denne skjendige handlingen skulle hindres, mente kommunistene. Men folket ville stoppe dette. Demonstrantene hevdet at oppgravingen ville føre til streik ved jernverket og på jernbanen. I et opprop stod det: «Også du må gå fra arbeidsplassen og møte frem på Mo kirkegård kl. 7 og vise at det ikke går an å krenke folkets vilje og dets respekt for gravens ro.» ${ }^{312}$ Politimesteren påpekte at det ikke hadde lyktes kommunistene å skape noen opinion på stedet. Videre var hans oppfatning at oppgravingen ikke i nevneverdig grad var noe samtaleemne, men at folk fant det hele til en viss grad unødvendig og støtende. Han hadde ikke inntrykk av at uviljen mot flyttingen av likene skyldtes at likene ikke ble lagt i kister. Hans oppfatning var at kommunistene på stedet hadde en grunn til å gjøre blest om seg selv og håpet at dette kunne komme dem til nytte under kommunevalget. De håpet at saken ville vekke en viss russersympati ved å fremstille det hele som gravskjending og tilsiktet sjikane mot de avdøde russerne, hevdet politimesteren. Det var vanskelig å uttale seg noe om hvordan befolkningen ville reagere da oppgravingen ble satt i verk.

Ifølge politimesteren var ikke saken av en slik art at folk følte seg personlig engasjert, ved at oppgravingen kunne skape demonstrasjoner eller oppløp. Hans inntrykk av kommunistene i Mo i Rana var at de var dyktige debattanter som hadde lett for å hevde seg på møter og forsamlinger, og som la vekt på at det hele gikk for seg i ordnede forhold. Etter hans mening risikerte man neppe håndgripeligheter om militæret gjennomførte oppgravingen. ${ }^{313}$ Kaptein Overdale og kaptein Syvertsen ringte til forsvarsminister Jens Christian

311 RA, Krigsgravtjenesten, eske 26-35. Dokument, «Til folket i Mo». Udatert.

312 Helgeland, 03.11.1951.

313 RA, Krigsgravtjenesten, eske 26-35. Notat. Oslo politikammer. Oslo 12.10.1951. 
Hauge da de innså at vanskelighetene i Mo i Rana ble for store. Arbeidsformannen Tor Normann, som skulle ha med seg elleve mann, var kommet alene til kirkegården. Arbeidsgjengen hans var skremt vekk. Kaptein Overdale mente at oppgravingen kunne begynne om kort tid. Normann opplyste at hans folk ville gjøre arbeidet dersom de ble garantert tilstrekkelig beskyttelse. Overdale ga deretter uttrykk overfor Hauge at arbeidet burde gjøres, men at det ville være langt vanskeligere enn han hadde trodd. ${ }^{314}$ Det var vanskelig å begynne gravingen under forholdene som hadde oppstått. Arbeidsformannen ønsket at hans menn skulle få tilstrekkelig beskyttelse, men Overdale mente at de heller måtte forsøke å få tak i en ny arbeidsgjeng. Overdale ville ha en større politistyrke til beskyttelse ved oppgravingsarbeidet og ønsket å forhandle med arbeiderne på jernverket gjennom LO. ${ }^{315}$

Erling Moe fra NKP holdt en kort tale på kirkegården og presenterte seg for de militære representantene som hadde ansvaret for oppgravingen. Han opplyste at det var samlet ca. 800 mennesker på kirkegården, og at arbeidet var stanset ved Bergverkselskapet Nord-Norge, delvis på Jernverket og andre arbeidsplasser. I tillegg påpekte han at oppgravingen av de sovjetiske gravstedene utvilsomt ville føre til vanskeligheter som ansvarlige myndigheter måtte ta det fulle ansvaret for. Kaptein Arntzen fra Krigsgravtjenesten svarte at han kun stod til ansvar overfor den norske regjering, og etter ordre herfra ville oppgravingen bli satt i gang. Til slutt ga likevel Jens Christian Hauge beskjed om å innstille arbeidet. ${ }^{316}$

Hendelsene i Mo i Rana resulterte til slutt i at forsvarsminister Jens Christian Hauge bestemte at flyttingen av sovjetiske krigsgraver på Mo kirkegård måtte stoppes på grunn av befolkningens motstand. ${ }^{317}$ Jens Christian Hauge skrev senere angående oppgravingen i Mo i Rana, at det kjedeligste ved det som hadde hendt der, ikke var at gravingen ble innstilt, men at en beslutning som var tatt, måtte oppgis på grunn av motstand. ${ }^{318}$

Hauge uttalte på samme tid til avisen Verdens Gang at oppgravingen hadde støtt på tekniske vanskeligheter, og at vedkommende offiser som ledet arbeidet, var tilkalt til Oslo for å avgi rapport om saken. På spørsmål om man hadde gitt opp å flytte gravene fra Mo i Rana til Tjøtta, svarte Hauge at regjeringen hadde i sin note av 10. oktober til Sovjetunionen forklart at gravene til de sovjetiske krigsfangene i Nord-Norge ville bli samlet på Tjøtta. Regjeringen hadde ikke

314 RA, Krigsgravtjenesten, eske 26-35. Notat. «Gravsaken. Mo i Rana». Oslo 02.11.1951.

315 RA, Krigsgravtjenesten, eske 26-35. Intern melding til statsrådens kontor. 02.11.1951.

316 RA, Krigsgravtjenesten, eske 26-35. Notat. «Gravsaken. Mo i Rana». Oslo 02.11.1951.

317 RA, Krigsgravtjenesten, Notat, «Gravsaken Mo i Rana», Oslo den 02.11.1951. På spørsmål om flyttingen av gravene til Tjøtta uttalte forsvarsministeren likevel til NTB at regjeringen ikke hadde endret standpunkt i saken. Jf. Avisen Helgeland 03.11.1951.

318 RA, Krigsgravtjenesten, eske 26-35. Notat. «Gravsaken. Mo i Rana». Oslo 02.11.1951. 
endret sitt standpunkt og overføringen var stort sett gjennomført ellers i landsdelen. Hauge påpekte at alle kunne være forvisset om at kirkegården på Tjøtta ville bli et vakrere og mer verdig minnested over de døde sovjetiske krigsfangene enn de mange spredte og til dels meget små gravplassene som hadde eksistert til nå. I samme innlegg i avisen ble det gitt en redegjørelse fra Norsk-Sovjetisk Samband. Sambandets sentralstyre hadde tidligere rettet en henstilling til regjeringen om å stoppe flyttingen, og bedt om at alt videre arbeid måtte gjennomføres i samråd med Sovjetunionens representanter i Norge. Sambandet viste dessuten til at de hadde medvirket til en samling av sovjetiske soldaters graver på kirkegårdene i Oslo og Stavanger. I motsetning til i Nord-Norge hadde samlingen av gravene i disse byene blitt ordnet i full forståelse mellom Sovjetunionens ambassade og norske myndigheter. ${ }^{319}$ I henstillingen til regjeringen hadde sambandet bedt om varsomhet i gravsaken. De mente at det kunne virke uheldig for utviklingen av den kulturelle og vennskapelige forbindelsen mellom norske og sovjetiske borgere om regjeringen i en så ømtålig sak fortsatte med tiltak som kunne bli misforstått. De påpekte også at det var i samsvar med det norske folks kulturtradisjon og moraloppfatning at det i spørsmål så sterkt knyttet til følelser, måtte vises størst mulig hensynsfullhet overfor de døde soldatenes familier og venner i hjemlandet. I henstillingen beklaget de at offentligheten ikke på et langt tidligere tidspunkt hadde fått fyldig informasjon om planene norske myndigheter hadde angående gravene, og som nå helt uventet var satt i verk. Fremgangsmåten hadde medført beklagelige misforståelser og kunne gi et uriktig inntrykk av nordmenns følelser overfor dem som hadde ofret livet i kampen for Norges frigjøring, hevdet sambandet. De mente det var en æressak for landet å gi de sovjetiske soldatene som mistet livet i Nord-Norge gravplass på norske kirkegårder i nord. ${ }^{320}$ Norsk-Sovjetisk Samband var åpenbart sterkt engasjert i gravsaken og ønsket å bidra i det videre arbeidet med å ivareta gravene.

Forfatter Halvor Fjermeros har i sin siste bok Med lik i lasten. Operasjon Asfalt - de sovjetiske massegravenes skjebne i Norge (2013) intervjuet flere tidsvitner, og blant disse er Borghild Eilertsen og Arnt Olsen fra Mo i Rana. Begge deltok i demonstrasjonene mot flyttingen av gravene i byen. Olsen påpeker at det ikke var noen partipolitisk aksjon, den skjedde nærmest spontant, og det var spesielt de ansatte ved Mofjell Gruber som mobiliserte til demonstrasjonen. Fjermeros fremhever Eilertsen som representant for den mellommenneskelige faktoren han antar utgjorde den avgjørende bakgrunnen for hendelsene i Mo i Rana. ${ }^{321}$ Sympatien for de tidligere fangenes skjebne var sterk og engasje-

319 Verdens Gang, 03.11.1951.

320 Verdens Gang, 05.10.1951.

321 Fjermeros Halvor: Med lik i lasten. Operasjon Asfalt - de sovjetiske massegravenes skjebne i Norge. Spartacus, Oslo 2013: 145-147. 
mentet stort i byen. Det faktumet at de klarte å stoppe de lokale planene i en landsdekkende operasjon, viser hvilken påvirkningskraft befolkningen hadde i Mo i Rana. I sin masteroppgave om opinionens reaksjoner på «Operasjon asfalt», En ualminnelig vemmelig sak, skriver Gaute Lund Rønnebu at reaksjonene knyttet til gravene var sterkere i Mo i Rana enn i Ofoten og Salten. Folk godtok i større grad myndighetenes begrunnelse for oppgravingen andre steder. ${ }^{322}$ Det var åpenbart at myndighetene tok feil av engasjementet til befolkningen i Mo i Rana og deres vilje til å hindre oppgravingen.

Engasjementet knyttet til flyttingen av de sovjetiske gravene var preget av sterke følelser og kritikk av fremgangsmåten. Ved oppgravingen i Mosjøen var folk i byen opprørt over gjennomføringen av arbeidet. 20 lik var gravd opp og lagt i papirsekker, med tre ofre i hver sekk. Et av likene var slengt på en søppelhaug sammen med rester av ammunisjonskasser som var brukt som kister. Klesfiller og beinrester lå om hverandre som uhyggelige vitnesbyrd om det som ble betraktet som en skjendig gjerning. Monumentet som hadde stått på gravstedet, var sprengt i filler. Folk i Mosjøen mintes at dette hadde vært et vakkert anlegg og var svært opprørt over denne «taktløsheten og forakten for jordiske levninger av de lidende venner som fant sin hvile i norsk jord». ${ }^{323}$ Dette skjedde til tross for at statssekretær Jens Boyesen i Utenriksdepartementet hadde sagt at det var gitt ordre om at minnesmerkene skulle bevares. ${ }^{324}$ Ved en gravplass i Narvik-området ble levningene av sovjetiske krigsfanger fraktet bort i papirsekker mens korsene og navneplatene med innskrift ble veltet og lempet i en haug. ${ }^{325}$ I disse tilfellene ble det åpenbart ikke gitt instrukser om at minnesmerkene skulle tas vare på.

I et innlegg i Nordlands Folkeblad ble behandlingen av de sovjetiske gravene i Mosjøen beskrevet som forakt for de falnes graver. På gravplassen ved kapellet i Mosjøen lå det gravlagt 28 sovjetiske krigsfanger som presten hadde lyst fred over som ofre for nazismen. I innlegget ble det opplyst om at man nå var ferdig med oppgravingen, og at den hadde blitt utført av én mann uten offentlig tilsyn. Han hadde gravd opp levningene og kastet tre lik i hver sekk for videre transport til Tjøtta. Oppgravingen ble beskrevet som en skam for vårt land og et svik mot vårt folk, og en forakt mot gravfreden og de demokratiske idealene. Innlegget var nektet tatt inn i Helgeland Arbeiderblad. På

322 Rønnebu Lund, Gaute: En ualminnelig vemmelig sak. Opinionens reaksjoner på Operasjon Asfalt i 1951. Masteroppgave i historie. Universitetet i Nordland. Våren 2014: 99.

323 Nordland Arbeiderblad, 09.10.1951.

324 Nordlands Folkeblad, 28.09.1951.

325 AVPRF, f.07, op.26,p. 47, d. 141, II. 1-4. «Utenriksministeriets verbalnote til Norges ambassade i USSR om flytting av sovjetiske krigsgraver i Norge, 1. oktober 1951». Original oversatt av Sven G. Holtsmark, Norge og Sovjetunionen 1917-1955. Institutt for forsvarsstudier og Det russiske vitenskapsakademi, Oslo 1995: 460-461. 
samme side i Nordlands Folkeblad ble innsenderen av innlegget beskyldt for politisk propaganda. Her ble det hevdet at en av stedets kommunister på en taktløs måte hadde forsøkt å utnytte folks sympati overfor de døde til politisk propaganda. Han mente at flertallet av befolkningen hadde stor respekt for døden og gravfreden. Han viste til at det trolig var mange, også ikke-kommunister, som ikke samtykket i flyttingen av krigsfangegravene, men at kritikk mot den under ingen omstendighet måtte utarte seg til usømmelighet og utnyttes til politisk propaganda. ${ }^{326}$ Begge innleggene viser engasjementet hos befolkningen angående flyttingen av gravene i dette området. Noen dager senere hadde førstnevnte et nytt innlegg i samme avis under tittelen «Hva med gravskjenderiet», hvor han kritiserte kirkens representanter for ikke å ta ansvar for hva som foregikk på kirkegården. Han stilte spørsmål til hvorfor det plutselig var så hastverk med å få flyttet de døde russerne til Tjøtta, og han var veldig kritisk til kostnadene omkring flyttingen av ofrene. Til slutt ble flyttingen beskrevet som en nedverdigelse og skam som manglet sidestykke i Norges historie. ${ }^{327}$ På samme side i avisen var det også et innlegg med tittelen «Gravskjendingen». Innlegget viste til en veldig skarp lederartikkel i Arbeider-Avisa med følgende tekst:

Det skulle være en selvfølgelig sak, en nasjonal æressak for det norske folk å hegne vel om alle gravene til våre allierte og de minnesmerker som er reist. Det er derfor så beskjemmende og uhyggelig å lese om den vanvyrdnad som er vist overfor de russiske gravene, bla i Mosjøen og ved Narvik, der minnesmerke og minnetavler er ødelagt og likene av oppgravde russere er behandlet med en opprørende usømmelighet - et par lik eller rester av lik skal f. eks være funnet på søppelhaugen. Vi kan forstå at det flere steder kan være ønskelig å flytte de russiske gravene, men ingenting unnskylder den måten dette delvis er gjort på. ${ }^{328}$

I et svar på denne anklagen sendte Politimesteren i Helgeland en rapport til Oslo politikammer i oktober 1951 om oppgravingene i Mosjøen. I rapporten ble det opplyst at 28 lik av russere var gravd opp. Likene som under krigen var gravlagt på ulike steder i Mosjøen, ble av norske militærmyndigheter gravd opp og lagt i kister og ammunisjonskasser, og nedsatt i en grav på kirkegården. Graveren fortalte at under oppgravingsarbeidet viste det seg at to lik og delvis et tredje lå under fundamentet på gravstøtten, som var meget stor. Under gravingen hadde den begynt å sige, og det var ikke mulig å få likene frem med mindre støtten ble fjernet. På grunn av størrelsen så han ingen mulighet til å

326 Nordlands Folkeblad, 21.09.1951.

327 Nordlands Folkeblad, 05.10.1951.

328 Ibid. 
få fjernet gravstøtten like hel. Han hadde derfor slått den i stykker med slegge og dels brukt små dynamittladninger. Han ble nødt til å brenne et av likene. Dette ble fraktet til en skråning ved elven og tildekket med ammunisjonskasser og likkister. Hodeskallen hadde han lagt i en sekk sammen med andre lik. Siden han ikke fikk tak i parafin, ble liket liggende et par dager og deretter brent. Restene ble lagt i en spesialsekk og overlatt til militæret. Politimesteren fremhevet i sin rapport at mannen hadde vært graver i mange år, og at han selv hevdet bestemt at han hadde vist den hensynsfullheten og pieteten som arbeidet krevde ved denne anledning som ellers. Graveren avviste bestemt enhver bebreidelse over den måten arbeidet var utført på og benektet at lik var partert. Han benektet dessuten å ha uttalt: «Disse simple russere skulle vært fjernet til et öde sted for lenge siden.» ${ }^{329}$

Graveren påstod at det var foretatt en ordinær likoppgraving, og at det var nødvendig å fjerne gravstøtten for å få arbeidet gjennomført. Politimesteren så ingen grunn til å bebreide graveren for måten arbeidet var gjennomført på. Likevel påpekte han at graveren burde så raskt som mulig ha brent de likene som fremdeles hadde kjøttrester. Hva angikk gravstøtten, anså politimesteren det for uoverkommelig arbeid å flytte den uten at den ble ødelagt. Til slutt fremhevet politimesteren at det var utelukket at graveren bevisst hadde vist mangel på pietet.

I Troms utviklet protestene seg til farlige handlinger. Om lag 150-200 lik var samlet fra fire-fem gravplasser og plassert i et naust som lå omtrent midt i bygda i Skibotn. Fra Øvergård i Balsfjord var det gravd opp 90 lik samt ett fra kirkegården på Vollan. Alle disse var ført til Skibotn, og man antok at det var lagret om lag 670 lik der. Det var ventet et skip fra Finnmark som skulle hente likene og transportere dem til Tjøtta. Skipet skulle etter opplysningene fra kaptein Overdale frakte 4000 lik fra Sør-Varanger, og var forsinket. På dette tidspunktet var gravene i Kvænangen og Nordreisa ikke tatt opp. I Øverbygd og Målselv var det tatt opp ca. 230 gravlagte krigsfanger. Kaptein Overdale rapporterte til Forsvarsdepartementet om forholdene ved oppgravingen i Skibotn i Troms. En episode i Skibotn kunne raskt ha fått svært alvorlige følger. En granat ble hengt opp i et bjørketre for å stanse oppgravingen i Øverbygd. Dette skjedde under oppgravingen av to massegraver som inneholdt 160 lik. Da oppgravingsmannskapene kom om morgenen, oppdaget de granaten. Tennmekanismen var festet i en streng som var plassert slik at de som skulle arbeide med gravene, lett kunne kommet borti den. Militæret i området konstaterte at dette var en granat som var tatt fra deres lager. Lensmannen i Målselv ble kontaktet angående håndgranaten, og det viste seg at den var

329 RA, Krigsgravtjenesten, eske 26-35. Notat. Oslo politikammer. Oslo 12.10.1951. 
hengt opp om natten og utvilsomt $\mathrm{i}$ anledning oppgravingen. ${ }^{330}$ Det ble ikke oppgitt hvem de skyldige var.

Politiet i Tromsø fryktet demonstrasjoner i byen. Etter et møte med politimesteren i Tromsø, stabssjefen ved Sjøforsvaret i Nord-Norge og sjefen på Skattøra sjøflyhavn ble det lagt frem en plan for oppgravingen på Tromsø kirkegård. De to hovedportene til kirkegården skulles stenges. Ved fire resterende porter skulle det stå sivile politifolk som holdt et øye med situasjonen. En utrykningsstyrke skulle stå klar på politikammeret for aksjon hvis det ble nødvendig. De oppgravde likene skulle legges direkte på lastebiler på kirkegården og kjøres til Skattøra flystasjon. D/S «Raftsund» skulle dirigeres til Skattøra, hvor mottakelsen av lasten ble ledet av stasjonssjefen, kaptein Anonsen. Det var viktig at det også her ble satt vakt ved porten. Etter innlasting skulle skipet fortsette til Tomasjord brygge, hvor likene fra Tromsdalen kirkegård skulle lastes om bord. Operasjonen på Tomasjord skulle foretas etter samme retningslinjer som på Skattøra. Overdale påpekte at Tomasjord brygge lå på militært område og var disponert av Skattøra flystasjon. ${ }^{331}$ Det var tydelig at Forsvarsdepartementet ønsket å bruke militære områder under operasjonen, og at de var villige til å bruke politiet som maktmiddel ved eventuelle demonstrasjoner eller uro fra befolkningens side. Ved å bruke militært område ble også risikoen for å vekke negativ oppmerksomhet redusert.

Oppgravingen skapte sterke reaksjoner blant befolkningen i Tromsø, og mange stilte opp på kirkegården i håp om å få arbeidet innstilt. I bladet Tromsø ble det rapportert fra oppgravingene i byen:

Massegravene i Tromsø gravd opp i går. De döde vist militær honnör på Skattöra. Etter ordre fra departementet ble i går de 15-16 russiske soldatgraver på kirkegården i Tromsö satt i verk. De döde lå i simple trekasser på bare knapt en meters dybde. Da det tidligere hadde vært tillöp til en viss uro i forbindelse med oppgravingen av russerne på Tromsö gravlund var to sivilkledde politimenn til stede. Deres oppgave var å sikre at kirkegårdsfreden ikke ble krenket. Noen tilskuere innfant seg, og de tok noen fotografier. De jordiske restene av de russiske soldatene ble först lagt i særskilte, store papirposer og senere overfört til trekister. Trekorsene på deres graver ble også tatt vare på. Kistene ble overfört til Skattöra, der en viste de döde militær honnör i form av «vakt i gevær» og flagget på halv stang, gjentar og flaggene vaiet på halv stang. På Skattöra ble kistene overfört til et særskilt skip som skal forestå den videre transport. ${ }^{332}$

330 RA, Krigsgravtjenesten, eske 26-35. Melding fra kaptein Overdale. Tromsø 12.10.1951.

331 RA, Krigsgravtjenesten, eske 26-35. Melding fra Tromsö den 18.10.1951.

332 RA, Krigsgravtjenesten, eske 26-35. «Skriv mottatt fra Tromsö den 24.10.1951». 
To menn blant graverne forsvant fra oppgravingen fordi det ble tatt bilder under arbeidet, men ellers ble operasjonen gjennomført etter planen i Tromsø. Kaptein Overdale meldte også at operasjonen ble gjennomført uten noe uro i Tromsdalen.

I avisen Nordland Arbeiderblad kunne man lese at meddelelsen om ødeleggelsen av den sovjetiske kirkegården i Tromsø skapte sterk bitterhet blant byens arbeiderbefolkning. ${ }^{333}$ Politimesteren i Tromsø rapporterte i oktober at flere kommunister hadde møtt opp under oppgravingen på Tromsø gravlund. De hadde snakket med arbeiderne som hadde startet med oppgravingen og spurt dem hvordan de likte arbeidet. Senere hadde de fremmøtte kommet med ukvemsord mot arbeiderne og henstilt dem om å slutte med oppgravingen. På grunn av dette ble arbeidet avsluttet, og det som var oppgravd, ble gravd ned igjen. I løpet av dagen ble det satt opp to plakater i Tromsø. Den ene hadde påskriften: «Skjendingen av de russiske krigsgravene er begynt og pågår i Tromsö. Möt fram på Gravlund og stopp vandalismen.» På den andre plakaten stod det: «Minnemøte i dag kl. 1800 på gravlund.» Senere på kvelden møtte 15 personer frem på gravlunden for å legge ned krans på gravene. Politimesteren rapporterte at de fremmøtte - som han kommenterte som et ubetydelig antall personer (15) - var kommunister. Graveren ved Tromsø gravlund ble kontaktet av politiet og kunne fortelle at han ikke var informert om at oppgravingen skulle gjennomføres. Han hadde først fått kjennskap til saken da arbeidslederen for arbeiderne møtte opp på hans kontor og ba om anvisning på hvor de sovjetiske gravene var plassert. ${ }^{334}$ På minnemøtet hadde bygningsarbeider Einar Ravnbø holdt en tale, og han minnet om hvilken del de døde hadde i Norges frigjøringskamp og uttrykte et ønske om at krigsgravene i Tromsø skulle bli spart for de ødeleggelsene som ble satt i verk. ${ }^{335}$

Kaptein Overdale hevdet at det neppe var mulig å unngå demonstrasjoner fra kommunister når oppgravingen fortsatte i Tromsø, men han hadde ikke tro på at det skulle bli alvorlige demonstrasjoner. ${ }^{336}$ Protestene fra kommunistene resulterte $i$ at arbeidet ble utsatt i to uker, men likene ble til slutt tatt opp. Etter hendelsene i Tromsø ble Forsvarsdepartementet mer oppmerksom på at man skulle innskjerpe en mer pietetsfull fremgangsmåte. Departementet var nå opptatt av at ingen monumenter eller gravsteiner skulle ødelegges. Dersom gravsteiner måtte flyttes, skulle de tas vare på. Oppgravingene i Tromsø ble til slutt gjennomført den 23. oktober 1951. Politiet stilte to vakter i sivil på kirkegården, og beredskapsstyrken stod klar på politikammeret i tilfelle det

333 Nordland Arbeiderblad, 09.10.1951.

334 RA, Krigsgravtjenesten, eske 26-35. «Notat ang. oppgraving av 16 russergraver i Tromsö». Oslo 06.10.1951.

335 Nordland Arbeiderblad, 09.10.1951.

336 RA, Krigsgravtjenesten, eske 26-35. «Skriv mottatt fra Tromsø 09.10.1951». 
skulle oppstå problemer under arbeidet. Pressen ble informert av politimesteren morgenen samme dag som oppgravingene startet. To av byens gravere gjennomførte oppgravingen og gjenkastingen av gravene. Korsene som stod på gravene, ble plassert i kapellet. Fem fremtredende kommunister i Tromsø demonstrerte i om lag en time under oppgravingen og tok en del bilder. Da oppgravingen var ferdig, ble de 17 sovjetiske ofrene på kirkegården i Tromsø transportert i kister til Skattøra flystasjon og tatt om bord i D/S «Raftsund» under militær honnør. I Tromsdalen ble fire ofre gravd opp uten protester fra lokalbefolkningen. Også disse ofrene ble fraktet om bord i D/S «Raftsund», men uten noen seremoni. Dagen etter, da arbeidet var gjennomført i Tromsø og Tromsdalen, ga lensmannen i Balsfjord beskjed om at to kjevebein lå igjen på russergravstedet i Øvergård, og disse ble hentet samme dag. ${ }^{337}$

Protestene og reaksjonene vitner om det sterke lokale engasjementet og minnet knyttet til krigsfangenes skjebne. Men hendelsene viser også at myndighetene ikke lot seg påvirke i særlig grad av lokalbefolkningens reaksjoner.

\subsection{Sovjetiske reaksjoner}

Det ble også protestert heftig fra sovjetiske myndigheter mot flyttingen av gravene. I sovjetiske aviser markerte man sin motstand, og den sovjetiske ambassaden rettet skarp kritikk mot norske myndigheters håndtering av gravsaken.

Etter at monumentene var ødelagt, hevdet norske myndigheter at det $\mathrm{i}$ instruksene for gjennomføringen av flyttingen, var uttrykkelig sagt at minnestøttene skulle bevares. Det ble imidlertid påpekt at gravplassen ved Skafferhullet ved Elvenes var et unntak. Hele gravområdet her var dekket av en betongplatting. Plattingen måtte fjernes før en kunne flytte de gravlagte. Oppå plattingen stod et primitivt minnesmerke av betong som var sterkt forfallent. Dette ble fjernet. Anlegget ble fotografert før plattingen og minnesmerket ble fjernet. Det ble ellers uttalt at en rekke minnesmerker var i så dårlig forfatning at de måtte fjernes og nye settes opp. I et notat ble det også vist til følgende uttalelse fra den sovjetiske ambassaden i avisen Friheten den 8. september 1951:

Ambassaden har ikke fått noen underretning fra de norske myndigheter om at det foregår oppgravning av de jordiske levninger etter sovjetborgere som er begravet på norsk territorium. ${ }^{338}$

337 NHM, 278. Krigsgravtjenesten, dokumentsamling. Rapport fra kaptein O. B. Overdale. Oslo 08.11.1951.

338 RA, Krigsgravtjenesten, eske 26-35. Notat, Utenriksdepartementet Oslo 08.09.1951. 
Fra norsk side ble det hevdet at denne opplysningen var direkte i strid med de faktiske forholdene. Kort tid før informerte Utenriksdepartementet den sovjetiske ambassaden om at den norske regjeringen hadde godkjent planen for samlingen av de sovjetiske krigsgravene i Norge, og at arbeidet med flyttingen av gravene ville starte noen dager etterpå. 339

Ifølge sovjetiske myndigheter var minnesmerkene ved Skafferhullet (Elvenes), Bodø, Mosjøen, Skibotn, Kitdalen og Øvergård sprengt eller ødelagt. ${ }^{340}$ Monumentene ved Skafferhullet, i Bodø og i Mosjøen ble sprengt fordi gravene var plassert rett under monumentene. Krigsgravtjenesten opplyste at monumentet ved Skafferhullet bestod av sement og netting som var fylt med jord. På grunn av frost og fukt hadde det fått noen større revner. Betongplattingen som monumentet var plassert på, ble i sin tid anlagt midt på gravfeltet. Under oppgravingen viste det seg at flere lik lå under monumentet. Under arbeidet med oppgravingen ble revnene på monumentet noe større. Av sikkerhetsmessige årsaker ble det nødvendig å ta ned monumentet. Monumentene i Bodø og Mosjøen var tatt ned fordi de var støpt over de gravlagte. ${ }^{341}$ Det ble ikke nevnt her at monumentene ble sprengt. Den vesle minnesteinen på Elvenes var enten slått eller sprengt i stykker samtidig med at de nærmere 400 gravene var gravd opp. I avisen Nordland Arbeiderblad ble det ødelagte monumentet beskrevet som resultatet av et offisielt anerkjent hærverk. ${ }^{342}$

Reaksjonene fra sovjetisk side var ikke til å ta feil av, og det ble lagt vekt på å få frem hastverket ved operasjonen og den sterke misnøyen fra befolkningens side. Det norske Forsvaret var opptatt av å argumentere for hvorfor monumentene ble ødelagt. Russerne avviste norske myndigheters erklæring om at monumenter til ære for de falne sovjetsoldater ikke ble ødelagt, og hevdet at ødeleggelsen fortsatte med flyttingen av krigsgravene. I et telegram ble det vist til at monumentet på Ravndalsvollen i Nordland ble sprengt den 5. oktober. ${ }^{343}$ Kaptein Ove Bang Overdale fra Forsvarsdepartementet meldte tilbake at de var ukjent med stedsnavnet Ravndalsvollen. De hadde undersøkt i post, telegraf, telefonregistre og ved samtlige politikontor fra Bodø til Kirkenes, men ikke funnet noe informasjon om dette stedet. ${ }^{344}$ Dagen etter ble det oppklart og kaptein Arntzen fra Krigsgravtjenesten meldte at Ravndalsvollen (Randalsvollen) var identisk med Bolna i Nord-Rana. Monumentet ved Randalsvollen ble sprengt. Arntzen oppga at han hadde rapportert om sprengningen tidligere til Forsvarsdepartementet. Monumentet var laget av jord og murstein med

339 Ibid.

340 RA, Krigsgravtjenesten, eske 26-35. Notat til statsråden. Oslo 02.11.1951.

341 RA, Krigsgravtjenesten, eske 26-35. Oversikt. «Operasjon asfalt». Ikke datert.

342 Nordland Arbeiderblad, 02.10.1951.

343 RA, Krigsgravtjenesten, eske 26-35. Telegram, Moskva 17.10.1951.

344 RA, Krigsgravtjenesten, eske 26-35. «Skriv mottatt fra Tromsø den 19.10.1951». 
en hel inskripsjon som oppga at her hviler russiske krigsfanger. Begrunnelsen for sprengningen var at monumentet dekket hele graven og at sprengning var nødvendig for å grave opp ofrene. Restene av det sprengte monumentet ble liggende på stedet, og inskripsjonen ble ikke bevart. Arntzen hevdet at monumentet var i dårlig forfatning før sprengningen ble foretatt. ${ }^{345}$

Ved Kitdalen i Skibotn var gravene markert med trekors da oppgravingen startet. Korsene var ifølge Arntzen i en slik forfatning at det ikke var noen grunn til å oppbevare disse. Han påpekte at det ikke var snakk om noen tilintetgjørelse av sovjetiske graver, og at norske myndigheter var villige til å reise minnesmerker på de tidligere gravstedene. I notatet til statsråden angående den sovjetiske verbalnoten 31. oktober 1951 om sovjetiske krigsgraver i Norge, ble spørsmålene om minnestøttene drøftet. Her ble det lagt vekt på at siden den sovjetiske regjeringen ikke var villig til å samarbeide med norske myndigheter angående utformingen av gravplassen på Tjøtta, burde man kanskje ta opp spørsmålet om å la russerne uttale seg om utformingen av minnestøttene som skulle settes opp på de tidligere gravstedene. ${ }^{346}$

Norske myndigheter beklaget at den sovjetiske regjeringen hadde mistillit til den norske regjeringen i behandlingen av flyttingen av gravene til Tjøtta. De mente at det var et sterkt ønske fra den norske befolkningen å få til en verdig bevaring av minnet om de sovjetiske krigsfangene som døde i Norge. Når planen for det nye gravanlegget på Tjøtta var gjennomført, ville de som døde i Nord-Norge for alltid være sikret et vakkert siste hvilested, ifølge regjeringen. Ifølge norske myndigheter var den sovjetiske mistilliten forårsaket av utilstrekkelig informasjon. For å rette på dette ble det vedlagt et memorandum som inneholdt opplysninger angående flyttingen av graver fra de stedene som var nevnt i verbalnoten av 31. oktober. På dette tidspunktet var transportene fra de tre fylkene i Nord-Norge avsluttet, og det var ønskelig at gravanlegget på Tjøtta fikk en utforming som var tilfredsstillende for både sovjetiske og norske myndigheter. Når det gjaldt de øvrige planene for samling av sovjetiske graver i Norge, var norske myndigheter villige til å utsette planen til saken hadde vært ordentlig drøftet av representanter for Norges og Sovjetunionens regjeringer. På denne måten håpet den norske regjeringen å unngå de ubehagelige uoverensstemmelsene som denne saken hadde medført. ${ }^{347}$

I en notis i Nordland Arbeiderblad i juni 1951 ble det hevdet at norske myndigheters behandling av så vel tyske som sovjetiske krigsgraver i Norge hadde vakt pinlig oppmerksomhet i verden. Etter at en tysk forening i München hadde protestert mot at de tyske krigsgravene på Ekeberg ved Oslo ble van-

\footnotetext{
345 RA, Krigsgravtjenesten, eske 26-35. «Skriv mottatt fra Tromsø den 20.10.1951».

346 RA, Krigsgravtjenesten, eske 26-35. Notat til statsråden. Oslo 02.11.1951.

347 RA, Krigsgravtjenesten, eske 26-35. Notat, Boyesen. Udatert.
} 
skjøttet, hadde den sovjetiske avisen Isvestija i Moskva skrevet om de sovjetiske krigsgravene i Norge. Avisen trykte en lengre artikkel om flyttingen av gravene. Norske myndigheter ble kritisert for å gjennomføre flyttingen i et raskt tempo og på en ytterst skjødesløs måte. Likrestene ble samlet i papirsekker og stablet inn i noen skur, skrev avisen. Artikkelforfatteren M. Stefanov skriver videre at:

Det ser ut til at noen gravplasser i Finnmark og Troms for sovjetsoldater som falt i kampene for Norges frigjøring er en torn i øyet på de norske myndighetene, som ønsker å tilintetgjøre minnet om det norske folks befriere. Disse myndigheter synes å ha besluttet at alle rester av sovjetsoldater skal føres bort fra gravplassene i Troms og Finnmark og flyttes over på den isolerte øya Tjøtta. Etter dette barbariske vedtaket satte man i gang oppgravningen av sovjetsoldatenes lik. Den kaptein i det norske forsvarsdepartement som leder arbeidene har uttalt at alle spor etter gravplassene skal utslettes fullstendig, gravplater og steiner skal fjernes. Arbeidet utføres i stor hast og i all hemmelighet, for at ikke befolkningen skal få vite noe før gravplassene og minnesmerkene er tilintetgjort. En kan ikke betegne de norske myndigheters opptreden som noe annet enn en hån mot minnet om sovjetsoldatene som falt i kampen om Norges frigjøring. ${ }^{348}$

På grunnlag av ordlyden i artikkelen kan det se ut som om artikkelforfatteren har hatt en oppfatning av at flyttingen kun dreide seg om graver etter soldater som falt i kamp i Finnmark høsten 1944, og ikke graver etter sovjetiske statsborgere som satt i tysk fangenskap i Nord-Norge.

Norske myndigheter var opptatt av at flyttingen av de sovjetiske gravene ble kritisert i avisen Isvestija. Kaptein Syvertsen ved Sentralkontoret for krigsgraver mente at fremstillingen i avisen ikke var riktig. Man måtte huske på at den alt overveiende delen av ofrene var krigsfanger som døde i løpet av krigen, og som ble gravlagt av tyskerne. I svært mange tilfeller var de sovjetiske ofrene gravlagt i ulltepper eller presenninger og ikke i kister. Disse teppene og presenningene måtte man av helsemessige årsaker brenne ved oppgravingen. Det hadde ifølge kapteinen ikke vært snakk om å brenne likrester. For å unngå epidemier hadde det blitt brukt sprit for å få teppene til å brenne ordentlig. Kapteinen påpekte at de helsemessige hensynene hadde kommet i første rekke, og at oppgravingen av alle ofrene hadde foregått så verdig som mulig. Årsaken til at ofrene først ble oppbevart i skur, var ifølge kapteinen nødvendig fordi man ikke kunne frakte likene for langt eller finne oppbevaringssteder i tettbebyggelse. Det var den samme arbeidsgjengen som hadde foretatt oppgravingene overalt, og de hadde gått frem etter forskrifter som tok hensyn til både de helsemessige og

348 Artikkelen fra avisen Isvestija er sitert i avisen Nordland Arbeiderblad juni (udatert) 1951. 
estetiske kravene. Når det gjaldt uttalelsene i Isvestija om at dette dreide seg om graver etter soldater som falt i frigjøringskampen, var dette en sannhet med sterke modifikasjoner, ifølge Syvertsen. Det var russerne selv som etter kampene hadde tatt vare på sine falne, og man hadde ikke tall på hvor mange det var som hadde falt i kamp på norsk territorium. ${ }^{349}$

I november 1951 fikk sognepresten i Bodin sogneprestembete (Nordland) besøk av en representant fra den sovjetiske ambassaden. Sognepresten fikk vite at gjesten het Igonin, men han legitimerte seg ikke. Igonin ønsket å vite hvor mange sovjetiske graver som var gravd opp og om minnesmerker var sprengt bort. Sognepresten fortalte at 32 navnløse sovjetiske graver var gravd opp, og at flesteparten av likene ikke lå i kister. Utenfor kirkegården var det samlet 18 graver fra ulike steder, og her var et minnesmerke fjernet for å kunne komme til med oppgravingen. Igonin ville vite hva sognepresten mente om oppgravingen og om folk syntes det var merkelig med all denne oppgravingen. Sognepresten hadde stusset over disse spørsmålene siden en utlending neppe ville få anledning til å stille en sovjetisk embetsmann lignende spørsmål. Likevel valgte sognepresten å svare. Han viste til at det var ikke bare sovjetiske graver fra krigstiden som var samlet. Dette var også gjort med tyske, engelske, franske og polske graver. Igonin påpekte at andre graver fra krigstiden ikke var samlet bare på et eneste sted, slik det nå ble gjort med de sovjetiske gravene. Sognepresten henviste til at noen av gravstedene lå innenfor militært område, og derfor var det rimelig at gravene ble samlet. Med hensyn til hva folket mente, svarte sognepresten at de var vant til slik oppgraving, og han trodde ikke noen syntes det var så merkelig. Etter at krigshandlingene var slutt i Nord-Norge i 1940, ble nesten 50 trøndere som var gravlagt i Gratangen, gravd opp og sendt til hjemstedet. Dessuten var sognepresten på samme tid involvert i arbeidet med oppgraving og hjemsending av en belgisk statsborger. Sognepresten fortalte også at Bodin menighetsråd og herredsstyre i 1949 hadde tatt på seg vedlikeholdet av russergravene og minnesmerket like utenfor Bodin kirkegård, men hadde etter kort tid fått beskjed om at russerne selv skulle sørge for vedlikeholdet. Dette hadde imidlertid vært dårlig, eller rettere sagt hadde det ikke vært noe vedlikehold, ifølge sognepresten. Høsten 1951 hadde han grepet inn for å få pyntet litt opp ved minnesmerket. Til slutt oppga sognepresten at han hadde vært til stede i lengre tid under oppgravingen og kunne forsikre om at den foregikk på en sømmelig måte og at alle rester var omhyggelig tatt vare på fra hver eneste grav. ${ }^{350}$ Det kommer tydelig frem i brevet fra sognepresten at han syntes dette besøket var merkelig, og han tilføyde også at sognepresten i Bodø hadde hatt

349 Helgeland, 18.09.1951.

350 RA, Krigsgravtjenesten, eske 26-35. «Ad oppgravingen av russiske krigsgraver». Bodø 02.11.1951. 
besøk av representanten fra ambassaden senere samme dag, og at han da hadde fortalt at han var utsending for det sovjetiske telegrambyrået Tass.

Sovjetregjeringen hevdet at den norske regjeringen prøvde å dekke over en uberettiget tilintetgjørelse av gravene og gravsamlingene til sovjetiske soldater og krigsfanger i Norge, med falske og hyklerske henvisninger til at disse handlingene angivelig var diktert av den norske regjeringens omsorg for vedlikehold av gravene. Fra sovjetisk side ble det hevdet at den norske regjeringen brukte vedlikehold av graver som påskudd for å frata det norske folket muligheten til å ære minnet om de sovjetiske soldatene som bukket under i kampen mot tyske okkupanter i Norge. Fra sovjetisk side anså man flyttingen av gravene for å være en uvennlig handling, og de insisterte på at tilintetgjørelsen av de sovjetiske krigsgravene i Nord-Norge straks skulle opphøre. Norske myndigheter avviste at flyttingen av gravene var en utslettelse av kirkegårder. De påpekte at dette ikke dreide seg om sovjetiske soldater som falt i krig på norsk territorium, men om sovjetiske krigsfanger. Norske myndigheter ville reise minnesmerker på de stedene hvor det hadde vært gravlagt flere sovjetiske krigsfanger. På denne måten mente de det ville være mulighet for den norske befolkningen å ære minnet om de sovjetiske soldatene som døde i kampen mot de tysk-fascistiske okkupantene i Norge. ${ }^{351}$

Kommunistenes avis Friheten gjenga i begynnelsen av oktober 1951 en artikkel skrevet av M. Balikov med tittelen «Jeg kan ikke tie! Hvorfor ødelegges de russiske krigsgraver?». ${ }^{352}$ Balikov hadde deltatt i frigjøringen av Øst-Finnmark. Han skrev at tusener av sovjetiske soldater ofret livet for det norske folkets frihet, men uten å bry seg om de falne soldatenes ære og det norske folkets samvittighet hadde norske myndigheter tatt fatt på oppgravingen og utslettelsen av soldatenes graver. Balikov mintes hvor hardt de sovjetiske soldatene kjempet mot tyskerne i Norge, og hvor varmt og inderlig de ble tatt imot av nordmennene. Hvis nordmenn fant likene av sovjetiske flygere, hjalp de til med å begrave dem, selv om de visste at det var dødsstraff for dette. Han skrev at de ofte ble rørt over nordmennenes vennlighet og gjestfrihet. Minnesmerker som var satt opp av takknemlige nordmenn, ble sprengt, og alle spor etter gravene og kirkegårdene ble fjernet. Balikov følte at det var vanskelig å tie når han leste meldingene $\mathrm{i}$ avisene om den barbariske måten gravene ble ødelagt på. ${ }^{353}$

I Verdens Gang ble det skrevet om «leserprotester i Moskva-avisene mot flyttingen av soldatgravene i Norge». Pressen i Moskva hadde offentliggjort flere brev fra sovjetiske borgere som protesterte mot flyttingen av sovjetiske krigsgraver i Norge. Bygningsarbeideren Ivan Sidnin skrev i et brev til avisen Pravda at folket hadde med harme og vrede mottatt meldingene om at de

351 RA, Krigsgravtjenesten, eske 26-35. Notat til statsråden. Oslo 02.11.1951.

352 Friheten, 08.10.1951.

353 Ibid. 
norske myndighetene hadde ødelagt gravene til de sovjetsoldatene som hadde ofret livet for å frigjøre Norge fra Hitler-Tyskland. Han skrev:

De sprenger monumentene og gravplatene og utsletter alle spor etter gravene og kirkegårdene. Bare samvittighetsløse mennesker kan begå slike handlinger. Sammen med hele sovjet-folket fordømmer jeg de norske myndigheters handlinger og krever at de inntar en verdig holdning overfor minnene til min sønn og alle soldater i sovjet-hæren som falt for Norges frigjøring. ${ }^{354}$

To sovjetiske journalister fra telegrambyrået Tass rapporterte fra oppgravingen i Nord-Norge. I et skriv merket «strengt hemmelig» viste politiinspektør Asbjørn Bryhn til en melding fra journalistene som ble kunngjort via Moskva radio. I meldingen ble det hevdet at de sovjetiske krigsgravene i Alta-området ble fullstendig ødelagt allerede i slutten av juli eller begynnelsen av august 1951. Alle lik var tatt opp og sendt bort, gravstøttene ble ødelagt og gravene jevnet med jorden. Det ble gjort alt for å fjerne alle tegn etter krigsgravene. Sivile og kirkelige myndigheter var ikke orientert om arbeidet med å tilintetgjøre soldatenes graver. Til slutt ble det hevdet at de tyske okkupantenes graver ikke ble ført noen steder i Nord-Norge, mens sovjetsoldatenes graver ble ødelagt. ${ }^{355}$ Dagen etter ble det hevdet i Moskva-avisene at ødeleggelsene av de sovjetiske krigsgravene fortsatte i Nord-Norge, til tross for den offisielle kunngjøringen om at den var stoppet. Det ble også skrevet at ødeleggelsene av monumentene foregikk samtidig med ødeleggelsene av gravene. ${ }^{356}$

Den norske regjeringen hadde tidligere overfor Sovjetunionens ambassade gitt uttrykk for beklagelse over at vedlikeholdet av de sovjetiske borgeres graver i Norge i mange tilfeller ikke hadde vært tilfredsstillende. Utenriksdepartementet påpekte at gravenes antall var meget stort, og at de lå spredt over hele landet, til dels på utilgjengelige steder hvor man store deler av året knapt hadde noen adkomst i det hele tatt.

Den sovjetiske regjeringen var ikke tilfreds med den norske regjeringens svar på deres note av 31. oktober 1951:

(...) angående de norske myndigheters handlinger med hensyn til graver og gravsamlinger til sovjetiske soldater som er falt for Norges frigjøring fra de tyskfascistiske okkupanter, fordi de nevnte handlinger etter sin karakter krenket minnet om de sovjetiske soldater som falt i kampen mot okkupantene. ${ }^{357}$

354 Verdens Gang, 05.10.1951.

355 RA, Krigsgravtjenesten, eske 26-35. «Skriv mottatt fra Tromsø den 17.10.1951».

356 RA, Krigsgravtjenesten, eske 26-35. «Skriv mottatt fra Tromsø den 18.10.1951».

357 RA, Krigsgravtjenesten, eske 26-35. «Sovjetiske krigsgraver 1946-1952». Avskrift av telegram, fra Moskva 07.12.1951, til forsvarsdepartementet mottatt samme dag. 
Da arbeidet med gravsamlingen etter hvert ble avsluttet, uttalte den sovjetiske regjeringen at «(...) utslettelsen av de sovjetiske borgeres graver i Nordnorge for tiden er stoppet». ${ }^{358}$ Etter statsråd på slottet i november 1951 drøftet regjeringen situasjonen som var oppstått etter Sovjetunionens note i gravsaken. Det ble gitt uttrykk for at planlagte oppgravinger som ikke var påbegynt, burde stoppes foreløpig, uten at det var nødvendig å informere sovjetiske representanter om dette. Arbeid som var startet, skulle likevel fullføres. Kaptein Syvertsen forklarte at det hele hadde gått meget bra på Tjøtta. De fangene som var navngitt, var samlet for seg og gravlagt individuelt. De øvrige var lagt i en fellesgrav. I løpet av et par dager ville alle kjente sovjetiske lik i Nord-Norge være gravlagt på Tjøtta og operasjonen ville da være hundre prosent gjennomført. ${ }^{359}$ Etter at «Operasjon asfalt» var ferdig, var sovjetiske myndigheter opptatt av å drøfte arbeidet med vedlikehold av gjenværende graver og etablering av nye minnesmerker. Norske myndigheter ønsket å unngå besøk av sovjetiske representanter i dette arbeidet.

359 RA, Krigsgravtjenesten, eske 26-35. «Gravsakens stilling torsdag 1. november 1951». Oslo 01.11.1951. 


\section{Den norsk-sovjetiske gravkommisjonen}

Den norske regjeringen sluttet opp om et forslag fra den sovjetiske regjeringen om å oppnevne en blandet norsk-sovjetisk kommisjon for behørig istandsettelse av graver og gravsamlinger til sovjetiske borgere som falt i kampen mot «Hitler-okkupantene» på norsk jord. ${ }^{360}$ Fra sovjetisk side anså de nå at den nevnte kommisjonen kunne starte arbeidet med bevaringen av gravene. De sovjetiske representantene i kommisjonen var ambassaderåden ved den sovjetiske ambassaden i Oslo S.A. Mikailov og militærattaché ved ambassaden oberst G.G. Tarasov. ${ }^{361}$

\subsection{Gravkommisjonens mandat og diskusjon om antallet minnesmerker}

Fra norsk side ble det i desember 1951 påpekt at et forslag om en norsk-sovjetisk kommisjon til forhandling om gravflyttingssakene først ble fremsatt av russerne selv. Russerne hadde antydet et mandat til kommisjonen som var svært ulikt de norske formuleringene. Uttalelsene fra sovjetiske myndigheter tydet på at de ikke ønsket å diskutere videre flyttingen av gravene, men først og fremst ville forhandle om istandsetting og vedlikehold av gravene der de nå lå. Det at den norske regjeringen var enig i å oppnevne en blandet kommisjon for istand-

360 RA, Krigsgravtjenesten, eske 26-35. «Sovjetiske krigsgraver 1946-1952». Avskrift av telegram, fra Moskva 07.12.1951, til forsvarsdepartementet mottatt samme dag.

361 Nordlands Avis, 11.12. 1951. 
settelse av gravene og gravsamlingen til sovjetiske borgere, ble fra sovjetisk side tolket som at kommisjonens mandat som var angitt i sovjetisk noteveksling med norske myndigheter, var godkjent fra norsk side. Man mente derfor at den norske regjeringen måtte ta stilling til om de norske representantene straks skulle legge frem et forslag til et sterkt begrenset mandat for den blandede kommisjonen, eller om man først skulle få i gang forhandlinger om spørsmål man antok at det var lett å få til enighet om. Dette gjaldt spørsmål som planene for Tjøtta, og eventuelt reising av minnesmerker på en del tidligere gravfelter i Nord-Norge. Til slutt ble det påpekt at man skulle vente med striden om ytterligere flytting til dette spørsmålet meldte seg på dagsordenen. ${ }^{362}$

Ved kongelig resolusjon av 18. januar 1952 ble ekspedisjonssjef Johan G. Ræder fra Utenriksdepartementet og oberst Roscher Lund fra Forsvarsdepartementet oppnevnt som medlemmer av den norsk-sovjetiske kommisjonen til behandling av spørsmål vedrørende de sovjetiske krigsgravene i Norge. De norske medlemmene fikk beskjed om ikke å drøfte flyttingen av gravene i Nord-Norge eller gå med på noen inspeksjon av tidligere gravsteder i landsdelen. Korrespondansen mellom norske og sovjetiske myndigheter viser at man fra norsk side ønsket et svært begrenset mandat for kommisjonen. Mandatet skulle omfatte utforming av de endelige planene for anlegget og utsmykkingene av kirkegården på Tjøtta, drøftelser om gjennomføringen av den varslede samlingen av gravene til sovjetiske borgere i Sør-Norge og drøftelser om hvor det burde reises nye minnestøtter i Nord-Norge der det hadde vært større gravplasser. Fra sovjetisk side ble det antydet et mandat som avvek sterkt fra det som ble fremsatt fra norske myndigheter. Den sovjetiske regjeringen var opptatt av at kommisjonens oppgave måtte omfatte vedlikehold av gravene og stoppe planene som de betraktet som en utslettelse av sovjetiske soldaters graver. Uttalelsene fra sovjetisk side ga grunn til å tro at de ikke ville diskutere videre flytting av gravene, men heller forhandle om istandsetting og vedlikehold av gravene hvor de lå. ${ }^{363}$

Kort tid etter etableringen av kommisjonen var oberst Roscher Lund interessert i å skaffe en generalplan for samling av samtlige krigsgraver i Norge. Han mente det ville være av vesentlig betydning at de norske medlemmene i kommisjonen kunne hevde overfor de sovjetiske medlemmene at samlingen av de sovjetiske gravene var et ledd i en større plan. I tillegg mente obersten at man ville stå sterkere under forhandlingene med sovjetisk side om det ble kommet frem til en ordning med engelskmennene angående flytting av enkelte britiske krigsgraver i Norge. Ekspedisjonssjef Ræder påpekte gode argumenter for at en

362 RA, Krigsgravtjenesten, eske 26-35. Notat til statsråd Hauge. 12.12.1951.

363 RA, Krigsgravtjenesten, eske 26-35. Notat. «De sovjetiske krigsgraver i Norge». Utenriksdepartementet, Oslo 02.021952. 
hadde begynt med samlingen av de sovjetiske gravene først, nemlig at disse var størst i antall, og at de var i en slik forfatning at noe måtte gjøres. Ræder var opptatt av at planene for Tjøtta måtte diskuteres med sovjetisk side. Spørsmålet var om de ville bli med på å utarbeide planene for kirkegården eller ikke. Det sakkyndige utvalget for gravene i Utenriksdepartementet var enige i at noe måtte gjøres snarest. Tjøtta måtte settes i stand før flyttingen av de resterende sovjetiske krigsgravene i Nord-Norge kunne utføres. I notatet ble det vist til gravene i Meløy, Mo i Rana og Karasjok. Roscher Lund var nærmest av den oppfatningen at de gjenværende gravene i Nord-Norge kunne bli liggende der de lå for å unngå mer blest om saken. Han viste til at etterretningssjef Vilhelm Evang også var av samme mening. ${ }^{364}$

De norske medlemmene i den norsk-sovjetiske kommisjonen for ordningen av de sovjetiske gravene ønsket en egen instruks om å fastholde at det burde finne sted en samling av de sovjetiske gravene i Norge. De viste samtidig til at en slik samling av graver var gjennomført i Nord-Norge bortsett fra på et par steder. De norske medlemmene var opptatt av at samlingen av gravene i SørNorge måtte fremstilles på en slik måte at dette var et ledd i en generell plan overfor de sovjetiske representantene, en plan som omfattet samtlige fremmede krigsgraver i Norge. Fra norsk side ønsket de å informere de sovjetiske representantene i kommisjonen om at amerikanerne allerede hadde hentet hjem sine døde, og at franskmennene hadde samlet sine døde på krigskirkegården i Narvik. De norske medlemmene ønsket også fullmakt til å informere om at andre graver, som de polske, jugoslaviske, tyske og britiske, ville bli samlet på egne kirkegårder. Videre var de norske medlemmene i tvil om hvorvidt det var hensiktsmessig å samle de sovjetiske gravene i Sør-Norge på de to stedene i området Kongsberg-Meheia og på Dovre, slik det var oppgitt i den foreløpige planen. De ønsket derimot å foreslå at de sovjetiske gravene ble samlet i de større byene i Sør-Norge. Fra et sikkerhetsmessig synspunkt måtte en samling i de større byene være like tilfredsstillende som en samling på gravplasser beliggende midt oppe i landet, mente de norske medlemmene. ${ }^{365}$

Forsvarsdepartementet var opptatt av å forhindre at sovjetiske representanter fikk anledning til å inspisere de tidligere gravstedene i regi av den norsk-sovjetiske kommisjonens arbeid i Nord-Norge. Etterretningstjenestens sjef, Vilhelm Evang, protesterte et år etter at aksjonen var gjennomført mot avgjørelsen om å erstatte minnesmerker som var fjernet. Årsaken var at mange minnesmerker var plassert i sensitive militære områder. Ut fra en sikkerhetsmessig betraktning

364 RA, Krigsgravtjenesten, eske 26-35. Notat. Utenriksdepartementet. Oslo 28.02.1952.

365 RA, Krigsgravtjenesten, eske 26-35. Notat. «Den blandete norsk-sovjetiske kommisjon for ordning av sovjetborgeres graver og gravplasser i Norge». Utenriksdepartementet. Oslo 29.02.1952. 
var det prinsipielt ikke tilrådelig at det skulle reises eller repareres noe minnesmerke med unntakelse av minnesmerket på Tjøtta.

Forsvarsdepartementet hadde antydet muligheten for å redusere antallet minnesmerker til åtte større monumenter, men selv reisingen av disse monumentene ville gi påskudd til gjentatte reiser gjennom store deler av landsdelen og til dels besøk på steder av stor militær betydning, som Lyngen-avsnittet og Fauske. Ifølge Evang var det uheldig at den norsk-sovjetiske krigsfangekommisjonens norske medlemmer i 1947 hadde gått med på å anbefale det sovjetiske forslaget om å reise eller reparere gamle minnesmerker på tidligere sovjetiske graver i Nord-Norge. Forsvarsstaben mente at flyttingen av gravene ville ha liten hensikt hvis kommisjonenes forslag ble godtatt. Forslaget innebar at det ville bli reist og reparert til sammen 38 minnesmerker i Nord-Norge. Evang viste til at disse minnesmerkene ville gi representanter for den sovjetiske ambassaden i Oslo anledning til å foreta jevnlige reiser i de tre nordligste fylkene for å bekranse minnesmerker. Ifølge Evang forekom det noe eiendommelig at det skulle reises fem minnesmerker i Lyngen-avsnittet (Kitdalen-Abaja-LulleSkibotn-Hatteng), og at det skulle reises minnesmerke på Bardu kirkegård, hvor det lå én russer begravd. Kommisjonen hadde foreslått minnesmerker reist på til dels utpreget strategiske punkter, hvorav nevnes: Kitdalen, Hatteng, Abaja, Skibotn, Lulle - alle liggende innenfor eller i umiddelbar nærhet av Lyngen festning. I Fauske lå minnesmerket nær en militær forsyningsstasjon. I Bardu, Skjold og Øvergård var minnesmerkene i nærheten av brigadeområder. I Bodin (Bodø), Høybuktmoen og Sørvollen (Hattfjelldal) lå det flyplasser i nærheten av minnesmerkene. For Sørvollen ble det også nevnt at det der var forekomster av krystaller, som ble betraktet som strategiske råvarer. For Harstads vedkommende ble det vist til de militære brigadeetableringene i regi av kystartilleriet. Forsvarsstaben ville sterkt anbefale at departementet ikke godkjente reising og reparasjon av minnesmerkene i henhold til kommisjonens forslag. ${ }^{366}$

Av sikkerhetsmessige årsaker ønsket Forsvarsstaben at det ikke ble reist eller reparert noe minnesmerke med unntagelse av minnesmerket på Tjøtta. I tilfelle departementet av politiske grunner måtte imøtekomme det sovjetiske ønsket i en viss utstrekning, foreslo de at det ble reist et minnesmerke i Bodø alternativt Narvik og et i Tromsø alternativt Harstad. Det ville da bli et minnesmerke på et sentralt sted $\mathrm{i}$ hvert av de tre nordligste fylkene, i og med at det allerede eksisterte et minnesmerke i Kirkenes. Sett fra et sikkerhetsmessig synspunkt betød dette at sovjetiske representanter i en viss utstrekning måtte gis anledning til å foreta offisielle reiser til disse tre stedene, men samtidig ville det være mulig å

366 RA, Krigsgravtjenesten, eske 26-35. Notat, «Reising av minnesmerker på tidligere russergraver i Nord-Norge», Forsvarsstaben II, Oslo den 13.09.1952. 
kontrollere reisene og dels dirigere reisene til bestemte kommunikasjonsmidler, som eksempelvis rutefly. ${ }^{367}$ Forsvarsdepartementet unngikk senere å ødelegge minnesmerker hvor det var teknisk mulig uansett hvilken forfatning de var i.

Forsvarsstaben mente at forutsetningen for hele flyttingen i Nord-Norge falt bort hvis det nå skulle reises minnesmerker hvor det tidligere hadde vært sovjetiske graver. Forsvarets overkommando var enig i dette.

Ni steder hvor det altså var foreslått av kommisjonen å reise nye minnesmerker, lå ved strategisk viktige punkter. Forsvarets overkommando var redd for at de sovjetiske representantene ville trekke seg ut av kommisjonen om dette ikke ble godkjent. For å dempe gemyttene noe ble det derfor foreslått at man kunne hevde at minnesmerkene ville komme på militært område. Forsvarsstaben arbeidet på samme tid med spørsmålet om sovjetiske graver som befant seg på militære områder, men dette arbeidet tok tid fordi det blant annet krevde et effektivt vakthold dersom slike områder skulle etableres. En mulig løsning var at Forsvarsdepartementet kunne nekte å reise minnesmerkene fordi det var under overveielse å gjøre de aktuelle gravstedene til militære områder. Likevel ble man fortsatt stående ved at det måtte reises 24 minnesmerker i NordNorge, og det måtte derfor overveies hvordan en skulle unngå inspeksjonsreiser til disse stedene. Forsvarets overkommando fremhevet at den norsk-sovjetiske kommisjonen aldri hadde fătt noen bestemt instruks for de forhandlingene som skulle føres. Kommisjonen hadde kun forholdt seg til notevekslingen som fant sted mellom Norge og Sovjetunionen i løpet av 1951. Det hadde vært en forutsetning at de norske militære medlemmene av kommisjonen skulle holde kontakten med Forsvarsstaben, men denne kontakten ble betraktet som mangelfull av Forsvarets overkommando. ${ }^{368}$ Forsvarets overkommando var villig til å strekke seg langt for å forhindre at det ble reist nye minnesmerker over de sovjetiske ofrene i Nord-Norge.

I august 1952 hadde kommisjonen møte angående minnesmerkene som skulle settes opp på tidligere gravsteder. De sovjetiske medlemmene i kommisjonen var enige i forslaget som var fremsatt fra norsk side, med noen forbehold. De sovjetiske medlemmene ønsket at større minnesmerker på to meter ble satt opp på åtte tidligere gravsteder. Dette var Skafferhullet (Elvenes), Elvebakken (Alta), Kitdalen, Kroken (Sørfold), Hestbrinken, Helland (Sørfold), Kobbvatn (Sørfold) og Fauske. Alle minnesmerkene skulle påføres en eikegreinsdekorasjon, og arealet rundt skulle avgrenses i en utstrekning på fire $\mathrm{x}$ fem meter. Videre ønsket man at minnesmerkene på følgende steder skulle repareres: Drevja, Mo i Rana, Brennhei, Beisford, Trondenes, Bardufoss, Lenvik, Holm,

367 Ibid.

368 RA, Krigsgravtjenesten, eske 26-35. Intern melding. Til statssekretæren fra 4. kontor. 18.09.1952. 
Bø i Engeløy, Vold i Buksnes, Høybuktmoen, Lebesby og Sørvollen i Hattfjelldal. Nordmennene var klare på at det ikke kom på tale å sette opp et nytt minnesmerke på Drevja, siden dette var militært område. De norske medlemmene ville komme tilbake til spørsmålet om reparasjon av det gamle minnesmerket på Drevja etter å ha studert forslaget nærmere. De sovjetiske medlemmene la videre frem forslag til nye minnesmerker på en og en halv meter på 18 steder $\mathrm{i}$ Troms og Nordland. De ønsket også å reise et nytt minnesmerke på Setermoen. Dette var ikke mulig, ifølge nordmennene, siden gravplassen lå på militært område, og man mente det måtte være tilstrekkelig med et nytt minnesmerke på den tidligere gravplassen som lå på Bardu like ved Setermoen. Når det gjaldt krigskirkegården på Tjøtta, uttalte de sovjetiske medlemmene i kommisjonen at de i prinsippet var enige i det norske forslaget som var fremlagt, men med noen forbehold. De ønsket den sovjetiske hærens merke, stjerne med hammer og sigd, på toppen av bautaen samt dekorasjon på forsiden. Etternavn og initialer skulle påføres på feltet der de kjente ofrene skulle legges. Minneplater hvor de ukjente skulle gravlegges, skulle påføres «ukjent» istedenfor nummer. Forhøyninger foran bautaen burde fjernes, muren dekkes med torv på toppen og arealet beplantes. Fra norsk side ble det uttalt at det ikke kunne komme på tale. Det ble hevdet at både billedhuggeren og arkitekten mente dette ville fullstendig forandre proporsjonene til bautaen. Videre uttalte nordmennene at de ville komme tilbake til spørsmålet om dekorasjon på et senere tidspunkt. De norske medlemmene ga til slutt uttrykk for at de var lei av stadige spørsmål fra sovjetisk side om når anlegget på Tjøtta ville stå ferdig. ${ }^{369}$

Den norsk-sovjetiske kommisjonen gjennomførte en rekke inspeksjoner av de sovjetiske gravene i Sør-Norge i løpet av 1952. I desember var kommisjonen i Østfold for å inspisere tre gravsteder. Ved Mysen kirkegård var det reist en vanlig gravstein på graven til en sovjetisk soldat. Kommisjonen rapporterte at vedlikeholdet var utmerket og ble besørget av kommunen. Angående gravstedet $\mathrm{i} ø$ østre Fredrikstad ble det påpekt at dette var en vanlig kirkegård og ikke en krigskirkegård. Her var det gravlagt to navngitte sovjetiske borgere. Gravene lå like ved engelske og tyske graver fra første verdenskrig. Navnene på ofrene var inngravert på norsk og russisk på en granittstein. Steinen var reist av den kommunistiske ungdomsforeningen i Fredrikstad, og vedlikeholdet var utmerket, ifølge kommisjonen. På Rygge kirkegård var det reist en stein og et smijernskors på en enkeltgrav. Sognepresten på stedet fortalte at dette var reist av politiske flyktninger i Norge. ${ }^{370}$

369 RA, Krigsgravtjenesten, eske 26-35. Notat. Utenriksdepartementet. Oslo 26.08.1952.

370 RA, Krigsgravtjenesten, eske 26-35. Rapport om krigsgravinspeksjon. «Den blandete norsk-sovjetiske kommisjon for ordning av sovjetborgeres graver og gravplasser i Norge». Utenriksdepartementet. Oslo 08.12.1952. 


\subsection{Vedlikehold av graver}

Med tanke på hvor mye ressurser og utgifter den sovjetiske ambassaden brukte for å ordne de sovjetiske krigsgravene, er det lite som tyder på at de kritiserte norske myndigheter for at tidligere ordninger av gravstedene var bortkastede penger. Likevel var det ikke helt problemfritt at sovjetiske myndigheter var så tett tilknyttet arbeidet med vedlikeholdet av gravene som ble flyttet. I juli 1951 advarte etterretningssjef Vilhelm Evang om at en måtte være forberedt på kritikk fra ulike hold i forbindelse med den planlagte samlingen av gravene i Sør-Norge. Han viste til at det på en del kirkegårder var sovjetiske graver som ble vedlikeholdt og bekostet av et sovjetisk samband, og at denne organisasjonen sikkert ville nære en slags eierskapsfølelse til gravstedene. Evang var forberedt på at det også kunne bli reist kritikk over at gravene som skulle flyttes, hadde vært flyttet tidligere, og han mente at man også måtte regne med kritikk fra lokale kommunistorganisasjoner. ${ }^{371}$

Det er åpenbart at vedlikeholdet ikke ble godt nok ivaretatt noen steder. Et eksempel var de sovjetiske og jugoslaviske krigsgravene i Øysand i Sør-Trøndelag. En av de norske representantene i gravkommisjonen, oberst Roscher Lund, viste kommisjonen rundt i Trøndelag og uttalte at forholdene ved Øysand var det verste han noensinne hadde sett. Obersten mente det var vanskelig å unngå å bruke sterke uttrykk for å skildre forholdene ved de vel 160 jugoslaviske og sovjetiske gravene på dette stedet. Han sa at det måtte karakteriseres som en skandale at gravene hadde fătt ligge slik i forfall i årevis. Gravene lå skjult for den alminnelige trafikken på riksveien på Øysand og var plassert i olderskogen like nedenfor brua, og bare de som kjente til stedet, fant frem til gravplassen. Et stort minnesmerke vitnet om udåden som ble begått her. Ifølge obersten vitnet en brun, tørr krans med rød sløyfe om at det hadde vært folk her en eller annen 1. mai. Han var ikke sikker på hva som var verst av om folk husket gravene bare hver 1. mai, eller om de glemte gravene for godt. Om tilstanden på stedet uttalte obersten:

Nei, noen minnelund er gravplassen på Øysand ikke. Her ligger nedbrutte oldertrær over gravene, alt slags mulig rask er strødd utover plassen, og endelig har elva hjulpet til med å samle slam og rask på gravplassene. Det er bare så vidt man i dag kan skimte navnene på skiltene hist og her. ${ }^{372}$

371 RA, Krigsgravtjenesten, eske 26-35. «Plan utarbeidet etter oppdrag fra sjefen for Forsvarsdepartementet på grunnlag av beslutning fattet i Regjeringen den 26. juni 1951». Udatert.

372 Nidaros, 29.10.1952. 
Ordføreren i Leinstrand fortalte at kommunen aldri hadde hatt noe ansvar for gravstellet av gravplassen ved Øysand. De hadde alltid ment at dette var statens ansvar. Han mente dessuten at det var vanskelig å sette gravplassen ved Øysand i skikkelig stand. Gravene lå på en flate ned mot elva og hver vår gikk elva over gravene. Dette resulterte som regel $\mathrm{i}$ at gravplassen lå en meter under vann. Ordføreren mente at det var på høy tid at det ble gjort noe for å rette på disse forholdene, og håpet på at besøket av den sovjetiske gravkommisjonen ville resultere i utbedringer av gravplassen. De jugoslaviske gravene ble senere flyttet til Moholt kirkegård i Trondheim og de sovjetiske ble flyttet til Vinjeøra.

Lederen for distriktskontoret for krigsgraver i Trøndelag, feltprest Gunnar Wold, mente også at forholdene ved gravplassen på Øysand var under all kritikk. Han stilte spørsmålet om det var best å flytte krigsgraver i Trøndelag på samme måte som det var blitt gjort i Nord-Norge. Det eksisterte ifølge feltpresten 30 krigsgravplasser i Trøndelag, og en sentralisering var en fordel, mente han. Men personlig var feltpresten av den oppfatningen at man burde være ytterst forsiktige med en flytting av gravene. Han mente det var stor forskjell på vedlikeholdet. Der hvor gravene var lett tilgjengelige, var vedlikeholdet godt. Dette gjaldt blant annet i Oppdal, Charlottenlund, Orkanger og i Grong. Det var helst gravene i utmarkene som manglet vedlikehold. ${ }^{373}$

I juni 1951 hadde den sovjetiske ambassaden lagt frem sin plan for vedlikehold av gravene, og på dette tidspunktet antok de at bare i unntakstilfeller ville de sovjetiske soldatenes lik bli flyttet. Den sovjetiske regjeringen mente at det var fullstendig uholdbart at den norske regjeringen forsøkte å fremstille gravsaken på en slik måte at de først i august 1951 hadde blitt informert om innvendingene fra sovjetisk side mot planene om flyttingen av gravene. De viste i den anledning til den sovjetiske ambassadens note fra 31. mai $1951 \mathrm{og}$ erklæringen fra den sovjetiske ambassadøren til den norske utenriksministeren 21. juni 1949. I begge disse dokumentene fremgikk det klart at den sovjetiske ambassaden hadde reist innvendinger mot masseflyttingen av gravene.

Den norske regjeringen hadde ikke godkjent planen fra ambassaden, og i stedet for å ta seg av gravene ble de fjernet i hele Nord-Norge, hevdet den sovjetiske regjeringen. Fra sovjetisk side mente man at den norske regjeringen forsøkte å benekte fakta angående norske myndigheters forhånelse av sovjetiske ofre. De mente at forhånelsen var godt kjent også blant den norske befolkningen. I verbalnoten ble det vist til at befolkningen i en rekke norske byer, som Narvik, Tromsø, Mo i Rana og andre, var opprørt over en slik forhånelse fra norske myndigheters side. ${ }^{374}$

373 Ibid.

374 RA, Krigsgravtjenesten, eske 26-35. «Sovjetiske krigsgraver i Norge». Udatert. 


\subsection{Gravkommisjonens reise til Nord-Norge}

Den sovjetiske gravkommisjonen reiste på inspeksjon til ulike gravsteder i Norge året etter at «Operasjon asfalt» var avsluttet. Forsvaret ønsket at gravkommisjonen skulle ledsages av en sikkerhetsoffiser på reisen nord for Mosjøen. Dette ble avslått av øverstkommanderende for Forsvaret i NordNorge general Dahl, fordi de ikke hadde rukket å ansette en sikkerhetsoffiser på dette tidspunktet. Foreløpig hadde de bare fått ansatt halvparten av antallet offiserer innen etterretning og sikkerhet, ifølge stabssjefen til ØKN (Øverstkommanderende i Nord-Norge). ${ }^{375}$ Sikkerhetsspørsmål knyttet til sovjetiske representanters besøk var sentrale etter at operasjonen var gjennomført i Nord-Norge, og Forsvaret i Nord-Norge hadde ikke tilstrekkelige ressurser til etterretning og sikkerhet.

Militærattaché oberst Tarasov var åpenbart ikke fornøyd med valget av Tjøtta. Under kommisjonens reise til Nord-Norge i 1952 spurte obersten om årsaken til flyttingen av alle gravene og hvorfor Tjøtta ble valgt. «Hvem har funnet på flyttingen?» ville obersten vite. Feltprest Guttormsen, som var med på hele reisen, svarte at flyttingen var bestemt av norske myndigheter, og at stedet var valgt fordi det var et sentralt og pent sted. ${ }^{376}$ Under kommisjonens besøk på Drevjamoen i Mosjøen var oberst Tarasov interessert i å få vite hvem som hadde jobbet med oppgravingen av gravene. Han fikk vite av lensmannen at det var en norsk kaptein og arbeidere fra Nordland og Troms som hadde gjennomført oppgravingen. Obersten hadde ikke hørt om noen kaptein og mente det var nødvendig å få tak i ham. Feltpresten fortalte da at denne kapteinen hadde vært omtalt $\mathrm{i}$ alle landets aviser under arbeidet med oppgravingen. Obersten spurte om noen av graverne var fra Drevja, men feltpresten svarte at han ikke visste noe om det. Lensmannen kunne fortelle at lokale myndigheter ikke hadde vært til stede under oppgravingen siden dette var militært område. Tarasov antok da at noen lik kunne ha blitt liggende igjen. Feltpresten oppfattet dette som en insinuasjon, og at dette i så tilfelle ville vært en grov pliktforsømmelse av vedkommende offiser. Tarasov sa da at nordmennene hadde misforstått. Han mente at det kunne være lik som var blitt liggende igjen andre steder også. Neste dag møtte kommisjonen regimentssjef oberstløytnant Skaar og leirkommandant major Pedersen ved Drevjamoen. Oberst Tarasov ville vite om det var andre steder krigsfanger var gravlagt i området. Major Pedersen svarte nei. Oberstløytnant Skaar for-

375 RA, Krigsgravtjenesten, eske 26-35. «Reise til Nord-Norge for den norsk-sovjetiske gravkommisjon». Harstad den 5. juli 1952.

376 RA, Krigsgravtjenesten, eske 26-35. Notat. «Rapport om Norsk-Sovjetisk kommisjons reise til Nord-Norge». 24.07.1952. 
klarte at det hadde vært en sykeleir under norsk administrasjon med norske leger etter frigjøringen i samme område. Tarasov ønsket å hilse på legen, men feltpresten fortalte da at doktor Oftedahl var død. Oberstløytnant Skaar kunne også fortelle at han selv hadde trampet rundt overalt og at det ikke var muligheter for noen andre gravsteder. Tarasov var fornøyd og erklærte at når to autoriteter uttalte seg så sterkt, kunne man være sikker. ${ }^{377}$

Under kommisjonens besøk på Hestbrinken krigskirkegård i Saltdal var det uenighet om antallet sovjetiske gravlagte. Norske myndigheter hadde oppgitt 682 gravlagte, men sovjetiske myndigheter mente at antallet var nærmere 1000. Etter en samtale med graveren ble det oppklart at 682 sovjetiske og elleve jugoslaviske ofre var gravd opp. Tarasov mente at alt tallmaterialet måtte være feil. Han ville høre opplysninger om antallet fra lokale myndigheter. Feltpresten mente at de norske sivile ikke hadde hatt adgang til fangeleirene, og at de derfor ikke kunne vite det nøyaktige antallet graver. Tarasov ga seg ikke og ville diskutere antallet gravlagte med folk som bodde i nærheten. Kommisjonen dro derfor til nærmeste nabo, Viktor Storjord. Han fortalte at han hadde bodd der hele tiden, og at han hadde passet på kirkegården. Storjord hadde hørt at antallet gravlagte var 693, og at det ikke hadde blitt gravlagt sovjetiske krigsfanger andre steder. Deretter fikk kommisjonen opplyst at likene på Hestbrinken var gravlagt i 1945 av daværende sogneprest Vågdal etter at de var samlet fra andre steder i området. Vågdal husket ikke antallet graver, men den nåværende sognepresten oppga det samme antallet som graveren hadde gitt.

Kommisjonen fikk også problemer med å fastsette antallet gravlagte ved krigskirkegården i Beisfjord. Lokalbefolkningen visste ikke noe om antall døde og trodde ikke russerne selv visste det heller. Tarasov spurte om hvem som hadde ført regnskap over de begravde under krigen. Feltprest Guttormsen svarte at det ble ført "regnskap» ved oppgravingen, og var det blitt ført samme type «regnskap» under gravleggingen, hadde det vært unødvendig å reise til Beisfjord. Etter å ha spurt flere fra lokalbefolkningen om opplysninger, erklærte Tarasov at han ikke trodde lokale myndigheter kunne hjelpe dem mer. Feltpresten ga til slutt en oversikt over antallet døde i Beisfjord. Han hadde antatt at det var gravlagt ca. 500 serbere i Beisfjord, og at antallet sovjetiske døde var 193. Ved oppgravingen viste det seg å være 305 sovjetiske døde fordi det lå flere ofre i hver grav. Ved besøket på Trondenes kirkegård i Harstad ble Guttormsen og Tarasov svært uenige i spørsmålet om hvorvidt en kunne stole på lokalbefolkningens fortellinger om brenning av sovjetiske lik under krigen. Guttormsen var villig til å si at det var sannsynlig og meget

377 Ibid. 
mulig at det var brent lik, men han beklaget at undersøkelsene på Trondenes var forgjeves med tanke på at de ikke hadde kommet frem til et endelig resultat over antallet sovjetiske gravlagte. Denne bemerkningen resulterte i en to timer lang diskusjon hvor Tarasov påstod at Guttormsen hadde sagt at reisen til Beisfjord var nytteløs. Han hevdet at Guttormsen hadde fătt instruksjoner om å overbevise russerne om reisens nytteløshet. Tarasov ønsket derfor å reise hjem.

Etter å ha fått instruksjoner fra Utenriksdepartementet forsikret Guttormsen om at han ikke anså reisen for å være nytteløs. Neste morgen erklærte Tarasov at han likevel ville fortsette reisen. Etter besøket på Engeløy i Steigen regnet Tarasov dette for det siste stedet på kommisjonens reise i Nord-Norge. Han takket Guttormsen for at han hadde gjort dette arbeidet mulig, og sa at det ville være til hjelp i arbeidet med å komme til en løsning på alle spørsmål angående monumenter og graver. Guttormsen ga uttrykk for takknemlighet og mente at det ikke var umulig å komme frem til en løsning som begge parter kunne godta. ${ }^{378}$

Etter kommisjonens reise til Nord-Norge fremhevet de sovjetiske representantene at reisen hadde vært nyttig. Etter deres mening hadde reisen bidratt til klarlegging av en rekke spørsmål i tilknytning til ordningen av de tidligere gravstedene til sovjetiske borgere og oppsettingen av minnesmerket og anlegget på gravplassen på Tjøtta. De sovjetiske representantene i kommisjonen ønsket at det ble satt opp større minnesmerker på noen av de stedene hvor det hadde vært gravlagt et større antall sovjetiske borgere. Fra norsk side ble det svart at en hadde tenkt seg at alle minnesmerkene hadde en standardstørrelse fordi arbeidet da kunne utføres raskere. Fra sovjetisk side ble det uttalt at om partene kom til enighet om hvordan minnesmerkene skulle se ut, kunne man allerede nå instruere de lokale myndighetene om å forberede de aktuelle områdene for oppsetting av minnesmerkene. Nordmennene sa seg enige i dette. Partene kom også til enighet om at transkripsjon fra russiske til latinske bokstaver skulle gjøres av norske myndigheter, og deretter skulle det bli gjennomgått av sovjetiske myndigheter. ${ }^{379}$

378 RA, Krigsgravtjenesten, eske 26-35. Notat. «Rapport om Norsk-Sovjetisk kommisjons reise til Nord-Norge». 24.07.1952.

379 RA, Krigsgravtjenesten, eske 26-35. Protokoll. «18. møte i den blandete norsk-sovjetiske kommisjon for ordning av sovjetborgeres graver og gravplasser i Norge». 18.08.1952. 


\subsection{Gravkommisjonen og ny flytting av graver i Sør-Norge}

Planene for en ny samling av gravene i Sør-Norge ble presentert i desember 1951 i et notat til statsråd Jens Christian Hauge fra statssekretær Andreas M. Andersen i Forsvarsdepartementet. Her ble det oppgitt at planen gikk ut på en samling av gravene til to sentrale gravfelt: Ett i området KongsbergMeheia og ett på Dovre. I notatet ble det sagt at en tok det for gitt at sovjetisk side ikke ville akseptere en så sterk samling av gravene. Eksempler som ble nevnt var felles gravfelt for ett eller et par fylker. I notatet ble det imidlertid påpekt at de sovjetiske gravfeltene også i Sør-Norge lå på eller i nærheten av militært område i en rekke tilfeller. En viss flytting var derfor tilrådelig. Statssekretæren la ved en liste over sovjetiske graver på militært område i SørNorge. På listen var følgende steder oppført: Vigra, Setnesmoen, Haslemoen, Jørstadmoen, Voss (Bømoen), Oddernes, Gardermoen, Trandum, Bolærne og Stavern. ${ }^{380}$ Sovjetiske falne ble også samlet på egne sovjetiske krigskirkegårder på Verdalsøra, Vinjeøra, Sunndalsøra og Oppdal. Andre ble gravlagt på ordinære kirkegårder - i større felt, fellesgraver eller i enkeltgraver. ${ }^{381}$

Under et møte i Utenriksdepartementet i februar 1952 ble spørsmålene omkring samling av de sovjetiske gravene i Sør-Norge drøftet. Alternativene var en samling av gravene på to steder i henhold til foreliggende planer, eller en mindre sterk konsentrasjon. De sakkyndige fra Utenriksdepartementet mente at en samling måtte tilstrebes, fordi det erfaringsmessig oppstod «kommunistisk sellevirksomhet» i områdene ved de forskjellige gravstedene. Oberst Roscher Lund mente at gravene burde samles i så stor grad som overhodet mulig. Gravene måtte for det første flyttes i de tilfellene hvor de lå på militært område. Dessuten burde en flytte gravsteder hvor det lå få ofre. Han viste til ordningen som sovjetiske myndigheter hadde godtatt i Finland, der gravsteder hvor det var mindre enn 30 gravlagte, ble samlet. Dette var en god ordning tatt i betraktning at det på de aller fleste gravsteder i Sør-Norge var gravlagt færre ofre enn dette, mente Roscher Lund. ${ }^{382}$

Fra Utenriksdepartementets side ble det satt spørsmålstegn ved å flytte gravene som var på ordinære kirkegårder. En burde være oppmerksom på at folk reagerte sterkest på flyttinger fra slike steder. Feltprest Guttormsen nevnte i denne forbindelse at Norsk-Sovjetrussisk Samband og kommunale myndigheter på flere steder hadde reist minnesmerker på russergravene. Ekspedisjonssjef i Utenriksdepartementet, Johan G. Ræder, mente imidlertid at det ikke

380 RA, Krigsgravtjenesten, eske 26-35. «Notat til statsråd Hauge». 12.12.1951.

381 Notat, Krigsgravtjenesten ved Eiliv Thorheim, udatert, Oslo mars 2002.

382 RA, Krigsgravtjenesten, eske 26-35. Notat. Utenriksdepartementet. Oslo 06.02.1952. 
var noe betenkelig i å flytte disse gravene hvis en først ble enig med de sovjetiske representantene om at flytting kunne skje. Ifølge norske lovbestemmelser skal lik begraves på regulære kirkegårder. Grunnen til denne bestemmelsen er i første omgang knyttet til hensynet til registrering og legitimering. Feltprest Guttormsen påpekte i denne sammenhengen at krigskirkegårder ikke var kirkegårder i vanlig forstand. Egentlige krigskirkegårder fantes det bare et par stykker av i landet. Gravstedene fikk gjerne denne betegnelsen når et større antall personer lå gravlagt der. Under dette møtet ble spørsmålet om reising av minnesmerker ikke diskutert nærmere, men man mente at det var uheldig at det i en note (et dokument) til Sovjetunionens ambassade var gitt uttrykk for at en på norsk side mente at nye minnesmerker burde reises der hvor de gamle var fjernet, og der hvor det hadde vært større gravsteder. ${ }^{383}$

I et internt møte i Utenriksdepartementet i januar 1953 diskuterte de norske medlemmene i den norsk-sovjetiske kommisjonen hvilke sovjetiske graver i Sør-Norge som burde flyttes, og hvilke som burde bli liggende. I et notat fra møtet ble det oppgitt at gravstedene på Haslemoen, Jørstadmoen, Voss og Ørlandet kunne bli avsperret. Hensynet som ble lagt til grunn for hvorvidt en grav burde flyttes eller ikke, var de enkelte gravenes tilstand og muligheten for vedlikehold. I enkelte tilfeller var det militære hensyn som ble avgjørende for om gravene burde flyttes eller ikke. ${ }^{384}$ Litt senere ble samlingen av sovjetiske krigsgraver i Sør-Norge tatt opp på et nytt møte mellom kommisjonens norske medlemmer og Utenriksdepartementet. Her ble det enighet om å legge frem en fortegnelse for Forsvarsstaben over de sovjetiske krigsgravstedene som lå i eller i umiddelbar nærhet til militære områder, og som av sikkerhetsmessige grunner burde flyttes. Gravsteder som lå på militært område, var Tromøy, Jørstadmoen, Haslemoen, Gardermoen, Trandum, Vardås, Bolærne og Stavern. Gravstedene som lå ved militært område, var Ørlandet, Voss, Elverum, Horten og Rygge. ${ }^{385}$ De sovjetiske ofrene på gravfeltene ved Gardermoen og Trandum ble gravd opp og kremert i 1953. Urnene ble sendt til Oslo, hvor de ble satt ned på Vestre gravlund. Gravfeltet på Gardermoen lå ikke innenfor området som var inngjerdet som militærplass. Det sovjetiske gravfeltet på Trandum lå i nærheten av nordre port til Gardermoen militærplass. Feltet lå like ved veien og var godt markert. ${ }^{386}$ Begge gravfeltene ble sannsynligvis flyttet på grunn av nærheten til det militære anlegget på Gardermoen.

383 Ibid.

384 RA, Krigsgravtjenesten, eske 26-35. Notat. Utenriksdepartementet. Oslo 07.02.1953.

385 RA, Krigsgravtjenesten, eske 26-35. «Sammendragninger av russiske krigsgraver i det sydlige Norge». Oslo 24.02.1953.

386 RA, Krigsgravtjenesten, eske 26-35. «Konsentrering av russiske krigsgraver i SørNorge». Udatert Oslo desember 1953. 
Det skulle vise seg at Forsvaret ønsket å flytte et langt større antall gravsteder enn dette i Sør-Norge. Sikkerhetsoffiserer fra Forsvarsstaben og forsvarsgreinene ønsket å flytte 55 av de 114 sovjetiske gravstedene i Sør-Norge. Dette omfattet blant annet alle gravene i Østfold og Vestfold, og gravsteder i byene Fredrikstad, Larvik, Sandefjord, Kristiansand S., Stavanger og Bergen. Ifølge kommisjonens norske medlemmer var flyttingen av krigsgraver i Norge en sak som helt klart kunne avgjøres av norske myndigheter. Ingen internasjonale forpliktelser var til hinder for å gjennomføre en samling, og dette var blitt fremholdt klart overfor russerne. I tillegg ble det påpekt at regjeringen $ø n s k e t$ å få denne saken ut av verden uten ytterligere politiske komplikasjoner og uten en ubehagelig pressekampanje som russerne lett kunne sette i gang i Norge om man ikke ble enige. Kommisjonen viste til at 85 prosent av de sovjetiske gravene lå på ordinære kirkegårder. På 42 av gravstedene hadde bygdefolk og organisasjoner satt opp minnesmerker. Det ble spesielt påpekt at minnesmerkene var pene, og som oftest satt opp av ikke-kommunistiske organisasjoner. Man var også opptatt av at den sivile opinionen var imot å forstyrre gravfreden hvor dette ikke var åpenbart nødvendig. Forsvaret fryktet at denne opinionen ville komme kommunistene til hjelp om det igjen ble satt i gang propaganda mot flyttingen.

Flytting av graver som allerede hadde vært flyttet en eller flere ganger, ville bli problematisk. Ved en del gravsteder som var foreslått flyttet, som Jørstadmoen og Lista, hadde begravelsen funnet sted med offisiell norsk og sovjetisk deltakelse. Det ville i disse tilfellene bli vanskelig å begrunne en flytting. Under tidligere forhandlinger med sovjetiske myndigheter hadde de godtatt at gravene på Jørstadmoen lå på forbudt militært område, og at det derfor ikke ville bli anledning til å besøke gravene. Dette ble foretrukket fremfor flytting av gravene. Hærens representant mente at for å kamuflere de viktigste militære stedene hadde man strukket grensene for de områdene som en ønsket frigjort for sovjetiske graver, utover det som strengt tatt hadde vært nødvendig av viktige militære grunner. De norske medlemmene i kommisjonen fremhevet i denne sammenhengen at de fryktet at sovjetiske myndigheter ville ha nok opplysninger til å gjennomskue en slik forholdsregel med de relativt enkle arbeidsforholdene de hadde i Norge. For øvrig mente kommisjonens norske medlemmer at det nyttet lite å flytte graver fra større byer eller fra turistsentre, hvor det likevel var lett for sovjetisk side å finne unnskyldninger for besøk som de måtte ønske å foreta. Fra norsk side i kommisjonen var oppfatningen på dette tidspunktet at de sovjetiske gravene som måtte flyttes av reelle militære grunner, skulle flyttes etter norske bestemmelser uten diskusjon med sovjetisk side. Hvor dette av politiske grunner var vanskelig, som for eksempel på Jørstadmoen, skulle russerne meddeles 
at gravene kunne ligge om de ønsket dette, men området ville bli avsperret av militære grunner. Graver som var satt i god og permanent orden av lokale myndigheter eller institusjoner, ville ikke norske myndigheter foreslå flyttet. Der gravene ikke var satt i stand og vedlikeholdt, ville kommisjonens norske medlemmer foreslå at de ble samlet, men de var klar over at dette kunne bli vanskelig å få gjennomført. ${ }^{387}$

For at den norsk-sovjetiske kommisjonen skulle kunne komme videre med sitt arbeid, var det fra norsk side ønskelig å redusere antallet sovjetiske graver som måtte flyttes av militære grunner. De norske medlemmene i kommisjonen ønsket å dele de militære kravene i følgende to kategorier:

a) De graver som det er uomgjengelig nødvendig å få flyttet, fordi de ligger i eller like opptil viktige militære anlegg.

b) De som det er ønskelig å få flyttet, fordi de ligger i militært viktige områder, men hvor en eventuelt kan diskutere saken med russerne. ${ }^{388}$

Fra norsk side var det et ønske at saken ble behandlet så raskt som mulig slik at kommisjonen kunne fortsette arbeidet.

Under den norsk-sovjetiske kommisjonens arbeid med samling av gravene i Sør-Norge i 1953 viste det seg etter hvert at de to lands syn på hvordan gravene burde ordnes, ikke kunne forenes. Av 114 gravsteder var det foreslått av de norske representantene at 40 av disse skulle flyttes av hensyn til gravenes tilstand, og for at det skulle bli mulig å føre et tilstrekkelig tilsyn med dem. De sovjetiske medlemmene i kommisjonen var ikke enig i denne avgjørelsen. 20 av gravplassene ble forlangt flyttet av norske militære myndigheter. For en del av de gravplassene som de militære myndighetene krevde flyttet, kunne det bli vanskelig å sannsynliggjøre at reelle militære hensyn gjorde seg gjeldende. Dette gjaldt spesielt krigskirkegården Charlottenlund (Strinda) i Trondheim med 30 graver og enkeltgravene på de ordinære kirkegårdene i Mysen og Rygge. Nordmennene mente at eneste utvei i tilfelle flytting var å si at dette var et militært krav. Kirkegården på Lista var nettopp blitt satt i stand og en rekke lik var flyttet dit. Hverken på Lista eller Charlottenlund var det nå gunstig å skulle flytte gravene, ifølge de norske medlemmene. De sovjetiske medlemmene insisterte på sin side at graver ikke måtte flyttes, men settes i stand på de stedene de lå. Å foreta flytting betød å ødelegge gravsteder var deres syn. De sovjetiske forhandlerne hadde foreslått flytting av bare ni av gravplassene. Dette var plasser der de måtte innrømme at nåværende belig-

387 RA, Krigsgravtjenesten, eske 26-35. «Ad russiske krigsgraver». Oslo 27.03.1953.

388 Ibid. 
genhet av praktiske hensyn ikke kunne brukes. Men selv i disse tilfellene så de for seg flytting til nærmeste brukbare sted og ikke til større samleplasser. Av de ni nevnte stedene, var det fem av disse gravplassene som måtte flyttes av militære grunner. Fra sovjetisk side mente man at dette var et rimeligere kompromiss enn det forslaget som den norske parten hadde lagt frem, idet russerne betraktet alle gravene i Norge under ett. Årsaken til dette synet fra sovjetisk side var at alle gravene i Nord-Norge ble flyttet til Tjøtta - det var bare gravene i Mo i Rana som ikke ble flyttet. ${ }^{389}$

Selv om flytting av graver på militære områder skulle skje uten diskusjon, mente norske forhandlere at russerne måtte bli informert om at det ville bli foretatt flytting av de 20 gravplassene som militære myndigheter hadde forlangt flyttet. I tillegg til de ni nevnte stedene var det fire gravplasser som de sovjetiske medlemmene selv hadde foreslått flyttet, da disse var i en slik forfatning at noe måtte gjøres snarest. Alle disse gravplassene måtte før eller senere flyttes, men man var forberedt på at dette ville medføre protester fra sovjetisk side. For de øvrige 16 gravplassene der norske forhandlere hadde foreslått flytting, men sovjetisk side hadde motsatt seg dette, ble det nå lagt frem flere alternativer. Første alternativ var at alle disse gravene ble liggende. Neste alternativ var å sette i gang flytting av gravene uten noen enighet med sovjetisk side. Et tredje alternativ var å gå med på at gravene ble satt i stand med monumenter etter det sovjetiske forslaget på de stedene der gravene lå, hvis den sovjetiske parten godtok flytting av de tidligere nevnte 24 gravplassene. Ulempene med dette alternativet var at de norske forhandlerne ville oppgi sine prinsipper og dermed underkjenne ordningene som var gjennomført i Nord-Norge. Dessuten ville dette alternativet medføre betydelige omkostninger til istandsettelse og vedlikehold. Det siste alternativet var at nordmennene forhandlet seg frem til enighet om hver enkelt av disse gravene ved å bytte en grav mot en annen med de sovjetiske forhandlerne. Det ble fremhevet at denne fremgangsmåten var lite tiltalende, men forhåpentligvis ville føre til at det ble oppnådd enighet om ytterligere en del flyttinger. ${ }^{390}$ Det å bytte en grav mot en annen førte åpenbart ikke til resultater, og under forhandlingene i den norsk-sovjetiske kommisjonen viste det seg at det ikke var mulig å forene det norske og det sovjetiske synet på hvordan gravene burde ordnes. De norske forhandlerne hadde gått inn for en samling av gravene i enkelte større byer, og det sovjetiske standpunktet var at gravene i størst mulig utstrekning burde bli liggende på nåværende

389 RA, Krigsgravtjenesten, eske 26-35. Notat. «Den blandete norsk-sovjetiske kommisjon til behandling av spørsmål vedrørende sovjetgravene i Norge». Oslo 06.05.1953.

390 Ibid. 
steder. For å kunne komme videre med saken ble det bestemt at man skulle innhente ny instruks fra regjeringen på grunnlag av en fullstendig utredning av de mulighetene som forelå. ${ }^{391}$

I protokollen for det 39. møtet til den norsk-sovjetiske kommisjonen, som ble avholdt 25 . juni 1953 , ble det opplyst at den norske parten ville utarbeide detaljerte planer for ordningen av enkelte større sovjetiske gravplasser i Sør-Norge. Deretter ville planene bli drøftet med Sovjetunionens ambassade i Oslo. I planen ble ordningen av gravene på følgende steder beskrevet: Oppdal, Lademoen, Sunndal, Haug i Norderhov, Kristiansand, Spangereid, Lyngdal, Egersund, Egenes i Stavanger, Vinjeøra, Aukra, Laksevåg og Jørstadmoen. Da planen ble presentert for ambassaden i juli 1954, spurte representanten for ambassaden, Katajev, om hvordan det lå an med de gravplassene som ikke var nevnt i planen. Han fikk til svar at større forandringer på andre sovjetiske gravsteder ville man komme tilbake til senere. Ellers dreide det seg om vanlig vedlikehold på disse stedene. Katajev ga uttrykk for stor takknemlighet for det arbeidet som var blitt utført. Ekspedisjonssjef Boye i Utenriksdepartementet foreslo følgende inskripsjon på minnesmerkene: «Til minne om sovjetiske soldater som mistet livet i Norge under krigen 1941-1945 og som er gravlagt her.» Nedenfor inskripsjonen skulle navnene på de identifiserte og antallet av ikke-identifiserte føres opp. I enkelte tilfeller var lik fra flere gravsteder flyttet sammen, og hvis de sovjetiske representantene ønsket det, kunne det oppgis hvor disse var flyttet fra. Katajev var enig i forslaget til inskripsjon og ønsket også at den eventuelt oppga hvorfra de gravlagte var flyttet. Boye opplyste at så snart type monument var avklart, og teksten til inskripsjonen var klar, ville man gå i gang med å lage minnesmerker for Lista, Kristiansand, Ålesund, Sande, Masfjorden, Fana og Grong. ${ }^{392}$

De sovjetiske medlemmene i den blandede kommisjonen motsatte seg planene om flyttingen av krigsgraver på tre steder i 1953. Utenriksdepartementet og de norske medlemmene i kommisjonen møttes derfor for å diskutere vanskelighetene med flytting av gravene ved Charlottenlund på Strinda i Trondheim, Soma på Jæren og Tromøya ved Arendal. Det ble opplyst på møtet at flyttingen av 17 av 20 gravplasser var i orden, men russerne hadde protestert mot flytting av graver på de tre nevnte stedene. På Soma regnet en med vanskeligheter med opinionen blant sivilbefolkningen. Fra Forsvarets side ble det foreslått at gravene skulle bli liggende, men at området skulle forbys for utlendinger. For Charlottenlunds vedkommende ble det fra Luftfor-

391 RA, Krigsgravtjenesten, eske 26-35. Notat, Utenriksdepartementet. 13.05.1953.

392 RA, Krigsgravtjenesten, eske 26-35. Notat, «Sovjetiske krigsgraver i Norge». Utenriksdepartementet 03.07.1954. 
svarets side gjort oppmerksom på at kravet om flytting ville bli opprettholdt siden et viktig militært anlegg var prosjektert i nærheten av gravene. Det ble ikke opplyst hva slags militært anlegg dette dreide seg om, men det ble fremhevet at anlegget gjorde flyttingen av gravene nødvendig. I forbindelse med samling av de sovjetiske gravene i Trondheim mente kirkegårdsmyndighetene at den påtenkte samleplassen på Lade kirkegård ikke hadde stor nok kapasitet. Rundt 500 sovjetiske ofre skulle etter planen gravlegges på Lade. Kommisjonen hadde derfor funnet frem til et nytt gravsted på Rotvoll, som lå nær Charlottenlund. De norske representantene i kommisjonen ønsket derfor å finne et tredje sted i eller i nærheten av Trondheim hvor en samleplass kunne legges uten at militære interesser ble berørt. Når det gjaldt gravstedet på Tromøya, mente kommisjonens norske representanter at en ville få problemer med sivilbefolkningen, og det var enighet om ikke å flytte disse gravene. I stedet skulle man forsøke å få området erklært forbudt for utlendinger. Kommisjonen ville kontakte Forsvarsstaben for å be om en bekreftelse angående de militære spørsmålene som ble diskutert på møtet. ${ }^{393}$ Gravene ble likevel flyttet til Lade. 111 sovjetiske graver ble flyttet fra Falstadskogen, Skatval, Værnes, Leinstrand og Charlottenlund og til Lademoen kirkegård. Når det gjaldt gravene ved Charlottenlund, var det planlagte militære anlegget avgjørende for valget om å flytte dem.

393 NHM, 278. Krigsgravtjenesten, dokumentsamling. Notat. Møte i UD den 4.6.53 med den norske delen av den blandete Norsk-Sovjetrussiske krigsgravkommisjon. 05.06.1953. 


\section{Likfunn etter «Operasjon asfalt»}

I årene etter at operasjonen ble gjennomført, ble det funnet stadig flere krigsgraver. Det skulle vise seg at gravene i Karasjok inneholdt både sovjetiske og jugoslaviske ofre. Inger Bjørnsen ved distriktskontoret for krigsgraver i Nord-Norge rapporterte fra flyttingen av ofrene i Karasjok i oktober 1952. Sammen med lensmannen startet hun arbeidet med oppgravingen av to lik i Suosjavrre. Det ene liket var av en russer som angivelig var skutt under fluktforsøk ved en fjellstue. Liket lå i leirjord, og det fantes ingen identifikasjon. Det andre liket var gravlagt i ei myr to kilometer fra fjellstuen og var for det meste gått i oppløsning. Det fantes rester etter en uniformsjakke, en strikketrøye og en bukse. Befolkningen på stedet sa at de ikke visste annet enn at dette var en rømling som ble skutt av tyskerne høsten 1944, men en leiebetjent som var med på oppgravingen, hadde mistanke om at de visste mer enn de ville ut med.

Lensmannen fant senere en rapport som omhandlet henrettelsen. Det viste seg å være en sovjetisk krigsfange som ble angitt av en same da han var på flukt og hadde tatt inn hos ei gammel samekone. Han ble fanget og skutt av noen tyskere som bodde i fjellstuen, og gravlagt i myra. Et par dager senere fortsatte arbeidet med oppgraving av ofrene ved Karasjok tollstasjon. Her var det 23 enkeltgraver. Tre av gravene var merket med trekors, og ifølge tollmester Aronsen var det tre russere som lå begravd der. På korsene var det notert fangenummeret til de døde. På de 20 andre gravene var det ingen merker, og fire av gravene viste seg å være tomme. I en grav ble det funnet to lik. Totalt ble det funnet 17 lik, men nasjonaliteten på disse var det vanskelig å fastslå. Bjørnsen 
ved distriktskontoret for krigsgraver i Nord-Norge antok at dette enten var russere eller tyskere, siden tyskerne hadde fangeleirer for sovjetiske krigsfanger og tyske desertører like i nærheten. Nesten alle likene var inntullet i ulltepper eller treull. Det ble ikke funnet dødsmerker eller andre ting av betydning for identifikasjonen av de døde. Alle likene var gått helt i oppløsning siden de ikke var gravlagt særlig dypt. Likene av fire serbiske fanger ble også funnet. De var skutt og gravlagt i utmarksområder i Karasjok. Seks av ofrene, som ble identifisert som sovjetiske, ble i slutten av oktober 1952 overført til Tjøtta krigskirkegård. Ytterligere en grav ble funnet etter at oppgravingsarbeidet var gjennomført. Offeret var en sovjetisk krigsfange, og liket ble overført til Tjøtta i desember samme år. ${ }^{394}$ De tre som kun var registrert med fangenummer, ble oppført som ukjent i Krigsgravtjenestens lister, siden det på dette tidspunktet ikke var mulig å identifisere navnene ved hjelp av fangenumrene. Alle tre er i dag identifisert ved hjelp av tyske fangekort fra sovjetiske arkiv.

I 1953 rapporterte Sentralkontoret for krigsgraver om likfunn av sovjetiske borgere i Nord-Norge. Likene av ni ukjente sovjetiske borgere var funnet i nærheten av den tidligere gravplassen ved Skafferhullet ved Elvenes. Likene ble funnet på stor dybde under arbeidet med fundamentet til det nye minnesmerket som skulle settes opp på gravstedet. Samtidig ble det rapportert om funn av seks andre ukjente sovjetiske borgere i Nord-Norge. Disse sistnevnte funnene var resultat av en rekke henvendelser fra befolkningen til Sentralkontoret for krigsgraver. Sentralkontoret ba Forsvarsdepartementet om å ordne overføringen av de 15 ofrene til krigskirkegården på Tjøtta. Av praktiske og økonomiske grunner var det viktig å få gjennomført overføringen så raskt som mulig, siden overføringen av andre nasjoners krigsgraver pågikk i Nord-Norge på samme tidspunkt. ${ }^{395}$

I 1981 ble det funnet levninger etter en sovjetisk krigsfange på stedet hvor det hadde vært «russerleir» på Oppdal. Funnstedet var i utmark. Krigsgravtjenesten kjente til at tyskerne gjerne gravla de døde fangene i utmark, og var av samme oppfatning som lensmann og lokalbefolkning om at dette måtte være en krigsfange som var gravlagt i nærheten av leiren. Det ble bestemt at levningene skulle jordfestes på den sovjetiske kirkegården på Oppdal. Etter Krigsgravtjenestens bestemmelser skulle levningene ikke legges i kiste, men pakkes inn i et hvitt klede. «Det ville ikke bli tale om noen ordinær begravelsesseremoni og prest skal ikke medvirke», ble det bestemt fra Krigsgravtjenesten side. En tjenestemann skulle markere begivenheten med en meget kort tale som

394 RA, Krigsgravtjenesten, eske 26-35. «Rapport over flytting av krigsgraver i Karasjok distrikt». Bardu 14.10.1952.

395 RA, Krigsgravtjenesten, eske 26-35. «Likfunn av sovjetiske borgere i Nord-Norge». Sentralkontoret for krigsgraver. Oslo 19.10.1953. 
var passende for anledningen. Etter en telefonsamtale med lensmannen skrev representanten for Krigsgravtjenesten at de hadde fryktet at pressen ville møte opp. Som regel ble den sovjetiske ambassaden informert om slike seremonier,

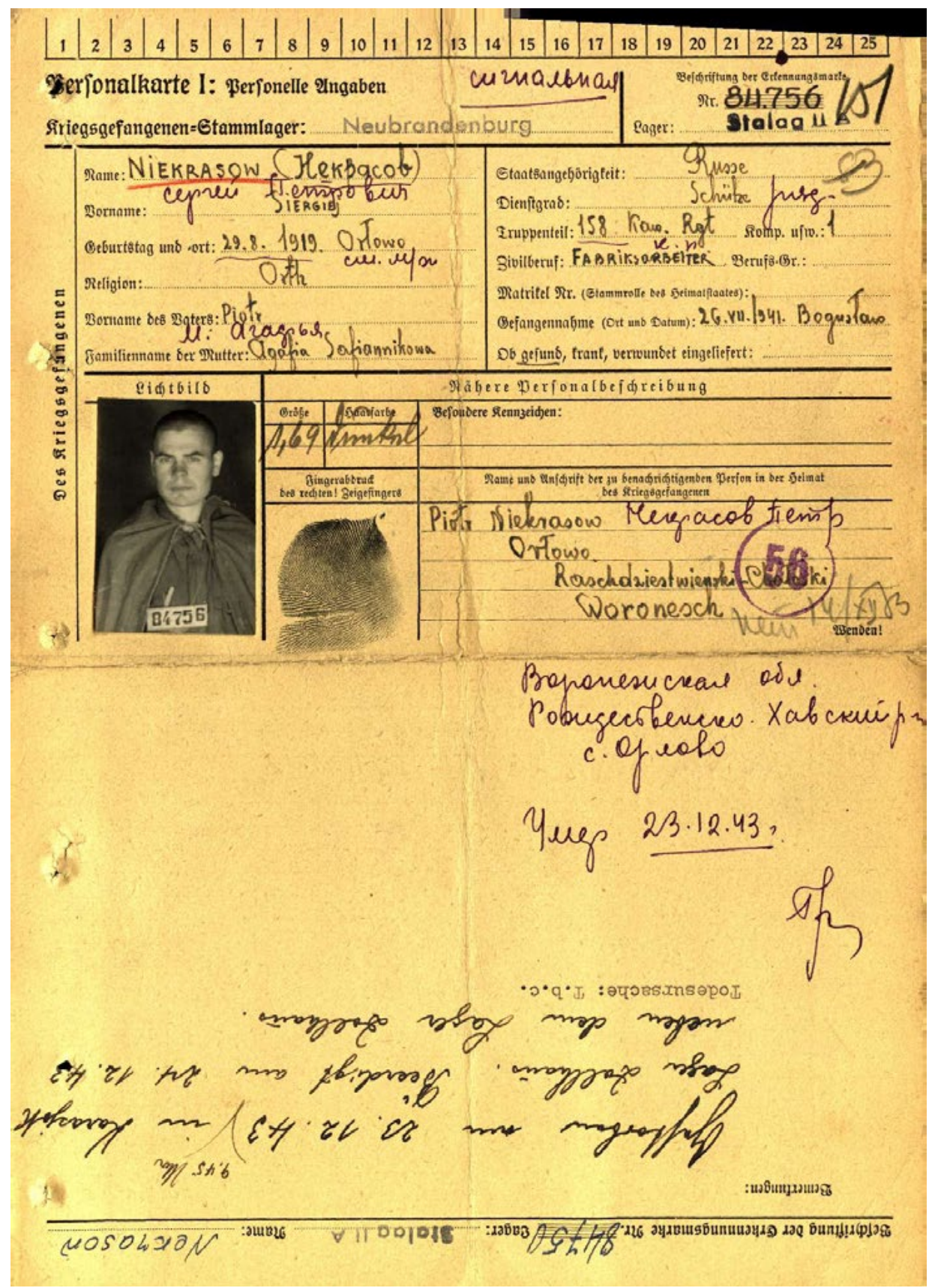

Sergeij Nekrassow, fange i lager «Zollhaus» og gravlagt på den serbiske kirkegården i Karasjok. Foto: www.obd-memorial.ru. 


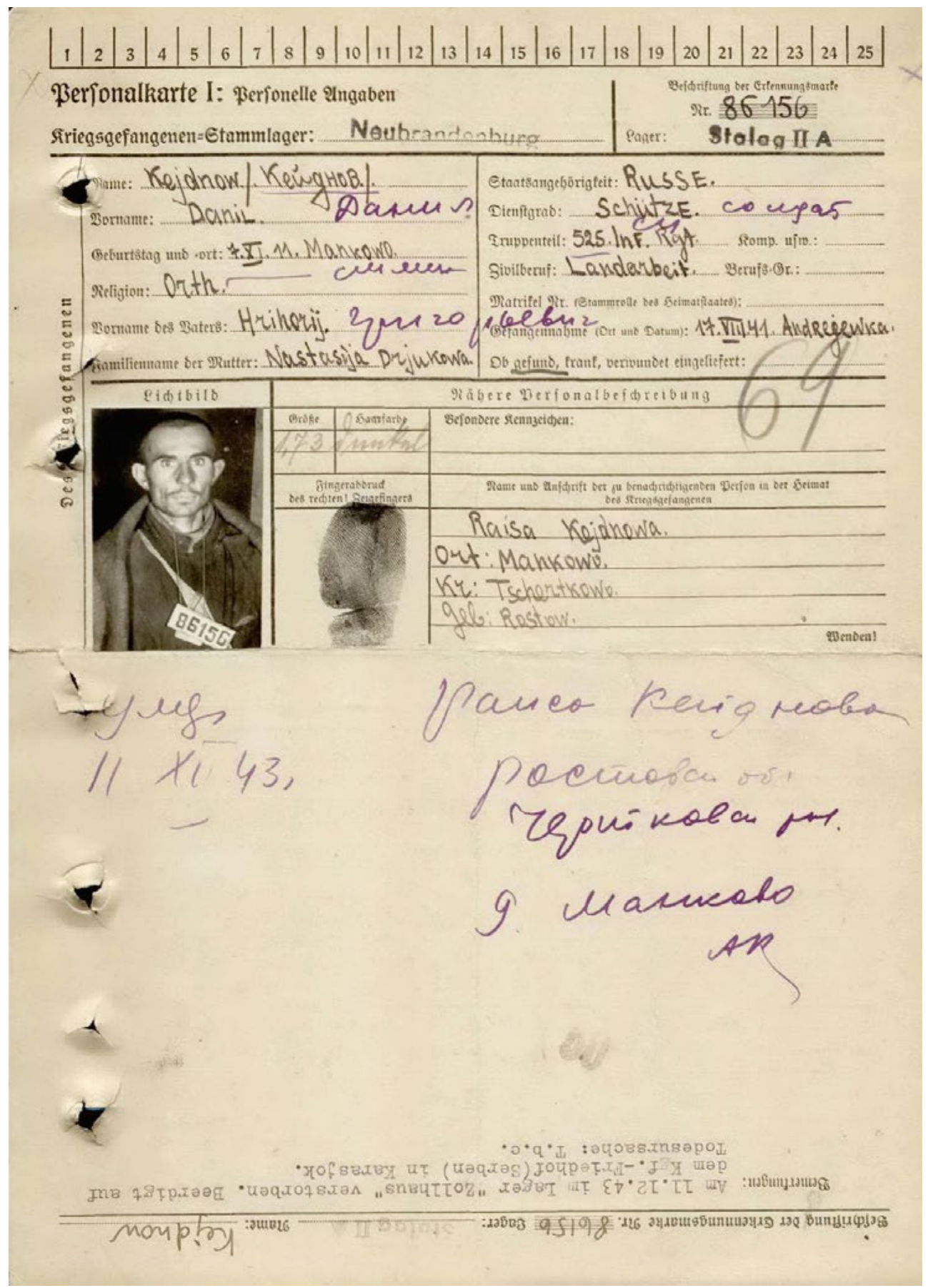

Danil Keidnow, fange i lager «Zollhaus» og gravlagt på den serbiske kirkegården i Karasjok. Foto www.obd-memorial.ru. 


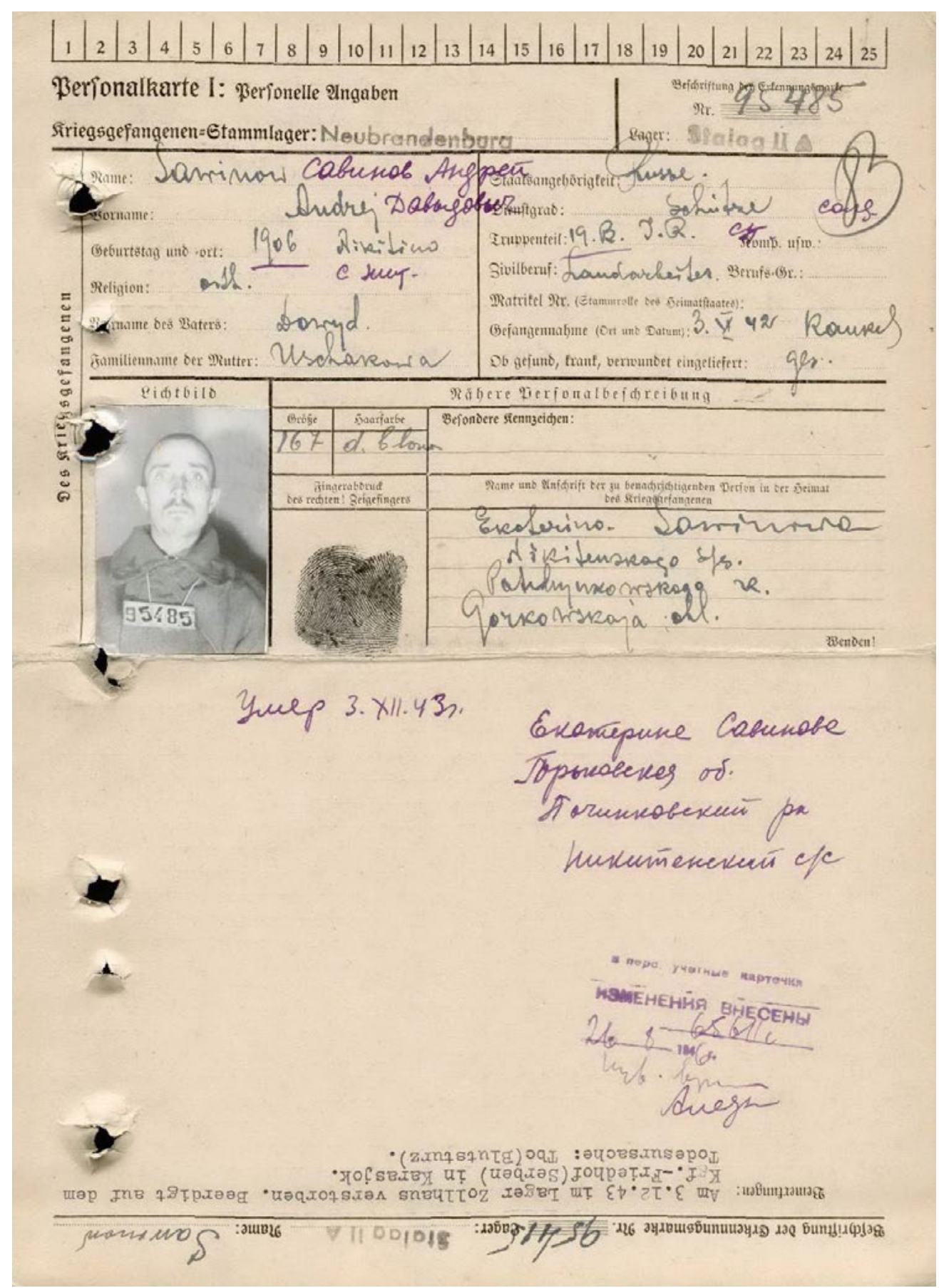

Andreij Sawinow, fange i lager "Zollhaus» og gravlagt på den serbiske kirkegården i Karasjok. Foto: www.obd-memorial.ru. 
men de møtte ikke opp på Oppdal. ${ }^{396}$ En forklaring kan være det kjølige forholdet mellom Norge og Sovjetunionen i begynnelsen av 1980-årene.

Ifølge Krigsgravtjenestens materiale fra 1979 er minnesmerket på Oppdal påsatt en tavle med inskripsjon der det oppgis at 91 ukjente og 13 identifisert ved navn er gravlagt på krigskirkegården. Derfor virker det litt merkelig at 20 sovjetiske krigsfanger som døde på Oppdal i april og mai før frigjøringen, ble navngitt i materiale fra det tidligere Deutscher Oberbefehlshaber Norwegen (DOBN) på Bogstad i Oslo den 8. august 1945. En fange døde ifølge listen dagen etter frigjøringen i $1945 .{ }^{397}$ Hvorfor er ikke alle disse navnene oppført på minnesmerket? En forklaring kan være den dårlige kommunikasjonen mellom de lokale myndighetene på Oppdal og Sentralkontoret for krigsgraver i Oslo. En annen forklaring kan være at norske myndigheter ikke var informert om dette materialet fra tysk side, og at de sovjetiske representantene som befant seg i Norge etter krigen, tok listene med seg tilbake til Russland.

Forsvarets sprengningseksperter har stort sett årlig hatt oppdrag i Sør-Varanger siden krigen. Det har ikke gått et tiår uten at det er blitt gjort funn av døde soldater eller krigsfanger. I 1958 ble det oppdaget en fangegrav med 200 lik ved Elvenes. ${ }^{398}$ Mange av gravene i Sør-Varanger ble funnet ved rene tilfeldigheter i etterkrigsårene, og noen vil nok for alltid forbli ukjente. Sør-Varanger historielag skriver om et likfunn i 1995 da feltgraven til en sovjetisk flyger ble funnet i fjellområdet mellom Bugøyfjorden og Kjøfjorden. ${ }^{399}$ Siste registrerte funn, av 76 graver, ble gjort i september 2014 i Jarfjord i Sør-Varanger. I forbindelse med funnet opplyste Eivind Kosnes at det finnes flere andre massegraver og enkeltgraver rundt om i Sør-Varanger. ${ }^{400}$

396 RA, RAFA-2018/D/Da/D-4. «Funn av hodeskalle m.m. ved graving på grunn hvor det var russerleir under krigen». Krigsgravtjenesten 19.06.1981.

397 http://obdmemorial.ru/memorial/fullimage?id=73120461\&id1=c42fe14e68e02b1342268ad8163b5d8\&path =Z/010/058-0018003-1609/00000291.jpg (Lest 04.04.2013.)

398 Oversikt over sovjetiske krigsgraver i Sør-Varanger under 2. verdenskrig, Sør-Varanger historielags arkiv. Grenselandsmuseet Kirkenes.

399 Sør-Varanger historielag: Sør-Varanger under 2. verdenskrig, arena i stormaktskonflikt. Historielaget, Kirkenes 1997: 154.

$400 \mathrm{http}: / /$ www.sva.no/index.php?page=vis_nyhet\&NyhetID=2476. (Lest 08.06.2015.) 


\section{Identifikasjon av sovjetiske ofre}

\subsection{Fangenummer og fangekort}

Tilgang til nye kilder har gjort det mulig å identifisere flere av de sovjetiske ofrene i Norge.

Denne identifikasjonen av de sovjetiske ofrene er mulig ved hjelp av tyske fangekort som er tilgjengelig i den russiske databasen OBD Memorial (www. obd-memorial.ru). ${ }^{401}$ Fangekortene til dem som ble sendt til Norge, er digitalisert og gjort tilgjengelig for publikum på nettstedet www.krigsgraver.no ${ }^{402}$, utarbeidet av Falstadsenteret, som er et nasjonalt minnested, museum, arkiv og studiesenter. Fangehistorie fra andre verdenskrig, minnekultur, menneskerettigheter og demokrati er sentrale temaer i senterets virksomhet. Etter at den sistnevnte databasen ble publisert, har barn og barnebarn av de døde sovjetiske krigsfangene tatt kontakt med Falstadsenteret for å få svar på hvordan deres slektninger døde og hvor de ligger gravlagt i Norge. Totalt er om lag 5000 ukjente sovjetiske døde identifisert i regi av prosjektet «Krigsgraver søker navn» ved Falstadsenteret i perioden 2009-2011. Prosjektet hadde som mål å finne navnene på flest mulig av de sovjetiske ofrene i Norge og etableringen av nettstedet. Inkludert i antallet som ble identifisert i prosjektet, er 507 som allerede var kjent ved fangenummer og 3534 som var helt ukjente. Per i dag er totalt 6719 av de sovjetiske krigsfangene som døde i Norge kjent

401 Lokalisert på www.obd-memorial.ru.

402 Lokalisert på www.krigsgraver.no. 
ved navn. Flere steder er antallet døde høyere enn det som ble funnet på ulike rettersteder og gravsteder etter krigen. I tillegg kommer ca. 190 navngitte sovjetiske ofre som sannsynlig døde i Norge, men disse tallene er ikke bekreftet.

Et spørsmål vi kanskje aldri vil få helt klart svar på, er hvorvidt de sovjetiske ofrene faktisk ble gravlagt på de ulike stedene som Wehrmachtsauskunftsstelle für Kriegerverluste und Kriegsgefangene (WASt), den tyske gravadministrasjonen, registrerte på fangekortene i krigsårene. I motsetning til gravlegging av krigsfanger av vestlig nasjonalitet ble de sovjetiske krigsfangene fratatt all ære ved sin død. Ofrenes klær ble fjernet og deres kropper ble pakket inn i papir og begravd i all hast. Som oftest, og i motsetning til internasjonale regler, ble ofrenes ID-merke fjernet for å brukes videre til registrering av andre fanger. Alt dette gjør at vi aldri kan være helt sikre på hvor fangene ble gravlagt før de ble flyttet i 1951. Særlig er dette et vanskelig spørsmål i de tilfellene der flere fanger døde på samme dag og kanskje ble lagt $\mathrm{i}$ en fellesgrav uten ordentlig merking av graven. Til tross for dette er fangekortene til de sovjetiske krigsfangene som døde på norsk jord, det beste materialet i arbeidet med å rekonstruere dødsårsak blant fangene og hvor de ble gravlagt i løpet av krigsårene.

Alle sovjetiske krigsfanger ble registrert med et fangenummer på en identitetsbrikke etter at de ble overført til en fangeleir. Deretter ble hver enkelt fange registrert med et fangekort (personalkarte I/PKI). På dette kortet ble krigsfangene registrert med personlige data, opplysninger om overføringer til andre fangeleirer, sykehusinnleggelser og arbeidsavløsning. På baksiden av fangekortet ble det oppført dato og stedsbetegnelse for hvilken fangeleir fangen var sendt til samt dato for dødstidspunkt. Et problem med denne registreringen var at dette ikke ble registrert på samme måte på alle fangekortene. På noen kort er det oppført mye informasjon og detaljer om krigsfangens opphold i ulike fangeleirer, dødstidspunkt og dødsårsak, mens det på andre kort er sparsomt med informasjon. På svært mange fangekort er det ikke oppført dødsårsak, men bare dødstidspunkt. Fangekortet fulgte hver enkelt krigsfange gjennom hele fangenskapet. Det var likevel hver enkelt fanges fangenummer som ble det viktigste kriteriet for identifikasjon. Registrering av en fange ble bare gjort én gang. Samme fangenummer kunne ikke registreres på nytt. Fanger som flyktet, og hadde mistet den opprinnelige identitetsbrikken, ble registrert igjen med et annet fangenummer. Når et fangenummer ble tildelt en fange, kunne det ikke brukes på nytt, selv ikke når fangen døde. På grunn av det store antallet sovjetiske krigsfanger som døde 
vinteren 1941-1942, ble det bestemt at man skulle forenkle prosedyrene for dødsmeldingene, men plasseringen av gravstedet måtte uansett registreres. I midten av 1942 beordret den tyske innenriksministeren at de sovjetiske gravene skulle ordnes på enklest mulig måte. Enkeltgravene skulle merkes med nummerplate og navnene skulle føres opp i egne oversikter over kirkegårdene. Hver krigsfangeleir hadde egne oversikter over informasjonen på identitetsbrikkene. Oversiktene inneholdt opplysninger om fangenummer, for- og etternavn, detaljer om familie og hjemstedsadresse, samt opplysninger om nåværende plassering. Offisiell registrering av personlige opplysninger om krigsfangene var derfor begynnelsen på en kompleks administrativ prosess som bare endte når en krigsfange flyktet fra fangenskap, ble sluppet fri eller døde. Tap av en identitetsbrikke ble alltid rapportert til WASt i Berlin. I WASt ble det i løpet av krigsårene bygd opp et omfattende arkiv med informasjon om døde sovjetiske krigsfanger. Amerikanske tropper kom over arkivet i Meiningen i Thüringen i Tyskland, hvor arkivet ble flyttet i 1943 på grunn av krigshandlingene. Arkivet ble overlevert til Den røde armé i 1945. I dag befinner materialet seg i det russiske forsvarsdepartementets arkiv (TsAMO) i Podolsk utenfor Moskva. Siden 2000 har alle fangekortene blitt digitalisert og all informasjon er lagt ut på databasen OBS Memorial. ${ }^{403}$

Materialet i den russiske databasen består av skannede fangekort fra det tysk-sovjetiske prosjektet «Sowjetische Kriegsgefangene in deutscher Hand» - et prosjekt som er finansiert av tyske myndigheter, og har som mål å systematisere tilgjengelig arkivmateriale om sovjetiske krigsfanger. Ved søk på "Norge» i dette materialet får man nærmere 1000 treff, men en stor andel av de fangekortene som omfatter sovjetiske ofre på norsk jord, er ikke registrert med norske stedsnavn. Derfor må man søke på de ulike samleleirene krigsfangene ble sendt fra før ankomst til Norge. Dette var samleleirer som for eksempel Stalag II B eller Stalag 309 i Salla i Finland. På denne måten har det vært mulig å registrere flere norske stedsnavn knyttet til dødssted og gravsted for sovjetiske ofre på norsk jord. I tillegg gir også noen av fangekortene opplysninger om hvilke arbeidsbataljoner krigsfangene har tilhørt i Norge. Disse opplysningene gjør at vi kan følge fangene fra leir til leir i krigsfangenskapet. Fremdeles er det materiale fra sovjetiske arkiv som ikke er registrert i databasen OBD Memorial, og hver måned blir nye registreringer tilgjengelige i denne databasen.

${ }^{403}$ Otto, Reinhard: «Cemeteries of Soviet prisoners of war in Norway», i Historisk Tidsskrift, nr. 4, 2011: 537-542. 


\title{
6.2 Hva gir fangekortene svar på?
}

Om lag to tredjedeler av de sovjetiske ofrene som ble gravlagt på Jørstadmoen, er registrert med et fangekort (personalkarte I). På disse fangekortene, som for eksempel kortet til Nikolaj Jefimovitsj Belousov, står følgende som regel markert med rød skrift:

\author{
Dødsdato: 12.3 .1944 \\ Dødsårsak: Lungetuberkulose \\ Gravsted: Jørstadmoen \\ Gravnummer: 580 \\ 13. juni 1944 \\ Kaluza, Gefr. (eiter) ${ }^{404}$
}

506 av de 954 sovjetiske ofrene på Jørstadmoen i Oppland er oppført med dødsårsak lungetuberkulose eller tuberkulose. 36 døde av hjertesvikt og 32 krigsfanger døde av en kombinasjon av tuberkulose og hjertesvikt. 30 krigsfanger er registrert med dødsårsak fysisk svekkelse og 15 krigsfanger døde av lungebetennelse. 86 døde av tarmbetennelse og fem av blodforgiftning. Syv krigsfanger ble skutt, de fleste etter fluktforsøk. 101 av ofrene er oppført med ukjent dødsårsak og resten av fangene døde av ulike sykdommer som ble registrert i enkelttilfeller. Eksempler på sykdommer var tarmkatarr, ødem, hjernehinnebetennelse, dysenteri og ulike betennelser.

Antallet sovjetiske krigsfanger var størst i de tre nordligste fylkene Finnmark, Nordland og Troms. Ved hjelp av fangekortene er det registrert at 1118 sovjetiske krigsfanger døde i Finnmark. 65 av krigsfangene døde av fysisk svekkelse på grunn av ulike sykdommer, 29 krigsfanger døde av diaré og 25 av tarmsykdom. 30 krigsfanger døde av svakt hjerte eller hjertestans. 25 er registrert døde av lungetuberkulose og 45 av tuberkulose. 14 krigsfanger døde av forgiftning av alkohol eller ukjent væske. 49 ble skutt på grunn av fluktforsøk, tyveri, arbeidsvegring, motstand eller angrep på vaktmenn. 690 av de registrerte døde sovjetiske krigsfangene i Finnmark er ikke oppført med dødsårsak.

674 sovjetiske krigsfanger er registrert døde i Troms fylke. 35 av disse døde av tarmsykdommer, 30 av svekkelse på grunn av betennelser, 147 døde av svakt hjerte, 37 av sirkulasjonssvekkelse og 54 av fysisk svekkelse på grunn av ulike sykdommer. 20 krigsfanger ble skutt, og seks av disse ble skutt på grunn av fluktforsøk. 261 sovjetiske krigsfanger som døde i Troms fylke, en forholdsvis stor andel, er ikke registrert med dødsårsak.

404 www.obd-memorial.ru. (Lest 10.10.2014.) Fangenr. 16774, Nikolaj Jefimovitsj Belousov, registrert i databasen. 


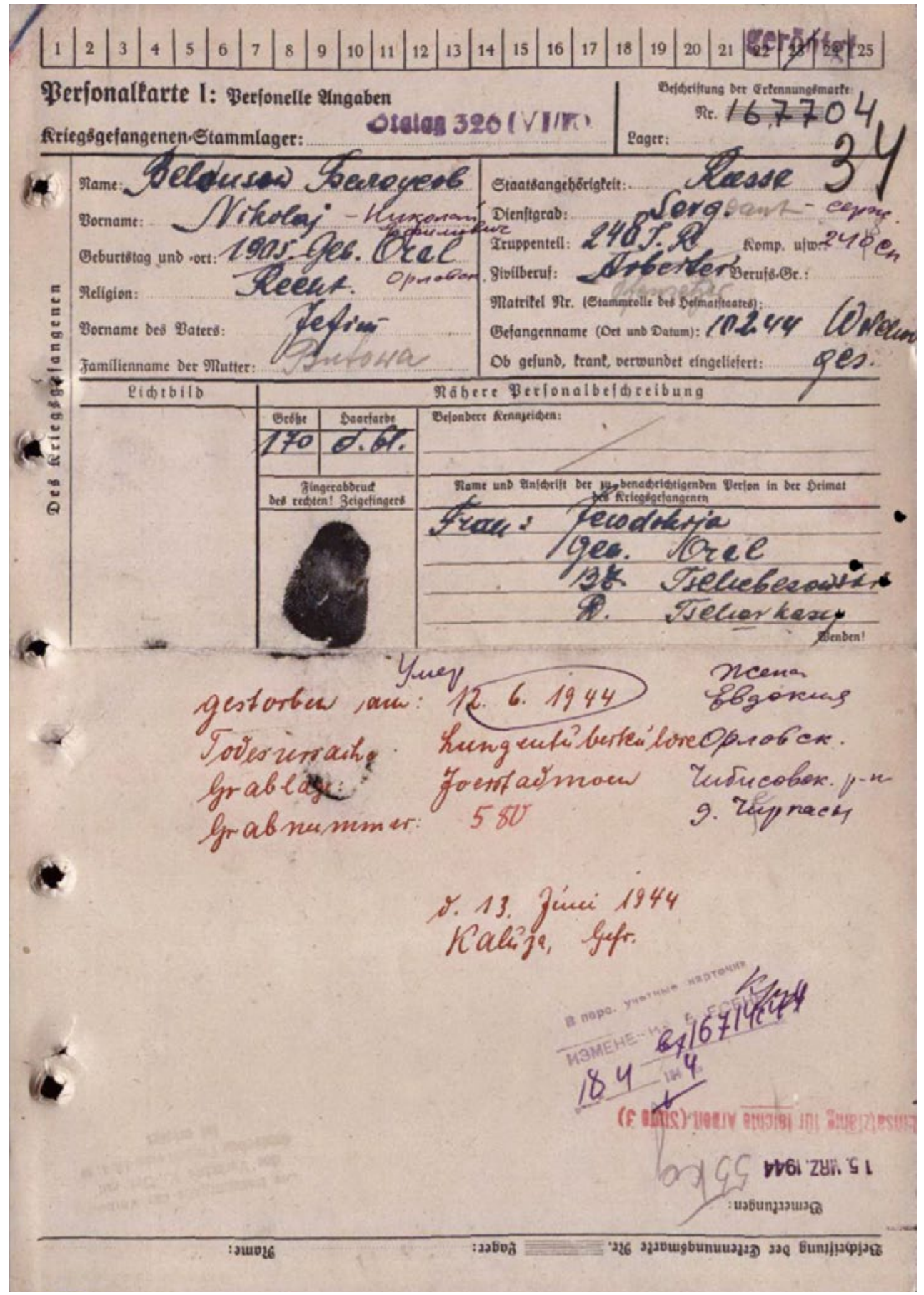

Kopi av fangekort, Nikolaj Jefimovitsj Belousov. Foto: www.obd-memorial.ru. 


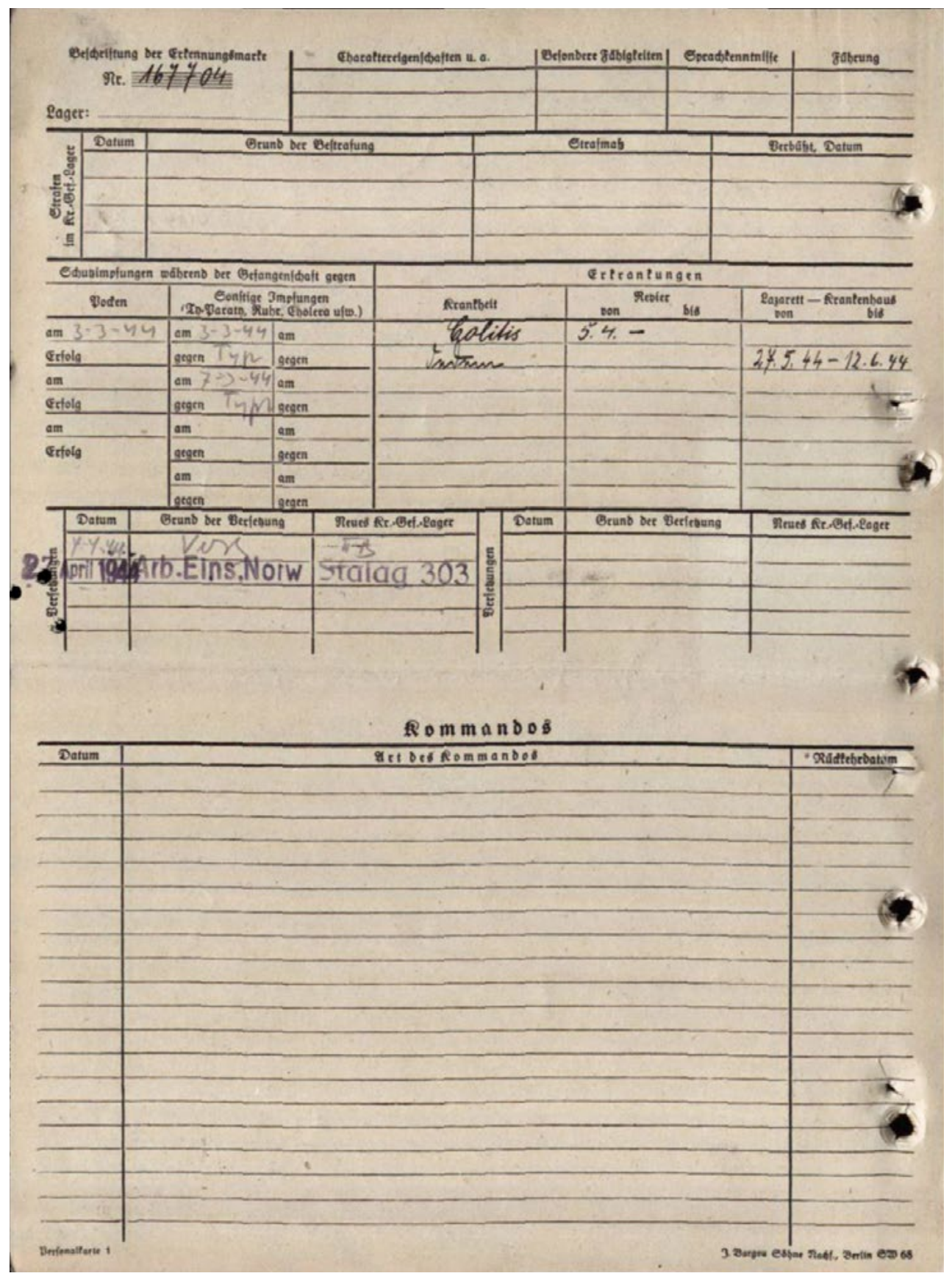

Bakside av fangekort Nikolaj Jefimovitsj Belousov. Foto: www.obd-memorial.ru. 
På Trondenes i Harstad i Troms er det funnet fangekort fra over 398 døde sovjetiske krigsfanger. For 151 av disse er svakt hjerte oppgitt som dødsårsak. 29 er registrert døde av tarmbetennelse og 31 av tarminfluensa. 34 fanger døde av sirkulasjonssvekkelse og 39 av fysisk svekkelse. For 76 av fangene er det ikke oppført noen dødsårsak. De resterende døde av ulike sykdommer eller svekkelse på grunn av sykdom.

I Nordland er det registrert 2276 døde sovjetiske krigsfanger. Fangekortene viser at omtrent halvparten av disse fangene døde av fysisk svekkelse, tarmbetennelse eller tarmkatarr, diaré, svakt hjerte, hjertestans, fysisk svekkelse, lungetuberkulose, lungebetennelse eller tuberkulose. 109 fanger ble skutt av ulike årsaker som flukt, tyveri, angrep på vakter, motstand eller arbeidsvegring. For 967 av de identifiserte sovjetiske krigsfangene i Nordland er det ikke oppgitt dødsårsak.

Et av de større gravstedene i Nordland lå på Engeløya i Steigen kommune. 518 sovjetiske krigsfanger er registrert døde på Engeløya. 511 av disse er identifisert ved fangekort. 249 av disse ofrene er oppført med dødsårsaken «Schwäche» (svekkelse/fysisk svekkelse). Ni av krigsfangene ble skutt av ulike årsaker som tyveri, flukt, fluktforsøk eller motstand. Det var også mange som døde av ulike sykdommer. 30 krigsfanger døde av tarmkatarr og 15 døde av lungetuberkulose eller komplikasjoner i forbindelse med lungesykdom. Åtte krigsfanger døde av lungebetennelse og seks av dysenteri. Bare fire fanger er registrert døde av underernæring, seks av ødem og fem av forgiftning. 123 av de sovjetiske krigsfangene som døde på Engeløya, er ikke registrert med dødsårsak på fangekortet. Det er sannsynlig at det store antallet som døde av svekkelse, også var underernært og utslitt på grunn av hardt arbeid. Viktor Oleksandrovich Petrasjevski overlevde fangenskap på Engeløya og beskriver den som en dødsleir. Fangene ble satt til å bygge brakker, arbeide i et steinbrudd og bygge bunkere. Arbeidet var svært hardt og ernæringen dårlig. I steinbruddet døde det mange mennesker, og man tråkket hele tiden på likene. Petrasjevski forteller at fangene hadde umenneskelige livsvilkår. Tyskerne prylte ofte de fangene som ble kraftløse og uføre på grunn av det harde arbeidet. Det døde svært mange mennesker der, minnes han. ${ }^{405} \mathrm{I}$ juni 1945 trykte avisen Tromsø et innlegg med tittelen «Ny Katyn-historie, denne gang i Nordland. 500 russere skutt, sultet og mishandlet til døde. Nu har de fătt en verdig begravelse». I innlegget ble det fortalt om de sovjetiske ofrene på Engeløya. Tidligere hadde det gått rykter om den bestialske behandlingen krigsfangene var utsatt for av tyskerne i dette området. Fangenes arbeidskraft ble brukt til bygging av festninger til forsvaret av Vestfjorden. Da krigen var

405 Brev fra Viktor Oleksandrovich Petrasjevski til forfatteren, 06.06.2001, oversatt fra russisk til norsk av Viktor Igorovitsj. 
over, samlet medfangene de døde kameratene fra de ulike gravene og ga dem en verdig begravelse på Engeløya. Over graven ble det reist et minnesmerke med følgende inskripsjon på russisk og norsk:

Her hviler 514 soldater fra Den røde arme som langt bak fronten har bukket under på grunn av pinsler og dyrisk mishandling av den tyske fascisme. Hvil i fred kamerater. Deres fedreland og folk som nå er befridd fra den tyske fascisme vil aldri glemme en eneste av dere. ${ }^{406}$

Lensmannen i Steigen rapporterte et halvt år senere at tre av ofrene døde etter å ha drukket frostvæske, mens de andre døde på grunn av mishandling og sult. Den sovjetiske plasskommandanten hadde en fortegnelse over de gravlagte med navn, fødselsår og bosted, men hadde tatt den med seg ved hjemreisen til Sovjetunionen i juni 1945. Ifølge lensmannen hadde ingen i distriktet noen oversikt over navnene på de døde fangene. ${ }^{407}$

F.A. Polentsov overlevde tysk fangenskap i Norge. Som marinesoldat under andre verdenskrig ble han tatt til fange av tyskerne under et forsøk på å befri byen Temrjok. Sammen med en barndomsvenn og regimentskamerat ble han først sendt til Romania og Ungarn, og så gjennom Østerrike til Tyskland. Til slutt ble de sendt til Oslo med skipet «Ulanga» og deretter videre nordover. Om fangeoppholdet forteller Polentsov følgende:

I konsentrasjonsleirene i Norge utnyttet fascistene først vår arbeidskraft til å bygge og omlegge flyplassen ved Trondheim, siden ble vi sendt til det lille stedet Torklen (Torkilseng), som ligger 50-60 $\mathrm{km}$ fra Bodø. Der arbeidet vi med å slå en tunnel gjennom fjellet for jernbanelinjen Trondheim-Narvik. Det harde arbeidet og de umenneskelige livsvilkårene kostet mange av mine kamerater livet. Der, langt fra vår fedrejord mellom noen klipper anla vi en russisk kirkegård. Der i Torklen-bukta mistet jeg også min venn, frontkamerat og følgesvenn fra alle konsentrasjonsleirene. ${ }^{408}$

Ved avreisen hadde lokale myndigheter forsikret de gjenlevende krigsfangene om at gravene til de døde krigsfangene aldri ville bli rørt, og garantert dem om at de ville bli bevart. Polentsov fikk med seg et bilde fra Norge som viste leiren og litt av kirkegården. Bildet ble et svært kjært minne for ham i mange år etter frigjøringen fra tysk fangenskap, og han skriver at: «Alt dette har for

406 Tromsø, 23.06.1945.

407 RA, RAFA-2018/D/Da/L0023. Narvik politikammer. Narvik 08.02.1946.

408 RA, RAFA-2018/D/Da/D-3. «Anmodning fra sovjetisk krigsveteran F. A. Polentsov om fotografier av en krigskirkegård». Den norske ambassade. Moskva 23.11.1967. 
livet brent seg inn i min erindring.. ${ }^{409}$ Polentsov ville gjerne vite hvordan gravene ble tatt vare på og kontaktet derfor den norske ambassaden i Moskva for å få tak i et nytt bilde av gravstedet. Etter kort tid ble jordstyret i Sørfold kommune kontaktet for å skaffe opplysninger om graven til Polentsovs kamerat. Basert på opplysninger fra lokalbefolkningen fant de ut at det hadde dødd en russer på stedet. Han ble først gravlagt på et sted som var så grunnlendt at liket måtte flyttes lenger ned mot sjøen våren etter at han ble gravlagt. Den avdødes kamerater hadde stelt gravstedet, og de støpte et minnesmerke. Etter krigen ble liket fjernet og sammen med de andre sovjetiske ofrene flyttet til Tjøtta. Senere ble gravstedet slettet på grunn av veiarbeid. Traseen til den nye riksveien (E6) ble lagt akkurat der gravstedet var og slettet alle spor. ${ }^{410}$ Eugen Syvertsen ved Krigsgravtjenesten viste til at graven ble fjernet etter krigen og før riksveien ble anlagt da norske myndigheter flyttet de mange midlertidige sovjetiske feltgravstedene som var plassert i utmark, myrer og lignende steder. Syvertsen sendte et bilde av krigskirkegården på Tjøtta til Utenriksdepartementet. Han opplyste at et bilde av graven på Tjøtta kunne skaffes hvis navnet på den døde var identifisert og gravstedet ved flyttingen fra Torkilseng til Tjøtta var merket med den gravlagtes navn. ${ }^{411}$ Polentsov fikk dermed ikke oppfylt ønsket om et nytt bilde av graven på Torkilseng. Det er ingen dokumenter i Krigsgravtjenestens arkiv som viser hvorvidt man visste navnet på den gravlagte krigsfangen.

Historien om de sovjetiske krigsfangenes skjebne i Norge kommer nær inn på oss når identifikasjonen av ofrene gir ny kunnskap til slektninger som i alle årene etter krigen har vært intetanende om hva som skjedde med deres kjære.

70 år etter at Arkadij Semonivitsj Kornetsjik døde på Grønsvik kystfort på Lurøy, fikk datteren hans Galina vite at han døde i Norge i 1942. Faren ble identifisert ved hjelp av fangekortet. Det var også oppgitt at han var gravlagt i grav nummer fire på Selnes i Lurøy. Den 34 år gamle snekkeren Kornetsjik bodde i landsbyen Narovlia i Hviterussland sammen med kone og fem barn i 1941, da det tyske angrepet på Sovjetunionen startet. Bare noen uker etter angrepet ble han tatt til fange av tyske styrker. Han ble etter hvert fraktet til en fangeleir i Gomel i Hviterussland. Hans kone fikk vite at han satt i krigsfangenskap i Gomel. Hun fikk også høre at flere hadde kjøpt slektningene sine fri fra krigsfangenskap, og det ville hun også prøve. Derfor tok hun med seg alt hun hadde av verdisaker og gikk 120 mil for å komme

409 Ibid.

${ }^{410}$ RA, RAFA-2018/D/Da/D-3. «Ad russisk gravsted på Torkelseng». Kvarv i Salten 12.12.1967.

411 RA, RAFA-2018/D/Da/D-3. «Anmodning fra sovjetisk krigsveteran F.A. Polentsov om fotografier av en krigskirkegård». Oslo 17.01.1968. 
til fangeleiren mannen satt i. Dessverre hadde ektemannen blitt flyttet to dager før hun nådde frem til leiren. Han hadde blitt fraktet til Polen før han ble sendt videre til slavearbeid i Norge på Grønsvik på Helgelandskysten. Grønsvik kystfort ble bygd for å beskytte innseilingen til Sjona-, Rana- og

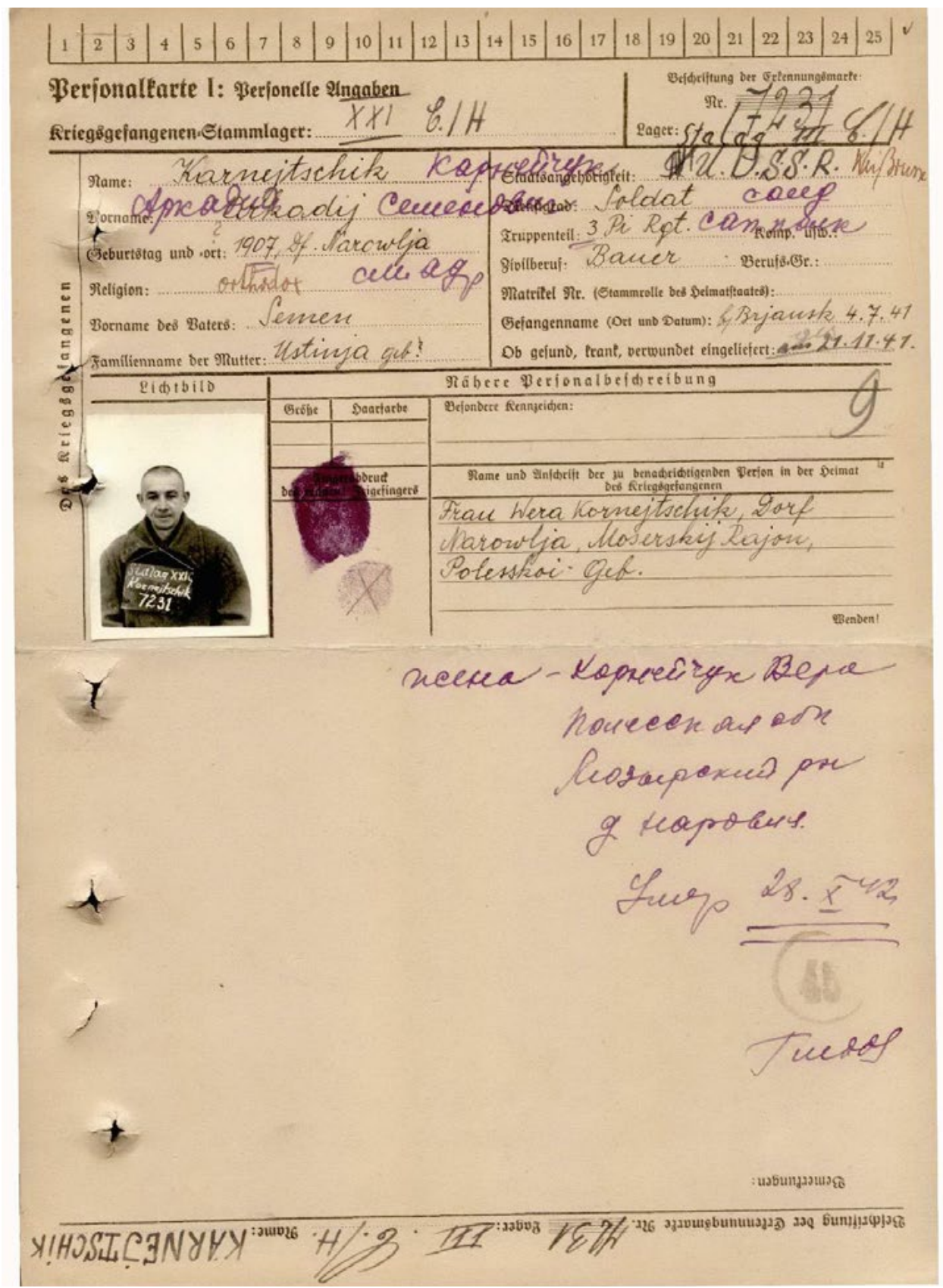

Fangekort, forside, Arkadij Semonivitsj Kornetsjik. Foto: www.obd-memorial.ru. 
Vefsnfjorden. Kystfortet var en del av de storstilte byggeprosjektene til tyskerne under «Festung Norwegen», som ble bygd for å beskytte norskekysten. De sovjetiske krigsfangene bar ut sprengstein fra fjellet, bygde bunkere, veier og lastet opp sand fra fjæra til støpning av bunkerne. Tusenvis av kilometer

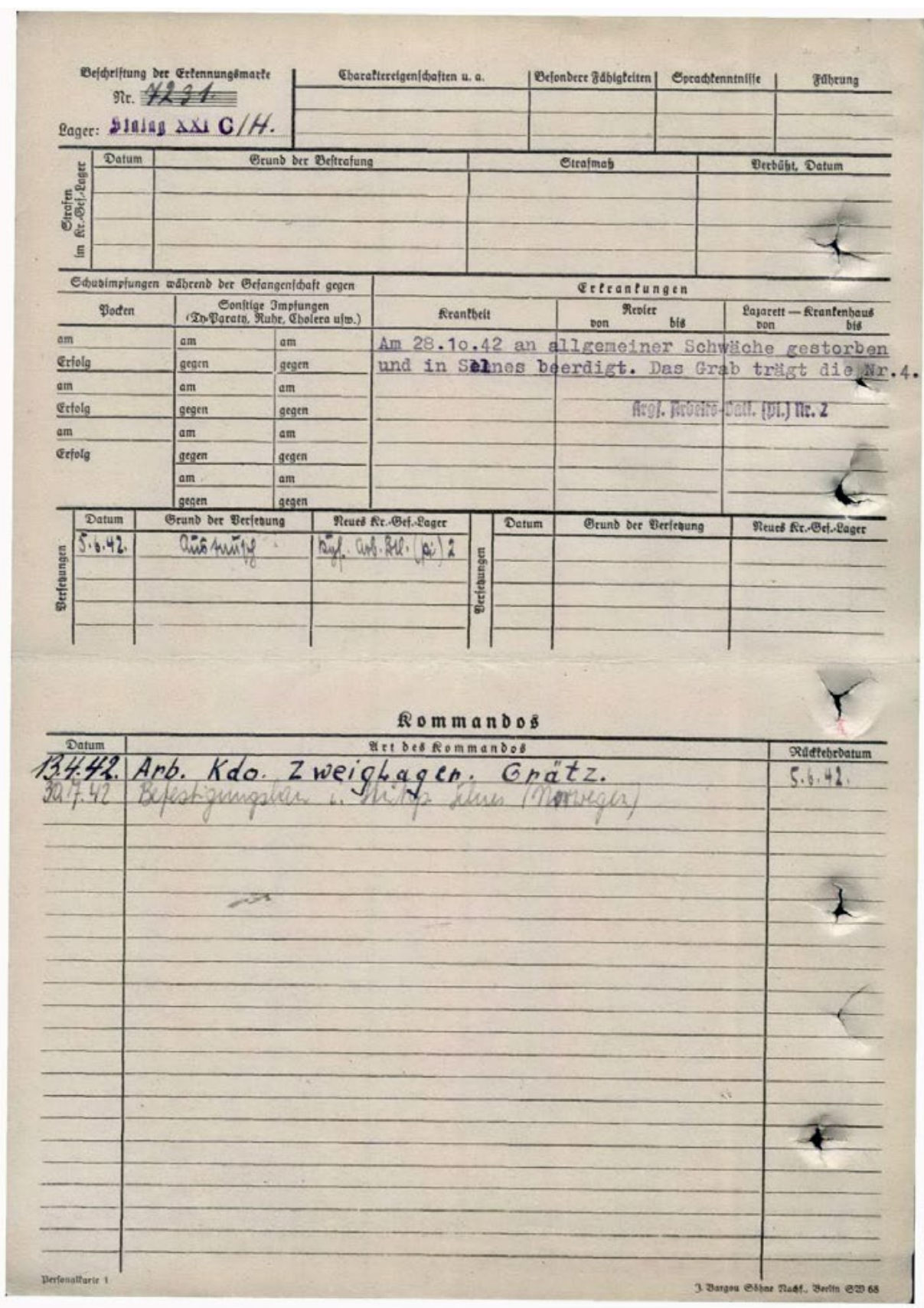

Fangekort, bakside, Arkadij Semonivitsj Kornetsjik. Foto: www.obd-memorial.ru. 
fra hjemstedet døde Kornetsjik til slutt av det harde arbeidet. Han døde av utmattelse tre måneder etter at han ankom Grønsvik fort på Lurøy. Han var utslitt og syk etter å ha blitt utsultet av de tyske vaktene. I krigsfangekortet står det at han «døde av allmenn svekkelse». Etter sin død ble Kornetsjik lagt i en fellesgrav med seks andre krigsfanger. Gjenlevende krigsfanger bygde etter krigen et stakittgjerde rundt graven og satte opp et trekors på graven.

I 1951 ble gravene flyttet under «Operasjon asfalt». Hodeskallene til de døde ble fraktet til krigskirkegården på Tjøtta. Restene av skjelettene lot graverne ligge igjen. Datteren Galina forteller at i alle årene etter krigen trodde familien at faren døde i en leir i Ungarn. At han skulle ligge begravd helt nord i Europa, var nesten ubegripelig for henne. Etter å ha lest en annonse i lokalavisen fikk Galina vite hvor faren var gravlagt. Sammen med svigerdatteren dro hun til Norge sommeren 2012, for endelig å ta farvel ved farens grav. På gravstedet ble det holdt en minneseremoni ved minnesmerket med navnene på de døde. Den ortodokse presten Aleksander Volokhan fra Trondheim ledet seremonien der mange fra lokalbefolkningen og generalkonsulatet i Kirkenes møtte opp. Galina betraktet graven til sin far og holdt hånden på hjertet. «Jeg er glad for at jeg endelig har fått svaret på hva som skjedde med far», sa hun. Galina var glad for at familien endelig hadde fătt visshet og en grav å gå til. ${ }^{412}$

\subsection{Døde på havet}

\subsection{1 «Palatia»}

I 1942 ankom til sammen 20156 sovjetiske krigsfanger til Norge. Et av skipene, «Palatia», ble senket den 21. oktober nær Utvåre øst for Lindesnes. Om bord var det mange krigsfanger som skulle nordover. Det var en Hampden jagerbomber fra Coastal Command/ 489 Squadron Royal New Zealand Air som senket skipet, og flygeren var uvitende om at tyskerne hadde plassert mange krigsfanger under dekk. ${ }^{413}$ Det var 1000 sovjetiske krigsfanger om bord og 885 av disse druknet. ${ }^{414}$

Flying officer Richardson, fra Royal New Zealand Air, oppdaget skipet utenfor Lindesnes. Han la seg i angrepsposisjon og fyrte at en torpedo mot skipssiden rett bak maskinrommet. Richardson måtte trekke raskt opp i skylaget for å unngå luftvernilden og en Junker 88 (tysk kampfly) som var i nærheten. Han så derfor ikke eksplosjonen som flerret «Palatia» i stykker.

\footnotetext{
412 http://www.nrk.no/nordland/fant-farens-grav-etter70-ar-1.8293162. (Lest 28.08.2012.)

413 Stavanger Aftenblad, 22.09.1997.

414 BA/MA, RW 39/v,30, TB, A.O.K Norwegen/O.Qu./Qu. Oktober 1942.
} 
slingring ble kraftigere. Lyset forsvant. Det lyktes meg å få en tysker til å slippe meg ut på dekket. Akterenden sank ned i bølgene og soldatene kastet sine våpen og sprang omkring $\mathrm{i}$ vill panikk. De fylte redningsbåtene og tenkte kun på å redde sitt eget skinn. Jeg ville hjelpe mine kamerater ut fra lasterommet, men det var altfor sent. Fra et eller annet sted i skroget kom det to eksplosjoner med kort mellomrom. Vannet strømmet inn gjennom et hull i skroget. Jeg rakk akkurat å få tak i rælingen og hang over avgrunnen i en høyde av omkring 15 meter. Raskt fikk jeg av meg overfødig tøy og skoene, og deretter hoppet jeg i havet. En redningsvest jeg hadde funnet i lasterommet brakte meg opp til overflaten. Jeg skyndte meg å svømme litt vekk fra skroget mens skipet sank. Etter noen minutter kunne jeg se vrakgods fra skipet og folks hoder omkring. Noen få var kommet opp fra lasterommet. ${ }^{416}$

Svært mange krigsfanger klarte ikke å komme seg ut av skipet. En del ble sugd ned med skipet og en del kunne ikke svømme. Litvintsov berget seg ved at han fikk tak i en redningsbøye av metall. Bølgene var høye og ikke langt unna klamret krigsfanger seg til vrakrester. Etter en stund dukket det opp en kanonbåt, men mannskapet torde ikke å sette en redningsbåt ut i den høye sjøen, men kastet ut livliner. Hvis en russer tok fast $i$ en line før det var hans tur, ble han skutt på kloss hold. Litvintsov forteller:

Jeg advarte kameratene. Jeg fikk øye på en bred fender som hang langs kanonbåten. Jeg fikk en desperat ide. Da en bølge slo mot båten samlet jeg mine siste krefter og fant feste for bena på fenderen og presset meg mot skipssiden. Jeg mistet bevisstheten men ble hengende i tauet på fenderen. En eller annen på dekket fikk tak i hodet mitt og trakk meg om bord, jeg var reddet. Jeg kom til meg selv men kunne ikke stå på bena. Noen tyske matroser slepte meg under dekk. Der var overlevende kamerater nakne og forfrosne.

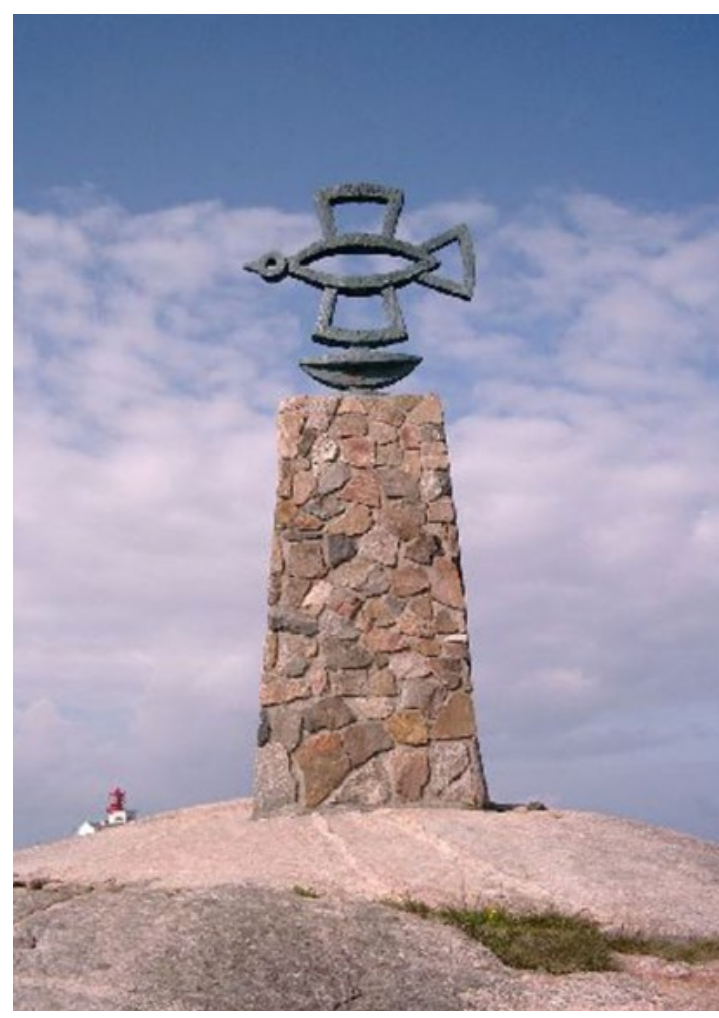

Minnesmerket ved Lindesnes 1997.

Foto: Forsvarsmuseet Oslo. 
Alle hadde merker etter tunge slag. Kanonbåten økte farten og gikk mot land. Der ventet tyskerne med våpen. Ved hjelp av knyttnever og geværkolber fikk de stilt oss opp i rekker. Det var omtrent 160 mann. Klokken var mellom 01.00 og 02.00 om natten. Omsider kom vi frem til utkanten av en by hvor vi ble plassert i brakker bak piggtrådgjerde. Det var uoppholdelig stønn fra syke og sårede og vi kunne ikke slippe de marerittlignende bildene fra båten. Den 23. oktober førte de en blond tater inn, som alle kalte Ivan. I nesten et døgn hadde han holdt ut med sine kamerater på noen vrakrester. Den ene fangen etter den andre døde i brakken. De ble overlatt til seg selv uten noen form for pleie. Likene ble pakket inn i papirsekker og dumpet i havet. ${ }^{417}$

En del av fangene drev i land på Lillehavn og Lindesnes etter forliset. I 1945 ble det funnet ni sovjetiske ofre som var gravlagt på Lindesnes etter forliset. Ofrene ble gravd opp og flyttet til en felles grav på Spangereid kirkegård. ${ }^{418}$

\subsection{2 «Rige|»}

På grunn av den tyske tilbaketrekningen langs kysten av Nord-Norge høsten 1944, lå det i perioder flere allierte hangarskip utenfor kysten. De hadde fly som jaktet på de tyske troppetransportene. Et av lasteskipene som deltok i tilbaketrekningen, var MS «Rigel». Skipet fraktet tyske tropper og materiell fra Nord-Norge. I slutten av november 1944 var skipet på vei sørover langs Nordlandskysten. På denne turen var lasten sovjetiske krigsfanger og tyske desertører. I Bjerkvik utenfor Narvik anløp skipet for å ta om bord 951 sovjetiske krigsfanger og 114 soldater som tysk eskorte. Derfra gikk skipet samme dag uten konvoi til Narvik for å ta imot ytterligere 349 krigsfanger og 149 soldater. Dessuten ble 103 tyske straffanger og 37 soldater til eskorte sendt med skipet. Dagen etter gikk skipet til Tømmerneset med konvoi for å ta om bord 948 sovjetiske krigsfanger og 121 soldater som eskorte. ${ }^{419}$

De allierte visste sannsynligvis ikke at skipet inneholdt et stort antall sovjetiske krigsfanger og tyske straffanger. Mandag 27. november ble «Rigel» angrepet nord for Tjøtta på Helgeland. Angrepet ble utført av fly fra det britiske hangarskipet HMS «Implacable», som lå i havet utenfor Helgelandskysten. «Rigel» ble skutt i brann og deretter satte et tungt bombeangrep inn. Personalet om bord samt de sovjetiske krigsfangene og tyske straffangene var under dekk.

417 http://janss.dk/palatia.php. (Lest 12.05.2014.)

418 RA, RAFA-2018/D/Da/L0023. Rapport. «Russiske soldater - begravet på Lindesnes». Mandal 04.04.1946.

419 Rapport vedrørende M/S «Riegel»s undergang ved fiendeaksjon den 27.11.1944 på høyden av Rösö Nord (Norge). Dokument mottatt fra Trond Carlsen. 


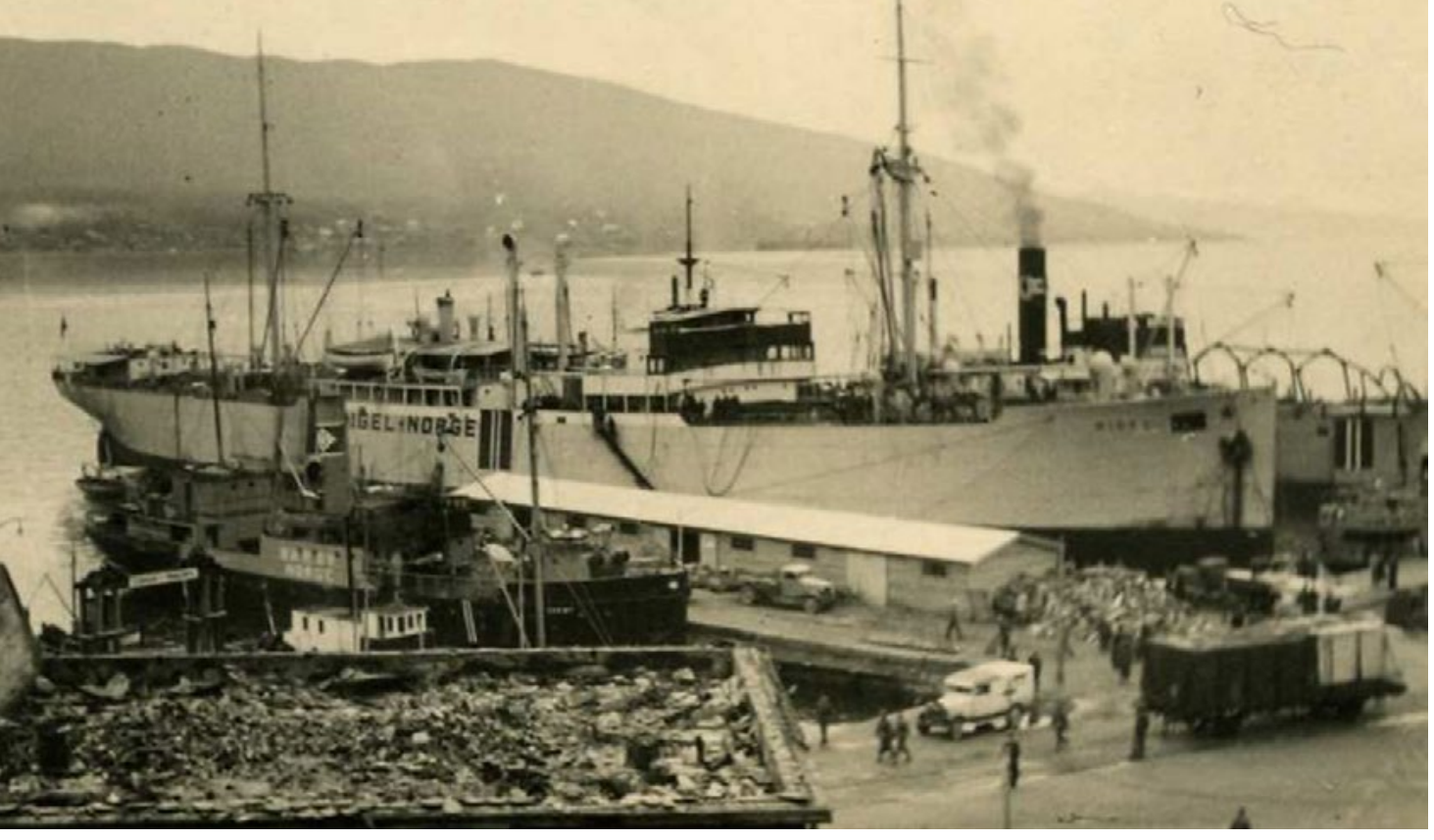

«Rigel» 1940. Foto: Rolf Vanje / Museum Nord.

Beskytningen fra flyene rammet skipet fra alle retninger med en intensitet som det var vanskelig å forestille seg, forklarte kapteinen etter angrepet. To bomber rammet luke I og III. ${ }^{420}$ Flere av bombene eksploderte nede i lasterommene der fangene oppholdt seg. I et forsøk på å redde skip og mennesker satte kapteinen kurs mot land og prøvde å sette skipet på grunn. «Rigel» sank etter en stund og ble stående med bare baugen over vannet. De aller fleste om bord døde nede i lasterommene uten mulighet til å komme seg opp på dekk og videre i land. ${ }^{421}$ Over 2500 av menneskene om bord omkom. Bare vel 250 ble reddet. Kaptein Heinrich Rohde mente at det lave antallet overlevende skyldtes at skipet ble rammet av minst fem bomber og en uhyrlig beskytning fra flyene. Han syntes det var bemerkelsesverdig at også de som klarte å berge seg fra skipet og drev omkring i vannet eller hadde kommet seg i land, ble rammet av intens beskytning fra flyene. Overlevende fant ly på to bondegårder i området, fikk førstehjelp av en norsk lege, en kvinnelig sykepleier og en sovjetisk krigsfange som var sanitetssersjant. Den tyske kapteinen har fortalt at de raskt fikk tak i våpen og assistanse fra seks tyske straffanger til å ta seg av bevoktningen av de 150 overlevende sovjetiske krigsfangene. ${ }^{422}$ Denne skipskatastrofen er en

420 Rapport vedrørende M/S «Riegel»s undergang ved fiendeaksjon den 27.11.1944 på høyden av Rösö Nord (Norge). Dokument mottatt fra Trond Carlsen.

${ }^{421}$ Carlsen, Trond: Rigel. Norgeshistoriens største skipsforlis. Eget forlag, Sandnessjøen 2003: 117.

${ }^{422}$ Rapport vedrørende M/S «Riegel»s undergang ved fiendeaksjon den 27.11.1944 på høyden av Rösö Nord (Norge). Dokument mottatt fra Trond Carlsen. 
Illustrasjonen er å se i trykt versjon 
historie om uvitenhet, meningsløs lidelse og grusomhet med tanke på at krigsfangene ble så hardt rammet. På samme tid er det også en historie om heltemot, hjelpsomhet og medfølelse overfor krigsfangene.

Beboerne på Rosøya og Tjøtta kom raskt til unnsetning med båter og deltok i redningsarbeidet sammen med sanitetsskipet «Monte Rosa». Under senkningen av «Rigel» ble mange drept av bombene fra de britiske flyene eller omkom i brannene som brøt ut. Av fangene var det de sterkeste og de som kunne svømme, som berget seg. ${ }^{423}$ Historien om senkningen av «Rigel» er et av mange eksempler på at krigens ofre ofte er helt uskyldige mennesker. Bortsett fra litt jernskrap i sjøkanten er det i dag ingen synlige spor etter katastrofen den sene høstdagen i 1944.424

«Rigel»-tragedien ble ikke omtalt i norsk presse før etter at krigen var slutt. I korte notiser ble det skrevet om problemer med lik som fløt i sjøen i områdene rundt Rosøya. Først i 1948 hadde lokalavisen Helgelands Blad en lengre artikkel om tragedien. På slutten av 1960-tallet hentet dykkere opp hodeskaller fra vraket av «Rigel». Folk fikk da høre at det lå hundrevis av lik nede i båten, og saken fikk stor oppmerksomhet i media. ${ }^{425}$

Det ble ikke gjort noe med vraket fra Krigsgravtjenestens side siden det ikke forelå offisielle rapporter om senkningen av skipet. Etter at saken ble tatt opp i media, henvendte den jugoslaviske ambassaden i Oslo seg til Utenriksdepartementet og ba om at skipet ble undersøkt. ${ }^{426}$ I mars 1969 ble oppdraget med ilandføring av de omkomne fra skipet gitt til firmaet «Høvding Skipsopphugging» fra Oslo. Oppdraget var tidkrevende og komplisert. De omkomne var spredt over hele skipet. Flesteparten var i akterskipet, som lå på opptil 40 meters dybde. Det ble funnet likrester overalt, mellom vrakrester av skipet og rammer og sperreverk av gamle kjøretøy som var om bord. Vraket måtte rengjøres - alt avfall og last ble fjernet for å få de omkomne ut. Dette ble gjort for at det ikke senere skulle friste sportsdykkere å besøke vraket og forårsake uheldig oppmerksomhet. Før firmaet tok på seg oppdraget, påpekte de at enhver adgang for uvedkommende var forbudt, og de ønsket ingen reportasjer fra arbeidet som ble utført av dem. De var opptatt av at arbeidet skulle utføres ærbødig og hensynsfullt også av hensyn til belastningen på deres egne arbeidere. ${ }^{427}$

${ }^{423}$ Mezentsev, Feodor: I konsentrasjonsleire bak polarsirkelen. Upublisert manus, 1997: 89. Oversatt fra russisk av Asbjørn Hortman.

424 Carlsen, Trond: Rigel. Norgeshistoriens største skipsforlis. Eget forlag, Sandnessjøen 2003: 101.

425 Ibid.: 100.

426 St.prp.nr 141 (1968-69). Om bevilgning under kap. 226. Krigsgravtjenesten, ny post 28. Ilandføring og gravlegging av omkomne krigsfanger.

427 KUD, nr. 1375. «M/S «Riegel» - fjerning av restene etter omkomne krigsfanger». Oslo 08.03.1969. 
I desember 1969 var firmaet ferdig med arbeidet, og levningene etter 1011 savnede av dem som omkom i tragedien, var tatt opp og gravlagt i en fellesgrav på Tjøtta internasjonale krigskirkegård. Arbeidet med gravleggingen pågikk frem til september 1970. De få identitetsmerkene som ble funnet, var tyske og ble oversendt til tyske myndigheter. Personlige eiendeler som ble funnet, var uten betydning for identifiseringen. Eiendelene ble listeført og oppbevart av Krigsgravtjenesten. Kaptein Eugen Syvertsen ved Sentralkontoret påpekte $\mathrm{i}$ et brev $\mathrm{i}$ 1974 at MS «Rigel» var et lastefartøy som var eid av et rederi fra Bergen, men ble beslaglagt av tyskerne og brukt til troppetransport langs norskekysten. Han mente det var rent unntaksvis at skipet den 27. november 1944 ble brukt som fangetransportskip. ${ }^{428}$

428 KUD, 93/74. «M/S Rigel senket 27. november 1944 ved Rosøya, Tjøtta». Oslo 25.03.1974. 


\section{Jugoslaviske og polske ofre}

\subsection{Jugoslaviske ofre i Norge}

Måtte dette beskjedne verk også være en omtale og et minne for dem, kjente og ukjente, som for evig forble på snøføykete blodveier $i$ et vennligsinnet land $i$ det fjerne Nord, og for dem som her, $i$ fedrelandet, $\mathrm{i}$ årevis har ventet og - venter forgjeves. ${ }^{429}$

Dette skrev Cveja Jovanovic i forordet til sin bok Blodveien i 1988. Han overlevde den ufattelige og svært brutale skjebnen som møtte de jugoslaviske krigsfangene i Norge i krigsårene. Boken skildrer hans grusomme reise fra Beograds fengsler til en nådeløs tilværelse i tyske fangeleirer i Norge. Nordmenn ble hjelpeløse vitner til den umenneskelige behandlingen av de jugoslaviske fangene. Norske fangevoktere var også med på å mishandle og drepe jugoslaviske fanger. Håkon Johansen var vitne til brutaliteten fra de norske fangevokterne:

Den behandling som de norske vaktene ga fangene i Botnleiren var av den art at dersom jeg ikke hadde sett det selv, hadde jeg ikke trodd at slikt kunne foregå. At nordmenn kunne behandle vergeløse fanger på den måten, hadde jeg ikke trodd var mulig. ${ }^{430}$

Det er antydet at om lag 100000 jugoslaver havnet i tysk fangenskap under andre verdenskrig. Flere titalls tusen av disse ble sendt rundt om i det

429 Jovanovic, Cveja: Blodveien. Beograd 1988. Forfatterens forord.

430 Ibid.: 152. 
tyskokkuperte Europa, men tusener ble også henrettet i hjemlandet. Okkupasjonsmakten etablerte 34 leirer i Norge for de om lag 4500 jugoslaviske krigsfangene som ble sendt til landet i årene 1942-1945. Ansvaret for leirene var fordelt mellom SS og Wehrmacht. En del av fangene ble sendt på arbeidsoppdrag underlagt Organisation Todt.

\subsubsection{Utryddelsesleirer}

Lengst i nord lå leiren i Karasjok. I slutten av juli 1942 kom det 374 fanger til denne leiren. I transporten fra Bergen hadde det vært 400 mann, men 26 syke fanger var blitt skutt underveis. Leiren ble oppløst i desember samme år. Det var da bare 112 fanger i live. De øvrige fangene var omkommet på grunn av sykdom, sult, mishandling eller de var skutt. De overlevende ble overført til leiren i Osen i Vefsn. I denne leiren var kun femti fanger i live januar 1943 av de 396 som ankom fra andre leirer i juni 1942. ${ }^{431}$

Beisfjordleiren, tolv kilometer sørøst for Narvik, var den største av leirene. I slutten av juni 1942 ankom 900 fanger, og en måned senere ble 300 skutt, angivelig fordi de led av flekktyfus. Dagen før henrettelsene ble de øvrige fangene flyttet til Bjørnefjell like ved riksgrensen til Sverige. Av de 900 som ankom til Beisfjord, tyder alt på at det ikke var mer enn 150 i live etter noen måneder. Leiren på Bjørnefjell ble nedlagt i oktober 1942, og de overlevende ble sendt til leirene i Osen og Korgen. ${ }^{432}$ Nordmenn i Beisfjord ble sjokkerte

431 Jovanovic, Cveja: Blodveien. Beograd 1988: 76.

432 Christie, Nils: Fangevoktere i konsentrasjonsleire. Pax Forlag, Oslo 1972: 51-54. 
vitner til ankomsten av fangene. En lastebåt la til ved Fagernes-kaia. Tyskerne hadde omhyggelig blokkert hele området ved å plassere en ring av soldater rundt det hele. Skipet fikk ned landgangen, og det begynte å strømme ut fanger som klatret ned på kaia. De ble stilt opp i rekker, og like etterpå startet de den ti kilometer lange marsjen til Beisfjord. Fangene var utmattede og magre. Mange var syke. Noen fanger måtte bæres. Fangene hadde fillete klær, og noen manglet sko. Nordmenn som fikk se dette triste synet, reagerte og ga høylytt uttrykk for hva de mente. Tyskerne svarte med å fengsle dem som var mest høyrøstet. Fangene var sivile menn, og noen av dem var svært unge. Behandlingen av fangene var så brutal at det vanskelig kunne beskrives. Nordmennene i Beisfjord følte seg maktesløse. Det var lite de kunne gjøre for å lette lidelsene til fangene. Noen forsøkte å stikke til dem litt mat og klær, men ofte kunne dette ende i piskeslag om det ble oppdaget. ${ }^{433}$

På Bjørnefjell var fangetilværelsen et mareritt med mishandling og drap. En far og hans sønn ble skutt etter at sønnen hadde forsøkt å hjelpe faren da han falt på fjellet. Sønnens bøddel var en hirdvokter, knapt et par år eldre enn den drepte gutten. Vokteren kastet kaldblodig geværet på skulderen og fortsatte å rope på andre. Faren til den drepte gutten knelte foran den unge hirdvokteren og ba han skyte ham også, men han gikk bort fra stedet uten å se på den ulykkelige faren. Til slutt ble faren skutt av en SS-vakt. En medfange som hadde vært vitne til drapene, klarte knapt å fortelle om det som skjedde på fjellet. Den brutale behandlingen fortsatte, og fanger ble mishandlet med stokker eller kvalt. En norsk sjåfør som var med på transporten fra leiren i Beisfjord til Bjørnfjell, var rystet over behandlingen av fangene:

Innlastningen av fangene foregikk på den måten at de norske og tyske vaktene gikk med kjepper eller gevær og med disse slo eller stakk fangene dersom de ikke var rappe nok til å komme seg inn i bilen ... Fangene var såre og forslåtte oppover beina og kroppen. På mange var føttene svært opphovnet ... Det var 600 fanger som ble kjørt opp ... De ble slått av norske vakter eller av tyske dersom de var nærmere ... Den behandlingen som samtlige norske vakter gav fangene var rå og umenneskelig. Det finnes ikke ord som er sterke nok til å karakterisere den behandling som de norske vaktene uten unntakelse gav fangene. Jeg spurte nede på kaien hva disse fangene hadde gjort når de fikk slik behandling. En av de norske vaktene sa at dersom jeg visste hva disse karene hadde gjort, så klaget jeg ikke over behandlingen som de fikk ... Jeg hadde et bestemt inntrykk av at de norske vaktene likte å behandle fangene på den måten som de gjorde. ${ }^{434}$

${ }^{433}$ Mladenović, Ljubo: Beisfjordtragedien. Grøndahl \& Søn Forlag A/S, Oslo 1989: 11-12.

${ }^{434}$ Christie, Nils: Fangevoktere i konsentrasjonsleire. Pax Forlag, Oslo 1972: 53. 
Etter oppholdet på Bjørnefjell ble de overlevende fangene sendt tilbake til leiren i Beisfjord. I leiren fant fangene sykebrakken nedbrent og et vannbasseng brukt som massegrav. Brutaliteten og drapene på fanger fortsatte på samme måte etter at fangene kom tilbake til Beisfjord. 23 syke fanger ble kastet ut av brakkene og skutt av norske og tyske vakter. ${ }^{435}$

Botnleiren, nær Rognan i Saltdal, var i drift fra juli 1942 til juni 1944. Tallene er ikke fullt ut bekreftet, men antakelig var det 472 fanger i leiren da den ble opprettet. Mer enn halvparten av fangene omkom i den tiden nordmenn var fangevoktere i leiren. Da de norske vaktene forlot leiren, ankom 300 nye fanger direkte fra Jugoslavia. Etter frigjøringen ble det i Botn funnet 356 døde jugoslaviske fanger. Sør for Saltfjellet lå leirene i Osen og Korgen. En transport på 800 fanger som ankom Trondheim i juli 1942, ble fordelt med halvparten i hver av disse leirene. Kort tid etter ankomst ble 40 fanger i Korgen og 20 fanger i Osen skutt som represalie for at to fanger hadde drept en tysker og deretter rømt. Leiren i Osen ble oppløst i 1943 og resten av fangene ble overført til Korgen. ${ }^{436}$

Dragan Jovanović overlevde fangenskapet i Botn og forteller at alle fangene ble tvunget til å melde seg frivillig til ekstra arbeid. Han meldte seg til arbeidet med å grave graver og gravlegge de døde, og forteller hvorfor han valgte dette:

Det var roligere å arbeide der. Tyskerne lot deg være alene der. Ellers, hvis du for eksempel valgte å bære ved ville de være rett ved siden av deg, og jage og slå deg ofte. Jeg valgte arbeidet på kirkegården selv om det i begynnelsen var en forferdelig jobb. Vi var flere grupper som arbeidet med å gravlegge de døde. Da antallet døde økte jobbet vi annenhver dag på kirkegården. Jeg jobbet ellers med gravearbeid og det døde et større antall fanger under dette arbeidet. Hver dag måtte vi slepe en eller to døde kropper tilbake til leiren fra arbeidsstedet. ${ }^{437}$

Alle disse nevnte leirene i Nord-Norge må karakteriseres som rene tilintetgjørelsesleirer hvor formålet var systematisk å utrydde samtlige fanger ved sult, mishandling og hardt arbeid.

En norsk fangevokter fortalte i avhør i mai 1945 om behandlingen av de jugoslaviske fangene i Osen i Elsfjord (Vefsn):

Der var forferdelig med dysenteri i leiren og de fleste som var angrepet var döde da vi kom. Fem a seks dödsfall i døgnet hadde det vært i lengre tid og dette fortsatte i ca. 14 dager etter vi var kommet. Der

\footnotetext{
435 Jovanovic, Cveja: Blodveien. Beograd 1988: 92.

436 Parelius, Nils. «Tilintetgjørelsesleirene for jugoslaviske fanger i Nord-Norge. Spesielt om leiren i Botn", i scertrykk Saltdalsboka 1984: 2.

${ }^{437}$ Falstadsenterets arkiv, intervju med Dragan Jovanović, Serbia 2010.
} 


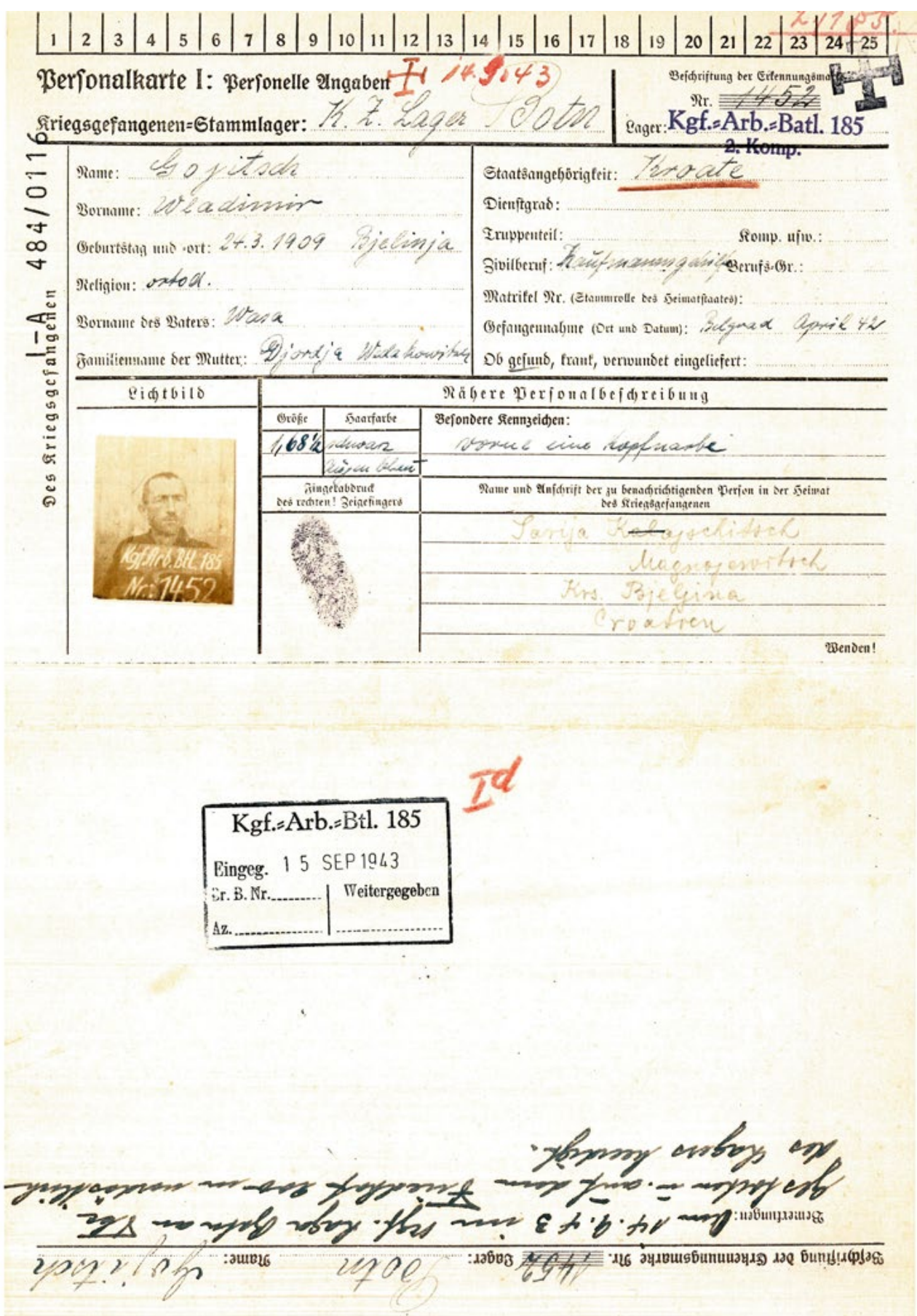

Fangekort, kroatisk krigsfange, død i Botn 14.09.1943. Arkiv: Deutsche Dienststelle. 
var da død ca. 150. De hadde en medisinsk professor som fange. Han behandlet fangene, men det ble sagt at han fikk lite og hjelpe seg med. De som döde ble gravd ned i dynger og kastet et lag jord mellom hvert lag lik. Det ble tatt ut en tilfeldig av vaktmennene til nedgravningen av de som stod nærmest porten om morgenen og resten måtte serberne selv besörge. Jeg hörte ikke om at der ble skutt noen. Derimot ble der skutt fanger i Korgen. ${ }^{438}$

Forklaringen til den norske fangevokteren viser den uverdige behandlingen av fangene og at sykdom krevde svært mange liv.

I 1947 stod en norsk fangevokter tiltalt for sin brutale behandling av serbiske fanger i leiren i Osen. Retten nedla påstand om dødsstraff for vakta. Under rettssaken kom det frem at han hadde utført jobben som vaktmann med stor nidkjærhet og brutalitet. Han slo fanger med geværkolben og med stokker. Ved en anledning skjøt og drepte han en serber fordi fangen gikk ut av kolonnen for å plukke opp en kålrot. Fangen døde på stedet. ${ }^{439}$ Dommen for vaktmannen ble satt til livsvarig tvangsarbeid og rettighetstap i ti år. Ved avgjørelsen hadde retten lagt vekt på den tiltalte vaktmannens unge alder - han var 20 år da dette hendte - og at han ikke hadde hatt moralsk kraft nok til å motstå tyskerne. Ved utmålingen av straffen la retten dessuten særlig vekt på tiltaltes iver i tjenesten som fangevokter, hans ufattelige råskap og den aktive krigstjenesten senere som frontkjemper. ${ }^{440}$

En annen norsk fangevokter forteller i avhør om hva som skjedde i Korgen etter at en tysk vaktmann ble funnet drept ved arbeidsstedet utenfor leiren:

Etter at Rediess hadde reist ble antakelig Dolpen tilbake i leiren, for noen dager etter ble 40 serbiske fanger utpekt av kommandanten Hesse og Dolpen. Fangene ble ført ut og bak leiren hvor de ble skutt av 10 tyske politimenn som var kommet fra Mo i Rana. Da skytningen av disse fanger foregikk måtte de øvrige fanger stå å se på. Før de 40 fangene ble skutt ble de kommandert til å grave en grav like ved leiren. Etter at de var skutt ble en del av de gjenlevende fanger kommandert til å bære likene og kaste dem i graven og senere kaste jord over. Alt dette stod jeg å så på fra ett av vakttårnene, undtatt selve skytningen som jeg ikke kunne se da den foregikk bak brakkebygningen.

I samme avhør fortalte fangevokteren at han hadde inntrykk av at alle fangene ønsket seg fra Korgen, og når de øynet en sjanse for flukt, var det ikke til å undres over at de kunne drepe vakten som forsøkte å hindre det. ${ }^{441}$ Brutaliteten var grenseløs i leiren i Korgen. En sivil nordmann var vitne til at en norsk fange-

438 SAT, Helgeland politikammer. «Fangeleire». Avhør den 25.05.1945.

439 Nordlands Folkeblad, 14.03.1947.

440 Nordlands Folkeblad, 18.03.1947.

441 SAT, Helgeland politikammer. «Fangeleire». Avhør. Mosjøen 29.05.1945. 
vokter sparket en fange i hodet så han døde. Ved et annet tilfelle hadde fangene blitt kollektivt straffet. Fangene måtte da stille opp til appell og ble kommandert til «Hinlegen». Dette betød at fangene måtte ligge dels oppå hverandre og med ansiktet ned i bakken. De som rørte seg, ble skutt. I 16 harde timer måtte fangene ligge på denne måten. Da de endelig ble kommandert til å reise seg, var flere av fangene døde. En av fangene hadde i flere timer ligget med en død kamerat på ryggen. Nesten daglig ble det gjennomført massehenrettelser i leiren i Korgen. Det skjedde særlig den første tiden. Ti-tjue og ikke sjelden flere fanger ble plukket ut og skutt ved kanten av massegravene. Det skjedde ofte at fanger ble skutt under arbeid. I disse tilfellene ble ofrene gravlagt i veikanten. Veioppsynsmann Grønmo i Osen fortalte at de fantes 15 slike graver på strekningen Korgen-Elsfjord, og han hadde vært vitne til alle drapene. ${ }^{442}$ En tredje norsk fangevokter fortalte i sin egen rettssak om de uhyggelige detaljene fra brutaliteten i fangeleiren i Korgen. Vitner i rettssaken beskrev den norske vaktmannen som brutal. Han hadde slått fangene med geværet, kalt dem banditter og skreket «los, los» til de utslitte fangene som segnet om av behandlingen. Under rettssaken satt den tiltalte vaktmannen uberørt og fortalte om sin tjeneste ved leiren i Korgen. Han ble dømt til syv års tvangsarbeid og rettighetstap i ti år. ${ }^{443}$ Fangevokteren mente at tyskerne behandlet fangene godt. Det var av sine egne de fikk det verst, mente han. Leirpolitiet eller "kaupas», som de ble kalt, var mye verre enn tyskerne, fortalte han. En fra leirpolitiet slo sine serbiske medfanger med ei fjøl i hodet for å få dem hurtigere inn eller ut av brakka. ${ }^{44}$

Etter hvert som leirene for jugoslaviske fanger i Troms og Finnmark ble nedlagt, ble nye leirer etablert i Nordland. De nye leirene ble plassert i Krokstrand, Bjøllånes, Sandnessjøen, Lund og Ylvingen. Det ble også etablert nye leirer på samme tid som tyskerne gjennomførte tilbaketrekningen fra Finnmark høsten 1944. Dette gjaldt leirene på Nesna, Pothus og Polarsirkelen. Ingen døde i leiren på Nesna, og i november 1944 ble alle fangene herfra flyttet til leiren på Polarsirkelen. Leiren i Pothus ble etablert i mai 1944 og bestod i hovedsak av overlevende fanger fra leirene i Korgen, Karasjok, Beisford, Osen og Bjøllånes. Senere i juni ankom overlevende fra Botn og grupper fra andre leirer.

I Midt-Norge ble det etablert leirer flere steder etter tre skipsanløp til Trondheim i juni og oktober 1944. Leirene ble etablert på Stenvikholmen, Trolla, Strinda, Austråt, Bretting, Hasselvik, Hovde, Øysand, Rotvold, Persaunet og Falstad. Leiren på Falstad var underlagt SS, og jugoslaviske fanger ble sendt hit i hovedsak som straff for fluktforsøk fra andre leirer i området.

442 Arbeider-Avisa, 15.08.1945.

443 Nordlands Folkeblad, 28.02.1947.

444 Nordlands Folkeblad, 25.02.1947. 
I Sør- og Vest-Norge ble det etablert leirer for jugoslaviske fanger i Lillehammer, Bergen, Rjukan, Porsgrunn og Asker. Disse tre sistnevnte leirene var styrt av Organisation Todt. Leiren i Bergen var midlertidig oppholdssted for fangene før de ble transportert til ulike leirer i Nord-Norge. 120 fanger arbeidet ved tungtvannfabrikken på Rjukan. Alle ble flyttet til leiren i Asker ved Oslo etter at fabrikken ble ødelagt av norske sabotører. På samme måte som de sovjetiske krigsfangene ble også jugoslaviske krigsfanger registrert med fangekort. Et slikt fangekort, som tilhørte Milivoj Pajić, viser at han ble sendt til flere fangeleirer i Norge. Han ble i juni 1943 sendt fra fangeleiren i Korgen til Øysand på grunn av sykdom. En måned senere ble han sendt videre sørover til det tyske sykehuset på Lillehammer og deretter tilbake til leiren på Øysand utenfor Trondheim. Han døde til slutt av tuberkulose på en sykestue på Rotvoll i Trondheim den 15. juni 1944 og er registrert som gravlagt på Rotvoll. I fangekortet er han registrert som serbisk krigsfange tilhørende Stalag 303 (samleleir for krigsfanger) på Lillehammer.

Før ankomsten til Norge var mange fanger samlet i den beryktede leiren Jamiste utenfor Beograd. Forholdene der kan knapt beskrives. I april 1942 startet deportasjonen av jugoslaviske fanger fra leirene og fengslene i Jugoslavia. Fangene ble transportert via Wien til Berlin og deretter til Stettin med tog. Fra Stettin ankom de med skip til norske byer ved ni ulike anløp i tiden juni 1942 til april 1943.

Ifølge tyske transportlister ble 4268 jugoslaviske fanger sendt til Norge. Rundt 90 prosent av fangene var av serbisk opprinnelse. Det dreide seg om politiske fanger, hvorav mange hadde kjempet som partisaner. Det var folk fra alle samfunnslag og med ulik politisk oppfatning. Fangene var i alle aldre, helt ned til gutter i 13-14-årsalderen. Blant fangene befant det seg også kriminelle. Dette var fanger som opprinnelig satt inne på livstid for drap. I de norske leirene ble flere av disse kriminelle en plage for sine medfanger. En del av disse fangene gikk over på tysk side og fungerte tidvis som voktere i leirene og på arbeidsplassene. I tillegg drev de også som angivere.

Fra de første jugoslaviske fangene ankom Norge i juni 1942 og til april/ mai 1943 hadde de ikke status som krigsfanger. Jugoslavia hadde ikke underskrevet Genèvekonvensjonene om krigsfangers status og rettigheter, og derfor ble de heller ikke behandlet etter reglene i konvensjonen. ${ }^{445}$ I denne perioden ble fangene holdt i leirer som var underlagt SS og ble bevoktet av Hirden. Våren 1943 ble fangene, etter press fra Røde Kors, anerkjent som krigsfanger etter ordre fra overkommandoen i Wehrmacht. Behandlingen av fangene ble betydelig bedre etter at Wehrmacht hadde overtatt ansvaret.

${ }^{445}$ I 1943 ble de jugoslaviske fangene anerkjent som krigsfanger av Oberkommando der Wehrmacht. En ordre som viser dette er blant annet Keitels ordre av den 08.07.1943, RW 41/13. 
Barskt klima, høye fjell og store avstander gjorde håpløsheten total for de jugoslaviske fangene i Nord-Norge. Skitt, lus, dårlige klær og lite mat gjorde dagene til sammenhengende mareritt.

I årene 1942-1943 døde om lag 70 prosent av fangene i leirene i NordNorge. Arbeidet var vanvittig tungt, maten minimal og klærne elendige. Fangene hadde ingen kontakt med hjemlandet eller med Røde Kors i disse årene. Innkvarteringen av fangene var svært dårlig, og mishandlinger og drap hørte til dagsorden. Ikke noe sted i Nord-Norge kunne sivilbefolkningen etter krigen fortelle om leirer der fangenes livsvilkår var noenlunde tilfredsstillende. Det var svært dårlig hygiene i leirene. Brøt det ut epidemi, var isolering og utryddelse av de smittede de eneste alternativene.

På Bjørnefjell var det i starten ingen brakker, og fangene ble satt til å grave en kanal rundt et område de måtte oppholde seg på. Emil Magdic oppga at på «Dødsberget» ble ca. hundre og sytti kamerater skutt, forslått med stokker eller kvalt i løpet av en måned fra 19. juli til 22. august i $1942 .{ }^{446}$ Etter tre uker uten innkvartering for fangene ble det satt opp såkalte finskebrakker. Rundt 15 fanger ble plassert i disse små runde brakkene.

I Osen beskrev en norsk gårdbruker hvordan fangebehandlingen hadde vært:

Jeg så selv fanger som var så utmattet av sult og pint på så barbariske måter at de ikke lenger kunne reise seg. De ble da sparket og tråkket på av vaktmannskapene med sine jernbeslåtte sko. Dette ble utført av så vel norske som tyske poster. ${ }^{447}$

En jugoslavisk lege ankom leiren i Botn i oktober 1943 og ga følgende beskrivelse av forholdene i leiren:

Det var mer enn 400 jugoslaviske fanger (...) $50 \%$ av fangene kunne neppe gå, så svekket var de av sult og sykdom. En rekke hadde skabb. I sykehusbrakken lå det ca. 40 pasienter, hvorav 15 hadde tuberkulose i meget fremskredent stadium, andre pasienter lå med ubehandlede benbrudd og en med kjevebensbrudd. Alt medisinsk tilsyn ble gitt av en ung jugoslavisk medisinsk student, men det fantes nesten ikke medikamenter eller instrumenter av noen art. ${ }^{448}$

Legen fremførte sine klager da en general fra Oslo utførte leirinspeksjon, og etter dette ble forholdene mye bedre i leiren. Matrasjonene økte, og legemsstraff ble forbudt. Leiren fikk også forsyninger med medisinsk utstyr.

446 Jovanovic, Cveja: Blodveien. Beograd 1988: 91.

447 Ibid.: 80.

448 Parelius, Nils: «Tilintetgjørelsesleirene for jugoslaviske fanger i Nord-Norge. Spesielt om leiren i Botn", i scertrykk Saltdalsboka 1984: 10. 


\subsubsection{Norsk hjelp og fanger på flukt}

Over hele Norge, men særlig i nord, var det mange nordmenn som hjalp fangene, med fare for selv å bli tatt. Maten fangene fikk av sivilbefolkningen og den de fant på ulike gjemmesteder, var for mange nødvendige bidrag i kampen for å overleve. Navnene på hjelperne, Kirsten Svineng («Mamma Karasjok»), Julia Johansen («Serbiske mor») og Kristian Rugås («Onkel»), ble velkjente blant de overlevende fangene. Fortellingene om innsatsen deres var mange både i Norge og Jugoslavia.

I Karasjok ble fangene jaget ut i elva for å vaske seg mens vaktene kastet stein mot dem. Ifølge Cveja Jovanovic hadde lokalbefolkningen sympati for fangene:

På den andre elvebredden står folk, samer - kvinner og menn og barn, de ser på bading til helt nakne skjeletter, ser på oss med medlidenhet, undres og går bort med å se opp mot himmelen. For denne himmelen, disse breddegradene og dette folket hadde aldri før sett slik bading i iskaldt vann og blod. ${ }^{449}$

På Ørlandet var det vanlig at de jugoslaviske fangene ofte stakk av fra leirene og arbeidsplassene for å skaffe seg ekstra mat og kanskje litt klær fra gårdene. Denne trafikken startet allerede høsten og vinteren 1942-43. Enkelte ble nærmest gjengangere på noen gårder. I ettertid har det vist seg at en del av disse fangene var kriminelle. Men også senere under krigen, da vaktholdet ble mindre strengt, var det forholdsvis vanlig med gårds- og husbesøk av alminnelige partisanfanger.

Når en rømling fra en leir kom utmattet og svak til et hus for å be om hjelp, var det farlig å avvise ham, men enda farligere å hjelpe ham. Etter tysk "Verordnung» ${ }^{450}$ (forordning) risikerte enhver som hjalp krigsfanger, dødsstraff eller å bli sendt til konsentrasjonsleir. Det var ikke så enkelt å tilby hjelp til en fange under flukt. Likevel var de i flertall, de som overvant angsten for fengsel og død, og som hjalp fangene bak piggtråden og dem som klarte å rømme. En fortvilet krigsfange på flukt trengte hjelp av mange slag: husly, litt klær og skotøy, skiutstyr, mat og en los videre til nye kontakter - en slektning, eller en pålitelig nabo eller venn. Det fantes organiserte og sikre fluktruter med grenseloser og etterretningstjeneste, men nordmenn hjalp også fanger som rømte uorganisert på egen hånd, og som hadde satset på tilfeldig hjelp underveis.

For de rømte fangene var det nødvendig med grenselos. Og loser fantes det overalt for de jugoslaviske leirene mot øst. Der hvor de tyske patruljene var aktive og tallrike, var det desto mer nødvendig med los. Hjelp til

449 Jovanovic, Cveja: Blodveien. Beograd 1988: 27.

450 Dagbladet, 04.10.1941. 
flyktende fanger ble av losene betraktet som en kamp mot nazismen, og alt arbeid måtte utføres i største hemmelighet.

Mislykkede fluktforsøk endte som oftest med døden for rømlingene. I 1942 forsøkte en fange å rømme fra arbeidsstedet ved fangeleiren i Botn. Avtalen var at han skulle prøve å komme seg over grensen til Sverige for å fortelle hvordan fangene ble behandlet. Fangen ble innhentet og forsøkte å skjære halsen over på seg med en ståltråd uten at det lyktes. To norske vakter mishandlet fangen på det mest brutale, og han måtte gå tilbake til leiren. Han satt i leiren i tre dager uten mat og vann, inntil han ble hengt $i$ alles påsyn. Han var blå over hele kroppen av alle slagene og sparkene han hadde fătt, fortalte en av hans kamerater som var med på å ta ham ned fra galgen. ${ }^{451}$

Natt til 22. oktober 1943 greide Petar Krasulja, Jovan Stefanovic og Dragoljub Djordevic å klippe seg gjennom piggtrådgjerdet på Falstad fangeleir. Med god hjelp fra folk på Ekne og Markabygda i Skogn lyktes det de tre å komme over til Sverige. Etter krigen kunne de vitne om at mange serbiske og sovjetiske krigsfanger fra Austrått og Ørland hadde blitt henrettet i Falstadskogen i løpet av den tiden de selv hadde vært fanger på Falstad.

I november 1943 rømte Zivota Piric, Josip Dagovic, Dervis Imamovic og Mile Mitrovic fra leiren i Korgen. Nordmenn hadde bedt Piric vente til været bedret seg, men han sa: «Vi må ta sjansen nå! I morgen kan noen av oss være skutt.» Neste dag gikk «Onkel» Rugås langs veianlegget og smilte. ${ }^{452}$ Fangene forstod at det var han som stod bak flukten. Beregninger har vist at 176 jugoslaviske fanger rømte fra leirene i Norge, og at om lag halvparten av fangene nådde friheten i Sverige. De resterende ble enten henrettet eller sendt i leir igjen. Etter frigjøringen ble de om lag 1700 overlevende fangene sendt til oppsamlingsleiren på Melhus. Deretter ble de puljevis sendt hjem til Jugoslavia sommeren og høsten 1945.

Høsten 1946 ble 34 tyske krigsforbrytere, som hadde deltatt i vaktholdet i de jugoslaviske leirene i Norge, stilt for militærretten i Beograd. Foruten vitneforklaringer avgitt av tidligere fanger ble det også dokumentert forklaringer fra norske øyenvitner. Av de tiltalte ble $22 \mathrm{~d} ø \mathrm{mt}$ til døden ved skyting, mens de øvrige fikk fengselsstraffer fra fem til 20 år. Av de som ble dømt til døden, hadde 17 tjenestegjort i en eller flere av de fem opprinnelige leirene i Nord-Norge. Blant dem var også de fem SS-offiserene fra Botn som ble dømt for massakrene i november 1942 og januar 1943. Tre av disse offiserene hadde også tjenestegjort i Beisfjordleiren. Rettsoppgjøret mot de norske fangevokterne strakte seg over et betydelig lengre tidsrom. Det er

451 Parelius, Nils «Tilintetgjørelsesleirene for jugoslaviske fanger i Nord-Norge. Spesielt om leiren i Botn", i scertrykk Saltdalsboka 1984: 6.

452 Jovanovic, Cveja: Blodveien. Beograd 1988: 139. 
antatt at 363 nordmenn tjenestegjorde i leirene for jugoslaviske fanger i Nord-Norge. Av disse vaktene ble $21 \mathrm{~d} ø \mathrm{mt}$ for å ha tatt livet av i alt 25 fanger. ${ }^{453}$ Det ble avsagt to dødsdommer for drap på fanger, begge i 1947. Begge dommene ble omgjort, den ene til 14 års tvangsarbeid og den andre til tvangsarbeid på livstid. ${ }^{454}$

\subsubsection{Gravene}

Det er reist 15 minnesmerker for jugoslaviske ofre i Norge, de fleste i NordNorge. Fremdeles er det graver med jugoslaviske ofre som ikke er lokalisert. Ved Øvre Jernvatn i Narvik kommune antas det at over 140 ofre fremdeles har sin grav i området rundt leiren.

Flesteparten av de jugoslaviske ofrene i Nord-Norge er gravlagt ved den jugoslaviske krigskirkegården i Botn i Saltdal. På samme område er det også satt opp et monument til minne om de sovjetiske krigsfangene som døde der. Laura Vinsrygg opplevde fangene på nært hold i krigsårene og skildret sine inntrykk i menighetsbladet for Saltdal like etter krigen:

Vi som såg desse folka då dei kom hit, vi måtte seia: Dei klarer det aldri, vinteren her i Saltdal, under polarsirkelen. Her gufsar det frå Ishavet, her leikar nordljoset over himmelen i lange mørke døger. Dei kom frå det solljose Serbia, frå dei rike jordbruksslettene ved Kaukasus og Volga. Klimaforandringa, papphusa, potetsuppa, klefillene, vegarbeid i mange kuldegrader og austasno og snø - $\mathrm{A}$ nei, det var ikkje å vente. Men hugse skal vi som såg på deira liding utan å kunne hjelpe stort: Dei fall på ærens mark, desse også. Kvar ukjend krigsfange, utan namn og heimstad på det vesle trekorset, har i dag foreldre i live, kone, born eller sysken. Kvar veit vi ikkje, men dei syrgjer over han som aldri kjem heim att frå krigen. Det er nok mange som hadde hatt hug til å vere saman med oss her $\mathrm{i}$ denne nord-norske skogen i dag. ${ }^{45}$

Dette vitner om en sterk sympati for de jugoslaviske og sovjetiske fangenes skjebne og deres minne.

Sognepresten i Karasjok skrev til Sentralkontoret for krigsgraver i 1947 om krigsgravene i området. Ifølge sognepresten var størsteparten av ofrene serbiske fanger, som døde i krigsfangenskap. Hvor mange serbiske fanger som døde, var han ikke sikker på, men sognepresten antok at det var omkring 300. Serberne var ca. 400 da de kom til Karasjok sommeren 1942, men da

453 Ibid.: 219.

${ }^{454}$ Parelius, Nils: «Tilintetgjørelsesleirene for jugoslaviske fanger i Nord-Norge. Spesielt om leiren i Botn», i scertrykk Saltdalsboka 1984: 13-14.

455 Vinsrygg, Laura: «Krigskyrkjegarden», i Saltdalsboka 1996: 85. 
de reiste sent utpå høsten samme år, var det, så vidt en kunne se, bare ca. 90 igjen. Det var lite kjennskap til dødsårsak blant fangene, men han oppga at mange var skutt, mens andre omkom av sult, frost og mishandling. Serberne var gravlagt i en fellesgrav utenfor kirkegården. Ved en tidligere anledning hadde sognepresten foreslått at det skulle opprettes en egen krigskirkegård. Hvis de serbiske ofrene ikke skulle graves opp i et forsøk på å identifisere noen av dem, foreslo sognepresten at gravstedet ble inngjerdet og innviet til krigskirkegård. ${ }^{456}$ Det ble ikke etablert en krigskirkegård i Karasjok og de serbiske ofrene ble flyttet til krigskirkegården i Botn. I dag er det en egen jugoslavisk minnelund på den tidligere gravplassen i Karasjok.

På Leinstrand utenfor Trondheim ble det funnet en gravplass for både jugoslaviske, sovjetiske og polske ofre. Gravplassen var gjengrodd med store trær og gravene lå delvis under og rundt trærne. På gravstedet ble det funnet 124 jugoslaviske ofre som ble overført til Moholt jugoslaviske kirkegård. I tillegg ble 39 sovjetiske og to polske ofre funnet. De sovjetiske ofrene ble overført til et samlested på Vinjeøra og de polske ble overført til det polske gravfeltet på Moholt. På Leinstrand var det hverken massegraver eller fellesgraver. Hvert offer var gravlagt i enkeltgraver, og opptegnelsene som fantes om gravplassen, stemte relativt godt med de faktiske forholdene. ${ }^{457}$

I utkanten av Trondheim, på Charlottenlund krigskirkegård, ble det i 1953 gravd opp både jugoslaviske og sovjetiske ofre. Samtlige ofre var gravlagt i kister, og alt på gravplassen var svært velordnet. Totalt ble 28 jugoslaviske og 13 sovjetiske ofre gravd opp. De jugoslaviske ofrene ble overført til Moholt kirkegård og de sovjetiske til Lademoen kirkegård. ${ }^{458}$

Sommeren 1942 ankom 400 jugoslaviske fanger til leiren i Korgen. 40 fanger ble henrettet kort tid etter at de var kommet dit. En tysker var drept av to fanger som senere hadde rømt. Henrettelsene var represalier. På samme tid ble også 20 fanger henrettet i naboleiren Osen. Serberen R.R. ga etter krigen en forklaring om forholdene i Korgen. Han fortalte:

(...) de som skulle skytes ble tatt ut. Skytingen ble foretatt av tyskerne. Det var 38 mann som ble skutt. De to som var skutt på plassen ble reknet med i de 40 som skulle skytes. Jeg var ikke med og grov ned de som var skutt, men jeg satt inne på brakken og så på. Jeg hørte av mine kamerater at det var noen av de som ble gravet ned som ikke var døde enda, men de ble gravet ned likevel. Selv så jeg ikke dette. ${ }^{459}$

456 RA, RAFA-2018/D/Da/L0024. «Krigsgraver». Karasjok sokneprestembete. 11.08.1947.

457 RA, Krigsgravtjenesten, eske 26-35. «Gravplassen Leinstrand». Udatert Oslo desember 1953.

458 RA, Krigsgravtjenesten, eske 26-35. «Charlottenlund». Udatert Oslo desember 1953.

459 Christie, Nils: Fangevoktere $i$ konsentrasjonsleire. Pax Forlag, Oslo 1972: 55-56. 
Den jugoslaviske gravplassen i Korgen lå på en liten høyde. Gravplassen hadde et minnesmerke og fellesgravene var markert. Forsvarsdepartementets oppgaver over antall begravde var basert på antagelser, for det ikke fantes sikre fortegnelser over hvem og hvor mange som lå begravd på denne gravplassen. Sivilbefolkningen visste lite om hva som hadde foregått da området hadde vært avsperret omkring krigsfangegravplassene i Korgen. Da Gorduskompaniet på oppdrag fra Sentralkontoret for krigsgraver gjennomførte oppgravingen av de jugoslaviske ofrene i Korgen, oppdaget de at tyskerne hadde gravlagt de døde uvanlig dypt. Gravene var mellom 2,5 meter og 3,25 meter dype. Under arbeidet med oppgravingen forble spørsmålet om hvorfor de døde var gravlagt så dypt, ubesvart. Alle de døde var lagt i fellesgraver, og ofrene lå $\mathrm{i}$ flere lag. Noen av gravene var det naturlig å betegne som massegraver. En del av ofrene var henrettet ved skudd i hodet. Den siste fellesgraven ble tatt opp den 5. november 1953. Da arbeidet var ferdig, ble 205 lik overført fra gravplassen på Fagerlimoen i Korgen til den jugoslaviske krigskirkegården i Botn i Saltdal. ${ }^{460}$ Norske veiarbeidere som hadde arbeidet sammen med de jugoslaviske fangene på riksveien over fjellet mellom Korgen og Elsfjord, antok at nærmere 300 jugoslaviske fanger ble drept i dette området. Alle ofrene som ble funnet, hadde ukjent identitet, og ifølge en melding fra sognepresten i Hemnes var dette politiske fanger. Han opplyste at fangene døde som følge av usanitære forhold, dårlig stell, sult, sykdom og brutal mishandling. En del var skutt eller henrettet som straff eller som represaliehandlinger. ${ }^{461}$

Den største graven som ble funnet, lå i Knutlia i Eldsfjord ved Korgenfjellet. Ifølge Gorduskompaniet ble det i 1953 funnet rester etter 435 jugoslaviske krigsfanger her. Dette var betydelig mer enn det antallet man hadde regnet med lå gravlagt her. Gravstedet var plassert ved Korgenfjellet og nærmest i utmark. Stedet var svært dårlig inngjerdet og bevokst med gress og små trær. Ved første øyesyn så gravfeltene ut til å være godt markert og i tilsynelatende overensstemmelse med gravene. Det viste seg imidlertid at markeringene var foretatt på et senere tidspunkt, og gravfeltene var på helt andre steder enn hva markeringen viste. Gravfeltene i Knutlia var ikke dype, men likene lå i mange lag oppå hverandre. Det var tydelig at tyskerne bare hadde kastet ofrene i graven uten jordlag mellom. Det var ikke mulig å skaffe opplysninger utover det man visste eller kjente fra før om gravfeltet. Lokalbefolkningen hadde ikke hatt anledning til å følge med på hva som hadde skjedd, eller hvordan henrettelsen og gravleggingen hadde foregått.

${ }^{460}$ RA, Krigsgravtjenesten, eske 26-35. «Konsentrering av jugoslaviske krigsgraver i NordNorge. Gravplassen Korgen». Udatert Oslo desember 1953.

${ }^{461}$ RA, RAFA-2017/Y/Yd/L0179. «Jugoslaviske krigsgraver i Norge». Sentralkontoret for krigsgraver. Oslo, Frognerleiren den 08.02.1955. 
Alle ofrene som ble funnet, ble gravd opp og flyttet til den jugoslaviske krigskirkegården i Botn. ${ }^{462}$ I likhet med fangene fra Fagerlimoen arbeidet fangene fra Knutlia på veien over Korgenfjellet. Sentralkontoret for krigsgraver mottok ved oppgravingen i 1953 opplysninger om 283 navngitte døde jugoslaviske fanger fra de overlevende fangene ved Knutlia.

Gorduskompaniet startet oppgravingen av jugoslaviske ofre på gravplassen i Brennhei (Nordland) i desember 1953. Det ble brukt gravemaskin i arbeidet, og etter hvert ble mannskapet mer og mer forbauset over at de fant så få rester etter jugoslaviske ofre. Til slutt ble det konstatert at de hadde funnet levninger etter 16 jugoslaviske døde krigsfanger. Det så ut til at gravstedet hadde vært tømt tidligere. Etter å ha snakket med lokalbefolkningen fikk de bekreftet sine mistanker. Lokalbefolkningen kunne fortelle at da de sovjetiske gravene skulle tas opp fra samme gravsted, mente man at det lå gravlagt 200 sovjetiske ofre der. Det var sannsynlig at det ikke var så mange som 200 sovjetiske døde på dette gravstedet, og at en del jugoslaviske ofre hadde blitt gravd opp som antatt sovjetiske. Etter at oppgravingene var ferdig, ble de jugoslaviske ofrene sendt til Botn. ${ }^{463}$ Det er ikke oppgitt hva som ble gjort med saken angående misforståelsen rundt nasjonaliteten til ofrene.

I Tromsdalen overfor Tromsø kontaktet Gorduskompaniet presten og kirkevergen for å få klarlagt hvor gravfeltet var plassert på kirkegården. Gorduskompaniet ble raskt klar over at Forsvarsdepartementet opererte med et annet tall over ofre enn det som var oppført i kirkebøkene på stedet. Det offisielle tallet på ofre ifølge kirkebøkene var 45, men ved oppgravingen ble det funnet 47 ofre. Ofrene lå delvis i kister, de lå tett i tett som i massegraver, og var sannsynligvis flyttet dit fra et annet sted. Det viste seg også at graver var fylt igjen med store røtter og trær som det var vanskelig å få flyttet. Ifølge listene fra departementet skulle det være ni ofre i kister og 19 uten kister. Det ble funnet elleve ofre i kister og 36 uten kister. Det knyttet seg en del usikkerhet til ofrenes nasjonalitet. Dette skyldtes at noen av ofrene var iført

${ }^{462}$ RA, Krigsgravtjenesten, eske 26-35. «Konsentrering av jugoslaviske krigsgraver i NordNorge. Gravplassen Korgen». Udatert Oslo desember 1953.

463 RA, Krigsgravtjenesten, eske 26-35. «Brennhei». Udatert Oslo desember 1953. 
uniformer fra tyske Wehrmacht og den tyske marinen. Lokalbefolkningen fortalte at en del av ofrene var jugoslaviske skipsmannskaper som nektet å delta i kampene på østfronten og derfor var blitt skutt. Ingen av ofrene hadde noen form for identifikasjon. Det var heller ikke mulig å fremskaffe informasjon om hvordan fangene var fraktet til Storsteinnes utenfor Tromsø, og hvor de kom fra. Mye av årsaken til dette var at opplysningene som ble samlet inn om ofrene, sprikte så mye at Forsvarsdepartementet ikke fant det hensiktsmessig å registrere dem ytterligere. ${ }^{464}$

Ostoja Kovačević, som overlevde den fryktede leiren i Botn ved å rømme til Sverige, kom tilbake til Botn i 1957. Til hans store forbauselse var leiren forvandlet til en kirkegård. Han spurte sine norske venner om hva slags kirkegård det var og fikk til svar: «(...) Det er en tysk kirkegård, her ligger omkring tre tusen tyskere begravd (...)» ${ }^{465}$ På det tidligere leirområdet ble det anlagt en krigskirkegård for tyske graver i Nord-Norge og den jugoslaviske krigskirkegården ble anlagt like ved denne. Løytnant Odd Mjelde deltok i hjelpearbeidet for krigsfangene etter krigen. Han var også med på å plukke ut tyskere som skulle delta i oppgravingsarbeidet av jugoslaviske og sovjetiske ofre. Om den jugoslaviske kirkegården i Botn forteller han at det store antallet jugoslaviske ofre minner oss om alle de lidelsene og uverdige forholdene krigen førte med seg. Mjelde husker at jugoslavene reagerte voldsomt på at den tyske krigskirkegården ble plassert ved siden av deres egen. ${ }^{466}$

Under samlingen av de jugoslaviske gravene i 1953 ble oppgravingen av ofrene i Beisfjord en problematisk oppgave. Merkingen av gravene var svært tilfeldig, og det forelå ingen meldinger fra tyske myndigheter om gravleggingen. Leiren hadde vært svært godt bevoktet, og naboene visste lite eller ingenting om hva som hadde foregått bak piggtråden. Det antatte antallet ofre på 500 døde var basert på naboenes opplysninger til Krigsgravtjenestens distriktskontor i Nordland. Etter at overføringene var gjennomført, ble det funnet beinrester på en av naboeiendommene til fangeleiren. Ifølge lensmannen i Ankenes dreide det seg om levninger etter seks jugoslaviske ofre, og alt ble overført til krigskirkegården i Botn. I alt ble det gravd opp 291 jugoslaviske ofre i Beisfjord, og dødsårsak ble registrert som ukjent. ${ }^{467}$

Gravplassen ved Øvre Jernvatn lå ca. ti kilometer fra Øyjord innpå viddene på Bjørnefjell og ca. to kilometer fra veien. Fangene som ble henrettet

464 RA, Krigsgravtjenesten, eske 26-35. «Konsentrering av jugoslaviske krigsgraver i NordNorge». Storsteinnes. Udatert Oslo desember 1953.

465 Kovačević, Ostoja: En times frihet. Gyldendal, Oslo 1959: 174.

466 Ellefsen, Arild S: «Odd Mjelde intervjues om sabotasje og fangeleirenes åpning i 1945 », i scertrykk Saltdalsboka 1980. Saltdal kommune.

${ }^{467}$ RA, RAFA-2017/Y/Yd/L0179. «Jugoslaviske krigsgraver i Norge». Sentralkontoret for krigsgraver. Oslo, Frognerleiren den 08.02.1955. 
ved Øvre Jernvatn, kom fra Beisfjord fangeleir. Lokalbefolkningen antok at antallet jugoslaviske døde var omkring 200. Tyskerne hadde brukt en grop i fjellet som gravplass, og de døde var plassert lagvis. Ved åpningen av massegraven ble det for det meste funnet små porøse beinrester, som vanskelig kunne settes på rett plass for en identifikasjon av ofrene. Ofrene som var plassert i midten, var bedre bevart og kunne graves opp enkeltvis. Ved oppgravingsarbeidet fikk man mistanke om at tyskerne hadde brukt ulesket kalk for hurtigere å tilintetgjøre de gravlagte, siden rester av kalk ble funnet i jorden på gravplassen. Totalt ble det funnet 35 døde jugoslaviske fanger på gravplassen. Alle ofrene hadde ukjent identitet, og dødsårsak var ukjent, opplyste Sentralkontoret for krigsgraver. ${ }^{468}$

Fremdeles er det graver som ikke er lokalisert ved Øvre Jernvatn, og stedet brukes i dag som minnested for slektninger av jugoslaviske ofre som aldri fikk et anstendig gravsted. Den 22. juni 2011 ble det reist et nytt minnesmerke ved Øvre Jernvatn til minne om den brutale skjebnen fangene møtte på fjellet. Bevaring av sporene etter det tyske leirsystemet og krigsgraver er blitt en stadig større og viktigere del av en internasjonal minnekultur. Øvre Jernvatn leir er sentral i en slik minnekultur, og bevaring er nødvendig for å kunne opprettholde og videreføre minnet om de jugoslaviske krigsfangenes skjebne på norsk jord.

De få gjenværende fysiske sporene etter leirene for de jugoslaviske krigsfangene er svært viktige i formidlingen av fangehistorien i Norge. Den tidligere fangeleiren ved Øvre Jernvatn fra andre verdenskrig ligger omkring to-tre kilometer fra vindmølleparken på Nygårdsfjell. Utbyggingen av Nygårdsfjell vindmøllepark må betraktes som uforenlig med en verdig bevaring av dette minnestedet. Riksantikvaren fremmet i 2007 en innsigelse til planene ut fra hensynet til nyere tids kulturminner av nasjonal verdi. Riksantikvaren beskrev fangeleiren som den best bevarte tilintetgjørelsesleiren i Norge fra andre verdenskrig. Sporene etter leiren var fremdeles noe synlig i terrenget i form av grøfter, stier, piggtråd, maskingeværstillinger og tufter etter brakker. Riksantikvaren var av den oppfatningen at de eksisterende tre turbinene allerede var et forstyrrende element for opplevelsen og formidlingen av denne spesielle og tragiske delen av norsk historie. Riksantikvaren påpekte i innsigelsen at en utvidelse med opptil elleve nye turbiner ville dominere synsinntrykket slik at det ville være uforenlig med at dette skulle være et sted for verdig ettertanke.

Riksantikvarens innsigelse fikk ingen effekt på planene til Nordkraft Vind, og arbeidet med en utvidelse av vindmølleparken med elleve nye turbiner stod ferdig i oktober 2011.

468 RA, RAFA-2017/Y/Yd/L0179. «Jugoslaviske krigsgraver i Norge». Sentralkontoret for krigsgraver. Oslo, Frognerleiren den 08.02.1955. 


\subsection{Polske krigsgraver}

I løpet av årene1942 til 1944 ble flere tusen polske krigsfanger, tvangsarbeidere og soldater i tysk tjeneste sendt til Norge. Om lag 1700 polske krigsfanger ankom i løpet av tre år. Fangene var tidligere soldater fra det tyske felttoget i Polen høsten 1939 og ble sendt hit til landet som tysk arbeidskraft. ${ }^{469}$ De polske krigsfangene ble skilt fra andre nasjonaliteter og delt inn i egne bygge- og arbeidsbataljoner. Ved årsskiftet 1942/43 ble 820 polske krigsfanger sendt fra en fangeleir ved Hamburg i Tyskland til Kristiansand. Under krigen var det også polske soldater i tysk krigstjeneste som flyktet fra Norge. Vanligvis flyktet de til Sverige, og mange nordmenn hjalp dem å komme over grensen. Det var også mange polske tvangsarbeidere i Organisation Todt i Norge. Egne rekrutteringsbyråer for Organisation Todt sørget for mange nye polske arbeidere til organisasjonen. Disse arbeidet i hovedsak ved Nordlandsbanen eller med befestningsarbeid. En annen grunn til å bli med i organisasjonen frivillig som arbeidskraft var å unngå arrestasjon for å ha vært aktive i den polske hjemmefronten, Armia Krajowa (AK). Mange av disse frivillige arbeiderne i Organisation Todt hadde planer om å flykte fra Norge eller Finland til Sverige og senere komme seg til England for å slutte seg til polske hæren i landet. De polske arbeiderne tok del i flere byggeprosjekter. Noen av disse prosjektene var byggingen av jernbanen i Nord-Norge, veianlegg, bygging av gjerder, brakker, brygger og tunneler. Ved slutten av krigen ble det registrert om lag 7000 polske arbeidere i over 20 leirer i Norge. En stor andel av polakkene ønsket ikke å returnere tilbake til Polen etter krigen, og om lag 1000 polske statsborgere slo seg ned i Norge. ${ }^{470}$

164 polske krigsfanger døde på norsk jord og ble gravlagt på egne kirkegårder på Oslo Vestre gravlund, Moholt kirkegård i Trondheim og på Narvik nye kirkegård og Håkvik kirkegård. Størsteparten av dem som er gravlagt på Håkvik kirkegård, var polske soldater som falt i kampene ved Narvik i 1940. Samlingen av gravene ble gjennomført i samråd med den polske legasjonen i Oslo.

Polske krigsgraver ble også flyttet flere ganger etter krigens slutt. På Helland kirkegård i Sørfold står det et minnesmerke over åtte polske fanger som ble skutt etter å ha rømt fra fangeleiren på Torkilseng. De rømte fangene ble senere tatt av tyskerne ved Lappelva og skutt. Etter først å ha blitt gravlagt på retterstedet ble de senere flyttet til Helland. En av de drepte krigsfangene var bare 15 år gammel da han ble henrettet. Faren til den drepte gutten befant seg

469 Stokke, Michael: Sovjetiske og franske sivile tvangsarbeidere i Norge 1942-1945. Masteroppgave i historie. Universitetet i Bergen. 2008: 5.

470 Denkiewicz-Szczepaniak, Emilia: «Polske OT-tvangsarbeidere og krigsfanger i Norge under annen verdenskrig», i Historisk tidsskrift 1997, 2: 281. 
$\mathrm{i}$ «utlendingenes leir» $\mathrm{i}$ Bodø i august 1945. Hans $ø$ nske var at sønnen og de andre ofrene skulle bli gravd opp fra gravstedet i Megården og flyttet til kirkegården i Mo i Rana. ${ }^{471}$ Gravene ble imidlertid ikke flyttet dit. Minnesmerket på Helland ble reist i 1953, da de gravlagte ble flyttet til sitt endelige hvilested på Håkvik kirkegård i Narvik. I tillegg til navnene på de åtte polakkene som ble skutt, står følgende tekst på minnesmerket på Helland kirkegård: «Her ligger gravlagt de polakker som ble myrdet av de hitlerske banditter den 31.05.1944.»

Minnesmerkene over de polske krigsgravene ble gjenstand for debatt i norsk presse. Det polske krigsdeltagerforbundet i Norge og Storbritannia protesterte mot at det nye polske riksvåpenet (ørnen uten krone) skulle pryde utsmykkingen av minnesmerkene. Utenriksminister Halvard Lange overlot avgjørelsen av saken til Stortinget. Her var det enighet om at minnesmerket ikke kunne inneholde det kommunistiske symbolet, og de fremhevet at den norske opinionen mente det var upassende at minnesmerket over de polakkene som falt i Norge, skulle smykkes med det nye regimets riksvåpen. Regjeringen var imidlertid ikke enig. Deres oppfatning var at de ferdige minnesmerkene burde settes opp så snart gravplassene var satt i stand. De mente at det ikke var noen grunn til å gjøre noen unntagelser for de polske gravene fordi det hadde vært et systemskifte etter krigen. I 1956 kunne Aftenposten melde at den sørgelige striden om de polske minnesmerkene over de falne polakkene i Norge hadde fått en lykkelig løsning. Stortinget hadde godkjent representant for Høyre, Ole Bergesens, forslag om å sette opp nøytrale minnesmerker på gravene. ${ }^{472}$ Diskusjonene hadde til tider vært anspent da saken ble tatt opp. En av representantene fremhevet at det var viktig å respektere de døde, men at følelsene var kommet i strid med de formelle kravene i denne saken. Han avviste også ideen om et kristent kors fordi en del av de gravlagte var jødiske. En annen representant viste til at mange polske flyktninger hadde reist hjem og benyttet anledningen til å anmode de gjenværende om også å reise tilbake.

\footnotetext{
471 RA, DKN, 316 krigsgraver i Nord-Norge. Notat vedrørendeTomasz Staniak, Distriktskommando Nord-Norge. Bodø 03.08.1945.

472 Aftenposten, 05.06.1956.
} 


\section{Minnet om de døde}

I sammenheng med identifikasjonsarbeidet av de sovjetiske ofrene har også de ulike minnestedene og krigskirkegårdene fått økt oppmerksomhet. Krigsgraver og krigsminnesmerker utgjør en viktig del av krigens kulturminnelandskap. Ofre av ulike nasjonaliteter er gravlagt i Norge, men gravene med østeuropeiske ofre har ikke vært en del av den norske kollektive erindringen.

I dag er det ingen gravkors igjen på den store sovjetiske krigskirkegården som lå på Hestbrinken i Saltdal. Det eneste som vitner om at dette var en krigskirkegård på 1950-tallet, er et grått lite minnesmerke som offisielle myndigheter hadde satt opp etter at gravene ble flyttet. Flere hundre hvite kors med navnene på ofrene som var identifisert i 1945, ble fjernet under flyttingen av gravene. En stor minneplate med navn på 40 sovjetiske ofre som døde i Saltdal, ble oppbevart av en av dem som deltok i flyttingen av krigskirkegården fra Hestbrinken til Tjøtta. Minneplaten ble funnet ved en tilfeldighet bare noen få dager før Saltdal kommune fikk besøk av sovjetiske gjester for første gang etter krigen ved markeringen av 40-årsdagen for freden 8. mai 1985. ${ }^{473}$ Arild Steen Ellefsen fra Saltdal kommune ønsket å drøfte med Krigsgravtjenesten hvor minneplaten eventuelt skulle settes opp, men det er ingenting som tyder på at dette ble gjort. Hestbrinken krigskirkegård er et glemt og gjengrodd minnested. Det er ingen skilting ved stedet, og naturen har fått ta over området rundt minnesmerket.

473 Ellefsen, Arild S.: «Russefanger, repatrieringen og Hestbrinken krigskirkegård», i scertrykk Saltdalsboka, Rognan 1986: 120-121. 


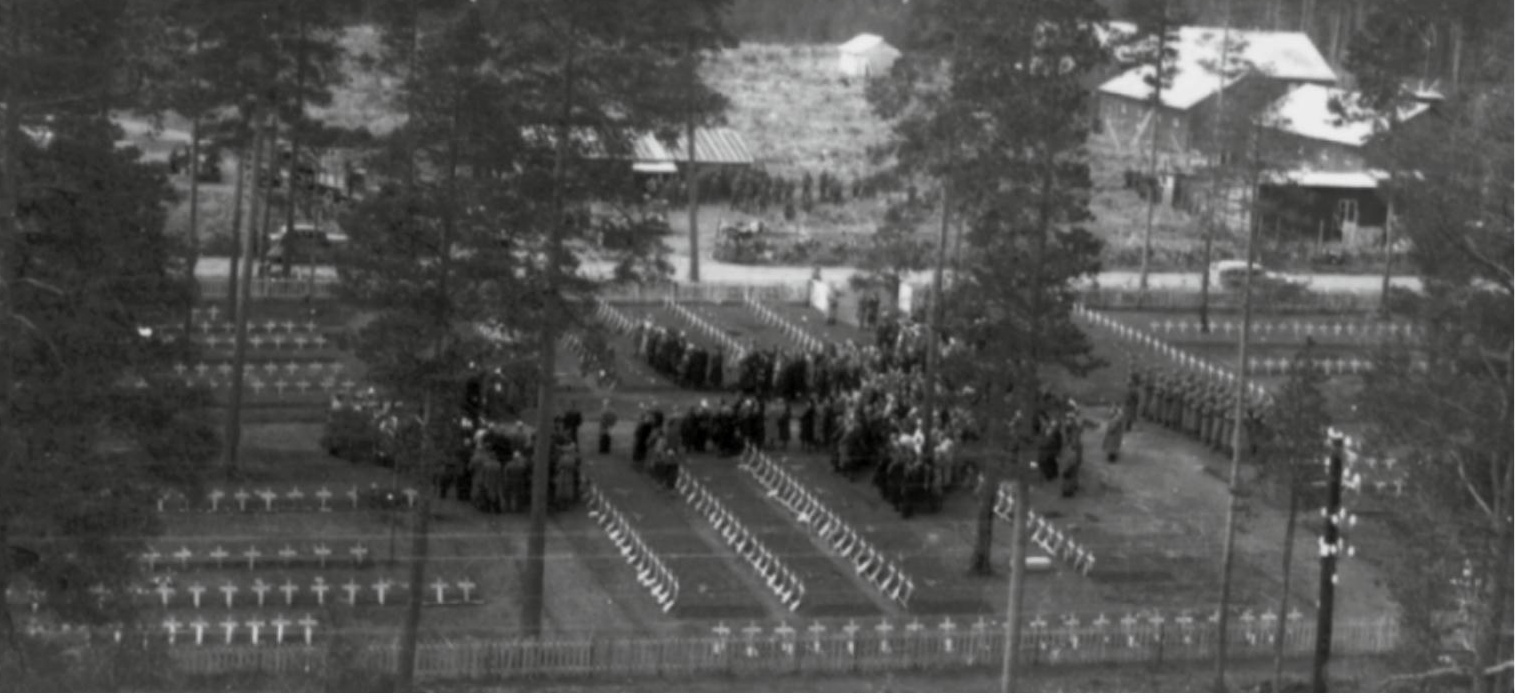

Hestbrinken krigskirkegård i Saltdal 1945. Foto: Salten Museum.

I dag vitner kun et gjengrodd felles minnesmerke om de sovjetiske krigsfangenes skjebne i fjellet ved Kobbvatn. Minnestedet er knapt tilgjengelig, og adkomsten er ikke merket. På disse stedene er de sovjetiske enkeltgravene blitt borte og det gis heller ingen mulighet til å vedlikeholde et aktivt minne om de sovjetiske ofrene. Fraværet av informasjonsskilt om Hestbrinken og Kobbvatn gjør dette til anonyme steder som ikke lenger tilhører erindringen om krigen i Norge.

En del graver og minnesmerker i Nordland er plassert ved tidligere krigsfangeleirer. På det tidligere leirområdet i Botn i Saltdal finnes det både en kirkegård for tyske soldater og en for jugoslaviske ofre. Utenfor muren ved den jugoslaviske kirkegården er det også satt opp en minnestein over de sovjetiske krigsfangene som mistet livet i Botn.

De sovjetiske krigsfangene som tema endret karakter da de ble trukket inn i den kalde krigen. Oppmerksomheten om fangenes skjebne etter repatrieringen passer inn i det samme mønsteret. Erindringen dreide seg fra å være et tema for okkupasjonshistorien til å bli et tema fra den kalde krigen. Krigsfangene var ikke lenger gjenstand for oppmerksomhet som ofre for nazismen, men ofre for stalinismen. I de første etterkrigsårene var erindringen knyttet til krigsfangenes 
skjebne på norsk jord, men senere ble erindringen kun konsentrert om fangenes skjebne etter hjemkomsten. Flyttingen av gravene var også med på å forsterke inntrykket av at krigsfangenes historie tilhørte den kalde krigen. Egil Ulateig skriver i boken Hjem til Stalin (1985) at svært mange frigitte sovjetiske krigsfanger ble sendt i døden eller til Sibir. ${ }^{474}$ Denne oppfatningen resulterte $\mathrm{i}$ at erindringen om fangenes skjebne var nær knyttet til den kalde krigen. Hjemvendte sovjetiske krigsfanger og deres skjebne har i lang tid vært gjenstand for ulike spekulasjoner. Som regel har sovjetiske myndigheters mottakelse av krigsfangene blitt ensidig fremstilt av vestlige forfattere, som konsentrerte seg om at de repatrierte ble henrettet eller sendt til mange år i straffarbeidsleirer. Tidligere krigsfangers beretninger viser at de som regel ble utsatt for en grundig undersøkelse etter hjemkomsten, men på langt nær så mange som tidligere antatt ble henrettet eller sendt til sovjetiske arbeidsleirer. Senere tids forskning fra sovjetisk side har gitt et noe annet bilde, som tilsier at over halvparten ble sendt direkte hjem, noe som i høy grad bidrar til en nyansering av tidligere fremstillinger. ${ }^{475}$

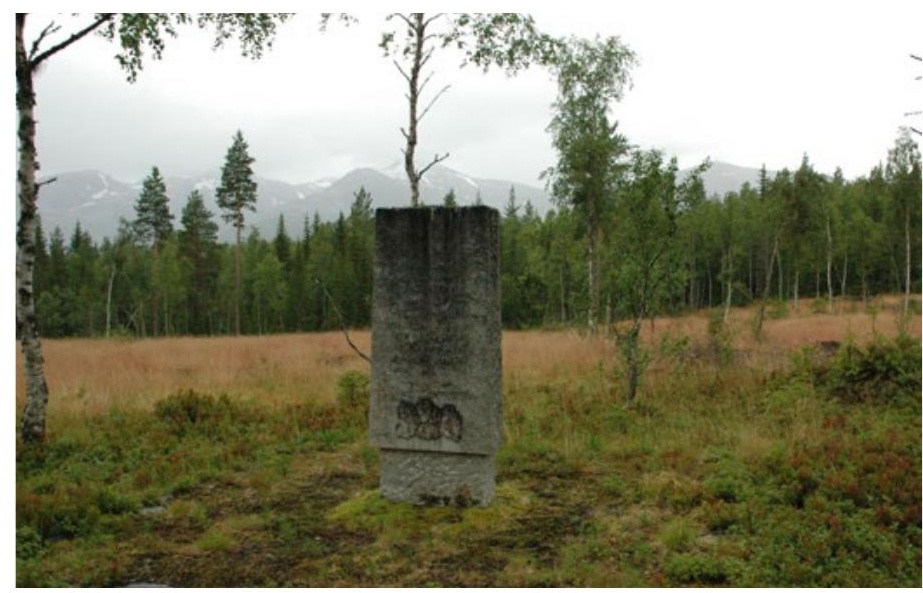

Minnesmerket ved Kobbvatn 2009. Foto: Marianne Neerland Soleim.

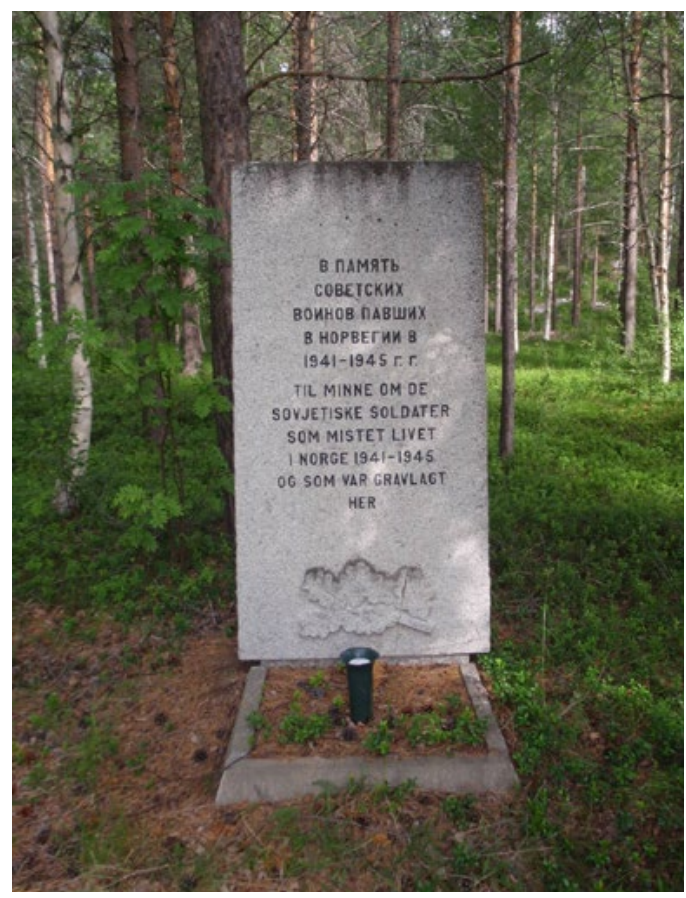

Hestbrinken krigskirkegård 2012. Foto: Per-Otto Gullaksen.

${ }^{474}$ Ulateig, Egil: Hjem til Stalin. Skjebnen til 83000 russiske krigsfanger i Norge 1945. Cappelen, Oslo 1985: 155.

475 Soleim, Marianne Neerland: Sovjetiske krigsfanger i Norge - Antall, organisering og repatriering. Avhandling i historie, Universitetet i Tromsø 2004: 403-404. 
I en studie om den rituelle bruken av norske krigsminnesmerker skriver Kyrre Kverndokk at ved å gjennomføre bekransningsritualer med høyverdig symbolbruk blir den kollektive erindringen om andre verdenskrig aktualisert, og de personene eller gruppene som minnes via seremoniene, får stadfestet sin posisjon innenfor denne erindringen. Videre skriver han at ved å ta i bruk tunge nasjonale symboler blir seremonien og dens innhold knyttet til det nasjonale fellesskapet. ${ }^{476}$ Folklorist Anne Eriksen har påpekt at kunnskapen, erfaringene og minnene fra krigen kan samlet betraktes som en form for kollektiv erindring eller en kollektivtradisjon. ${ }^{477}$ Hun viser også til at en gjennomgang av andre verdenskrig i norsk kollektivtradisjon har vist at fortellingen om krigen gir et rom der nasjonale verdier og egenskaper kan utfoldes. Fortellingen formidler verdier og oppfatninger som ofte betraktes som «typisk norske», og den har skapt en nasjonal konsensus, mener hun.

Hovedoppgaven til Bjørn Knutsen er et arbeid med vekt på teoretiske perspektiver: Erindringen omkring de østeuropeiske krigsfangene i Norge En drofting av realhistorie versus erindringshistorie med vekt på historisk bevissthet og kollektiv erindring. ${ }^{478}$

Hovedproblemstillingen til Knutsen er knyttet til spørsmålet om hvordan erindringen omkring de østeuropeiske krigsfangene i Norge har utviklet seg i etterkrigstiden. Med utgangspunkt i teori om historisk bevissthet, erindring og «erindringspolitikk» har Knutsen skrevet en komparativ analyse av erindringshistorie versus realhistorie, hvor omdreiningspunktene er historisk bevissthet og kollektiv erindring. Knutsen avklarer forskjellen på disse to begrepene: Med historisk bevissthet menes en tenkemåte der en kontinuerlig gransker ens egen historieforståelse og oppfatning av historien slik den har forløpt, og er villig til å revidere den dersom en møter ny kunnskap som tilsier dette. Erindring, og da særlig kollektiv erindring, kan derimot være styrt av mekanismer og behov som har andre formål enn adekvat representasjon av fortiden. Her berører de to viktige begrepene realhistorie og erindringshistorie hverandre. Realhistorie er den fortidige virkeligheten og erindringshistorie er slik en person eller en gruppe minnes den samme fortiden. Kollektiv erindring kan forstås som et uttrykk for en sosial gruppes erindring og erindringshistorie som fremstillingen

${ }^{476}$ Kverndokk, Kyrre: De kjempet, de falt, de gav oss alt - om den rituelle bruken av norske krigsminnesmerker. Hovedoppgave i folkloristikk Institutt for kulturstudier. Oslo 2000: 74.

477 Eriksen, Anne: Det var noe annet under krigen. Pax Forlag, Oslo 1995: 14.

478 Knutsen, Bjørn: Erindringen omkring de østeuropeiske krigsfangene $i$ Norge - En drøfting av realhistorie versus erindringshistorie med vekt på historisk bevissthet og kollektiv erindring. Hovedoppgave i historie, Bergen 2001. 
av personers og gruppers erindring. Ifølge Knutsen har kunnskap om de østeuropeiske krigsfangene blitt inkorporert i nordmenns bevissthet i sterk nok grad til at den nå uttrykkes gjennom den kollektive erindringen. ${ }^{479}$

Sentrale erindringssteder/arenaer viser utviklingstrekk ved den historiske bevisstheten om de sovjetiske krigsfangene over tid. Slike steder eller arenaer er aviser, forskning (primær og sekundær), litteraturutgivelser (forsknings- og populærlitteratur), museer, krigsmonumenter, skolen (læreplaner og pensumbøker), samt andre arenaer (lokalhistorie og filmer). I en analyse av aviser som erindringsarena foretar Bjørn Knutsen følgende inndeling av nordmenn som opplevde krigen: De som ikke visste; de som ikke ble informert på grunn av bosted og kommunikasjon. De ufrivillige vitnene, de som stilltiende og passivt observerte krigsfangene og deres skjebne. De aktive vitnene, de som hadde kunnskap om krigsfangene og som engasjerte seg for å hjelpe dem. De som tilhørte denne gruppen har i ettertid publisert størsteparten av den lokalhistoriske litteraturen om krigsfangene. De økonomiske kollaboratørene var forretningsfolk og arbeidstakere som samarbeidet med okkupasjonsmakten økonomisk. Imidlertid er koblingen til krigsfangene her vanskelig på grunn av tausheten fra aktørene og manglende bekreftelse på at norske firmaer benyttet seg av sovjetiske krigsfangers arbeidskraft. De ideologiske og politiske kollaboratørene var NS-medlemmer, norske fangevoktere i leirene og frontkjemperne. ${ }^{480}$ Analysen viser ulike erindringstrekk ved noen utvalgte avisers formidling om krigsfangene. Avisen Fædrelandsvennen skrev mye om de utenlandske krigsfangene i frigjøringstiden. Likevel hadde omtalen begrensninger. Oppmerksomheten ble rettet mot fanger andre steder i landet, eller bare med hensyn til selve feiringen av frigjøringsjubileet lokalt. Fangeleirene og slavearbeidet i Agder ble ikke viet noe plass i avisen. Tabuisering og følelsesmessige belastninger ved utstrakt norsk økonomisk kollaborasjon i lokalmiljøet antas å være en viktig årsak til at de østeuropeiske krigsfangene i dette området heller ikke fikk noen større oppmerksomhet. Formidlingen i Aftenposten ble karakterisert ved samme kjennetegn som for gruppen ufrivillige vitner. Forholdet til fangene var ikke av personlig karakter, de tidligere krigsfangene var ikke noe en kunne identifisere seg med eller forholde seg til, og derfor ble de snart glemt. Nordlands Fremtid hadde en massiv omtale av fangene, og ble derfor karakterisert på linje med gruppen aktive vitner. Krigsfangene ble husket som individer.

479 Ibid.: 108.

${ }^{480}$ Knutsen, Bjørn: Erindringen omkring de østeuropeiske krigsfangene $i$ Norge - En drøfting av realhistorie versus erindringshistorie med vekt på historisk bevissthet og kollektiv erindring. Hovedoppgave i historie, Bergen 2001. 
Såkalte standard minnestøtter over sovjetiske krigsfanger ble plassert over hele landet. Oversikten over de sovjetiske minnesmerkene fra Krigsgravtjenesten viser at minnesmerkene som er reist av norske myndigheter, har ulik tekst. På minnesmerker i Nord-Norge og Charlottenlund i Trondheim er betegnelsen «soldater» brukt, og i resten av landet er betegnelsen «borgere» oppført på minnesmerkene. På minnesmerket ved det sovjetiske fellesgravstedet på Tjøtta er betegnelsen «soldater» brukt. Følgende inskripsjon er oppført på sovjetisk og norsk, hvor den sovjetiske står øverst: «I takknemlig minne om sovjetiske soldater som mistet livet i Nord-Norge under krigen 1941-1945 og som er gravlagt her». Det var i 1955 at Utenriksdepartementet endret forslaget til inskripsjon på monumentene i SørNorge og betegnelsen «soldater» ble byttet ut med «borgere». ${ }^{481}$ Årsaken til hvorfor betegnelsen ble endret, er ikke oppgitt. En mulig forklaring er at det befant seg sivile fanger blant de døde, og at man derfor endret betegnelsen. Men dette ble ikke endret på alle monumentene som var reist av lokale myndigheter i Sør-Norge. På de lokale monumentene er det brukt betegnelsene «soldater» eller «krigsfange». Hverken norske eller sovjetiske myndigheter ønsket å minnes de døde som krigsfanger på de offisielle monumentene som ble satt opp både i Sør-Norge og Nord-Norge.

I Norge var det viktig for de overlevende fangene å minnes dem som døde. Som vi har sett tidligere, var det ikke lett å bevare minnesmerkene som var laget av gjenlevende sovjetiske krigsfanger, og flere steder i Norge ble det lagt opp til en standardisering av minnesmerkene etter at «Operasjon asfalt» var gjennomført. Hva gjorde dette med minnet om de falne, og er de største krigskirkegårdene for sovjetiske ofre glemte steder i dag?

481 RA, Krigsgravtjenesten, eske 26-35. Notat, Utenriksdepartementet. Oslo 05.05.1955. 


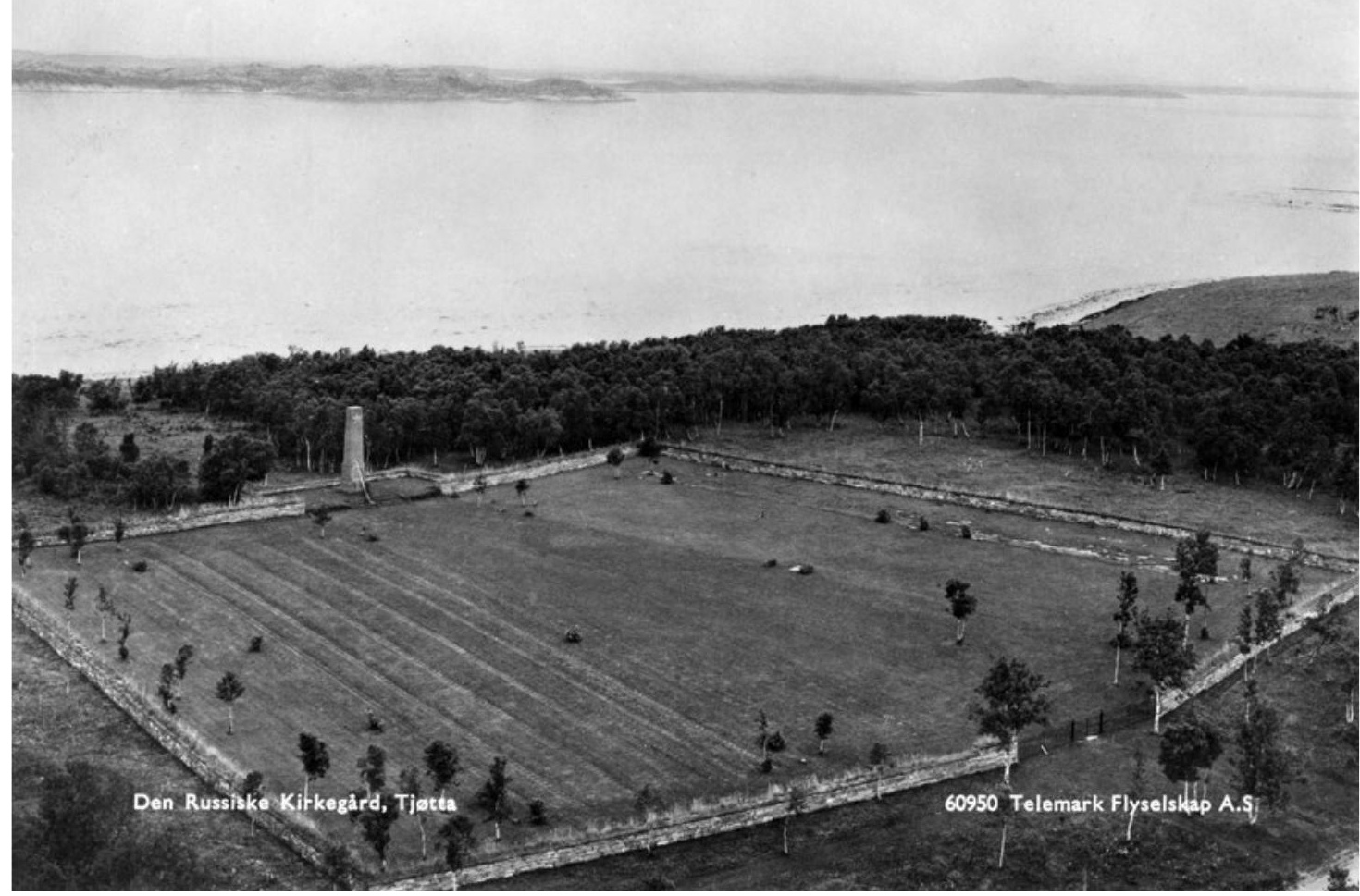

Tjøtta krigskirkegård, ca. 1953. Foto: Johan Ottesen historisk fotoarkiv og forlag.

\subsection{Tjøtta krigskirkegård}

Innvielsen av den sovjetiske krigskirkegården på Tjøtta fant sted den 8. juli 1953. Flere hundre mennesker fra hele distriktet overvar åpningsseremonien hvor utenriksminister Halvard Lange og Sovjetunionens ambassadør i Norge, F.A. Afanasiev, holdt avdukningstaler. I sin tale understreket Lange regjeringens ønske om godt naboskap med Sovjetunionen. Han fremstilte det som om regjeringen kun hadde hatt edle motiver for flyttingen av gravene. Det ble hevdet at hensynet til de døde ble satt i første rekke. Ifølge Lange ble gravene flyttet til Tjøtta fordi mulighetene for forsvarlig vedlikehold var bedre. Afanasiev ga uttrykk for tilfredshet med gravplassen. I forbindelse med åpningen av krigskirkegården stod det i Helgelands Blad at etter norsk oppfatning var Tjøtta et vakkert anlegg og et verdig gravmæle over våre russiske venner som mistet livet i vår felles kamp om frihet og rett. ${ }^{482}$ Nordlands Avis hadde etter innvielsen en artikkel hvor anlegget ble beskrevet som et enkelt og stilfullt minnesmerke over 8000 soldater. I artikkelen ble det påpekt at mye strid hadde stått om soldatkirkegården på Tjøtta. Det hadde tatt sin tid å få hele anlegget ferdig. I snart to år hadde arbeidet med krigskirkegården pågått. Før lå ofrene spredt på gravsteder over hele landsdelen, men nå var

482 Helgelands Blad, udatert 1953. 
det mulig å gi dem et felles minnested med varig verdi. Et ønske i artikkelen var formulert som: «Vi tror det norske folk ... og i første rekke befolkningen på Helgeland i framtiden vil påse at den vakre soldatkirkegården på Tjøtta blir vernet om.» ${ }^{483}$

Planleggingen av en krigskirkegård på Tjøtta for omkomne fra «Rigel» startet i 1969. I hovedsak var det ikke mulig å identifisere de omkomne. Anlegget ble derfor lagt opp som en fellesgrav hvor samtlige omkomne eller rester etter omkomne funnet i og omkring vraket ble gravlagt. Grunntanken bak fellesgravens utforming var at den skulle virke som en gammel skipsgrav, og minneplaten ble derfor ikke plassert på gravområdet, men ved inngangen. ${ }^{484}$ Et tre meter høyt monument i lys granitt formet som et kors ble plassert midt på gravfeltet. Anlegget er en internasjonal krigskirkegård og er plassert ved siden av den sovjetiske krigskirkegården på Tjøtta. Den ble kirkelig vigslet 6. september 1970.

I desember 1977 samlet representanter fra den sovjetiske ambassaden, regjeringen og Forsvaret seg på Tjøtta da monumentet over «Rigel»-ofrene ble avduket. Samme dag ble fem sovjetiske krigsofre som var blitt funnet i en fellesgrav ved Kirkenes, gravlagt på krigskirkegården på Tjøtta. Ved

484 KUD, 6656 KiAK. «Anlegg av krigskirkegård for omkomne fra fangeskipet «Rigel» senket ved Rosøy 1944». 
50-årsmarkeringen av «Rigel»-katastrofen var to overlevende, Asbjørn Schultz og Julian Oreschin, til stede. Mange av dem som hjalp til og var øyenvitner til tragedien ute ved Rosøya høsten 1944, deltok også i minnemarkeringen. Varaordfører Kolbjørn Nesjan i Alstahaug kommune la i sin tale vekt på det meningsløse ved denne katastrofen, der mer enn 2500 mennesker mistet livet, og det trolig på grunn av en feiltakelse. Han roste Tjøttas befolkning som hadde hjulpet de overlevende uten hensyn til nasjonalitet.

Ved frigjøringsjubileet i 1995 var en av de få overlevende etter «Rigel»-katastrofen, Boris Nagovitsin, tilbake på Tjøtta. Det ble et sterkt møte for både ham og dem som så på da Nagovitsin hedret minnet over de døde. Han innledet sin lille seremoni med å spre brød i gresset rundt monumentet over «Rigel»-ofrene før han falt på kne og takket dem som ga sitt liv og de norske familiene som hjalp til med å redde overlevende etter katastrofen.

«I takknemlig minne om sovjetrussiske soldater som mistet livet i NordNorge under krigen 1941-1945 og som er gravlagt her», står det på den syv meter høye bautaen over den store fellesgraven på Tjøtta krigskirkegård. Bautaen fremstår som et symbol på den ukjente soldats grav, men krigskirkegården har flere minnesmerker. Gravene er delt i to felter, et for dem som har kjent identitet og et for de ukjente. De identifiserte ofrene er minnet med egne navneplater med norsk og russisk inskripsjon. Synliggjøring av krigsofrenes navn på krigskirkegårdene er viktig for dem som i mange tiår har lett etter svar på hvilken skjebne som møtte slektningene deres i Norge. Navnene forteller oss om sovjetiske soldater som fant sin død i fremmed jord, langt fra hjem og familie. Navneplatene er svært viktige for slektninger og etterkommere av ofrene, som leter etter navnet til en far eller bestefar som endte sitt liv i tysk fangenskap i Norge.

Sommeren 2002 ble navneplatene på de identifiserte gravene fjernet fra krigskirkegården i regi av Krigsgravtjenesten. Denne anonymiseringen av ofrene var et tilbakeslag for bevaringen av minnestedet og respekten for ofrene. Navneplatene er en viktig del av minnestedet Tjøtta. De formidler ikke bare en glemt historie på norsk jord, men gir også et unikt nærvær til historien i form av noe så enkelt som et navn, en identitet. Argumentene for fjerningen var at navneplatene sank ned i bakken og skadet gressklipperen 
under arbeid med vedlikehold av minnestedet. Alstahaug kommune og Norske reserveoffiserers forening i Alstahaug reagerte kraftig på at navneplatene ble stuet vekk på en låve i nærheten. Fra sistnevnte forening står det stor respekt av Inge Bildøys utrettelige innsats og engasjement for saken om å få satt på plass navneplatene. Nordland Fylkeskommune engasjerte seg også sterkt i saken og anmodet i slutten av 2005 om at navneplatene til de døde med kjent identitet ble satt på plass igjen. Først tre år senere var navneplatene tilbake på krigskirkegården. Krigsgravtjenesten på sin side forsikret fylkeskommunen at når det gjaldt de sovjetiske krigsgravene i Norge, var forholdet mellom norske og sovjetiske myndigheter upåklagelige. I tillegg informerte Krigsgravtjenesten om arbeidet vedrørende samling av krigsgravene, registrering av falne sovjetiske fanger, monumenter over sovjetiske falne og fullføringen av navnelistene for sovjetiske falne.

I juni 2012 sendte Krigsgravtjenesten ved Fornyings-, Administrasjonsog Kirkedepartementet ut en høring angående merking av navn på Tjøtta sovjetiske krigskirkegård. Høringen omfattet utformingen av nye minneplater, merking av gravfelt A og informasjonsplater. Krigskirkegården er inndelt i to gravfelt, A og B. På felt A, der de 826 navngitte er gravlagt, er det også gravlagt 207 ukjente og 173 som er identifisert bare med fangenummer. Totalt er det om lag 1200 graver på felt $\mathrm{A}$, som alle er registrert med gravrekke og nummer. På felt B er det gravlagt om lag 6800 sovjetiske ofre. Av disse har fangenummer på 600 vært kjent, men ikke hvor på felt B disse er gravlagt. Dette innebærer at selv om man klarer å identifisere navnene på de fleste ofrene som er gravlagt på Tjøtta, vil det ikke være mulig å identifisere den enkelte graven på felt $\mathrm{B}$ og heller ikke knytte navn til de ukjente gravene på felt $\mathrm{A}$.

\subsection{Falstadskogen}

Av de 360 sovjetiske krigsfangene som var sendt til Falstad i årene 19411945, ble antakelig rundt 100 henrettet. En stor andel av fangene var tatt under flukt fra andre leirer i distriktet. Denne fangegruppen hadde størst sjanse for å overleve om de ble sendt til leiren i årene 1944 eller 1945. Det var om lag 150 polske krigsfanger som ble sendt til Falstad. En stor andel ble sendt fra leirer i Nord-Norge og videre til Oslo blant annet på grunn av ulovlig kontakt med nordmenn. Etter opphold på Falstad ble utenlandske krigsfanger også sendt videre til ulike leirer i Trondheims-distriktet for å utnyttes som arbeidskraft. Det er usikkert om det var tilfeller av polske henrettede i Falstadskogen som ble identifisert som sovjetiske fanger etter krigen. 


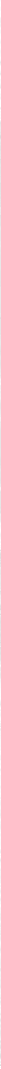

Sovjetiske krigsfanger, Falstad fangeleir 1945. Arkiv: Falstadsenteret.

Krigsgravplassen Falstadskogen ble formelt etablert i juni 1947 og står i dag som et nasjonalt symbol over krigens ofre. Tidligere fange på Falstad, Odd Hilt, har laget hovedmonumentet, og om symbolikken uttalte han at de «tyske soldatene med skuddklare gevær er laget uten ansikter. De representerer den uniformerte krigsmaskinen som bare lystrer ordre. Mot dem står kjempende mennesker. Fremst står en uredd mann. Det kan godt være en jugoslav eller en russer. Menn som uredd tok opp kampen.» ${ }^{485}$ Hilt fremhevet at det var mange som ønsket et mer liberalt motiv i monumentet, men han mente at det var mer riktig å fremstille den tids virkelighet slik den var. Avdukingen av monumentet ble forestått av kronprins Olav i 1947, i sin tale uttrykte han at Falstad skulle bli et valfartssted for frihetstankens pilegrimer fram gjennom tidene. Svært mange var til stede under avdukingen, blant annet en del av de norske ofrenes etterlatte og representanter fra den jugoslaviske og den sovjetiske ambassaden. Opprettelsen av monumenter er en offentlig og kollektiv prosess hvor de lidende individene får allmenn anerkjennelse. Men denne offentlige hukommelsen gir ikke bare fordeler. I USA har historiker John Bodnar analysert nasjonale minnesmerker, og han poengterer at det er en dikotomi mellom intensjonene og interessene til gruppene som initierer

485 Arbeider-Avisa, 29.10.1984. 
monumentene og den store massen av brukere. Den første gruppen ønsker å synliggjøre fortiden slik at den kan danne et ideelt mønster for samfunnet i fremtiden, mens for den store gruppen av brukere er monumentet et direkte uttrykk for erfaringer og konkrete handlinger. ${ }^{486}$

Et annet monument i Falstadskogen ble laget av kunstneren Gunnar Janson og avduket i 1963. Det er reist til minne om de ulike nasjonalitetene som ble henrettet i Falstadskogen i krigsårene, og kan sees som et uttrykk for sammenbrakte erindringer.

Holocaustekspert, professor James Young, viser til begrepet «collected memory» (sammenbrakte erindringer) som et alternativ til begrepet kollektive erindringer. Collected memory blir her definert som mange atskilte erindringer samlet $\mathrm{i}$ et felles erindringsrom og tillagt felles mening. Med dette etableres det et skille mellom felles erindring og felles mening. ${ }^{487}$ At folk er samlet om å erindre på de samme stedene har betydning, men dette medfører ikke automatisk at folk er samlet om erindringens innhold. Men, ved å skape

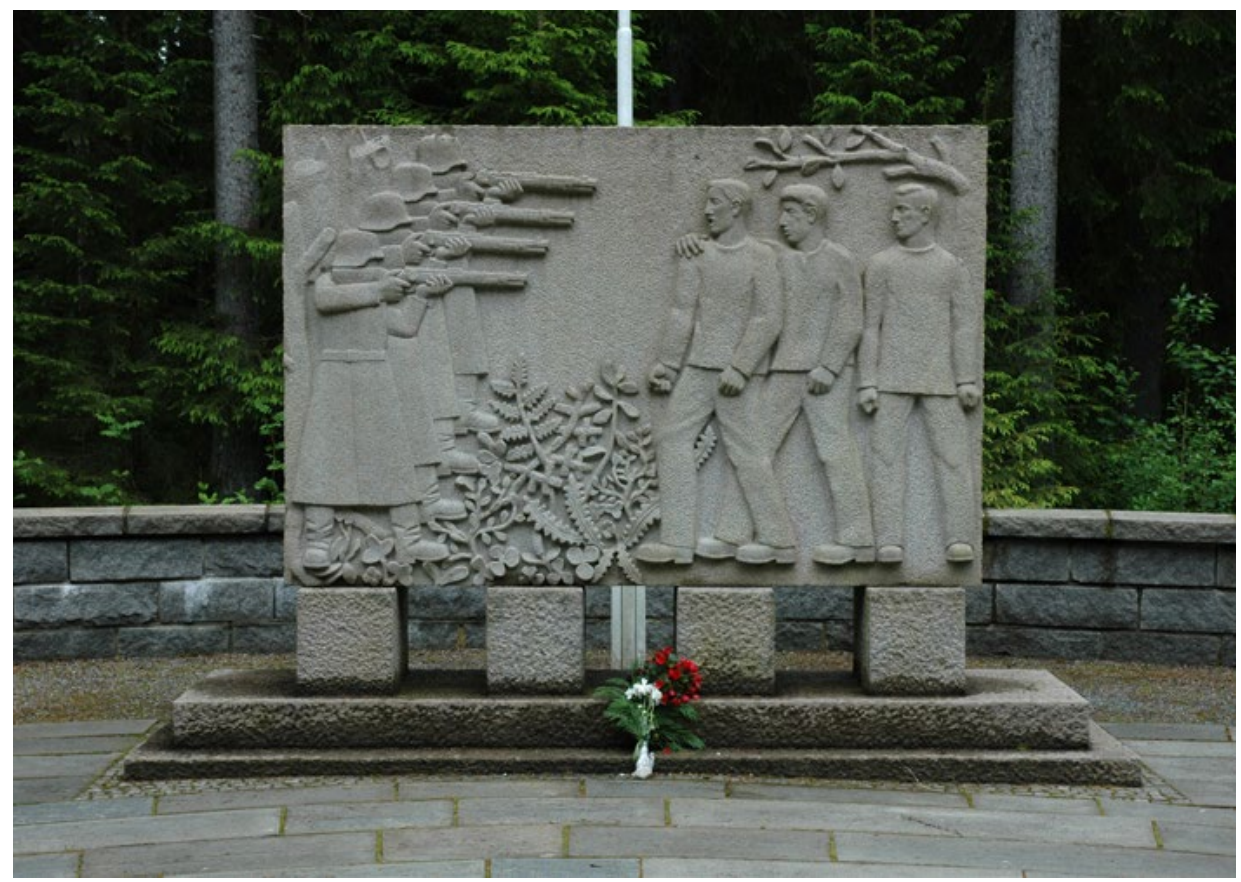

Monument i Falstadskogen 2011 laget av tidligere fange Odd Hilt.

Foto: Arne Langås, Falstadsenteret.

486 Bodnar, John: Remaking America: Public Memory, Commemoration, and Patriotism in the Twentieth Century. Princeton University Press, New Jersey 1992.

487 Young, James E: The Texture of Memory. Yale University Press, New Haven/London 1993: xi. 
et felles rom for erindring gir erindringsstedene en illusjon om en felles eller kollektiv erindring. ${ }^{488}$ Dette begrepet viser hvordan minne og erindring knyttet til flere nasjonaliteter kan knyttes til samme monument. Monumentet i Falstadskogen gir en mulighet for de besøkende å minnes ikke bare lidelsene til nordmenn, men også jugoslavene og russerne som ble henrettet i skogen. På monumentet kan vi lese at 205 mistet livet $i$ Falstadskogen, men senere forskning har avdekket at tallmaterialet ikke

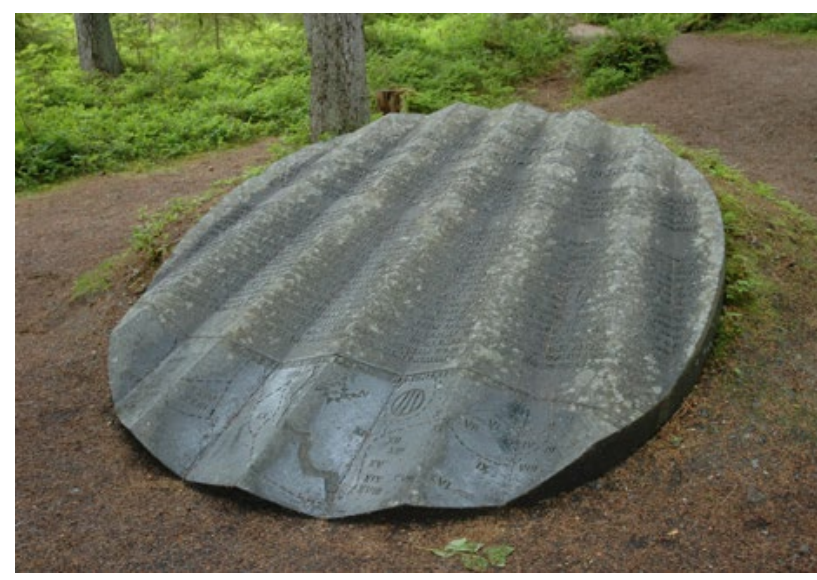

Gunnar Jansons monument i Falstadskogen 2011. Foto: Arne Langås, Falstadsenteret. er korrekt. Blant annet er antallet jugoslaviske og sovjetiske ofre for lavt, og det er usikkert om det var tilfeller av polske henrettede som ble identifisert som sovjetiske fanger etter krigen. Kildematerialet har åpenbart ikke vært korrekt, og en jugoslavisk fange som klarte å rømme kvelden før han skulle henrettes, er feilaktig blitt oppført blant navnene på falne. Monumentet består av en stor steinplate som ligger på bakken. Navnene på de identifiserte ofrene er oppført på monumentet og funnstedene for gravene i skogen er også avmerket med romertall. Hvert enkelt av de 27 funnstedene for graver er markert med små steinpyramider. På monumentet er det også oppgitt antall ukjente jugoslaviske og sovjetiske ofre. Med plasseringen inne i skogen blant tette og høyreiste grantrær gis de besøkende en opplevelse av Falstadskogens historie, som er unik.

Begge monumentene på Falstad gir historien om krigsfangene et bredere perspektiv, fra det lokale til det regionale, og til det nasjonale og internasjonale. Til tross for at begge monumentene i Falstadskogen minnes alle nasjonaliteter, og at over dobbelt så mange østeuropeiske som norske fanger ble henrettet her, er det i hovedsak norske ofre, og til dels jugoslaviske ofre, som knyttes til den offentlige erindringen om Falstad i krigsårene. De sovjetiske ofrene har ikke vært knyttet til den offentlige erindringen i samme grad som de andre nasjonalitetene. Monumenter fungerer derfor ikke alltid som en kollektiv hukommelse, men også som en prosess hvor nasjonen glemmer. Ved å benytte begrepet sammenbrakte erindringer tilknyttet Falstadskogen, er sjansen større for også å kunne inkludere andre nasjonaliteter i vår erindring omkring okkupasjonsårene.

488 Ibid.: 6 . 
Ved å inkludere andre nasjonaliteter åpner vi også opp for andre tradisjoner i måten å skulle erindre og hedre krigens ofre på. I Falstadskogen har ikke minnemarkeringer for de østeuropeiske krigsfangene vært fraværende, men de har ikke vært særlig synlige for et bredere publikum i et nasjonalt perspektiv. Ved et besøk i 1969 oppdaget sønnen til et av de jugoslaviske ofrene farens navn på minnesteinen i skogen. Frem til dette tidspunktet hadde ikke familien hatt noe informasjon om hvor faren døde. Ti år senere var offerets enke Nada Grozdanovic i Falstadskogen, hvor hun la ned brød på mannens grav. Enken forklarte at hun gjorde dette fordi mannen forlot hjemlandet sulten, han døde sulten, og hun hadde aldri fått anledning til å hjelpe ham da han trengte det. Flere av de jugoslaviske krigsfangene som lyktes å flykte fra leiren, har senere vært tilbake ved monumentene i skogen. I 1971 var Jovan Stefanovic tilbake, og i 1995 var Petar Krasulja med på frigjøringsjubileet, der han la ned jord fra Jugoslavia på monumentet i Falstadskogen.

Folk husker de hendelsene som kulturen deres forventer at de skal huske. Det eksisterer felles mekanismer som kontrollerer erindringsformene våre og foreslår hva det er som er verdt og viktig å erindre. ${ }^{489}$ Bruken av erindringssteder i nasjonal kontekst gir oss gode muligheter til å undersøke erindringsprosessene i et samfunn. Falstadsenteret er en viktig arena i tolkningen av det norske samfunnets kollektive minne om østeuropeiske krigsfangers skjebne på norsk jord. Falstad som sted er også en viktig del av vår forståelse av det tyske leirsystemet som fenomen både nasjonalt og internasjonalt. For de jugoslaviske krigsfangene var Falstad en dødsleir. Denne fangegruppen hadde en dødsprosent på over 90 prosent i leiren. Dette var politiske fanger, og tyskerne tok derfor ikke hensyn til Genèvekonvensjonene i behandlingen av disse krigsfangene. Størsteparten av jugoslavene som endte opp på Falstad, var serbiske partisaner. Av 75 identifiserte jugoslaviske ofre som ble henrettet i Falstadskogen, var det 51 (68,9 prosent) serbere, 17 (23 prosent) bosniere, 5 (6,7 prosent) kroater og 2 (2,7 prosent) fra Kosovo.

Norsk Jugoslavisk Samband tok i 1983 initiativet til etableringen av Falstad museum. Man konsentrerte oppmerksomheten rundt det at bare syv jugoslaver overlevde fangeoppholdet på Falstad, og at det ikke var meningen at noen av de 4000 jugoslaviske fangene skulle overleve i Norge. Jugoslaven Ljuban Vukovic bidro med opplysninger om de jugoslaviske fangene på Falstad kort tid etter frigjøringen. Tyskerne hadde satt ham til å grave fangegraver i Falstadskogen. I Trøndelag ble de jugoslaviske ofrene flyttet til kirkegårdene på Lademoen og Moholt i Trondheim, inkludert ofrene fra Falstadskogen.

489 Ollila, Anne: «Introduction: History as Memory and Memory as History», i Studia Historica 61, 1999: 9. 
Det som skjedde på Falstad i krigsårene, formidles ulikt avhengig av hvem som tar på seg oppgaven med å bringe fortellingene videre og hvilket fokus og hvilke opplevelser som velges. Adresseavisen omtalte i juni 1945 Falstadskogen som «Gestapos Katynskog i Ekne». Avisen meddelte at massehenrettelsene i skogen var «et av de svarteste kapitler av tyskernes barbari overfor overvunne motstandere og annerledes tenkende eller uønskede individer. I løpet av halvannet år ble over 200 mennesker myrdet og lagt i godt skjulte graver inne i den uhyggelige myrete skogen.» ${ }^{490}$ I avisen kunne man lese om henrettelsene av 10 nordmenn fra Trondheim under unntakstilstanden i 1942 og mishandling av jugoslaviske fanger. Artikkelen er svært detaljert og viser det tydelige behovet for offentlig informasjon om tyske krigsforbrytelser umiddelbart etter frigjøringen. Det kan synes som om fortellertradisjonen fra fangenskap på Falstad har blitt opprettholdt av noen få nordmenn, og at de har skapt en hovedfortelling som skildrer det dramatiske og tragiske ved fangelivet i leiren. Det er gjerne knyttet til henrettelsene i Falstadskogen at de østeuropeiske fangene blir nevnt, og ikke når det fortelles om tilværelsen i fangeleiren. Et mer helhetlig bilde av fangelivet er viktig og gir oss ikke minst kunnskap om grove brudd på grunnleggende menneskerettigheter $\mathrm{i}$ krigsårene. Dette vil også kunne bringe frem ny forståelse og innsikt om det tyske krigsfangesystemet som ble etablert i Norge under krigen. Falstadsenteret er en viktig aktør i formidlingen av krigens fangehistorie i internasjonal sammenheng. Erindringsstedet Falstadsenteret minner mye om andre minnesteder, eller såkalte «Gedenkenstätte», som i etterkrigstiden er blitt etablert på kontinentet. I omfang er hendelsene på Falstad selvsagt noe helt annet enn de store utryddelsesleirene som ble etablert ellers i Europa, men dokumentasjons- og formidlingsarbeidet ved disse stedene har lange tradisjoner og er viktig for utviklingen av vår egen formidling av krigens fangehistorie i Norge. I denne formidlingen er stedliggjøring av historien et viktig virkemiddel.

Opplevelsen av Falstad som erindringssted avhenger av den enkeltes fortolkning av både Falstad-bygget, museet og skogen. Samlet sett representerer de et erindringssted som inkluderer mange nasjonaliteter. I tidsrommet november 1941 til mai 1945 var hele 13 nasjonaliteter representert i fangebelegget på 4500 fanger i leiren. Omkring 900 utenlandske krigsfanger ble sendt til Falstad fangeleir, og størsteparten av disse kom fra Sovjetunionen, Jugoslavia, Polen og Danmark. En viss andel av de østeuropeiske krigsfangene ble sendt videre til Oslo og fangeleiren Grini etter et kort opphold på Falstad. Fangekartoteket viser blant annet at flere polakker ved samme arbeidsbataljon i Sandnessjøen ble sendt derfra til Falstad og videre til Oslo på grunn av kontakt med norske kvinner. Kartoteket viser også at mange 490 Adresseavisen, 13.06.1945. 
sovjetiske og jugoslaviske krigsfanger hadde et opphold på Vollan fengsel i Trondheim før de ble sendt til Falstad. Etter kortere eller lengre opphold i Falstadleiren ble også en stor andel av de østeuropeiske fangene sendt videre til ulike leirer i Trondheims-distriktet for å utnyttes som arbeidskraft i leirer underlagt Organisation Todt. Med sin funksjon som gjennomgangsleir lokalt og regionalt representerer Falstad et viktig sted for formidling av kunnskap om de østeuropeiske krigsfangenes historie så vel på lokalt nivå som nasjonalt og internasjonalt.

Falstad museums utstilling var plassert i Falstad-bygningens kjeller i årene 1995-2006, og målet har vært å formidle krigens fangehistorie utfra et bredt perspektiv. Til tross for begrenset plass har utstillingen satt fokus på en rekke områder, som hverdagsliv i leiren, tysk behandling av de ulike fangekategoriene, «Det nasjonalsosialistiske leirsystemet» i Europa, retterstedet Falstadskogen og oppgravingene av ofrene, lokalbefolkningens hjelp til fangene og frigjøringsdagene i mai 1945. Museet har delvis klart å gjenskape og bevare erindringen om de østeuropeiske krigsfangene på Falstad. De la vekt på at bare syv jugoslaver overlevde fangeoppholdet på Falstad, og at det ikke var meningen at noen av de 4000 jugoslaviske fangene skulle overleve i Norge. I tilknytning til de sovjetiske krigsfangene viste utstillingen til antallet døde i Falstadskogen og hvor mange som var i live blant denne fangekategorien i 1945. Antakelser om de sovjetiske krigsfangenes videre skjebne etter frigjøringen ble formidlet ved at de reiste "frå eitt terrorvelde til eit anna». ${ }^{491}$ Et stort kart som viste en stor andel av krigsfangeleirene i Norge og Vest-Europa, var et viktig middel for å vise kompleksiteten ved leirsystemet, samt sette forholdene omkring leirene i Norge i en internasjonal kontekst.

Til tross for at de østeuropeiske krigsfangene var synlige i utstillingen, har ikke kunnskapen om dem vært synliggjort i det offentliges erindring på et lokalt og nasjonalt nivå. Det var erindringen om de 43 henrettede nordmennene i Falstadskogen som ble knyttet til utstillingen og den skriftlige formidlingen på Falstad ved frigjøringsjubileet. Det ble opplyst at på Falstad satt også jugoslaviske, sovjetiske og andre fanger fra det tyskokkuperte Europa, men en nøyde seg bare med å konstatere at «om Falstadfangene fra andre land vet vi foreløpig lite». ${ }^{492}$ Det er imidlertid tilfelle at overlevende norske fanger har skrevet om sitt møte med de østeuropeiske krigsfangene på Falstad, men dette materialet ble ikke tatt med i utstillingen. Opplysninger om de jugoslaviske fangene på Falstad ble også kort tid etter frigjøringen gitt av jugoslaven Ljuban Vukovic, som tyskerne hadde satt til å grave fangegraver i Falstadskogen. Et fåtall jugoslaviske fanger som klarte å flykte fra henrettelser

${ }^{491}$ Falstad museum utstilling 1995-2004. Utformet av scenograf Worm Winther. 492 Ibid. 
i skogen, har også bidratt til å avdekke skjebnen til de jugoslaviske fangene på Falstad. En nærmere undersøkelse av fangekartoteket viser at også sovjetiske sivile, kvinnelige tvangsarbeidere ble sendt til Falstad. Ved et tilfelle ble en ukrainsk kvinne sendt fra Hammerfest til Tromsø og videre til Falstad og et fangeopphold der på to måneder før hun til slutt ble sendt til Grini. Årsaken til at hun ble fengslet, var tyskfiendtlig holdning og brevveksling med en sovjetisk krigsfange. Det eksisterer ingen dokumentasjon om hvordan sivile sovjetiske kvinner ble behandlet i fangeleiren og deres videre skjebne etter oppholdet på Falstad.

På begynnelsen av 1990-tallet ble det påpekt at Falstad ikke bare var et nasjonalt anliggende, men også et internasjonalt minnested. Likevel ble ikke dette vektlagt i det videre arbeidet med utstillingen. En kan nok med rette hevde at den tidligere utstillingen fra 1995 var et produkt av sin tid og sine omgivelser, med en entydig tolkningsramme formet av en egen erindringskultur. Hovedvekten var tillagt det norske fangeperspektivet med en formidling av østeuropeiske krigsfangers historie i bakgrunnen og med hovedvekt på antall døde. Den samme erindringskulturen var karakteristisk for norsk okkupasjonsforskning omkring 50-årsjubileet for frigjøringen. Studier omkring østeuropeiske krigsfanger på norsk jord hadde startet, men det var for tidlig til at kunnskapen og erfaringene om emnet ble synliggjort i nasjonal offentlig sammenheng. Selv om denne fangekategorien i stadig større grad inkluderes i erindringen om okkupasjonen, er det fremdeles mye som mangler på at en kan si at minnet om disse skjebnene har blitt rehabilitert i den norske kollektive erindringen om krigen.

Falstadskogen representerer et erindringssted der ofrene både var av norsk og utenlandsk opprinnelse. Et sentralt spørsmål i denne sammenhengen er i hvilken grad dette har fått betydning for innholdet i de ulike minnemarkeringene i skogen. Er det de norske ofrene og det spesifikt norske knyttet til Falstad og okkupasjonstiden nasjonalt som er gjenstand for erindring i Falstadskogen?

I et fredningsforslag angående Falstadskogen ble det fra Nord-Trøndelag Fylkeskommunes side påpekt at:

Fremfor alt er Falstadskogen et minnested for internasjonal solidaritet. Minst 150 jugoslaviske og russiske krigsfanger ble skutt her (...) Svært mange av de jugoslaviske og russiske krigsfangene ble henrettet etter å ha blitt angitt av nordmenn mens de var på flukt. Falstadskogen er således et minne om mangel på lojalitet og solidaritet, ikke bare på norsk, men også internasjonal grunn. 

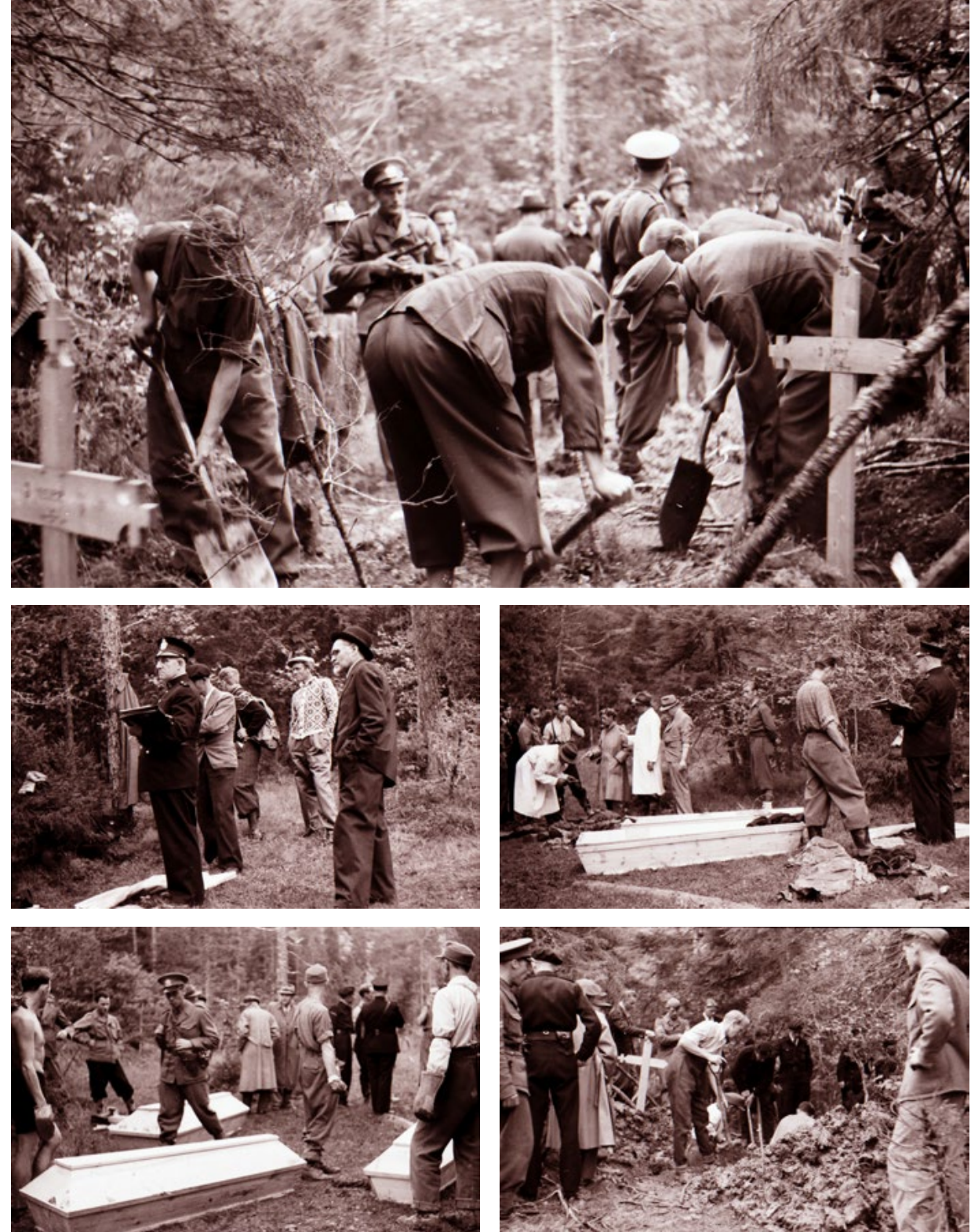

Oppgravingen i Falstadskogen 1945. Foto: Oskar A. Johansen, Falstadsenteret.

Ifølge tall fra Krigsgravtjenesten ble 97 sovjetiske, 66 jugoslaviske krigsfanger og 43 nordmenn henrettet i Falstadskogen i krigsårene. Retterstedets nærhet til leiren var ikke i tråd med de tyske retningslinjene som fastsatte at krigsfanger ikke skulle henrettes i krigsfangeleiren eller i den umiddelbare nærheten av leiren. Skogen og retterstedet skaper en egen stemning for erindring om ofrene for tysk brutalitet som det er vanskelig å forbli upåvirket av.

Sommeren 2003 ble det for første gang holdt en minnestund med ortodoks liturgi ved monumentet fra 1947 i Falstadskogen. Flere biskoper fra Den serbisk-ortodokse kirken i Sverige gjennomførte minnestunden. Tradisjonen 
med bruk av sang og røkelse gjorde dette til en spesiell minneseremoni. Sovjetisk deltakelse ved minneseremonier i Falstadskogen har ikke vært så synlige i det offentlige rom. Ved frigjøringsjubileet i 1985 ble det lagt ned en krans ved monumentet på vegne av en sovjetisk krigsfange som hadde vært fange på Falstad. Hvert år den 1. mai legger også Den russiske ambassaden i Oslo og LO Levanger ned krans ved monumentet. Denne typen minnemarkeringer blir aldri presentert i den brede offentligheten, og dermed får de preg av et nærmest privat initiativ og forblir en ukjent del av erindringsstedet. På den russiske frigjøringsdagen den 9. mai 2004 besøkte en gruppe russiske studenter Falstadskogen. En av studentene uttalte at hun hadde fătt et veldig godt inntrykk av hvordan nordmenn hedrer minnet om de som ble henrettet i skogen. Senere samme år besøkte den første gruppen med hviterussiske skoleelever Falstadskogen, og via dette besøket fikk Falstadsenteret også kontakt med Vasilij Shevtsjenko, som hadde vært krigsfange på Falstad i 1944. Slike besøk er svært viktige ikke bare for senterets formidling av Falstadskogens internasjonale historie, men også fordi de gir en god mulighet til å skaffe kunnskap om kollektiv erindring og erindringssteder knyttet til andre verdenskrigs ofre i dagens Russland og Hviterussland.

\subsection{Jørstadmoen sovjetiske krigskirkegård}

Jørstadmoen sovjetiske krigskirkegård ble opprettet av de tyske okkupasjonsmyndighetene under krigen. Ifølge tyske, sovjetiske og norske kilder er 954 ofre gravlagt på Jørstadmoen. Av disse er det registrert 928 sovjetiske, 25 jugoslaviske og to polske blant dem som er gravlagt. Den første som døde, ble gravlagt 20. april 1942, og den siste ble gravlagt den 23. mai 1945. Samtlige av ofrene bortsett fra en er identifisert ved navn. Krigskirkegården ligger på grunn som er eid av Forsvarsbygg, men utenfor militært område. Det er fri adgang til krigskirkegården. Vedlikeholdet av krigskirkegården ble tidligere ivaretatt av Jørstadmoen garnison ved hjelp av vernepliktig mannskap som tjenestegjorde i leiren. Etter en omorganisering av eiendomsdriften i Forsvaret og endret bruk av Jørstadmoen leir, var det i 2010 behov for en endring av ansvaret for vedlikeholdet og forvaltningen av krigskirkegården. Ifølge Krigsgravtjenesten var det naturlig at Forsvarsbygg tok på seg ansvaret for vedlikeholdet. ${ }^{493}$ Minnesmerket på Jørstadmoen ble oppført av lokale myndigheter etter krigen. I tillegg til fellesmonumentet har Jacob Schakirov fått et eget gravminne. På skiltet ved graven er det skrevet: «Jacob Schakirovs grav, døde 8. mai 1945. Noen dager senere plantet kamerater små gran-

${ }^{493}$ RA, Krigsgravtjenesten, brev til Forsvarsbygg. «Vedlikeholdsordning for Jørstadmoen sovjetiske krigskirkegård». 16.12.2010. 
for de nye minneplatene og rydding av krigskirkegården. Deres håp var at de nye minneplatene ville være på plass våren 2012, som var 70 år etter at de første fangene ble gravlagt på Jørstadmoen. ${ }^{496} \mathrm{I}$ dag er det Forsvarsbygg som har ansvar for vedlikeholdet av krigskirkegården, men det er ingen planer om merking av gravene.

I mai 2012 strødde Ole Rønning fra historielaget jord fra Ukraina på krigskirkegården. Seremonien var til minne om Grigori Fjodorovitsj Malakov, som døde på Jørstadmoen 23. oktober 1942. I 69 år var familien uvitende om hvor det hadde blitt av den ukrainske snekkeren som ble innkalt til tjeneste i Den røde armé i 1941. Først da datteren Valentina fikk se farens navn i en avis i hjemlandet, fikk familien vite hva som hadde skjedd med ham. For både russere og ukrainere betyr det mye at gravplassen til deres kjære får jord fra hjemlandet, og Valentina var svært takknemlig for at historielaget tok seg tid til å utføre hennes ønske om å legge jord på farens gravsted i Norge. ${ }^{497}$

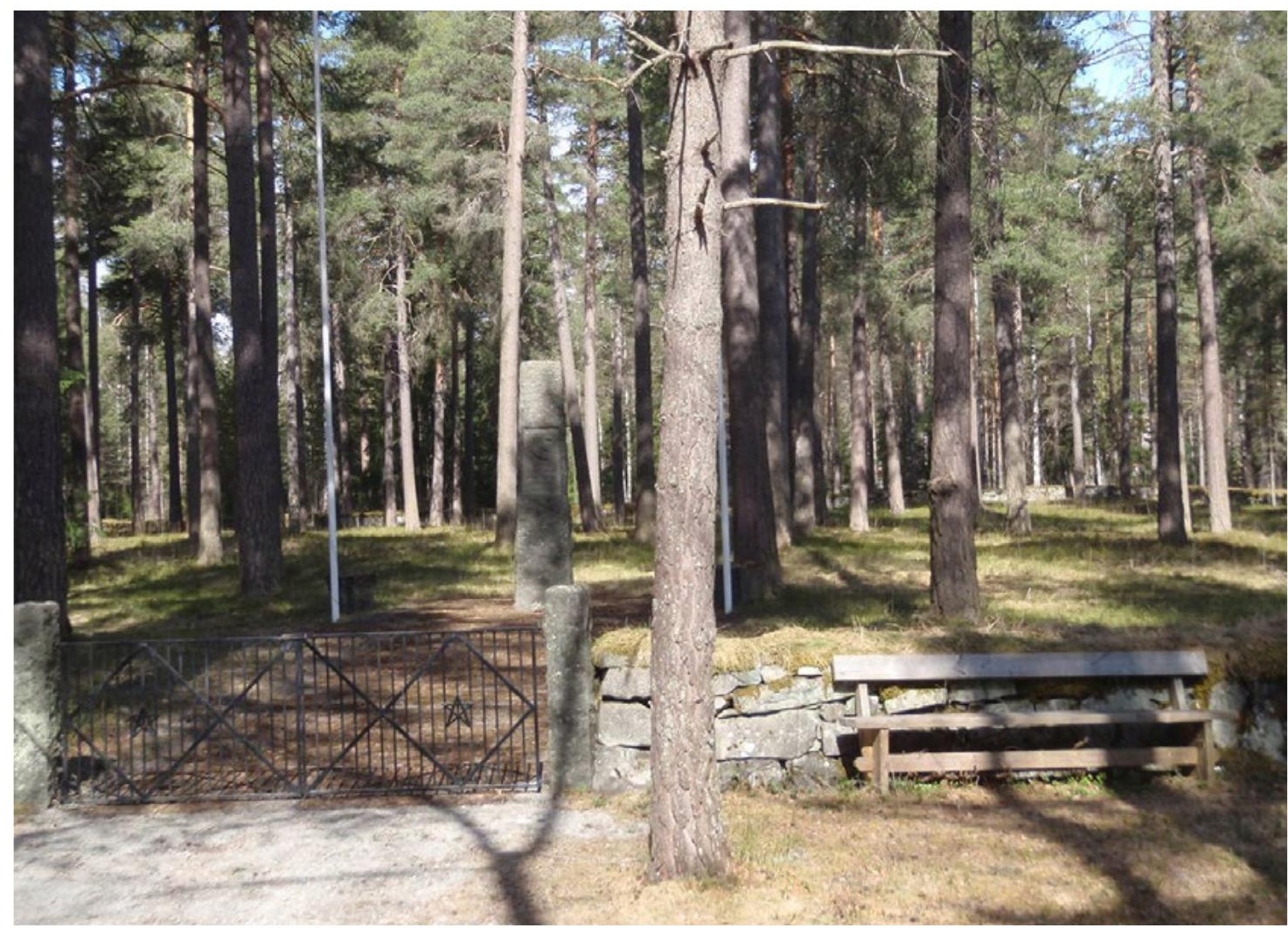

Jørstadmoen sovjetiske krigskirkegård 2010. Foto: Per-Otto Gullaksen.

${ }^{496}$ FAD, Krigsgravtjenesten. Saksnr. 10/4464-4. Brev fra Fåberg og Lillehammer historielag. Lillehammer 24.09.2011.

${ }^{497}$ Gudbrandsdølen Dagningen, 10.05.2012. 


\section{4 Østeuropeiske ofre i dagens minnekultur i Europa}

Minnet, forvaltningen og bruken av sovjetiske, jugoslaviske og polske krigsgraver i Europa viser hvordan utviklingen av minnet om krigens ofre har vært i disse områdene.

Veteranene etter slaget ved Kursk ble i etterkrigsårene sett på som vinnere. De gikk ikke gjennom krigen som krigsfanger eller som domfelte fra en straffebataljon. Disse veteranenes styrke har vært at de kan snakke om skyttergraver, snikskyttere og skader, skriver Catherine Merridale i boken Ivan's War. ${ }^{498}$ Men ingen av dem seilte gjennom krigen uskadet. Russland er ikke det eneste landet som har betalt en høy pris for Hitlers krig. Ifølge Merridale fortsetter det å ha betydning for folket i Ukraina at de var den nasjonale gruppen som bar det største antallet sivile tap på sovjetisk side. I Hviterussland mistet enkelte byer en fjerdedel av befolkningen. I disse republikkene er minnet knyttet til disse dødsfallene fortsatt viktig. Det er et bittert og personlig minne for de millionene som overlevde nazistenes brutalitet, og markeringen av ofrene er en sentral del av den offentlige, kollektive hukommelsen. Historien er litt annerledes for russerne. Krigen var hovedsakelig Russlands krig, og en skiftende politisk kontekst har påvirket måten krigen er erindret på og presentert i dagens Russland. Det er fortsatt mye motstand i Russland til nytolkninger av krigen. Den russiske regjeringen har interesse av å bevare et positivt bilde av krigen som sin seier over nazismen, som fortsatt er den største bragden det moderne Russland kan skilte med. Offisielle sovjetiske beretninger sier ingenting om soldatenes traumer, nerver på slagmarken eller depresjon i ettertid. ${ }^{499}$

Etter Sovjetunionens fall ble det igjen tillatt med religiøse metaforer tilknyttet minnet om andre verdenskrig, og dette var statlig støttet. Det beste eksempelet her er seiersfesten ved 50-årsjubileet med markeringen av det lenge planlagte sentralmuseet for den store fedrelandskrigen, som ble åpnet den 9. mai 1995 i Moskva. Det sovjetiske offeret knyttet til krigen ble fremstilt som et spesifikt russisk offer i form av et minnekapell, oppkalt etter den militære skytshelgen St. George. Museet og kirken er dedisert til de falne. Det sekulære og det hellige ble satt i sammenheng og ble ansett for å være uatskillelige frelsere av landet. ${ }^{500}$ Minnehallen i underetasjen på museet er laget for å hedre minnet om 26 millioner døde eller savnede sovjetiske stats-

498 Merridale, Catherine: Ivan's war. Faber and Faber, London, 2006: 334.

499 Ibid.: 324-327.

500 Carleton, Gregory: «Victory in death. Annihilation narratives in Russia today», i History \& Memory, Vol. 22, No. 1 (Spring/Summer 2010): 158. 
borgere. I midten av hallen er det plassert en hvit skulptur som symboliserer sorg. Skulpturen er «Den russiske mor», som sørger over en død soldat. På begge sider av hallen er det satt opp glassmontere med minnebøker fra ulike regioner i det tidligere Sovjetunionen. Navnene på millioner som omkom eller var savnet i kamp i løpet av krigsårene, er registrert i bøkene. En elektronisk minnebok med navnene er også tilgjengelig for de besøkende på museet.

I det siste tiåret har det vært en stadig økende oppmerksomhet rundt sivilbefolkningens lidelser under andre verdenskrig, mer enn hva som var tilfellet i det tidligere Sovjetunionen. Eksempler på dette er russiske historiebøkers fremstilling av de siviles innsats og bruk av erindringssteder, som viser utviklingstrekk ved den historiske bevisstheten om både sivile og militære tap. Studier av kollektiv erindring i dagens Russland viser til sentrale historiebøker som fra 1995 har lagt vekt på det russiske folkets heltemot og lidelser. ${ }^{501}$ Folket ble fremstilt som den avgjørende faktoren i kampen mot tyskerne. Til tross for at de siviles lidelser i det tidligere Sovjetunionen har fått en plass i dagens russiske kollektive erindring, er det fremdeles mange såkalte hvite flekker i krigserindringen og den historiske bevisstheten. Emner som skjebnen til ulike befolkningsgrupper i etterkrigstiden, repatrieringen av sivile tvangsarbeidere og krigsfanger, krigsinvalider og Vlasov-soldater er i liten grad blitt dokumentert. ${ }^{502}$

Minnestedet Hatyn utenfor Minsk i Hviterussland er blitt et symbol på minnet om alle krigens ofre, både de sivile og militære, i Hviterussland. Stedet er også et minnested for sovjetiske krigsfanger som døde i tyske fangeleirer

501 Wertsch, James V.: Voices of Collective Remembering. Cambridge University Press, Cambridge 2002: 110-111.

502 Scherrer, Jutta: «Siegesmythod versus Vergangenheitsaufarbeitung», i Mythen der Nationen. Bd. 2. Deutsches Historisches Museum, Berlin 2004: 655. 
i Hviterussland. Totalt døde 2,2 millioner mennesker i Hviterussland i løpet av krigsårene 1941-1945. For en besøkende fremstår dette i dag som et sted med sterke symbolske uttrykk i form av flere monumenter og rekonstruksjoner. Historien til selve stedet er tyskernes utslettelse av en hel landsby med 149 innbyggere hvorav 75 var barn. En eldre mann og to barn overlevde. Hovedmonumentet er en enorm skulptur av den eldre mannen som bærer på sin

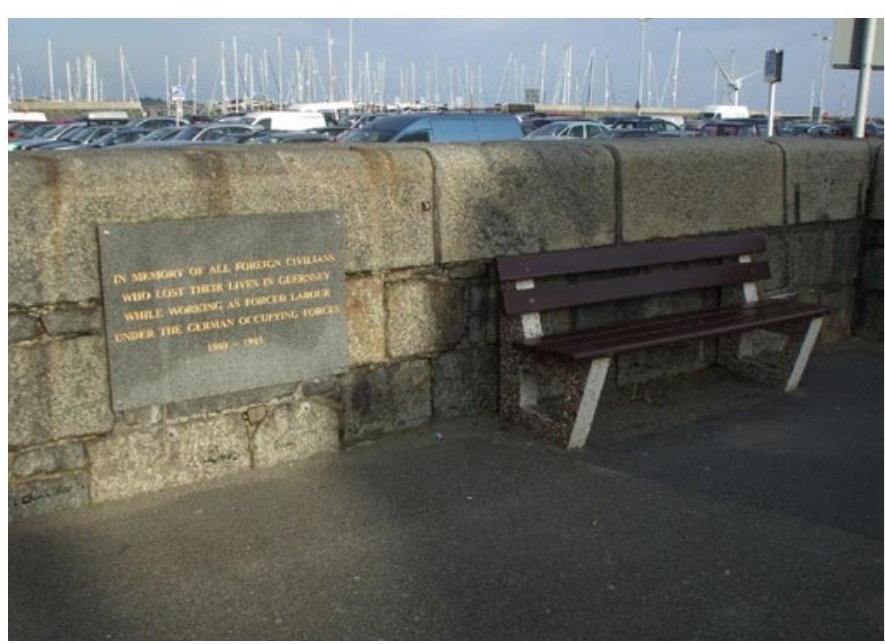

Minnesmerke, Foreign Labourer Memorial, St Peter Port Guernsey 2008. Foto: Gilly Carr. døde sønn som han har funnet blant ofrene. Til minne om 186 andre landsbyer som ble ødelagt og aldri gjenoppbygd, er det samlet jord fra hver landsby. En stor mur er oppført med navn på fangeleirer og steder for masseutryddelser i Hviterussland. Ved en evig flamme er det plantet tre bjørketrær som symboliserer at hver fjerde innbygger mistet livet under andre verdenskrig i Hviterussland. Dette erindringsstedets imponerende arkitektoniske utforming er i sterk grad et symbol på nasjonal patriotisme. Med et uttrykksfullt og konsist språk forteller monumentene om det hviterussiske folkets tragedie og mot i krigsårene. Hvert hus i landsbyen er rekonstruert i form av en lav mur og en klokke i husets murpipe som ringer med korte intervaller. Navnene på ofrene kan vi lese på en minnetavle ved hvert enkelt «hus». I brosjyren til minnestedet Hatyn fremheves det at minnet her er ikke bare knyttet til de døde, men også til stoltheten, motet og motstanden til det hviterussiske folket. Hatyns internasjonale kontekst formidles med en henvisning til at den sorgfulle lyden av klokkene skal minne oss om skjebnene i ukrainske Kortelisy, italienske Marzabotto, greske Kalavrita, tsjekkiske Lidice og norske Telavåg.

En helt annen tradisjon og uttrykk knyttet til minnesmerkene over utenlandske tvangsarbeidere finner vi på Kanaløyene sør for England. I forbindelse med «Atlantic Wall», som var tyskernes største forsvarsprosjekt i Europa, bygde den tyske okkupasjonsmakten og Organisation Todt festningsverker rundt kysten av Kanaløyene fra 1940 til 1945. Flertallet av arbeidsstokken var tyske soldater, men rundt 1000 sovjetiske krigsfanger ble brukt som slavearbeidere. Minnet om tysk mishandling og tortur av slavearbeiderne er 
fortsatt levende hos dem som opplevde krigsårene på Kanaløyene. Organisation Todts utenlandske arbeidstakere fikk et offentlig minnesmerke først i 1999 på Guernsey utenfor kysten av Frankrike, nesten 60 år etter deres ankomst. Situasjonen på naboøya Jersey er bedre, der tidligere Organisation Todt-arbeidere oppførte det første minnestedet til minne om deres døde kamerater i 1970, som var 25-årsjubileet for frigjøringen. De utenlandske slavearbeiderne ble plassert, for det meste, i leirer rundt på Jersey, Guernsey og Alderney, som er den nordligste av kanaløyene. Bare et av disse tidligere fangeleirområdene er blitt gjenstand for oppmerksomhet i ettertid. Det er den tidligere konsentrasjonsleiren Sylt på Alderney, den eneste konsentrasjonsleiren på britisk jord. På det tidligere leirområdet ble en plakett oppført så sent som i 2008. Alle andre leirområder for slavearbeiderne på Kanaløyene er nå boligfelt eller grundig overgrodd. ${ }^{503}$

I leiren Norderney på Alderney satt østeuropeiske og spanske tvangsarbeidere i fangenskap. Lager Borkum ble brukt til tyske teknikere og såkalte frivillige fra forskjellige land i Europa. I Lager Helgoland var det i hovedsak fengslet sovjetiske tvangsarbeidere som tilhørte Organisation Todt. I Lager Sylt var det plassert jødiske tvangsarbeidere. Totalt var det 6000 arbeidere, krigsfanger og tvangsarbeidere i disse leirene på Alderney. Fangene i Lager Norderney og Lager Sylt ble satt til å bygge militære festningsbygg og installasjoner over hele Alderney. I 1942 ble begge leirene satt under kontroll av SS Hauptsturmführer Max List. Over 700 av de innsatte mistet livet før leirene ble stengt, og de resterende innsatte ble overført til Tyskland i 1944.

Statlige myndigheter på Alderney nektet å gjennomføre offentlige arrangementer til minne om de fire tvangsarbeidsleirene. Lokalhistorikeren Colin Partridge mener dette kan skyldes lokalbefolkningens ønske om å distansere seg fra anklagene om samarbeid med tyskerne. En falmet minneplate, gjemt bort bak øyas kirke, nevner vagt 45 sovjetiske borgere som døde på Alderney i 1940-1945, uten å si hvordan eller hvorfor de døde.

På Jersey er det etablert et minnesmerke i Westmont til minne om ofrene for slavearbeid fra Spania, Polen, Russland og andre land. I 1975 ble minnesmerket, som står den dag i dag, bygd med midler fra Public Health Committee og myndighetene i ofrenes hjemland. Det russiske minnesmerket ble erstattet med et annet fra den sovjetiske ambassaden i London. Det nye minnesmerket ble plassert på gravstedet til sovjetiske tvangsarbeidere som døde på Jersey. I tilknytning til det russiske minnesmerket holdes det hvert år et arrangement på frigjøringsdagen den 9. mai, som også er en offentlig fridag. En høytstående militær tjenestemann fra den sovjetiske ambassaden

503 Carr, Gilly: «The slowly healing scars of occupation», i Journal of war and culture studies. Vol 3, nr. 2. 2010: 250-251. 
deltar sammen med representanter for offentlige instanser som representerer familiene til de avdøde. Noen overlevende tidligere slavearbeidere deltar fortsatt på seremonien. ${ }^{504}$

På Kanaløyene er det fortsatt tidligere leirområder som har vært skjult eller forsømt i lang tid. Andre har blitt ødelagt og har forsvunnet helt, slik som de tidligere leirområdene som tilhørte Organisation Todt. Disse områdene utgjør en sentral del av hva en kan kalle glemselens politikk omkring krigsminnene på Kanaløyene. Det ville være vanskelig å finne en måte å gjenopprette et tidligere leirområde der det i ettertid er blitt bygd en bungalow. Dette er tilfelle med Lager Helgoland på Alderney. For områder som dette må muligens denne gjenopprettingen skje ved hjelp av enkeltpersoner. En mulig vei å gå er å invitere tidligere krigsfanger eller slavearbeidere til stedene der de opplevde mye personlig smerte, slik at de kan fortelle om sine opplevelser i fangeleirene. ${ }^{55}$ Disse eksemplene omkring minnene om de utenlandske ofrene på Kanaløyene gir et klart bilde av hvor forskjellig øyene Alderney og Jersey har klart å håndtere denne delen av deres okkupasjonshistorie.

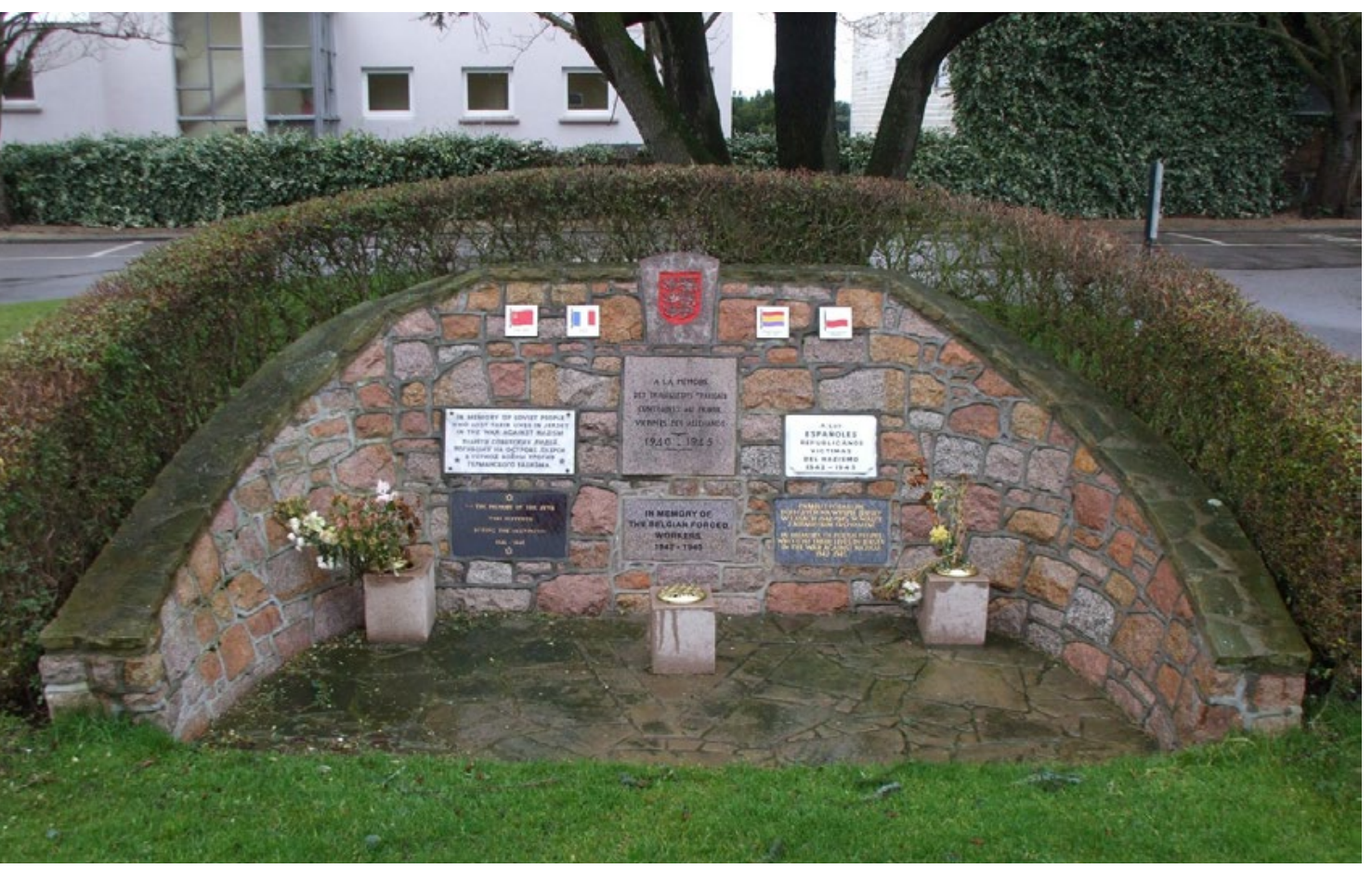

Minnesmerke, Slave Worker Memorial, St Helier Jersey 2012. Foto: Gilly Carr.

$504 \mathrm{http}: / /$ jersey.com/english/discoverjersey/occupationtoliberation/memorial/pages/default. aspx. (lest 10.10.2013).

505 Carr, Gilly: "The slowly healing scars of occupation», i Journal of war and culture studies. Vol 3, nr. 2. 2010: 263. 
Den franske historikeren Pierre Nora viser til et utvidet begrep om kollektiv erindring, ${ }^{506}$ som er viktig i erindringsprosessen omkring krigens fangehistorie. I tillegg til minnestedene er ulike institusjoner og gjenstander sentrale for erindringen. Monumenter, minnemarkeringer og utstillinger kan tjene som sentrale steder som gir mulighet til å bevare erindringen og gi kunnskap om krigsfangene. Problemet er imidlertid at de ikke makter å skape en felles erindring som inkluderer alle nasjonalitetene blant fangekategoriene på et nasjonalt nivå. På den ene siden er de sovjetiske krigsfangene et fremmed og glemt emne innen norsk okkupasjonshistorie, men på den annen side er deres historie velkjent via muntlig og skriftlig dokumentasjon på lokalt nivå. Men, denne lokale kunnskapen er ikke blitt brukt i et videre perspektiv, og resultatet er en begrenset erindring. Det har for eksempel ikke vært rom for en levende erindring om de sovjetiske krigsfangene på nasjonalt nivå i det norske samfunnet. Rett etter frigjøringen i 1945 var de sovjetiske krigsfangene gjenstand for en allmenn oppmerksomhet og sympati. De forsvant langt på vei fra det kollektive minnet frem mot 1970, men ble fra midten av 1980-årene igjen gjenstand for oppmerksomhet. Siden slutten av 1980-tallet har bevisstheten og kunnskapen om denne fangekategoriens skjebne i Norge vært økende, men bidragene har vært fragmentariske. Fra begynnelsen av 1990-tallet har vi flere eksempler på sovjetiske krigsfanger som har tatt kontakt med eller er blitt kontaktet av privatpersoner i Norge, og kommet tilbake for å minnes tiden som krigsfange her i landet.

Hva angår erindringen om de jugoslaviske fangene, er bildet noe annerledes. I motsetning til de sovjetiske krigsfangene ble de jugoslaviske tatt imot som helter etter hjemkomsten. Men tilbake i Jugoslavia fikk de hjemvendte frigitte fangene mer enn nok med en ny hverdag og gjenoppbyggingen av et sønderskutt land. Sommeren og høsten 1945 ble det etablert norsk/ jugoslaviske sambandsorganisasjoner i Oslo, Trondheim og Mo i Rana, men kontakten mellom tidligere jugoslaviske fanger og nordmenn var det første tiåret etter frigjøringen forholdsvis sporadisk og tilfeldig. Særlig fra slutten av 1950-årene begynte enkelte tidligere jugoslaviske krigsfanger å komme tilbake til Norge. Årsaken var både lettere politiske forhold og bedret økonomi i Jugoslavia. Den gode kontakten mellom nordmenn og jugoslaver eller jugoslaviske organisasjoner som utviklet seg etter dette, har bidratt til å opprettholde erindringen om denne gruppen. De jugoslaviske krigsfangenes skjebne på norsk jord er godt kartlagt i norsk forskning og erindringslitteratur skrevet av overlevende fanger. På slutten av 1960-tallet ble Norsk jugoslavisk samband reorganisert og aktiviteten til organisasjonen økte raskt. I byen Gornji

506 Nora, Pierre (red.): Les lieux de mémoire. Columbia University Press, New York 19841992. 
Milanovac i Serbia ble det i 1987 etablert et norsk/jugoslavisk kulturhus og reist et stort monument til minne om de over 2300 serbiske krigsfangene som døde i Norge i årene 1942-45. Den gode kontakten mellom Norge og det tidligere Jugoslavia hadde også bakgrunn i et godt myndighetssamarbeid.

De polske krigsfangene har delvis blitt skildret i norsk okkupasjonshistorie, men denne gruppen har ikke hatt et synlig behov for å holde kontakten med Norge etter hjemsendelsen i 1945. Likevel har polsk forskning vist at polske tvangsarbeidere som ble sendt til Norge under okkupasjonen, fremdeles holder kontakten med norske familier. 


\section{Avslutning}

Den store massen av sovjetiske krigsfanger og dødstallene blant dem representerte en annen side ved krigens virkelighet enn hva en ellers hadde vært vitne til her i landet siden krigen startet. De lange rekkene av utsultede og avkreftede fanger kledd i fillete uniformer på vei til tungt arbeid var et rystende syn. Nordmenn ble konfrontert med en brutalitet uten sidestykke, og mange følte at dette var den største påkjenningen under den tyske okkupasjonen. Det var svært vanskelig å kartlegge nøyaktige dødstall over sovjetiske krigsfanger i tiden etter frigjøringen. Kun et fătall av de sovjetiske ofrene ble registrert med dødsårsak og personinformasjon. Norge var forpliktet til å følge de internasjonale reglene for merking av krigsgraver, og for å være på den sikre siden innhentet norske myndigheter informasjon om hvordan andre land hadde løst dette.

Samlingen av gravene før «Operasjon asfalt» ble en krevende oppgave for norske myndigheter. Det ble lagt vekt på at arbeidet skulle gi minst mulig kostnader for norske myndigheter, og man forsøkte å unngå at gravene ble flyttet til militære områder. Lensmennenes rapporter fra identifikasjonsarbeidet kort tid etter krigsslutt i Finnmark viste at det var vanskelig å få stadfestet dødsårsak eller samle inn opplysninger om behandlingen av krigsfangene. I kartleggingsarbeidet viste det seg at sovjetiske myndigheter var opptatt av å få hjemsendt falne sovjetiske soldater etter kampene i Sør-Varanger, men ikke døde krigsfanger. I Troms og Nordland økte antallet fanger etter evakueringen fra Finnmark og med dette økte også antallet døde i disse to fylkene. I Lyngen-området ble det avdekket at mange fanger var utsatt for krigsforbry- 
telser, og norske myndigheter anslo at flere hundre krigsfanger hadde blitt henrettet. I Nordland ble tyske soldater satt til å grave opp døde krigsfanger og dette skapte problemer med merkingen av gravene, siden ofrene kun ble samlet i massegraver. Samarbeidet mellom norske militære myndigheter og tyske soldater var dårlig, og det ble ikke laget noen oversikt over arbeidet som ble utført. Dette skapte kaotiske forhold i registreringen av antallet ofre, og det viste seg at rapportene fra sogneprestene ga bedre oversikt enn materialet fra de militære enhetene. Ved den første samlingen av gravene i Sør-Norge var ofrenes rett til et verdig gravsted og vedlikehold av gravene sentralt. Helsemessige og militærstrategiske hensyn var særlig viktig for flyttingen av gravene i blant annet Trøndelag og på Nordmøre.

Uenigheter mellom representantene i den norsk-sovjetiske krigsfangekommisjonen skapte diskusjoner om kommisjonens mandat. Dette utviklet seg til en diplomatisk dragkamp og norske myndigheter uttrykte sin skepsis til stadige uoffisielle sovjetiske besøk knyttet til områder med krigskirkegårder. Det var særlig i militære områder at dette skapte misnøye, og forsvaret i Nord-Norge ga klar beskjed om at de måtte få informasjon om alle sovjetiske representanters reiser i deres ansvarsområde. Både politiet og lokale militære myndigheter skulle ikke svare direkte på forespørsler fra sovjetisk side, men henvise disse til Utenriksdepartementet eller Forsvarsdepartementet. I juni 1951 presenterte norske myndigheter den omfattende toårsplanen for samlingen av de sovjetiske krigsgravene. Denne planen ble raskt endret og Etterretningstjenesten opplyste at alle sovjetiske graver i de tre nordligste fylkene skulle flyttes til et gravsted i Vefsn. Flere alternative løsninger til gravspørsmålet ble presentert, men planen ble skrinlagt da Forsvarsdepartementet ikke ønsket så mange gravsteder. Ved en sterk konsentrasjon av gravene både $\mathrm{i}$ Nord- og Sør-Norge ønsket norske myndigheter å gjennomføre flyttingen på billigste måte og forhindre uønsket sovjetisk reisevirksomhet i landet.

Da gravene i Nord-Norge skulle samles i regi av «Operasjon asfalt», ble nye oversikter over antallet sovjetiske døde utarbeidet, men svært mange steder manglet det dokumentasjon som kunne gi eksakte antall. Det store antallet østeuropeere som døde på norsk jord under krigen, vitner om en brutal behandling av flere nasjonaliteter blant krigsfangene. Ødeleggelse av kildemateriale samt svært liten respekt for menneskeliv, som tydeliggjøres ved at krigsfanger ble kastet i fellesgraver eller knapt nok gravlagt av tyskerne, har komplisert rekonstruksjonen av dødstallene i ettertid.

«Operasjon asfalt» var en dramatisk hendelse knyttet til etterkrigserindringen om de sovjetiske krigsfangene. Operasjonen ble et eksempel på politiseringen av krigsfangenes historie. Norske myndigheters frykt for spionasje fra sovjetisk side var tydelig kort tid etter frigjøringen, og en blandet norsk-sov- 
jetisk krigsfangekommisjon var i seg selv et forvarsel om den kalde krigen. Gravsaken bidro til å skape et dårlig forhold mellom Norge og Sovjetunionen. Det norske forsvaret var åpenbart nervøse for at sovjetiske myndigheter skulle bruke sovjetiske krigsgraver som et påskudd for å få adgang til sensitive militære områder i Norge. Dette var et høyst overbevisende argument med tanke på at vi var i begynnelsen av den kalde krigen. Norske myndigheters frykt for spionasje og grunnløse argumenter for å gjennomføre operasjonen vitnet om en politikk preget av panikk.

Transporten av levningene ble svært vanskelig for de involverte. Mannskapenes fortellinger vitner om mye misnøye med for lave lønninger og svært vanskelige forhold under arbeidet. Arbeidet ble en påkjenning både psykisk og fysisk for mannskapene, og enkelte ville aldri deltatt hvis de hadde fått vite hva de hadde i vente. Lokale og sentrale myndigheter hadde heller ikke den beste kontakten, og dette skapte problemer for forsøkene på å ikke skape unødvendig oppmerksomhet underveis ved innlastingen og transporten til Tjøtta.

Forholdene omkring flyttingen av sovjetiske graver i Nord-Norge og den kalde krigen bidro til en usynliggjøring av sovjetiske krigsfangers skjebne på norsk jord. Krigsgravsaken skapte en kortvarig oppmerksomhet omkring krigsfangene, men den dukket opp på et tidlig stadium i den kalde krigen og bidro på lang sikt til at en viktig side ved norsk okkupasjonshistorie ble glemt. Minnesmerker og gravkors over ofrene ble fjernet og dermed var det små muligheter for nordmenn å holde minnet om fangene ved like. Med den kalde krigen og hendelsene omkring «Operasjon asfalt» ble grunnlaget for å bevare minnet om krigsfangene fjernet. Ødeleggelsen av minnesmerker og hemmelighold av oppgravingsarbeidet gjorde lokalbefolkningen i NordNorge til forskrekkede tilskuere til det de beskrev som makabre handlinger. Rent fysisk sett fjernet oppgravingen og ødeleggelsene det eneste som kunne danne grunnlaget for et verdig og varig minne om skjebnen til de tusener av sovjetiske krigsfanger som mistet livet i Norge i løpet av krigsårene.

I mange nordnorske aviser ble oppgravingen og flyttingen av gravene beskrevet, og flere rettet skarp kritikk mot fremgangsmåten og mangelen på pietet. Protester og demonstrasjoner i Narvik, Beisfjord, Harstad, Mo i Rana og Tromsø var uttrykk for den sterke sympatien blant nordmenn overfor sovjetiske krigsfanger som mistet livet i Norge. Men operasjonen førte på sikt til en svekkelse av den kollektive erindringen om fangene både lokalt og nasjonalt. I den første etterkrigstiden konsentrerte man seg om krigsfangenes lidelser og nordmenn som hjalp fangene i krigsårene, men nå ble dette et emne som tilhørte den kalde krigen. Flyttingen og fjerningen av krigsminnesmerkene resulterte i en svekkelse av nordmenns erindring om de sovjetiske krigsfangene. Minnesmerker som ble fjernet, var ikke lenger noen 
del av hverdagserfaringene, og følgelig skulle dette ikke gi grunnlag for en aktiv erindring om de sovjetiske krigsfangene på lokalt eller nasjonalt plan. Opprettelse og vedlikehold av gravmonumenter og minnesmerker over døde sovjetiske krigsfanger over hele landet var og er tydelig avhengig av lokale initiativ. Fravær av minnesmerker eller mangel på interesse for slike minnesmerker gir klare signaler om samfunnets vilje til å minnes hva som hendte andre nasjonaliteter på norsk jord under okkupasjonsårene.

Hendelsene i Mo i Rana viser hvor avgjørende det lokale engasjementet var for å kunne hindre en flytting av krigsgravene. Det representerte dessuten et uttrykk for styrken hos de lokale kommunistene og det sterke solidaritetsbåndet som hadde utviklet seg mellom befolkningen og de sovjetiske krigsfangene under krigsårene. Men motstanden mot flyttingen viser at dette engasjerte ikke bare kommunistene, men også resten av befolkningen. Selv om aksjonen skjedde flere år etter frigjøringen, var det en åpenbar aktiv erindring omkring de sovjetiske krigsfangene i Mo i Rana og de andre stedene hvor befolkningen protesterte mot flyttingen. Selv om kontakt mellom sovjetiske krigsfanger og lokalbefolkning hadde vært omfattende over hele landet, var det klart at denne typen protester krevde stor innsats, og muligens er det grunnen til at det aldri ble etablert noen motstand på nasjonalt nivå. Reaksjonene fra pårørende av ofrene og de overlevende fangene var gjerne knyttet til behovet for å vite hvor slektningene og kameratene deres var gravlagt. De var også opptatt av å få vite i hvilken grad minnestedene var vedlikeholdt og ivaretatt.

Sovjetiske myndigheter la i sine protester vekt på fremstille hastverket ved flyttingen av gravene til Tjøtta og den sterke misnøyen fra befolkningens side. Protestene fra sovjetisk side skapte til tider vanskelige forhold for samarbeidet mellom sovjetiske og norske myndigheter. De skarpe reaksjonene fra den sovjetiske ambassaden på flyttingen av gravene og uenighetene mellom sovjetiske og norske medlemmer i den norsk-sovjetiske gravkommisjonen dannet grunnlaget for de vanskelige forholdene. Protestene fra sovjetisk side kom for sent til at de fikk noen avgjørende betydning for gjennomføringen av flyttingen. Norske militære myndigheter var opptatt av sikkerhetsspørsmålene knyttet til sovjetiske besøk, og lokale myndigheter hadde åpenbart konsentrert seg mest om vedlikeholdet av gravene.

Den norsk-sovjetiske gravkommisjonen ble etablert i 1952 og fikk et begrenset mandat. Norske myndigheter ønsket ikke flere diskusjoner med sovjetiske myndigheter om flytting av graver, og de norske medlemmene i kommisjonen fikk beskjed om å ikke tillate inspeksjoner av tidligere gravsteder i Nord-Norge. Sovjetiske myndigheter ønsket på sin side å bruke kommisjonen til arbeidet med å vedlikeholde gravene der de lå. Året etter at «Operasjon asfalt» var gjen- 
nomført, reiste de sovjetiske medlemmene i gravkommisjonen til Nord-Norge. Samarbeidsproblemer og uenighet om antallet ofre skapte en del vanskeligheter for kommisjonen, men likevel fremhevet de sovjetiske medlemmene at reisen hadde vært nyttig, og det ble enighet om å sette opp minnestøtter på steder der det hadde vært gravlagt et større antall sovjetiske ofre.

Samtidig med flyttingen av gravene i Nord-Norge ble det klart at også gravene i Sør-Norge måtte samles og flyttes til større gravsteder. Gravene her ble ikke flyttet i samme omfang som under «Operasjon asfalt» i Nord-Norge, og flytting av gravene i dette området hadde som regel bakgrunn i helsemessige eller militære forhold. På samme måte som i Nord-Norge var de militære forholdene avgjørende fra begynnelsen av 1950-tallet.

Funn av levninger etter sovjetiske krigsfanger fortsatte i nyere tid. Krigsgravtjenesten ønsket ikke oppmerksomhet omkring seremoniene etter slike funn. En forklaring på dette kan være det kjølige forholdet mellom Norge og Sovjetunionen i begynnelsen av 1980-årene.

På grunn av nytt tilgjengelig kildemateriale, som fangekort, er det i dag mulig å identifisere flere av de sovjetiske ofrene. Ny teknologi har dessuten gjort det enklere for neste generasjon, som også sitter med mange spørsmål 70 år etter, å ta kontakt for å få vite mer om familiemedlemmers eller slektningers skjebne i tysk fangenskap i Norge. Identifikasjonen av de sovjetiske ofrene har gitt mye viktig informasjon til å kartlegge deres skjebne og dødsårsak. Fangekortene viser at en stor andel av fangene døde av sykdom eller svekkelse på grunn av sykdom eller hardt arbeid. Dessverre er en forholdsvis stor andel av fangene ikke oppført med dødsårsak på fangekortet, og dermed har det ikke vært mulig å kartlegge et fullstendig bilde av fangenes skjebne. $\mathrm{Ny}$ informasjon om ofrenes navn og dødssted er viktig for formidlingen av deres historie, og det stiller også norske myndigheter overfor nye utfordringer knyttet til krigskirkegårdene og minnesmerkene. Ved tilfeller der nye navn på ofrene blir identifisert, vil det være naturlig å synliggjøre disse på de ulike minnesmerkene og gravstedene. Av de flere tusen ofrene som døde på havet, er kun et fåtall identifisert, og det gjenstår fremdeles å finne navnelistene over fangene som var om bord $\mathrm{i}$ «Palatia» eller «Rigel» da disse forliste etter angrep.

Flyttingen av jugoslaviske og polske graver skjedde på et senere tidspunkt og fikk ikke den samme massive protesten fra befolkningens side. Det kan være flere årsaker til dette. Antallet graver var færre, og gravene ble flyttet i samråd med myndighetene i det tidligere Jugoslavia og Polen. På 1970-tallet innrømmet tidligere sjef for Krigsgravtjenesten, kaptein Eugen Syvertsen, at arbeidet med flyttingen av utenlandske krigsgraver hadde vært et makabert arbeid. De hadde blitt kritisert fra flere hold om at det hadde tatt altfor lang tid før de for alvor kom i gang med arbeidet. 35000 utenlandske statsborgere 
døde i Norge under krigen, og Syvertsen så det som sin viktigste oppgave å få gitt de avdøde, venn og fiende, sivile og soldater, kjente og ukjente, en grav som var dem verdig. Diskusjonen om de polske krigsgravene viser at dette var et tema som vekket sterke følelser hos de involverte. Norske myndigheter viste at de tok dette på alvor og forsøkte etter beste evne å komme frem til gode løsninger.

En aktiv bruk av minnesteder og monumenter er viktig for bevaringen og videreføringen av minnet om de østeuropeiske krigsfangene i Norge. Det er ikke bare monumentene som er viktige for utviklingen av minnestedet, men også minnemarkeringer, dokumentasjon og forskning, museer, film og arkiv utgjør et viktig grunnlag i formidlingen av krigens fangehistorie nasjonalt og internasjonalt. De norske fangeveteranene og det nasjonale fokuset har preget hovedfortellingen om fangehistorien i Norge og skapt en noe ensidig oppmerksomhet mot den norske siden av krigens fangehistorie i formidlingen. Likevel var det en begynnelse på Falstadskogen minnesteds fornyelse at gjenlevende norske fangeveteraner 60 år etter krigens slutt i 2005 leste opp hilsener fra tidligere serbiske krigsfanger som overlevde fangeoppholdet på Falstad, men det gjenstår fremdeles mye arbeid for å sette minnemarkeringene i en større sammenheng og ikke minst synliggjøre de østeuropeiske krigsfangenes historie både på Falstad og i resten av Norge for den bredere offentligheten. Monumentene i Falstadskogen og deres vektlegging på oppofrelsen, lidelsen og de døde skaper sammen med deres formmessige uttrykk en fortelling om krigens fangehistorie som inviterer til tolkninger der alle nasjonaliteter er inkludert i erindringen. Med bakgrunn i de mange fangekategoriene gir monumentene muligheter for erindring om både militære og sivile ofre av flere nasjonaliteter. Ved å bruke begrepet sammenbrakte erindringer i Falstadskogen representerer monumentene et godt utgangspunkt for en forståelse og formidling av erindringstradisjoner og erindringssteder utover det nasjonale.

Den symbolske og historiske verdien ved krigsgravene til østeuropeiske ofre gir oss svar på hvordan og i hvilken grad andre nasjonaliteter er del av en nasjonal minnekultur i de ulike landene. Eksempler fra Russland, Hviterussland, Kanaløyene og Norge viser en økt vektlegging på tematikken omkring krigsgraver og en større oppmerksomhet enn tidligere på de siviles lidelser. De viser også at det er viktig å ta vare på de lokale initiativene for å vedlikeholde og bevare minnet om ofrene. 


\section{Kilder}

\section{Arkiv}

Bundesarchiv militärarchiv, Freiburg, BA/MA, RW 39.

Carlsen, Trond, privat arkiv, Sandnessjøen.

Falstadsenterets arkiv (Ekne).

Fornyings-, administrasjons- og kirkedepartementet, FAD, Krigsgravtjenesten.

Kirkekontoret i Saltdal, «protokoll for krigskyrkjegarden på Hestbrinken ved Storjord i

Saltdal». Ved sokneprest L.M. Vågdal, Saltdal, udatert 1946.

Kirke- og undervisningsdepartementets arkiv, KUD.

Norges Hjemmefront Museum, NHM, 278. Krigsgravtjenesten, dokumentsamling.

NRK P2, «Kirkegårdskrigen». 08.09.1996.

Public Record Office (London), War Office, PRO, WO.

Riksarkivet (Oslo), Krigsgravtjenesten, RA, RAFA-2018.

Riksarkivet (Oslo), Krigsgravtjenesten, eske 26-35.

Riksarkivet (Oslo), Distriktskommando Nord-Norge (DKN), 316 krigsgraver i NordNorge.

Statsarkivet i Hamar, SAH, Östoppland I.R.5.

Statsarkivet i Kristiansand, SAK, NHM 17 dokumentsamling. Krigsforbrytersaker fra Sørlandet.

Statsarkivet i Trondheim, Helgeland politikammer, Distriktskontoret for krigsgraver i Trondheim og Kirkevergen i Trondheim, krigsgraver, E1, SAT.

Sør-Varanger historielags arkiv, Grenselandsmuseet Kirkenes. Oversikt over sovjetiske krigsgraver i Sør-Varanger under 2. verdenskrig.

Trapitsyn, Igor, privat arkiv (Ekne).

\section{Litteraturliste}

Bodnar, John: Remaking America: Public Memory, Commemoration, and Patriotism in the Twentieth Century. Princeton University Press, New Jersey 1992.

Carleton, Gregory: «Victory in death. Annihilation narratives in Russia today», i History \& Memory, Vol. 22, No. 1. Spring/Summer, 2010.

Carlsen, Trond: Rigel. Norgeshistoriens storste skipsforlis. Eget forlag, Sandnessiøen 2003.

Carr, Gilly: «The slowly healing scars of occupation», i Journal of war and culture studies. Vol 3, nr. 2, 2010.

Christie, Nils: Fangevoktere i konsentrasjonsleire. Pax Forlag, Oslo 1972.

Denkiewicz-Szczepaniak, Emilia: «Polske OT-tvangsarbeidere og krigsfanger i Norge under annen verdenskrig», i Historisk tidsskrift, nr. 2, 1997.

Eidsaune, Thor Helge: «Kirkegårdskrigen 1951», i Årbok for Rana. Mo i Rana 1999.

Eidsaune, Thor Helge: «Kirkegårdskrigen», i Materialisten, nr. 1/2, 2001.

Ellefsen, Arild S.: "Odd Mjelde intervjues om sabotasje og fangeleirenes åpning i 1945», i sartrykk Saltdalsboka, 1980.

Ellefsen, Arild S.: «Russerfanger, repatrieringen og Hestbrinken krigskirkegård», i sartrykk Saltdalsboka, 1986. 
Eriksen, Anne: Det var noe annet under krigen. Pax Forlag, Oslo 1995.

Eriksen, Knut Einar og Pharo, Helge Øystein: Kald krig og internasjonalisering 19491965. Bd. 5. Universitetsforlaget, Oslo 1997.

Eriksen, Knut Einar og Halvorsen, Terje: Norge i krig. Frigjøring. Bd. 8. Aschehoug \& Co., Oslo 1987.

Fjermeros, Halvor: Med lik i lasten. Operasjon Asfalt - de sovjetiske massegravenes skjebne i Norge. Spartacus, Oslo 2013.

Gorter, Anastasia A, Waling T. Gorter og Michael N. Suprun: Frigjøringen av Øst-Finnmark 1944-45. Arkhangelsk Pomor, Arkhangelsk 2005.

Holtsmark, Sven G.: Norge og Sovjetunionen 1917-1955. Institutt for forsvarsstudier og Det russiske vitenskapsakademi, Oslo 1995.

Jovanovic, Cveja: Blodveien. Beograd 1988.

Kovačević, Ostoja: En times frihet. Gyldendal, Oslo 1959.

Knutsen, Bjørn: Erindringen omkring de østeuropeiske krigsfangene i Norge - En drøfting av realhistorie versus erindringshistorie med vekt på historisk bevissthet og kollektiv erindring. Hovedoppgave i historie, Bergen 2001.

Kverndokk, Kyrre: De kjempet, de falt, de gav oss alt - om den rituelle bruken av norkke krigsminnesmerker. Hovedoppgave i folkloristikk, Institutt for kulturstudier. Oslo 2000.

Merridale, Catherine: Ivan's war. Faber and Faber, London 2006.

Mezentsev, Feodor: I konsentrasjonsleire bak polarsirkelen. Upublisert manus, 1997. Oversatt fra russisk av Asbjørn Hortman.

Mladenović, Ljubo: Beisfordtragedien. Grøndahl \& Søn Forlag A/S, Oslo 1989.

Nora, Pierre (red.): Les lieux de mémoire. Columbia University Press, New York 1984-1992.

Norsk Retstidende 1945-1949. Agder lagmannsretts dom av 14.06.1947.

Nøkleby, Berit: Krigsforbrytelser. Brudd på krigens lov i Norge 1940-45. Pax Forlag, Oslo 2004.

Ollila, Anne: «Introduction: History as Memory and Memory as History» i Studia Historica 61, 1999.

Olsen, Bjørn og Bjørn Hafsten: Flyalarm: luftkrigen over Norge 1935-1945. Sem \& Stenersen, Oslo. 2005.

Otto, Reinhard: «Cemeteries of Soviet prisoners of war in Norway» i Historisk Tidsskrift, nr. 4, 2011.

Parelius, Nils: «Tilintetgjørelsesleirene for jugoslaviske fanger i Nord-Norge. Spesielt om leiren i Botn», i sartrykk Saltdalsboka, 1984.

Riste, Olav: «London-regjeringa» Norge i krigsalliansen 1940-1945. Bd. 2. Det Norske Samlaget, Oslo 1979.

Rønnebu Lund, Gaute: En ualminnelig vemmelig sak: Opinionens reaksjoner på Operasjon Asfalt i 1951. Masteroppgave i historie. Universitetet i Nordland, 2014.

Scherrer, Jutta: «Siegesmythod versus Vergangenheitsaufarbeitung», i Mythen der Nationen. Bd. 2. Deutsches Historisches Museum, Berlin 2004.

Sellevold, Berit J.: «Om retningslinjer for håndtering og forvaltning av skjelett- og gravfunn fra nyere tid». NIKU Rapport 32. Rapport til Riksantikvaren, Oslo 2009.

Snyder, Timothy: Dødsmarkene: Europa mellom Hitler og Stalin. Gyldendal, Oslo 2012. 
Soleim, Marianne Neerland: Sovjetiske krigsfanger i Norge - Antall, organisering og repatriering. Avhandling i historie, Universitetet i Tromsø, 2004.

Stokke, Michael: Sovjetiske og franske sivile tvangsarbeidere i Norge 1942-1945. Masteroppgave i historie. Universitetet i Bergen, 2008.

St.prp. nr. 141 (1968-69). Om bevilgning under kap. 226. Krigsgravtjenesten, ny post 28. Ilandføring og gravlegging av omkomne krigsfanger. Kirke- og undervisningsdepartementet.

Streit, Christian: Keine Kameraden. Die Wehrmacht und die sowjetischen Kriegsgefangenen 1941-1945. Verlag J.H.W Dietz Nachf., Bonn 1997.

Syvertsen, Eugen: «Fortegnelse over sovjetiske krigskirkegårder og krigsgraver i Norge. Samt fortegnelse over navngitte sovjetiske statsborgere gravlagt i Norge under krigen 1941-1945». Kirke- og undervisningsdepartementet, Krigsgravtjenesten, Oslo 1979.

Sør-Varanger historielag: Sør-Varanger under 2. verdenskrig, arena i stormaktskonflikt. Historielaget, Kirkenes, 1997.

Thorheim, Eiliv: «Krigsgraver i Norge». Upublisert notat, Krigsgravtjenesten, Oslo 2002.

Ulateig, Egil: Hjem til Stalin. Skjebnen til 83000 russiske krigsfanger i Norge 1945. Cappelen, Oslo 1985.

Vinsrygg, Laura: «Krigskyrkjegarden», i Saltdalsboka 1996.

Wara, Kalle: Det tiende slaget. Falken Forlag A/S, Oslo 2004.

Wertsch, James V.: Voices of Collective Remembering. Cambridge University Press, Cambridge 2002. https://doi.org/10.1017/CBO9780511613715

Westerlund, Lars (red.): Prisoners of War and Internees. Oy Nord Print Ab, Helsinki 2008. Young, James E: The Texture of Memory. Yale University Press, New Haven/London 1993.

\section{Aviser}

Adresseavisen, 13.06.1945

Aftenposten, 05.06.1956

Arbeider-Avisa, 15.08.1945 og 29.10.1984

Dagbladet, 04.10.1941 og 24.05.2010

Dag og Tid, 24.02.2000

Friheten, 08.10, 15.10 og 07.11.1951

Gudbrandsdølen Dagningen, 21.09.2010 og 10.05.2012

Helgeland, 25.07.1945, 18.09, 09.10 og 03.11.1951

Helgelands Blad, udatert 1953 og 29.04.2011

Nidaros, 29.10. 1952

Nordland Arbeiderblad, juni (udatert), 14.06, 28.08, 15.09, 27.09, 29.09, 02.10 og 09.10.1951

Nordlands Avis, 11.12.1951 og 10.07.1953

Nordlands Folkeblad, 28.02.1947, 21.09, 28.09 og 5.10.1951

Stavanger Aftenblad, 22.09.1997

Sør-Varanger Arbeiderblad, udatert, november 1949

Telemarksavisa, 28.04.2006

Tromsø, 23.06.1945

Verdens Gang, 5.10 og 03.11.1951 


\section{Intervju}

Dvortsov, Nikolays datter Tatjana Nikolayevna Dvortsova. Intervju utført av Marina Panikar, 2010.

Jovanović Dragan, Serbia, 2010.

Kalnin, Nikolayevich, Vladimir. Intervju utført av Marina Panikar, 2010.

Åkvik, Ingolf, 2010.

Brev

Brev fra Viktor Oleksandrovich Petrasjevski til forfatteren, 06.06.2001, oversatt fra russisk til norsk av Viktor Igorovitsj.

\section{Nettsider}

http://janss.dk/palatia.php. (Lest 12.05.2014)

http://jersey.com/english/discoverjersey/occupationtoliberation/memorial/pages/ default.aspx. (Lest 10.10.2013)

http://norskekirkebygg.origo.no/-/bulletin/show/751225_joerstadmoen-krigskirkegaard. (Lest 01.10.2015)

http://obdmemorial.ru/memorial/fullimage?id=73120461\&id1=c42fe14e68e-

02b1342268ad8163b5d8\&path =Z/010/058-0018003-1609/00000291.jpg (Lest 04.04.2013)

http://www.nrk.no/nordland/fant-farens-grav-etter-70-ar-1.8293162. (Lest 28.08.2012)

http://www.sva.no/index.php?page=vis_nyhet\&NyhetID=2476. (Lest 08.06.2015) www.obd-memorial.ru. (Lest 10.10.2014) Fangenr. 16774, Nikolaj Jefimovitsj

Belousov, registrert i databasen.

\section{Databaser}

www.obd-memorial.ru. (lest 02.05.2012)

www.krigsgraver.no.

\section{Annet}

Falstad museum utstilling 1995-2004, åpnet 7. mai 1995, utformet av scenograf Worm Winther. 